\title{
Correlations between morphological fruit types, fruit and seed colors, and functional groups
}

\author{
Nelson Ramírez ${ }^{1 *(\infty)}$,Yeni Barrios ${ }^{2}$ \& Herbert Briceño ${ }^{1}$ \\ ${ }^{1}$ Universidad Central de Venezuela, Facultad de Ciencias, Instituto de Biología Experimental, Centro de \\ Botánica Tropical, Caracas, Venezuela. \\ ${ }^{2}$ Universidad de Los Andes, Facultad de Ciencias, Instituto Jardín Botánico de Mérida, Mérida, Venezuela. \\ *Corresponding author: nramirez220252@gmail.com
}

RAMÍREZ, N., BARRIOS, Y., BRICEÑO, H. Correlations between morphological fruit types, fruit and seed colors, and functional groups. Biota Neotropica 21(4): e20211238. https://doi.org/10.1590/1676-0611-BN-2021-1238

\begin{abstract}
The associations between morphological fruit types, fruit and seed colors, and functional plant traits: life forms, epiphytism, physiology, nutritional relationships, fruit phenology, and successional stage, were determined for 1,139 plant species from contrasting plant communities. Texture and dehiscence were closely related. Dehiscence is largely associated with dry tissues; indehiscence, however, is an attribute of both dry and fleshy fruits. The number of morphological fruit types was 28 or 55 for Gray's and Spjut's classifications, respectively. Fruits were predominantly dark in color (brown, purple-black, black or green), whilst seeds had both dark and light colors (brown, beige, or black). The most representative associations were mainly found between the more abundant fruit types and the colors most common. Asymmetries in the level of specialization, whereby less common fruit and seed colors tended to be associated with the most common fruit types, were also found. Fleshy fruits showed more variation as regards their coloration, and only drupes and berries showed a tendency towards a specific color: purple-black. The relationships among fruit type and color, seed color, and functional plant traits revealed the following trends: trees produced both fleshy and dry fruits; shrubs produced fleshy fruits; and herbaceous species, dry fruits. Woody species tended to have dark or bright colors, depending on their seed dispersal mechanisms and phylogenetic relations. Epiphytes were associated with dry-dehiscent fruits and brown seeds, and parasitic-hemiparasitic species had predominantly fleshy-indehiscent fruits. Pioneer species were more likely to have dry fruits, whereas fleshy fruits tended to be more frequent in late successional stage species. The C4 species, mostly herbs, had mainly one-seeded dry fruits, but multi-seeded fruits in succulent-CAM species showed morphologically diverse fruit types. Unripe and ripe fruits showed seasonal changes, especially during the rainy-dry transition period for the most abundant morphological fruit types, dry fruits during the dry period and fleshy fruited species was positively associated with the rainy season. All these trends are discussed with regard to their environmental significance and the relationships between fruit morphology, colors and functional groups. .
\end{abstract}

Keywords: Morphological fruit type; fruit color; fruit phenology; functional group; plant life form; successional stage.

\section{Correlaciones entre tipos morfológicos de frutos, colores de frutos y semillas y grupos funcionales}

\footnotetext{
Resumen: Las asociaciones entre tipos morfológicos de frutos, colores de frutos y semillas y los grupos funcionales de las plantas: formas de vida, epifitismo, fisiología, relaciones nutricionales, fenología de frutos y estado sucesional fueron determinados para 1139 especies de plantas de comunidades contrastantes. La textura y dehiscencia estaban muy relacionadas. Dehiscencia está estrechamente asociada con tejidos secos, pero indehiscencia es un atributo de frutos secos y carnosos. El número de tipos morfológicos de frutos fue 28 y 55 para la clasificación de Gray y Spjut respectivamente. Los frutos fueron predominantemente de colores oscuros (marrón, negro-purpura, negro o verdes), mientras que las semillas tenían colores claros y oscuros (marrón, beige o negro). Las asociaciones más representativas fueron principalmente encontradas entre los tipos de frutos más abundantes y los colores más comunes. También se encontraron asimetrías en los niveles de especialización, donde los colores menos comunes de frutos y semillas estuvieron asociados con los tipos de frutos más comunes. Los frutos carnosos mostraron más variación en su coloración, y solo las drupas y bayas tendieron a colores específicos como negro-purpura. Las relaciones entre tipo de fruto y color, color semilla y rasgos funcionales de las plantas revelaron las siguientes tendencias: arboles producen frutos secos y carnosos; arbustos frutos carnosos y hierbas producen frutos secos. Las especies leñosas tendieron a tener colores oscuros y brillantes, relacionados con su mecanismo de dispersión y filogenia. Epifitas estuvieron asociadas con frutos secos dehiscentes y semillas marrones, y las especies
} 
Ramírez, N. et al.

parásitas-hemiparásitas tenían predominantemente frutos carnosos indehiscentes. Las especies pioneras tenían comúnmente frutos secos, mientras que los frutos carnosos tendieron a ser más frecuentes en especies de estados sucesionales tardíos. Las especies C4, principalmente hierbas, tenían frutos secos con una semilla, mientras que frutos polispermos en especies CAM mostraron diversos tipos de frutos. La fenología de frutos maduros e inmaduros mostro cambios estacionales para los más abundantes tipos morfológicos, especialmente durante el periodo de transición lluvia-sequia, frutos secos en el periodo seco y frutos carnosos durante el periodo lluvioso. Todas estas tendencias son discutidas con relación a las características ambientales y de acuerdo con las relaciones entre tipos morfológicos de frutos, colores y grupos funcionales.

Palabras claves: Tipo morfológico fruto; color fruto; estado sucesional; fenología fruto; forma de vida; grupo funcional.

\section{Introduction}

Fruits represent a crucial phase of angiosperm life cycle. By definition, a fruit is the mature ovary which, in the majority of cases, contains the seeds (Font Quer 2001, Simpson 2019), although other definitions include accessory flower structures that accompany the developed ovary (Spjut 2004). Fruits and flowers have evolved together whereby the ovules were covered and enclosed by the carpelar leaves, and subsequently the carpels transformed into the pericarps of the fruit at maturity (Taylor and Kirchner 1996, Spjut 2004, Vialette-Guiraud and Scutt 2009). A fruit, then, may be initially considered as a structure that protects an ensemble of seeds in which the carpels and pericarps shield the ovules and seeds against extreme climatic conditions, herbivory and predispersal seed predation, during flowering, pollination, unripe fruit development and ripe fruit phases (Chambers and MacMahon 1994). Accordingly, fruits are plant organs with multiple associations.

Fruit morphology is described according to two basic traits: pericarp texture and dehiscence. Many floral characteristics such as gynoecium structure and the number of flowers determine morphological fruit type, including in many cases accessory flower structures and inflorescences that accompany fruits. The multiplicity of possible combinations of fruit parts has led to the identification of a large and complicated variety of fruit types, which have been classified in different way according to the criteria used. Two main systems of fruit classification are currently considered in comparative studies: 1) the traditional fruit classification set out by Gray (1877), based mainly on the texture of the pericarp (fleshy or dry), and the pattern of dehiscence or indehiscence together with gynoecium structure, and 2) the systematic fruit type treatment given by Spjut (1994) based on pericarp and antocarp (ripened ovary with attached floral parts, persistent or accrescent) types, in addition to gynoecium structure. Both classification systems provide valuable evidence for evolutionary and ecological trends in fruit morphology. However, they may offer different interpretations of the possible ecological relationships among morphological fruit types, fruit and seed colors, and the associations of these with functional groups.

Variations in the characteristics of fruits are frequently related to specific flower morphology and may be phylogenetically influenced. About $28 \%$ of 281 angiosperm families produce fleshy fruits, $20 \%$ contain species with either fleshy or dry fruits "mixed families" and $53 \%$ produce only dry fruits (Fleming 1991). However, morphological fruit types of certain clades are, in many cases, modified by ecological factors and by the potential relationships between fruit morphology and functional groups, such as life form, carbon metabolism pathway, and epiphytism. Regarding life form, herbaceous species tend to bear dry fruits, and woody species (shrubs and trees) fleshy fruits (Herrera 1984, Willson et al. 1989, French 1991, Possete et al. 2015, Wotton \&
McAlpine 2015); vines may exhibit variation according to forest type (Willson et al. 1989, Possete et al. 2015). Fruit types, and fruit and seed colors are also representative of successional stages, with dry fruits being more abundant in open vegetation communities (e.g. Arbeláez \& Parrado-Rosselli 2005) and fleshy fruits in forests (Carpenter et al. 2003, Chen et al. 2004, Buitrón-Jurado \& Ramírez 2014, Hilje et al. 2015). In addition, the frequencies of fruit types may differ between vegetation strata (Yamamoto et al. 2007) and reproductive phenology: dry fruits are often produced during the dry season and fleshy fruits during the rainy season (Wheelwright \& Janson 1985, Jordano 1993, Bulhão \& Figueiredo 2002, Bentos et al. 2008). In this context, many plant species synchronize fruiting and dispersal with the onset of the rainy season to maximize seedling development and establishment (Oliveira 1998).

The color of fruits and seeds is an attribute frequently associated with advertising (Ridley 1930, Stiles 1982, Knight \& Siegfried 1983, Wheelwright \& Janson 1985, Cazetta et al. 2009). Colorful fruits have different functions: to attract dispersal agents; reveal fruit localization; and give a visual indication of fruit ripeness (Ridley 1930). Fruit color may have two other functions: to be conspicuous and attractive (Wheelwright \& Janson 1985). The function most often ascribed to the colors of bird-dispersed fruit is the former: their enhanced visibility increases their chances of being seen by potential seed dispersers. Bright colors are thus the "flag" (Ridley 1930, Stiles 1982) that catches the birds' attention. If conspicuousness were the sole reason for color displays in bird-dispersed fruits, however, we would expect comparable fruit displays under similar visibility conditions. In addition to signaling location, the color of a fruit may convey information about its quality that would influence a bird's choosing of that fruit (Wheelwright \& Janson 1985, Schaefer \& Schmidt 2004). However, fruit and seed colors may have functions other than that of advertising. For example, dark colors (blue, black, and brown) may absorb more radiation in the visible spectrum than pale colors (white, yellow, orange and red) (Wheelwright \& Janson 1985). Fruit colors may also affect the thermal regime of developing fruits and their enclosed seeds; be a side-effect of secondary chemical production that protects the fruit from predispersal damage; or have other physiological functions (Willson et al. 1989). Green and developing fruits may also contribute a major proportion of their own photosynthate (Bazzaz et al. 1979). Light-colored seeds have also been significantly associated with rapid germination times (Stringam et al. 1974, Daun \& DeClercq 1988, Thompson 1993, Debeaujon et al. 2000). Dark colors, such as black, brown and blue, could absorb greater amounts of solar radiation, which might increase their temperature and thus accelerate metabolism and ripening speed (Janzen 1983, Wheelwright \& Janson 1985), as well as providing a protective function due to their high anthocyanin content (Schaefer 
2011). Furthermore, fruit color can be related to morphological fruit types: drupes and berries are often colorful, whereas loculicidal capsules tend to be brown (Knight \& Siegfried 1983, López \& Ramírez 1989, Ibarra-Manríquez \& Cornejo-Tenorio 2010). Therefore, fruit and seed color functions are indicative of both biotic and abiotic interactions, for example, attracting or avoiding animals.

Morphology and color are significant attributes of fruits and seeds and can be associated with diverse functions of the plant species life cycle. Fruit morphology and fruit and seed colors may either complement, or be independent from, each other. Morphological fruit type, consumer type and fruit size are all dependent on each other, whereas fruit color is related to both fruit size and consumer type, which themselves act independently from each other (Knight \& Siegfried 1983). The great diversity of morphological fruit types, and fruit and seed colors, and their multiple combinations, are not necessarily independent of morphological, physiological and ecological plant attributes. Such relationships, although still poorly understood, must be line with those factors that maximize plant fitness, and will thus vary according to life history characteristics. Hence, morphological fruit types, and fruit and seed colors must be traits that can be related to plant functional groups. Phenotypic integration among traits has the potential to influence ecological communities through direct and indirect linkages within networks of interacting species. Associations among traits could thus potentially impact how the combined effects of direct and indirect selection on interactions shape the trajectories of coevolution under different environmental conditions (Assis et al. 2020).

We suggest that morphological fruit types and the colors associated with them should be analyzed ecologically, irrespective of dispersal syndromes and natural reproductive efficiency. This kind of analysis has not yet been attempted, and could enable us to establish whether morphological fruit types, and fruit and seed colors, represent ecological attributes that can be associated with particular functional groups, such as life form, epiphytism, carbon metabolism pathway, nutritional relationships, seasonality of fruit phenology, and the successional stage of the plant species. Morphological fruit types deserve their own ecological analysis in order to determine trends and relationships between fruit morphology, fruit and seed colors, and plant functional groups. In this context, we posed the following questions: 1- What kinds of associations occur among morphological fruit types, fruit colors and seed colors? 2- Are morphological, ecological and physiological functional groups of plant species related to the morphological fruit types of Gray (1877) and Spjut (1994), and fruit and seed colors? 3What are the functional groups that best explain fruit morphology and fruit and seed colors?

\section{Material and Methods}

\section{Study areas}

The plant communities we surveyed were extremely varied in their vegetation structure and complexity, and the selection we made also took account of climatic factors (temperature and precipitation) and altitude. Mean annual temperatures and mean annual precipitations ranged from 2.8 to $28.7^{\circ} \mathrm{C}$ and from 330.5 to $2428.4 \mathrm{~mm}$ of rain, respectively, across the plant communities studied, and included communities at sea level to close to $4,000 \mathrm{~m}$ (Table 1). Plant species were surveyed from 27 sites in Venezuela in ten geographic areas, and included plant communities belonging to five vegetation types: 1) dry forests, 2) meadows, 3) shrublands, 4) wet forests, and 5) wetlands. Each vegetation type included a large variety of plant communities. Dry forests were comprised of secondary dry forest, the forest-savanna ecotone, gallery forest, and a riparian dry forest, with a temporary river during the rainy season. Wet forests included cloud forest, dwarf cloud forest, and riparian wet forest. Meadow vegetation was predominantly herbaceous and included savanna, littoral meadow, psammophilous meadow, and disturbed grassland. Shrublands were represented by mesothermic, xerophytic, and high mountain shrublands, a littoral shrubland containing a mix of shrubs and herbs (Atoll) and bushland. Wetlands are permanently flooded plant communities, and were comprised of broad-leaved meadow, palm swamp, and mangrove communities. Three disturbed communities with different levels and times of disturbance were also surveyed: 1) a bushland several years after disturbance (bushland is a term for land which supports remnant vegetation or land which is disturbed but still retains a predominance of the original flora and structure [Draper \& Richards 2009]), 2) a fallow, secondary savanna represented by an abandoned area of cultivated, uncultivated, and disturbed grassland, and 3) an area of savanna annually disturbed by fire, grazing and machinery (mainly agricultural).

\section{Plant species selection and taxonomic aspects.}

Plant species were selected in such a way as to maximize the number of plant families, genera and species studied. As noted above, plant species from 27 plant communities were surveyed. In addition, 30 plant species from other sites in Venezuela were considered in the analyses, including some plant species from previous studies (see Table 1). A previous analysis of the association between taxonomy and plant species composition (N. Ramírez and H. Briceño, in preparation) showed that three orders (Fabales, Malphigiales and Poales) and one family, Fabaceae, were dominant in the species examined. Specifically, the frequency of dry fruits was higher than that of fleshy fruits and significantly correlated with the Fabales and Poales orders, and the Fabaceae family. In addition, indehiscent fruits were significantly more abundant than dehiscent fruits in the sample examined, and correlated with Poales species. The frequencies of simple (indehiscent) fruits, originating from one flower, and rhexocarpic (dehiscent) fruits were also significantly high in the sample studied. However, only rhexocarpic fruits were significantly correlated with Fabales species.

\section{Morphological fruit types}

Fruits were initially classified with regards to their texture (fleshy and dry fruit types) and dehiscence (dehiscent and indehiscent fruit types). After this first classification they were grouped according to two systems: 1- The traditional classification set out by Gray (1877), and 2- The systematic treatment given by Spjut (1994). Gray's (1877) system is based on the texture of the pericarp (fleshy or dry); the pattern of dehiscence or indehiscence; the shape and size of the fruit; carpel and ovule number; fruit that develop from one flower; fruit that develop from a single carpel or fused carpels (single fruit); those that develop from several separate carpels of a single gynoecium (aggregate fruit); and those that develop from more than one flower (multiple fruit or infrutescence). Spjut's (1994) classification system is based on the presence of a pericarp (ripened ovary without any attached floral 
parts) or antocarp (ripened ovary with attached floral parts, either persistent or accrescent); gynoecial structure (apocarpous, syncarpous or schizocarpous); and the distinction between fruits that develop from one flower, and those that develop from more than one flower. In addition, compound (aggregate) gynoecia are recognized when they become united to form compound fruit (from more than one flower). This classification system includes 95 different fruit types, primarily grouped into two large categories: spermatocarpia (naked seeds), and eucarpia (covered seeds). The second of these contains five sub-categories: simple fruits (fruit not dispersed from a pericarpium, developing from one flower); rhexocarpic fruits (fruit dispersed by the opening of the pericarp); schizocarpic fruits (fruitlets derived from a compound pistil separating into its carpellary constituents); multiple fruits (a single flower producing multiple fruitlets, apocarps); and compound fruits (fruits derived from more than one flower).

\section{Fruit and seed colors}

Fruits and seeds were characterized according to their color at maturity. Fruit and seed color generally refers to the external surface, although the color of the internal surface of some dehiscent fruit was also considered when it differed from that of the external surface. We grouped the different tonalities of the fruit and seed colors we observed into broader color categories. Thus, dark-brown, light-brown, and reddish-brown tonalities were all included in the category "brown"; light yellow was described as "yellow" ; and dark-green, brownishgreen, and jade-green tonalities were all considered as "green". The category "purple-black" unified fruits and seeds with dark and very dark purple tonalities, and those close to black that were difficult to fit into other color categories. The categories were then sorted into three large groups: 1- dark colors (black, brown, green, blue, purpleblack), 2- bright colors (orange, pink, red, yellow), and 3- light colors (beige, white). Fruits and seeds were also classified as single-colored or bi-colored according to the number of different colors on a single fruit and/or seed at maturity. In the case of dehiscent fruits, bi-colored fruits refer to the different colors on the internal and external surfaces of the pericarp.

\section{Functional groups}

\subsection{Life forms and succulence}

Plant life forms were determined using criteria previously described (Ramírez \& Herrera 2017). Plant life forms were established according to their structure, height, woodiness, ramification type, and life span, into five categories: tree, shrub, liana, perennial herb, and annual herb. As a first grouping, plant species were separated into perennial and short-lived (or annual) species. Short-lived species were herbaceous plants in which more than $80 \%$ of the individuals surveyed died over the two year observation period in the permanent plots surveyed (minimum of ten individuals per species per plot). Perennial species were those species with an extended life cycle and multiple reproductive events. This latter condition included monocarpic perennial species as they are long-lived. We did not consider plant distribution across the vertical profile of the communities, thus epiphytic species were included as herbaceous species (short-lived or perennial) depending on their life span. Some parasitic epiphytes (e.g. Phthirusa spp.) were included as climbing species because their branches creep along the host plant.
Species were also classified as succulents (having specialized fleshy tissue in a plant organ for the conservation of water) and non-succulents.

\subsection{Nutritional relationships}

Plant species were classified as regards how they obtain their nourishment, into three categories: 1- Autotrophy, plants that synthesize their own food, 2- hemiparasite and parasite, plants that partially or wholly obtain their nourishment from other living plants, and 3insectivores, plants that partially obtain their nourishment from insects. The conditions of parasitism, hemiparasitism, and insectivory were mostly inferred by the habit of the plant, and / or whether it had modified, leaves, or roots, and then confirmed with systematic studies (Judd et al. 1999, Smith at al. 2004). In some cases, information about nutritional relationships was taken from previous studies (Ramírez et al. 2012).

\subsection{Carbon metabolism pathway}

Plant species were classified according to which of the three main carbon assimilation pathways, $\mathrm{C}_{3}, \mathrm{C}_{4}$ or CAM (Crassulacean acid metabolism) they employ. Information about the carbon metabolism pathways of plant species was taken from previous studies (Ramírez \& Briceño 2015, Ramírez \& Herrera 2017).

\subsection{Epiphytism}

Plant species were classified according to their substrate type as: epiphytes, when one plant grows on another host plant; or non-epiphytes (terrestrial), when the plant species grows directly in the soil.

\subsection{Successional condition}

Plant species were also grouped with regard to their successional stage in a community as: 1- late seral or climax species, and 2- pioneer species. Late seral species were found growing in natural or undisturbed areas, whereas pioneers were found growing in disturbed areas, impacted mainly from fires and / or agricultural machinery.

\subsection{Fruit phenology}

Lastly, the plant species were classified according to their unripe (fruit development times), and ripe fruit phenology using data from previous studies (Castillo 1977, Sobrevila 1978, Colonnello 1980, López 1981, Tuges 1982, Sobrevila et al. 1983, Gómez 1984, Berry 1984, Ramírez \& Brito 1987, Ramírez et al. 1988, Hokche \& Ramírez 1990, Seres \& Ramírez 1993, Ruiz-Zapata 1994, Guzmán 1995, LLamozaSolórzano 1998, Xena et al. 1999, Castro-Laportte \& Ruíz-Zapata 2000, Lemus-Jiménez \& Ramírez 2002, Nassar \& Ramírez 2004, Herrera \& Nassar 2009, Ramírez 2009, Ramírez \& Briceño 2011, López \& Ramírez 2013). For statistical purposes, discrete climatic periods when fruit phenology was observed were established for each plant species as follows: rainy season, dry season, and rainy-dry transition period. Plant species fruiting during the transition period included plant species that also fruited in the rainy and/or dry seasons as well as those that fruited exclusively during the transition period.

\section{Data Analysis}

Independence test was used to determine whether fruit structural types: fruit texture (dry or fleshy), and fruit dehiscence (dehiscent or indehiscent), differed from each other according to the functional groups identified (life-form, successional stage, nutritional relationship, 
carbon metabolism pathway, plant succulence, epiphytism, unripe fruit phenology, and ripe fruit phenology). The level of dependence and interactions between these two categories were determined using a log-linear analysis of frequency: a method of interpreting the data in cross-tabulation tables (Statsoft 2007). When the log-linear analysis of frequency was significant, the residual frequencies, i.e. the observed minus the expected frequencies, were estimated for each cell of the two factor comparison table, and then standardized and tested for significance. This analysis enabled us to establish which pairs of variables deviated significantly from expected values (Legendre \& Legendre 1993) and thus contributed more to the association. Significant and positive residuals indicated a strong association between the categories, and significant and negative residuals, an unusual occurrence. The level of dependence and interactions using log-linear analysis of frequency was also employed for analyzing the relationships between fruit texture and dehiscence.

The associations between pairs of fruit attributes: morphological fruit types $v s$. fruit and seed color, were analyzed using bipartite graphs (Dormann et al. 2008, R core Team 2015), which graphically represent a two mode network consisting of two sets of nodes with interactions (associations) between (but not within) them (Bascompte \& Jordano 2007). We determined the following descriptors when analyzing fruit morphology, fruit color and seed color associations: 1- the number of morphological fruit types according to Gray's classification, 2- the number of morphological fruit types according to Spjut's classification, 3- the number of fruit color classes, 4- the number of seed color classes, 5- the total number of potential associations, 6- the total number of recorded associations, and 7- the frequency of the number of associations (i.e. 1, $2,3, \ldots \ldots n$ ) for each pair of comparisons, namely, fruit color-Gray's classification; fruit color-Spjut's classification; seed color-Gray's classification; seed color-Spjut's classification; and fruit-seed color. We also calculated the mean number of associations per fruit type according to Gray and Spjut, fruit color class, and seed color class. Connectance, defined here as the percentage of associations with respect to the total possible, in analogy with the measure used in interaction webs (Jordano 1987), was also determined for each pair of items analyzed.

\section{Results}

\section{Morphological fruit types}

\subsection{The texture and dehiscence of fruit types}

We characterized the fruits of 1,139 plant species according to structural type (Table 1). The categories of fruit texture and dehiscence were found to be statistically dependent on each other $\left(\mathrm{df}=1, \chi^{2}=\right.$ 268.01; $\mathrm{P}=0.0$ ) and all residuals were significant at $\mathrm{P}<0.05$. Overall, there were twice the number of species with dry fruits $(\mathrm{N}=790 ; 69.4 \%)$ than fleshy fruits $(\mathrm{N}=349 ; 30.6 \%)$ in the sample. In contrast, the number of species with indehiscent fruits $(\mathrm{N}=640 ; 56.2 \%)$ was only slightly higher than that of those with dehiscent fruits ( $\mathrm{N}=499 ; 43.8 \%)$. Similarly, the number of species with dry-dehiscent fruits, $(\mathrm{N}=472$; $59.7 \%$ ) was only slightly higher than that of those with dry-indehiscent fruits ( $\mathrm{N}=321,40.3 \%$ ). In contrast, fleshy fruits were mostly indehiscent $(\mathrm{N}=322,92.3 \%)$, and only a few $(\mathrm{N}=27,7.7 \%)$ species with dehiscent fruits were recorded.

\subsection{Frequencies of morphological fruit types}

The number and frequency of each morphological fruit type according to Gray and Spjut are given in Appendix S1. The sample examined contains a large diversity of fruit types (Figure 1). We recorded 28 morphological fruit types according to Gray's classification (type I fruits) and 55 following Spjut (type II fruits). The most abundant morphological fruit types $(\mathrm{N} \geq 10$ and $\geq 10 \%)$ were type I fruits: loculicidal capsule $(\mathrm{N}=165,14.5 \%)$, berry $(\mathrm{N}=165,14.5 \%)$, drupe $(\mathrm{N}=$ $131,11.5 \%)$, and achene $(\mathrm{N}=125,11.0 \%)$, and type II fruits: loculicidal capsule $(\mathrm{N}=161,14.1 \%)$ and bacca $(\mathrm{N}=122,10.7 \%)$. Comparisons between the fruit classification systems (I and II) revealed many coincidences as regards nomenclature and the general morphology of many fruit types (i.e. berry, loculicidal capsule, drupe, septicidal capsule, legume, and silique). Nevertheless, type I fruits departed from type II fruits in some cases (Figure S1). For example, achenes and schizocarps in Gray's classification correspond to a variety of fruit types following Spjut.

\section{Fruit and seed colors}

Eleven single-colored and seven bi-colored categories were observed for the fruits and seeds studied. The single-colored categories identified were: beige, black, blue, brown, green, orange, pink, red, white, yellow, and purple-black. Black was the most common color of the bi-colored fruits and seeds, and brown, white, yellow and red occurred in the following combinations: white+black, black+yellow, and green+red in fruits, and black+red, black+yellow, brown+white, brown+yellow, and white+black in seeds. Many fleshy indehiscent and dehiscent fruits were bi-colored. For example, the white+black drupes of Tournefourtia volubilis, and the fleshy, dehiscent fruits of Capparis flexuosa, with their external green and internal red surfaces contrasting with the black and white seed colors. Bi-colored patterns were mainly found on the seed coats, for example the red+black seed coat and aril of Erythrina mitis, and the black seed coat and yellow aril of Connarus venezuelensis.

The number and frequencies of the fruit and seed colors identified are given in Table 2 . Fruits $(\mathrm{N} \geq 10$ and $\geq 10 \%)$ were mostly brown $(\mathrm{N}=$ $644,56.5 \%)$ followed by purple-black $(\mathrm{N}=125,11.0 \%)$ and black $(\mathrm{N}=$ $95,8.3 \%)$. Seeds tended to be brown ( $\mathrm{N}=666,58.5 \%)$, beige $(\mathrm{N}=185$, $16.4 \%)$ or black $(\mathrm{N}=136,11.9 \%)$. The lowest frequencies of singlecolored fruits / seeds were bright (orange and pink), light (white and beige) and dark (blue) fruits (0.7-1.5\%), and dark (green and blue) and bright (orange and red) seeds (0.2-1.8\%). All categories of bi-colored fruits / seeds occurred at the same or lower frequencies than categories of single-colored fruits / seeds. The number of bi-colored categories of fruits and seeds also differed with fruits showing three different bicolored combinations, and seeds five different combinations.

\section{Associations between fruit and seed colors}

The fruit and seed color comparison analysis revealed large variations in the colors of the fruits and seeds (Figure 2), as well as within-species differences between fruit and seed color, except that plants with brown fruits tended to produce brown seeds $(\mathrm{N}=470$, $72.9 \%$ ). Nevertheless, species with brown fruits were also associated with nine other seed colors, the most abundant and frequent $(\mathrm{N} \geq 10$ and $\geq 10 \%$ ) being black and beige (Appendix S2). Brown was also the most common seed color for purple-black, yellow, red, and green fruits. In 


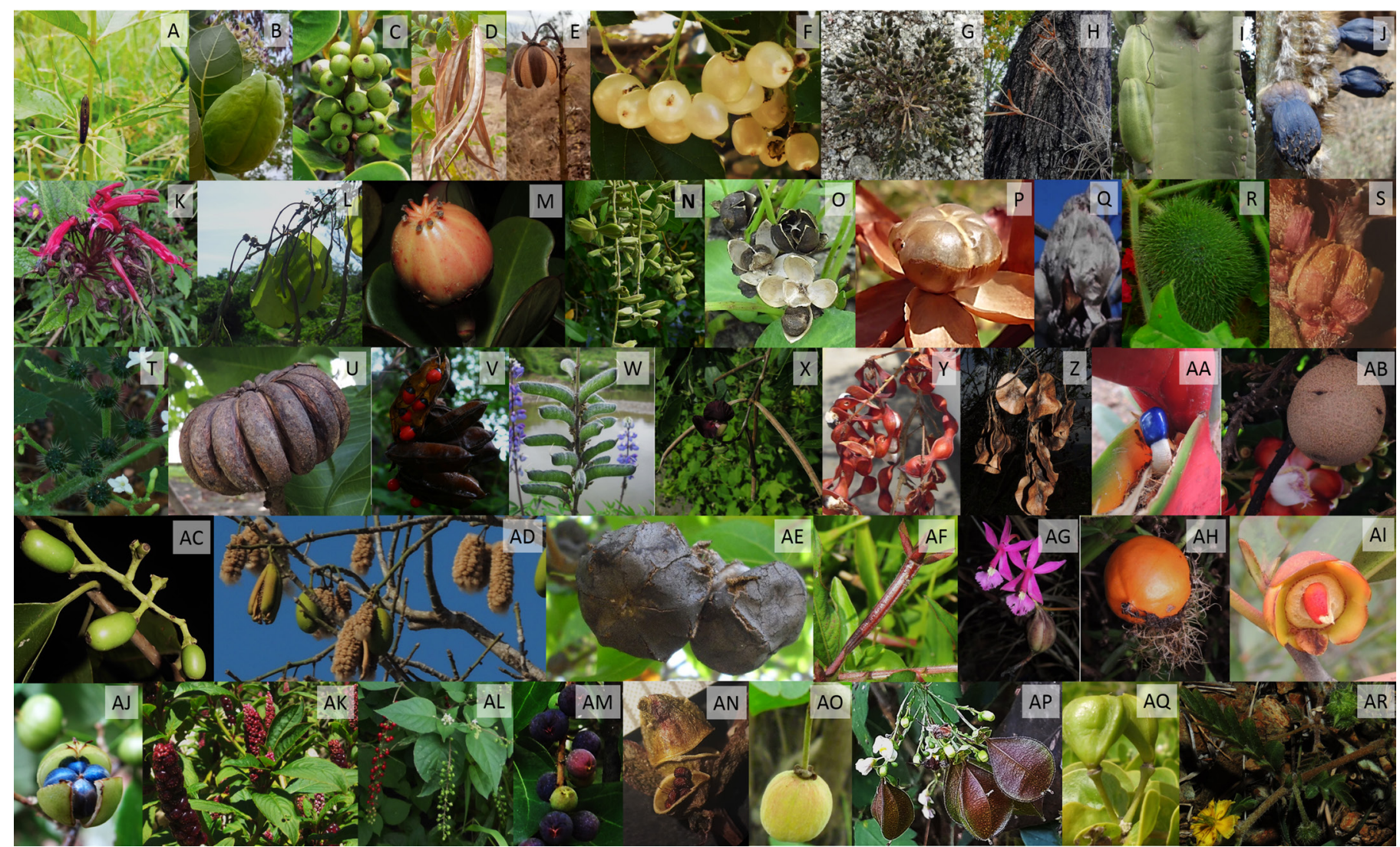

Figure 1. Fruits of some studied species ordered by family. Acanthaceae: (A) Ruellia tuberosa L. Apocynaceae: (B) Calotropis gigantea (L.) Dryand. in W.T. Aiton. Aquifoliaceae: (C) Ilex subrotundifolia Steyermark. Bignoniaceae: (D) Tecoma stans (L.) Juss. ex Kunth. Bixaceae: (E) Cochlospermum vitifolium (Willd.) Sprengel. Boraginaceae: (F) Cordia dentata Poir. Brassicaceae: (G) Draba chionophila S.F. Blake. Bromeliaceae: (H) Tillandsia recurvata (L.) L. Cactaceae: (I) Cereus hexagonus (L.) Mill.; (J) Pilosocereus lanuginosus (L.) Byles \& G.D. Rowley. Campanulaceae: (K) Siphocampylus reticulatus (Willd. ex Schult.) Klotzsch \& H. Karst. ex Vatke. Capparaceae: (L) Capparis hastata Jacq. Clusiaceae: (M) Clusia pusilla Steyerm. ssp. pusilla. Combretaceae: (N) Laguncularia racemosa (L.) C.F. Gaertn. Convolvulaceae: (O) Ipomoea pes-caprae (L.) R. Br.; (P) Operculina alata Urb. Crassulaceae: (Q) Kalanchoe pinnata (Lam.) Pers. Cucurbitaceae: (R) Cucumis dipsaceus Ehrenb. ex Spach. Euphorbiaceae: (S) Chamaesyce dioeca (Kunth) Millsp.; (T) Cnidoscolus urens (L.) Arthur; (U) Hura crepitans L. Fabaceae: (V) Abrus precatorius L.; (W) Lupinus meridanus Moritz ex C. P. Smith; (X) Macroptilium atropurpureum (Moc. \& Sessé ex DC.) Urb; (Y) Pithecellobium unguis-cati (L.) Benth.; (Z) Pterocarpus acapulcensis Rose. Heliconiaceae: (AA) Heliconia bihai (L.) L. Lecythidaceae: (AB) Couroupita guianensis Aubl. Loranthaceae: (AC) Phthirusa stelis (L.) Kuijt. Malvaceae: (AD) Ceiba pentandra (L.) Gaertn.; (AE) Thespesia populnea (L.) Sol. ex Corrêa. Onagraceae: (AF) Ludwigia octovalvis (Jacq.) Hara. Orquidaceae: (AG) Epidendrum secundum Jacq. Passifloraceae: (AH) Passiflora foetida var. hispida (DC. ex Triana \& Planch.) Killip. Pentaphylacaceae: (AI) Ternstroemia crassifolia Benth. Phyllanthaceae: (AJ) Margaritaria nobilis L. f. Phytolaccaceae: (AK) Phytolacca icosandra L.; (AL) Rivina humilis L. Polygonaceae: (AM) Coccoloba uvifera (L.) L. Portulacaceae: (AN) Portulaca oleracea L. Salicaceae: (AO) Hecatostemon completus (Jacq.) Sleumer. Sapindaceae: (AP) Urvillea ulmacea Kunth. Zygophillaceae: (AQ) Guaiacum officinale L.; (AR) Tribulus cistoides L. Photographers and photographies: J. Delgado (A, B, D, E, H), J. Grande (C, F, I, K, M, O, P, Q, U, W, X, Y, Z, AA, AB, AC, AD, AG, AH, AI, AL, AQ, AR), G. Colonnello (AJ), H. Briceño (G, AK), C. Aranguren (J), Y. Barrios (L, S, AE, AF, AM, AN, AO, AP), A. Villareal (N), K. Garcia (R) y B. Gil (T, V).

addition, beige seeds were most commonly found with black, brown, green, purple-black, red, white or yellow fruits (Appendix S2); black seeds were associated with brown or green fruits; and white seeds were most frequently found with black fruits. The fruit and seed color arrangements of some dehiscent fruits produced some bi-colored fruitseed structures, such that some fruits contained bright seeds and/or a bright internal surface. These types of combinations were mainly found in dry-dehiscent fruits (e.g. Abarema ferruginea) and fleshy-dehiscent fruits (e.g. Capparis flexuosa, Clusia pusilla).

The bipartite network analysis showed 71 different associations (links) between fruit and seed colors, representing 39\% of the total possible number of links (Table 3). The fruit color/seed color class ratio and the seed color/fruit color class ratio were both close to one. In contrast, the mean number of associations per fruit color and the mean number of associations per seed color were both slightly higher than 5.0.

\section{Morphological fruit types and fruit and seed colors}

\subsection{The texture and dehiscence of fruits vs. fruit and seed colors}

Fruit colors could be associated with structural fruit types such that most of the dry fruits were brown or black, whereas most of the fleshy fruits were purple-blacks, yellows or reds (Table 2). Comparisons between dry and fleshy fruits according to color categories showed that brown, black, and beige fruits were more often dry than fleshy. In contrast, the number of fleshy fruits that were purple-black, yellow, red, white, and blue was higher than the number of dry fruits with those colors. The most abundant fruit color was brown for both dehiscent and indehiscent fruits. Purple-black, black, yellow, and red were also common colors for indehiscent fruits. The statistical comparisons with 
Table 2. Relationship between structural fruit types and fruit and seed colors. Asterisk indicates the significant frequency $(\mathrm{P}<0.05)$ between dry and fleshy and between dehiscent and indehiscent fruits or seeds of the same color.

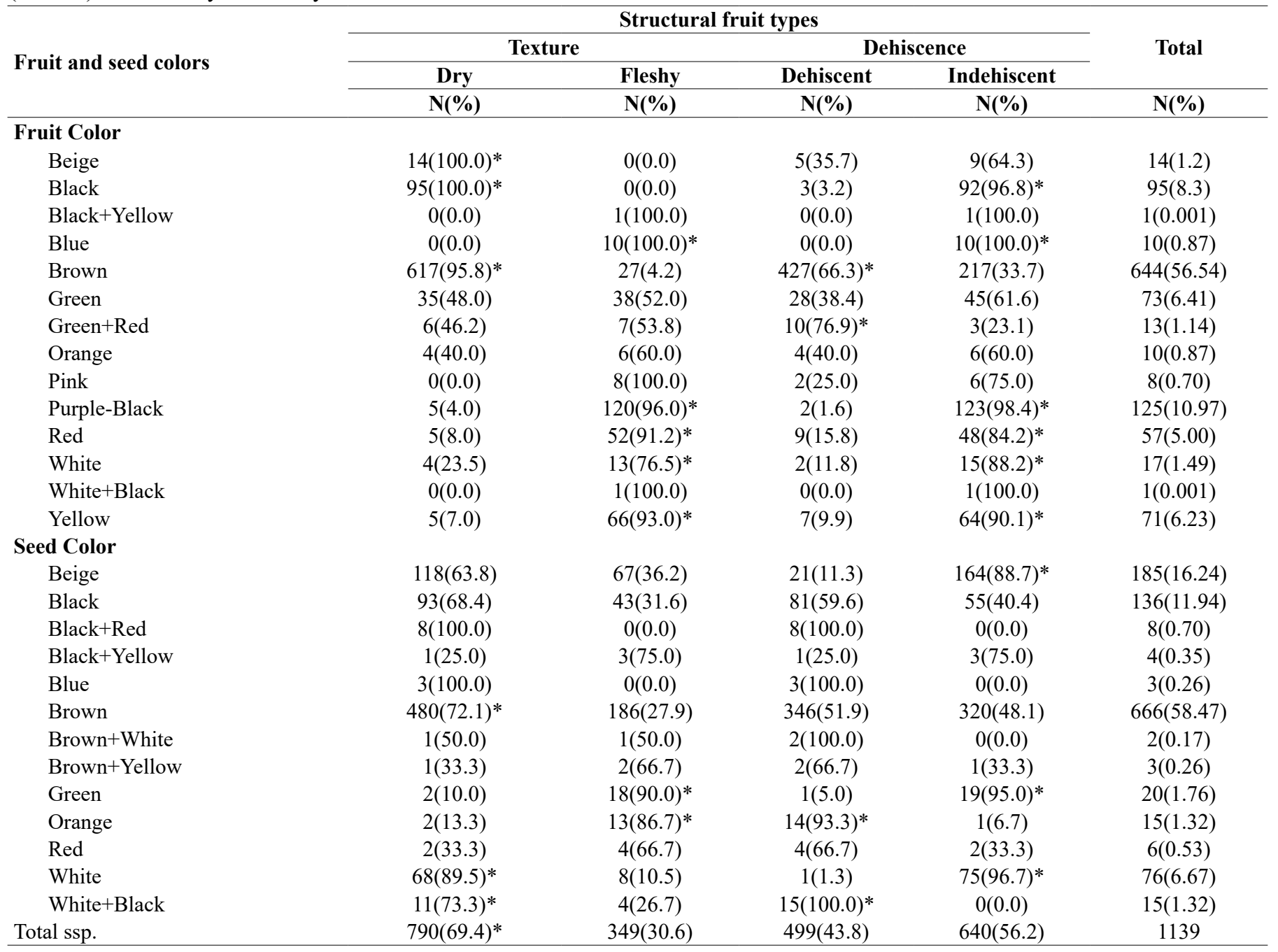

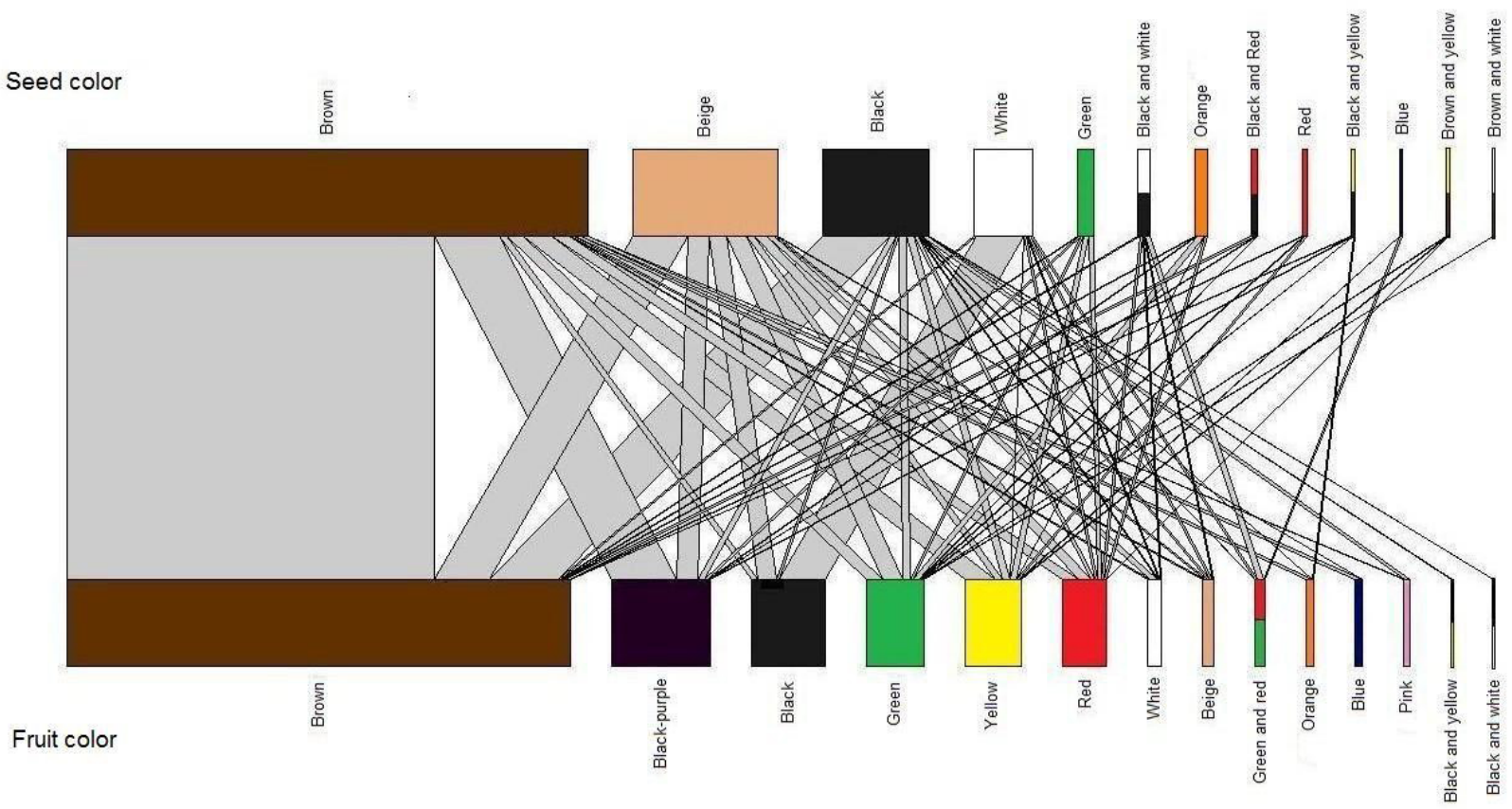

Figure 2. Bipartite graph showing the links between fruit and seed colors. 
Ramírez, N. et al.

Table 3. Morphological fruit types, fruit colors, and seed colors web parameters determined in the sample examined.

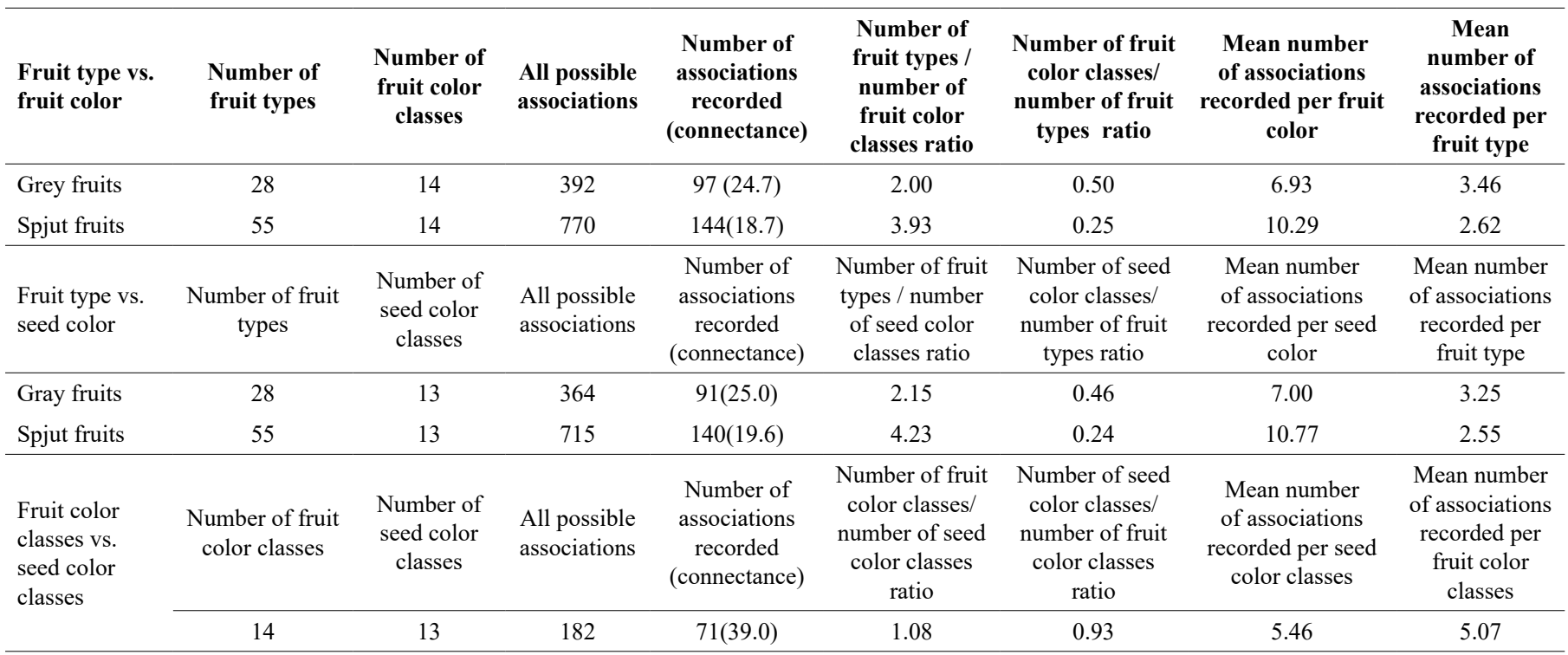

regard to the colors of dehiscent and indehiscent fruits showed that dehiscent fruits were most frequently brown and green+red, whereas indehiscent fruits were more likely to be purple-black, black, yellow, red, white, or blue (Table 2).

The most common seed colors were brown, beige, black, or white for dry fruits, and brown, beige, or black for fleshy fruits (Table 2). The statistical comparisons done between the seed colors of dry and fleshy fruits showed that a significantly higher proportion of dry fruits have brown, white or white+black seeds compared to fleshy fruits, and more fleshy fruits contain green or orange seeds than dry fruits. The analysis of the seed colors of dehiscent and indehiscent fruits revealed that dehiscent fruits were significantly more likely to contain orange or white+black seeds than indehiscent fruits, and indehiscent fruits were more likely to contain beige, white, or green seeds compared to dehiscent fruits.

\subsection{Gray and Spjut fruit types and fruit colors}

We found several major associations between morphological fruit types (I and II) and fruit colors (Appendix S1). The most common fruit color was brown for a large number of the morphological fruit types classified according to Gray's (1877) system (Figure 3). Fourteen of these morphological fruit types were represented by more than ten plant species (e.g. loculicidal capsule, followed by schizocarp, legume, and septicidal capsule) and some fruit types were exclusively brown (e.g. craspedium, loment, and samara). Achenes were well represented and predominantly black. As regards fleshy fruits, drupes and berries, more than twenty species of each of these fruit types were either purple-black, red or yellow. Brown was also the most common fruit color for morphological fruit types following Spjut (1994). Eleven brown colored fruit types were represented by more than ten plant species (e.g. loculicidal capsule, legume, and septicidal capsule, coccarium and ceratium) and some fruit types were exclusively brown (e.g. craspedium, loment, samara, and samarium). Cypselas were very abundant and predominantly black (Figure 4). As for the Gray (1877) classification system, fleshy fruits, drupes and baccas following Spjut (1994) were predominantly purple-black, red or yellow.

The bi-partite network analysis of the morphological fruit types according to Gray $v s$ fruit colors revealed 97 different links, representing
$24.7 \%$ of the total possible number (Table 3). The ratio between morphological fruit types and fruit color classes was four times higher than the ratio between fruit color classes and morphological type I fruits. The mean number of associations per fruit color was approximately twice the mean number of associations per morphological type I fruit. The relationship between the morphological fruit types according to Spjut and fruit colors showed comparable patterns (Table 3). However, there were 144 bi-partite network links between the Spjut morphological fruit types and fruit colors, representing $18.7 \%$ of the total possible number. The ratio between the morphological type II fruits and fruit color classes were much higher than the ratio between the fruit color classes and the morphological type II fruits. The mean number of associations per fruit color was approximately four times the mean number of associations per morphological fruit type.

The majority of fruit types (I and II) were associated with only one color (Figure 5). Nevertheless, a large proportion of the Spjut morphological fruit types were also associated with two fruit colors, and a few fruit types (both I and II) were associated with more than seven fruit colors (Figure 5).

The most common fruit types were associated with the same color categories, independent of the classification system used (I or II) (e.g. capsules and brown, schizocarps and brown, legumes and brown, and achenes and black). In other cases, asymmetrical associations as regards the level of specialization were recorded, whereby less common morphological fruit types (less than $1.0 \%$ of the total) tended to be associated with the most frequent fruit color classes. (See Figures 3 and 4). Asymmetry at the level of specialization was also observed between the least common fruit colors and the most common morphological fruit types (I and II). Thus, the lowest fruit color frequencies (white, beige, blue, orange, pink and bi-colored) were associated with the well-represented fruit types: capsule, berry and drupe (Figures 3 and 4).

\subsection{Gray and Spjut fruit types and seed colors}

According to Gray's classification system, twelve well-represented fruit types ( $\mathrm{N} \geq 10$; $\geq 10 \%$ ) had brown seeds (Appendix S3). Most plant species with brown seeds showed the following fruit types: berry, 


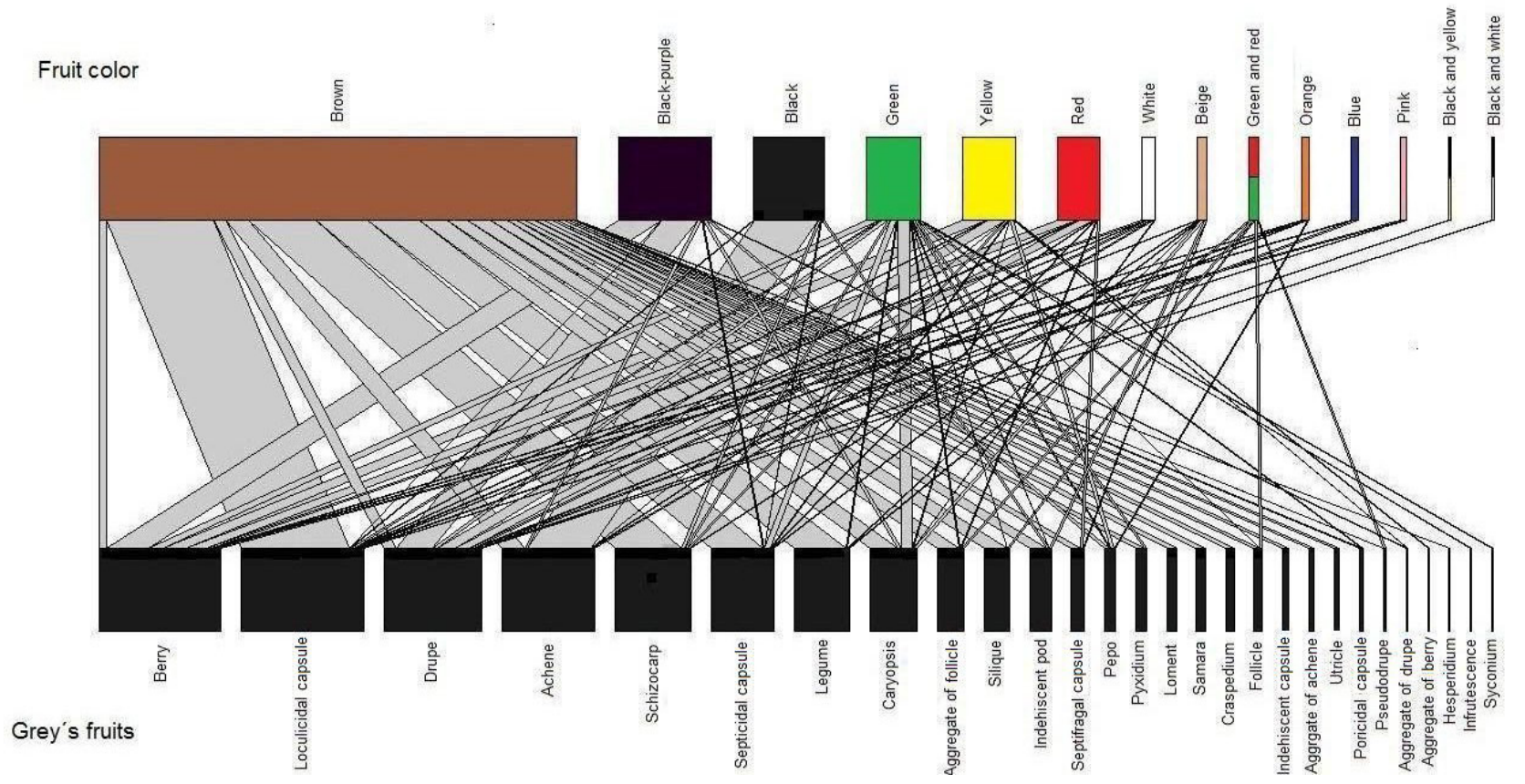

Figure 3. Bipartite graph showing the links between morphological fruit types according to Gray and fruit colors.

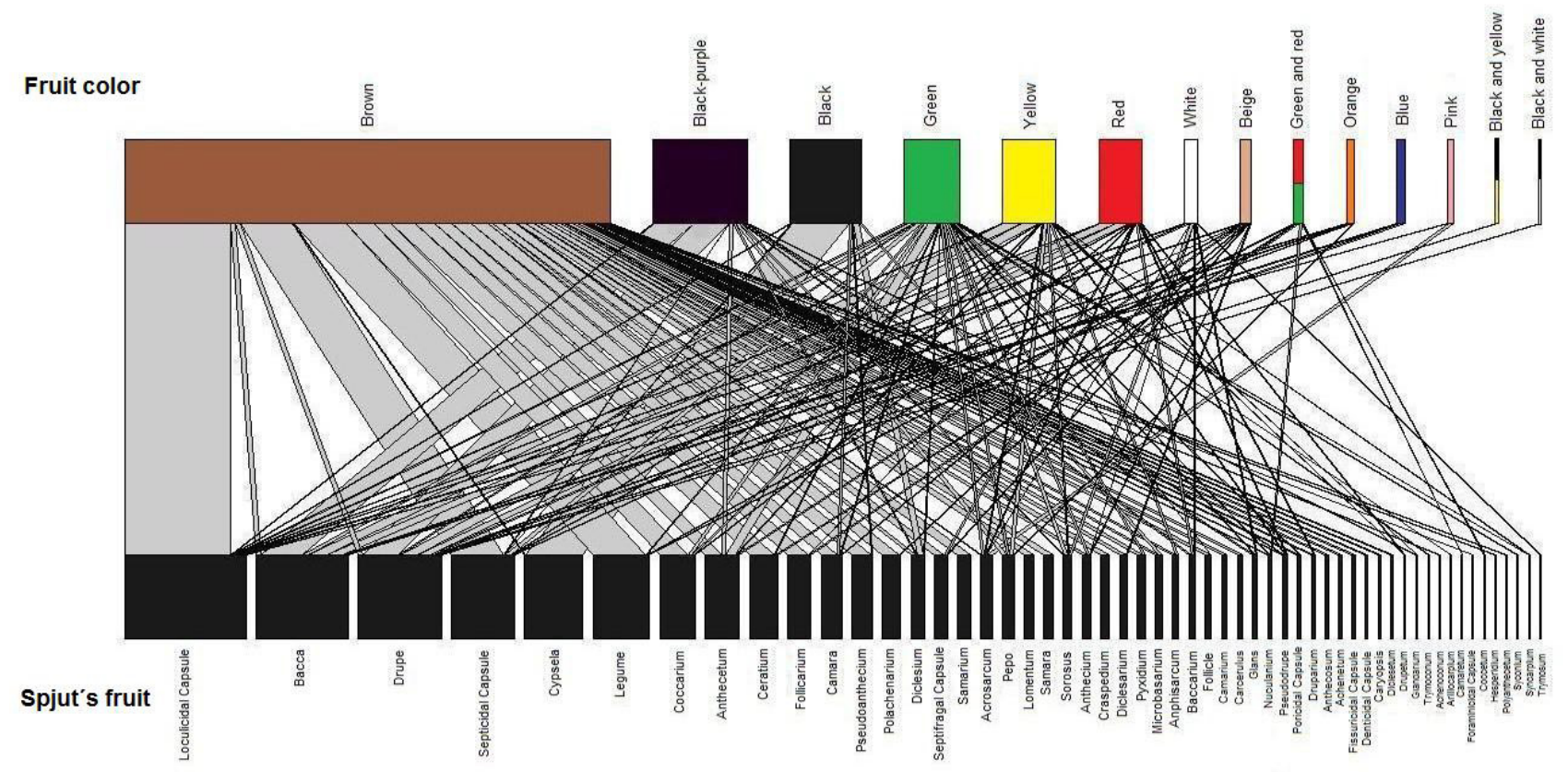

Figure 4. Bipartite graph showing the links between morphological fruit types according to Spjut and fruit colors.

schizocarp, loculicidal capsule, drupe, septicidal capsule and legume (Figure 6), and some fruit types always contained brown seeds (samara, craspedium and loment). A high number of plant species with caryopsis, drupe and berry morphological fruit types had beige seeds and a high number of achenes contained beige or white seeds. In contrast, a large number of loculicidal capsules and berries contained black seeds. The most frequent seed color associated with the morphological fruit types according to Spjut was brown followed by beige. Brown seeds were more numerous and frequent in loculicidal capsule, bacca, drupe, and legume, followed by coccarium and ceratium fruit types (Figure 7). Many plant species encompassing six morphological fruit types contained beige seeds; the highest numbers and percentages of these was found in anthecetum and pseudoanthecium fruit types, and some (samara, craspedium and loment) fruit types had exclusively brown seeds

The bi-partite network analysis used to determine the associations (or links) between morphological type I fruits (Gray's classification) and seed colors revealed 91 different links, representing $25.0 \%$ of the total possible number (Table 3). The ratio between the morphological fruit types and seed color classes was more than four times higher than the ratio between seed color classes and morphological type I fruits. The mean number of associations per seed color was more than twice the mean number of associations per morphological type I fruit. The same 

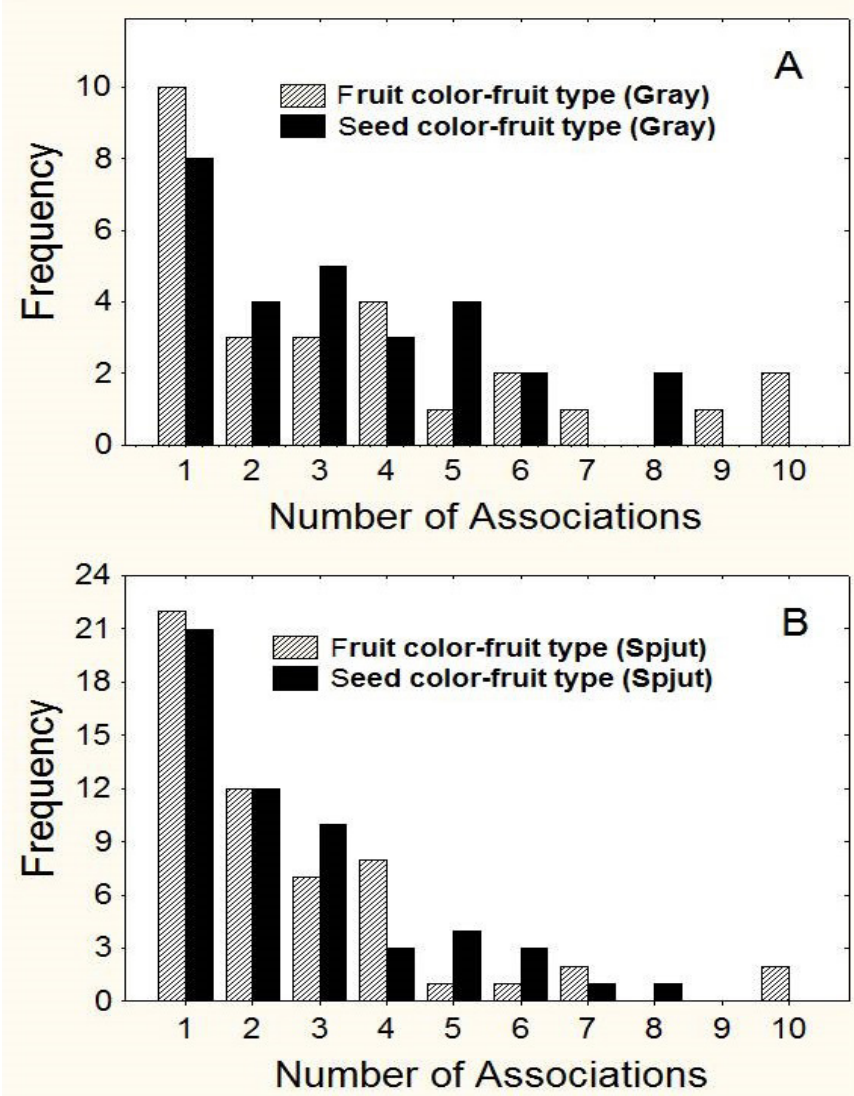

Figure 5. Frequency distributions of the number of associations of fruit types with fruit and seed colors for both Gray's (A) and Spjut's (B) classification systems.

analysis done for the morphological fruit types following Spjut and seed colors gave 140 different links, representing $19.6 \%$ of the total possible number. The ratio between morphological type II fruits and seed color classes was much higher than the ratio between seed color classes and morphological type II fruits. The mean number of associations per seed color class was more than four times the mean number of associations per morphological type II fruit.

Most fruit types (I and II) were associated with one seed color (Figure 5), however, twelve type II fruits were associated with two seed colors and a few fruit types (I and II) were associated with eight seed colors (Figure 5). Many links were also asymmetrical as regards the level of specialization, whereby the less common morphological type I and II fruits (less than 1.0\%) tended to be associated with the most common seed color classes (See Figures 6 and 7). Asymmetry at the level of specialization was also observed between the less common seed colors and the most common morphological fruit types (I and II) as follows: green, orange, red, blue and bi-colored seeds were associated with the best-represented fruit types (e.g. capsule, berry, drupe, and legume) (Figures 6 and 7).

\section{Morphological fruit types and functional groups}

\subsection{The texture and dehiscence of fruits and functional groups}

Fruit texture was significantly associated with life form, successional stage, nutritional relationship, carbon metabolism pathway, and fruit phenology (Table 4). Residual analyses indicated strong correlations between fleshy fruits and shrubs, and between dry fruits and annual herbs; and unusual occurrences between dry fruits and shrubs, and between fleshy fruits and herbaceous species. Similarly, fleshy fruits were strongly associated with late seral species, and there was an unusual occurrence between fleshy fruits and pioneer species. Fleshy fruits were also tightly linked to parasitic and hemiparasitic species; $\mathrm{C}_{4}$ species positively correlated with dry fruits and negatively with fleshy fruits; and fruit dehiscence was significantly associated with life form, nutritional relationship, carbon metabolism pathway, succulence, epiphytism and ripe fruit phenology (Table 4). Dehiscent and indehiscent fruits were similarly represented in herbaceous species, but indehiscent fruits were more common in trees, shrubs, and lianas. The fruits of parasitic and hemiparasitic species were also mostly indehiscent and matched the frequency of fleshy fruited species. All insectivorous species had dehiscent fruits which corresponded with dry-fruited species. Dehiscent fruits were more abundant than indehiscent fruits for $\mathrm{CAM}$ species. In contrast, $\mathrm{C}_{4}$ species had predominantly indehiscent fruits, and significantly unusual dehiscent fruits. Dehiscent fruits were found more often than indehiscent fruits in succulent species, and the opposite was true for non-succulents. Epiphytism was found to be independent of fruit texture, although epiphytes had predominantly dry fruits. Dehiscent fruits were found significantly more often than indehiscent fruits in epiphytic species, and indehiscent fruits were not generally associated with epiphytism. Both ripe and unripe fruit phenology was significantly associated with fruit texture, whereby fleshy-fruited species were positively associated with the rainy season and an uncommon occurrence of unripe and ripe fleshy-fruited species was observed during the dry season. Ripe and unripe fruit phenologies of dry-fruited species were positively associated with the dry season and unusual during the rainy season. Only ripe fruit phenology was significant for fruit dehiscence: plant species with indehiscent fruits tended to produce mature fruits during the rainy season (Table 4).

\subsection{Gray and Spjut fruit types and functional groups}

The frequency of fruit types (I and II) for each functional group can be seen in Appendix S4. The analysis of the relationships between morphological type I fruits and life forms showed that the most frequent fruit types in trees were berry, drupe, legume and indehiscent pod; for shrubs: berry and drupe; lianas: pepo; perennial herbs: achene, berry, loculicidal capsule, septicidal capsule, caryopsis, and schizocarp; and annual herbs: achene, loculicidal capsule, caryopsis, and schizocarp. Similarly, the analysis of the relationships between morphological type II fruits and life forms showed that the most frequent fruit types for trees were bacca, camara, and drupe; for shrubs: bacca and drupe; lianas: pepo, samarium and septifragal capsule; perennial herbs: anthecetum, cypsela, loculicidal capsule, pseudoanthecium, and septicidal capsule; and annual herbs: cypsela and loculicidal capsule (Appendix S4). The most frequent fruit types were berry, loculicidal capsule, septicidal capsule, and drupe in late seral species; and achene, caryopsis, schizocarp, and legume in pioneer species. The most numerous and frequent type II fruits were bacca, camara, ceratium, drupe, loculicidal capsule, and septicidal capsule for late seral species; and anthecetum, cypsela, legume, polachenarium, and septifragal capsule for pioneer species (Appendix S4). Both fruit types (I and II) were predominantly associated with autotrophic plants. $\mathrm{C}_{3}$ species were associated with almost all fruit types when type I fruits and carbon metabolism pathways 


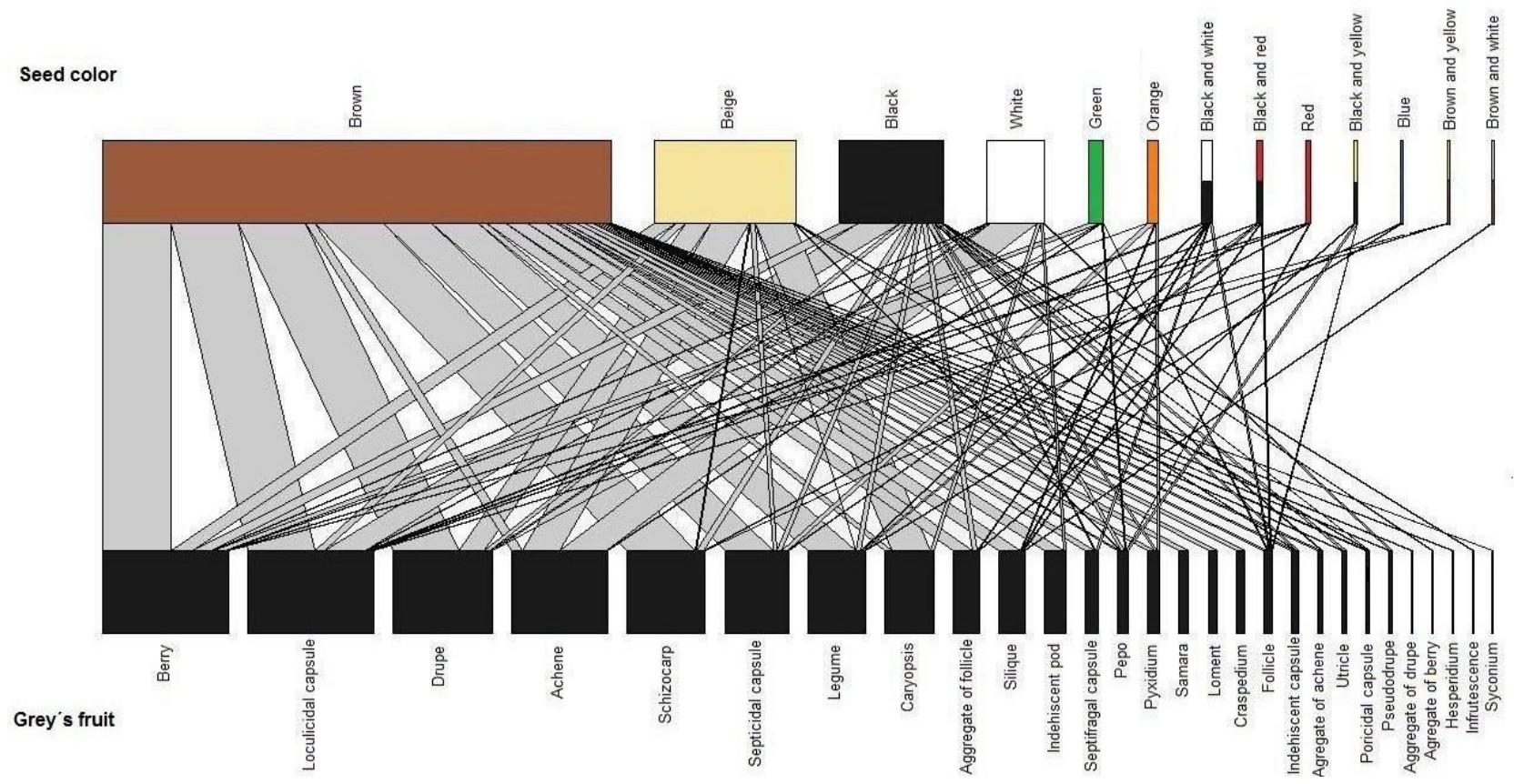

Figure 6. Bipartite graph showing the links between morphological fruit types according to Gray and seed colors.

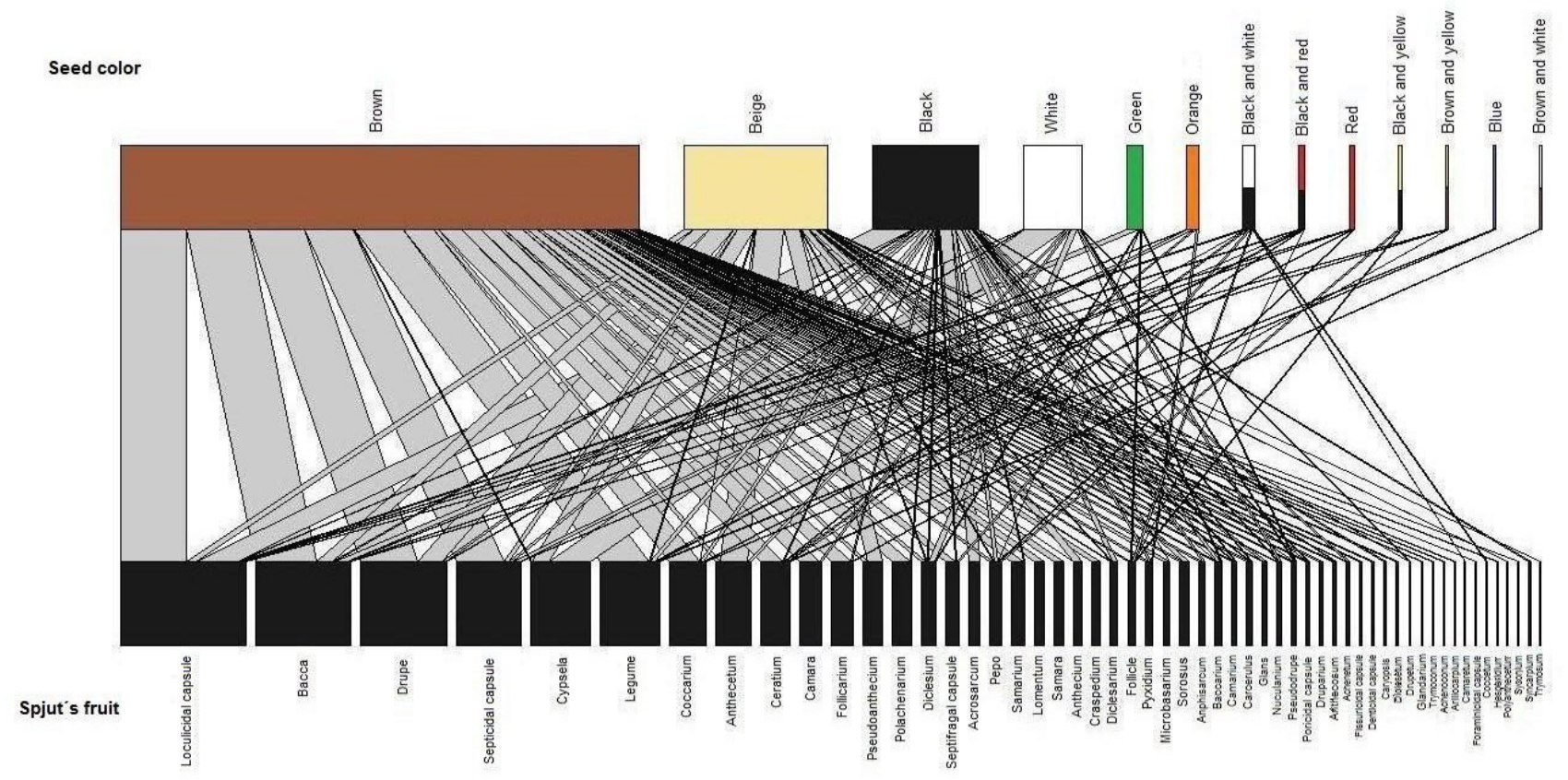

Figure 7. Bipartite graph showing the links between morphological fruit types according to Spjut and seed colors.

were compared. However, caryopsis and utricle fruit types from Gray's system, and anthecetum and pseudoanthecium fruit types from Spjut's system were mostly $\mathrm{C}_{4}$ species. In addition, many succulents and CAM species produced acrosarcum fruit types. Nonetheless, in general, the most abundant and frequent fruit types I and II were associated with non-succulent species. Septicidal capsule was the main morphological fruit type found in epiphytes (Appendix S4).

Seasonality in unripe and ripe fruit phenology during the transition period between the rainy and dry seasons was recorded for the most abundant morphological type I (e.g. achene, berry, drupe, loculicidal capsule, and schizocarp) and type II (e.g. bacca, drupe, loculicidal capsule, and septicidal capsule) fruits. A few plant species tended to produce more unripe fruits during the rainy season: caryopsis and silique following Gray's classification and anthecetum, ceratium and coccarium, according to Spjut's classification (Appendix S4). Other species tended to produce ripe fruits during the rainy season: drupes and siliques (Gray's classification), and drupes (Spjut's classification). In contrast, samara and samarium fruit types mainly ripened during the dry season.

\section{Fruit and seed colors and functional groups}

The number and percentage of the fruit and seed colors studied, and their frequencies according to the functional groups identified are shown 
Ramírez, N. et al.

Table 4. Relationship between structural fruit types and functional groups

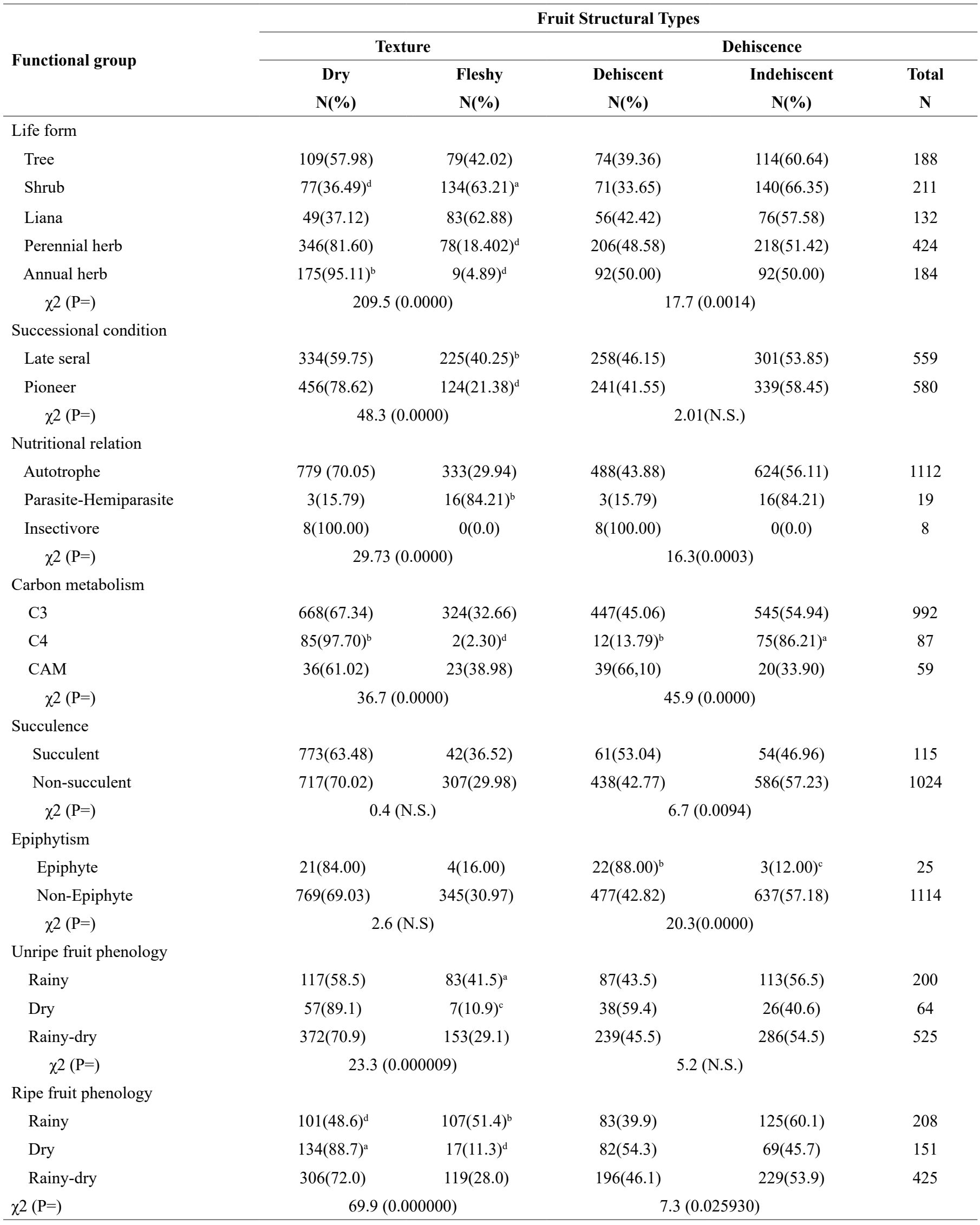

Superscript indicates significance residual analysis: $\mathrm{a}=$ positive residual at $\mathrm{P}<0.05 \quad \mathrm{~b}=$ Positive residual at $\mathrm{P}<0.01 ; \mathrm{c}=$ negative residual at $\mathrm{P}<0.05 ; \mathrm{d}=$ Negative residual at $\mathrm{P}<0.01$ 
in Appendix S4. The most common colors $(\mathrm{N}>10 ; \geq 10 \%)$ were brown and purple-black for fruits, and brown, beige, and black for seeds. The relationships between fruit colors and life forms showed that the most frequent colors were brown, green or yellow for trees; purple-black or red for shrubs; and black or brown for perennial and annual herbs. The main fruit colors that could be associated with the successional stage were brown or purple-black for both pioneer and late seral stage species. In addition, black fruits were significantly correlated with pioneer species, and green or yellow fruits with late seral species. Most autotrophs, $\mathrm{C}_{3}$ and non-succulent species had single-colored fruits; pink fruits were common for CAM and succulent species; and brown was the most frequent color for the fruits and seeds of epiphytes.

Brown was the most common seed color for species in all the life forms studied. Nevertheless, the most frequent seed colors were orange and white+black for trees; orange and beige for shrubs; beige, black, green, and white for perennial herbs; and white for annual herbs. Brown, beige and black were the most abundant and frequent seed colors for both pioneer and late seral species. However, white seeds were also significantly associated with pioneer species, and green and orange seeds with late seral species. Autotrophs, $\mathrm{C}_{3}$ and non-succulent species generally had single-colored seeds, and green seeds were common in parasitic and hemiparasitic (mistletoe) species (Appendix S4). Fruit and seed colors exhibited some trends according to fruit phenology (Appendix S4). Unripe and ripe fruits produced during the rainy-dry transition period were often black, brown, green, or purple-black. Unripe red or yellow fruits were also produced during this period. However, ripe red or yellow fruits were most common during the rainy season. Beige, black, brown, green, orange, and white were the most abundant seed colors during the rainy-dry transition period.

\section{Discussion}

\section{Morphological fruit types}

A first analysis of fruit structures indicates that texture and dehiscence are closely related. Dehiscence is an attribute largely associated with dry tissues adapted to fruit opening by the desiccation of the fibers. Nonetheless, dehiscence was also found in a few fleshy fruits (e.g. Clusia spp.). The pericarp of dehiscent fruits protects seeds until dehiscence and may also be involved in dispersion during fruit opening, after which seed protection and dispersal is determined exclusively by seed attributes. In contrast, indehiscence is an attribute associated with both dry and fleshy fruits, and principally involves fruit adaptations related to enclosure of the seeds, although it is also associated with a variety of reproductive and ecological functions (Cippollini \& Stiles 1992, Mack 2000). Dry-indehiscent fruits may be primarily adapted for seed defense from animals and parasites by means of the hard fibrous cover which acts as a shield (Bodmer 1991, Doster \& Michailides 1999). Nevertheless, the high diversity of modifications of the pericarp and anthocarp in indehiscent fruits also reflects adaptations to seed dispersal (e.g. Mamut et al. 2014). The ratio of species with dry fruits to those with fleshy fruits has been found to be similar in tree species from Southern Africa (Knight \& Siegfried 1983). Many other studies, however, have shown that species with dry fruits outnumber those with fleshy fruits in varying proportions (Gordon 1998, Silva \& Rodal 2009, Silva et al. 2013, Possete et al. 2015) including in our survey where the number of species with dry fruits was more than twice the number with fleshy fruits. A phylogenetic study revealed that the majority of plant families produce dry fruits (Fleming 1991). Thus, the high frequency of species with dry fruits observed seems to agree with expected ratio for fruit texture types.

The most abundant fruit types found in the samples studied were loculicidal capsules, berries (baccas), drupes and achenes. This agrees with previous studies which also note that capsules tend to be the main fruit type in the forest-shrub ecosystem (Arbeláez \& Parrado-Rosselli 2005), although berries and drupes may be dominant in some rain forests (Carpenter et al. 2003, Chen et al. 2004, Ibarra-Manríquez \& Cornejo-Tenorio 2010, Buitrón-Jurado \& Ramírez 2014). Thus, the relative frequencies of morphological fruit types seem to vary according to ecological attributes. Nevertheless, the influence of the phylogenetic component is also significant as the majority of plant families produce dry fruits (Fleming 1991, Heywood et al. 2007, Fleming and Kress 2011), and in some cases the relationships between fruit types, seed dispersal strategies and vegetation life forms have been best explained by angiosperm phylogeny (Kuhlmann \& Ribeiro 2016). The frequencies of fruit type we observed could thus also be influenced by the taxonomic composition of the samples, in which species from the Fabales, Malphigiales and Poales orders, and the Fabaceae family were overrepresented (N. Ramírez \& H. Briceño, in preparation), and contributed significantly to the abundance of dry-dehiscent and dryindehiscent fruits. Nonetheless, the most dominant orders and families in the sample we examined formed a different group to that of "most frequent fruit types". Hence we did not consider the phylogeny of the plant species as a major factor in our analysis.

The classification systems of Gray (1877) and Spjut (1994) coincided in many areas as regards nomenclature and the general morphology of the fruit types studied (i.e. berries, loculicidal capsules, drupes, septicidal capsules, legumes, and siliques). Most of the similarities between the two systems are for simple fruits (fruit not dispersed from the pericarpium; developing from one flower) and rhexocarpic fruits (fruit dispersed by the opening of the pericarp). This is because the differences in the fruit types according to each system mostly refer to anthocarp structure (see Spjut 1994), which may thus be considered as the main source of adaptations related to functional groups.

\section{Fruit and seed colors}

Eleven single-colored and seven bi-colored categories were found in the samples studied; fruits were predominantly dark in color (brown, purple-black or black) whereas seeds could be either dark or light (brown, beige, black or white). The similarity in both the number and classes of fruit and seed colors may reflect well-adjusted color arrangements between fruits and seeds. Fruit/seed color and seed/ fruit color ratios were both close to one, suggesting that the relative frequencies of fruit and seed colors are finely balanced. Likewise, the high diversity of links between fruit and seed colors, and between seed and fruit colors showed many similarities and multiple combinations. Fruit and seed color associations revealed a large proportion of linkages (39\%), whereby the most common colors were preferentially associated with each other, and the less frequent colors were usually associated with those that were well represented. Specifically, the four seed color categories with the highest frequencies (brown, beige, black, and white) were generally associated with the most common fruit colors (brown, 
purple-black, and black). Preliminary findings from the complex networks analysis suggest that the associations between fruit and seed colors form three modules: 1- black fruits and white seeds; 2- brown fruits, and brown or black seeds; and 3-purple-black fruits and beige seeds (Y. Barrios unpubl. results). However, brown fruits with brown seeds were the only really significant combination $(72.9 \%)$, and were mainly associated with dry-dehiscent fruits. In addition, brown fruits and beige seeds stood out as module hubs within the network (Y. Barrios unpubl. results), and thus represent highly connected nodes linked to many other nodes within their own module (Olesen et al. 2007). Additional analyses showed that this network was symmetrical according to the levels of specialization of the fruit and seed color categories, and was characterized by specificity indexes with low averages for both fruit and seed colors (Y. Barrios unpubl. results).

The least common color categories for single-colored fruits were white, beige, blue, orange, and pink, and for single-colored seeds, green, orange, red and blue. Thus, blue and orange coincided in that they showed some of the lowest frequencies for both fruits and seeds. Further relationships recorded between the relative frequencies of fruit and seed colors were: 1 - white and beige colors were comparatively more common in seeds than in fruits, 2- green and red colors occurred at lower frequencies in seeds compared to fruits, and 3- pink was only found in fruits. In spite of this, orange fruits appear as the main fruit color for animal dispersed seeds (Willson \& Thompson 1982, Wheelwright \& Janson 1985, Mikich \& Silva 2001, Selwyn \& Parthasarathy 2006) but are infrequent for plants with other dispersal strategies (Liu et al. 2014). White fruits occur at low frequencies in several different plant communities (Willson \& Thompson 1982), and could represent specific associations between fruit color and particular seed disperser species (Guaraldo et al. 2013), or may be unapparent to many undesirable frugivorous animals. Likewise, less common colors such as blue, orange and pink in fruits and seeds might also represent specific color-based adaptations for attracting a particular seed disperser. For example, lizards are an unusual seed disperser, and have been found to prefer white-blue fruits from open habitats (Wotton et al. 2016). Some fruit and seed colors occurring at low frequencies may be associated with certain types of plant communities and habitats. For instance, most of the bright-blue fruits and seeds were from cloudy-rainy plant communities. Green seeds were uncommon and mostly associated with photosynthesis in mangroves and mistletoes, and red seeds were mainly arillated seeds dispersed by birds. All categories of bi-colored fruits and seeds were also found at low frequencies, which contrast with previously recorded results: two- and three-color combinations have been found to be quite common in fruit dispersed by vertebrates (Wheelwright \& Janson 1985, Willson et al. 1989, Mikich \& Silva 2001, Galetti et al. 2011). Thus, a high frequency of bi-colored fruits can be related to frugivorous animaldriven dispersal, and a low frequency of bi-colored fruits is expected for surveys of overall fruit color categories. However, multicolor fruit-seed structures, resulting from the combination of fruit and seed colors, may increase the frequency of multicolor attractive units.

Fruit and seed colors also differed as regards the number of bicolored categories. More color combinations for seeds compared to fruits can be primarily associated with contrasting color combinations between the seed coat and accessory structures such as arils. Bi-colored seed combinations may be also related to the large number of plant species with bird-dispersed seeds (Galetti et al. 2011). Bi-colored seeds are, in some cases, also associated with cryptic seeds providing no nutritious pulp (Ridley 1930, van der Pij1 1972). The high number of bi-colored seed combinations found in our study can thus be correlated with different functions and alternative dispersal mechanisms. The most common colors of bi-colored fruits and seeds included black combined with one of three other colors, and combinations of brown, white, yellow, and red. Accordingly, the presence of the color black in bi-colored fruits and seeds seems to have the function of providing a sharp contrast to a bright color. Two- and three-color combinations usually involve black with other colors, usually red and/or yellow (Willson \& Melampy 1983, Wheelwright \& Janson 1985, Willson et al. 1989). Our results suggest that the black+red seed combination is common in tropical zones. Other combinations of colors and patterns may, however, be found depending on the plant species examined.

Fruits may be bi-colored due to the combination of fruit and seed colors, and this may also result in fruits with more than two colors. The exocarp or aril is usually the colorful structure, although other fruit parts including elaisomes and fruit/seed contrasts may also act as visual attractants (van der Pijl 1982). Thus, the combinations of fruit and seed colors may represent significant adaptations enabling bi-colored fruitseed structures to have different functions, where texture and dehiscence may also be involved. Most of these multicolored structures are found in dehiscent bi-colored fruits where attractiveness may increase if a brightly colored seed is visible as part of the fruit-seed structure. Seed attraction may also be enhanced when fruit color contrasts with seed color, or when seed coat and aril colors differ. Asymmetries in the level of specialization between the fruit or seed colors with the lowest frequencies and the well-represented morphological fruit types suggest that uncommon colors could represent a specialized trait for animal dispersal, or as protection via crypsis against herbivory (Cazetta et al. 2009). Asymmetrical associations between the least common morphological fruit types and the most common fruit or seed color classes were found for many rare fruit types which had fruits or seeds with a variety of functions.

\section{Fruit types and fruit and seed colors}

Morphological fruit types according to Gray showed association values (connectance) of close to $24 \%$ for the fruits and seeds studied, and were higher than the values calculated using Spjut's classification. These differences can be mainly explained by the higher number of fruit categories in Spjut's vs. Gray's classification. The lower connectance between fruit and seed colors following Spjut's classification indicates that the associations were relatively specific, i.e. each fruit type was linked to a comparatively low number of seed or fruit colors, respectively. Accordingly, the ratios between the number of fruit types and the number of fruit color classes, and between the number of fruit types and the number of seed color classes were higher for Spjut's than for Gray's classification. The mean number of links recorded per fruit color was close to the mean number of links recorded per seed color for both fruit types (I and II). However, the values for type II fruits were higher than those for type I fruits, which again can be related to the higher number of fruit categories considered by Spjut (including modifications of the anthocarp) which results in a greater diversity of associations, leading to multiple combinations. The mean number of links per fruit type (I and II) was lower than the mean number of links per fruit and seed color: more than twice as low for type I fruits, and 
more than four times as low for type II fruits. Such trends indicate that the mean number of associations for each fruit and seed color increases with an increase in the number of fruit types, and that the mean number of associations for each fruit type slightly decreases with an increase in the number of fruit types.

Adaptations to a specific set of mutualists may occur more frequently than currently acknowledged in color signaling, even in megadiversified networks of mutualistic interactions (Renoult et al. 2014). The frequency distribution of the number of color-based interactions per fruit type indicates that despite the large number of associations, the majority of fruit types (I and II) were single-colored, although bi-colored fruits and seeds were also common for type II fruits. On the other hand, only a few fruit types were associated with more than eight fruit and seed colors, and therefore with a well-defined (leptokurtic) connectivity distribution (Jordano et al. 2003). In this context, the distribution of the associations between these attributes agrees with complex networks theory: large numbers of nodes have only one or two links, and only a few nodes have a large number of links. These frequency distributions of the number of color-based interactions among fruit types also suggests that there are asymmetries in the level of specialization (Bascompte \& Jordano 2007), whereby less common fruit and seed colors tend to be associated with the most common fruit types (both I and II).

The most significant associations were mainly found in dry fruits with the most common being brown with loculicidal capsules, and black with achenes. Septicidal capsules, legumes, and schizocarps also tended to be brown. In fact, several studies have shown that most dry fruits are brown (López \& Ramírez 1989, Knight and Siegfried 1983, Parisca \& Ramírez 1989, Carpenter et al. 2003, Ibarra-Manríquez \& Cornejo-Tenorio 2010, Possete et al. 2015). The pods and capsules surveyed in different tropical forests were also mostly brown (Selwyn \& Parthasarathy 2006, Ibarra-Manríquez \& Cornejo-Tenorio 2010). The predominance of dark fruits can be related to their higher capacity to absorb solar radiation which might accelerate metabolism and ripening times (Janzen 1983, Wheelwright \& Janson 1985), and could also provide a protective function due to the high concentrations of anthocyanins (Schaefer 2011) and tannins. In addition, the color black may act as a protective barrier against insolation for seeds in dry-indehiscent fruits. Dark colors absorb more radiation in the visible spectrum than pale colors (Wheelwright \& Janson 1985) thus shielding seeds from it. Brown is the main plant tissue color at the end of the developmental processes of any plant organ, as well as the color of dry tissues; fibrous plant tissues are also often brown (Esau 1953). The brown fruits and seeds of species with dehiscent fruits may constitute a protective trait in several ways: the aposematic coloration of brown fruits may advertise the unattractiveness of the fruit to animal predators (Knight \& Siegfried 1983). Brown indehiscent fruits, and brown seeds from dehiscent fruits could also avoid predation through crypsis (matching soil color) as proposed by Liu et al. (2014). The fibrous nature of mostly dry-brown fruits and seeds from dehiscent fruits is a characteristic significantly related to fruit protection, and is favored under strong selection pressure from herbivores (Bodmer 1989, 1991). In fact, dehiscence in fruits has been associated with both fiber content and seed protection (Gautier-Hion et al. 1985). To summarize, the brown coloration of dry fruits at maturity could be associated with several adaptive functions: 1- brown could be considered as the least expensive color (compared to bright colors); 2- brown fruits may be cryptic, thus making them unapparent to herbivores; 3 - abiotic dispersal is independent of any specific color, such as that employed by indehiscent-brown fruits; 4- explosive dehiscent fruits require a fibrous fruit-wall for dispersal; 5- dehiscence and brown fruits may also converge in cases where seeds may act as both dispersal unit and self-protective structure.

Bright fruits, together with purple-black (dark) fruits are more likely to interact with the environment than seeds (which are frequently enclosed in indehiscent fruits, or dark seeds are produced by dark fruits), which could explain the greater diversity in the coloration of the former. Most fleshy-fruited species are conspicuously displayed by having fruits that are brightly colored when ripe (French 1991). Fleshy fruits were somewhat less specific as regards their color, and only drupes and berries (baccas) tended to be a particular color, purple-black, which agrees with the commonly found association between these types of fruit and the dispersal of seeds by animals at the community level (Willson \& Thompson 1982, Knight \& Siegfried 1983, Wheelwright \& Janson 1985, López \& Ramírez 1989, Willson et al. 1989, Bosque et al. 1995, Selwyn \& Parthasarathy 2006, Ibarra-Manríquez \& CornejoTenorio 2010, Buitrón-Jurado \& Ramírez 2014). The dominance of purple-black drupes and berries may also be related to the number of species belonging to the following plant families: Melastomataceae, Lauraceae, Rubiaceae, Aquifoliaceae, and Symplocaceae (Wheelwright \& Janson 1985, Buitrón-Jurado \& Ramírez 2014). However, no effects of phylogenetic constraints, either at the family or the genus level, have been found when explaining community-wide variations and patterns in fruit color (Janson 1983, Willson et al. 1989). Purple-black fruits have been associated with the visual perception of birds, which are considered the main seed dispersers in both temperate and tropical sites (Willson et al. 1989). Moreover, purple-black fleshy fruits may absorb more radiation in the visible spectrum (Wheelwright \& Janson 1985 ) thereby raising fruit temperatures and leading to an increase in metabolic and developmental rates (Janzen 1983). The predominance of purple-black over red in fleshy fruits relying on bird seed dispersal seems to be a characteristic feature of most plant communities (Knight \& Siegfried 1983, Wheelwright \& Janson 1985, Nakanishi 1996, Galetti et al. 2011) except savannas (Donatti et al. 2007). Bright (red and yellow) colors show lower specificity according to fruit types, although fleshy fruits, drupes and berries are often these colors. Bright colors are a key characteristic of fruits because they raise the probability that the fruits will be noticed or selected, and consequently that their seeds will be dispersed (Wheelwright \& Janson 1985). In addition to signaling location, fleshy fruit colors may convey information about fruit quality that would influence a bird's choice of meal (Wheelwright \& Janson 1985). Different colored fruits seem to be dispersed by different dispersal agents, although this is a tendency rather than a rule. In fact, plant-seed dispersal networks show low levels of specificity (Blüthgen et al. 2007), although drupes and berries favored by birds for seed dispersal are more likely to be brightly colored, whereas those eaten principally by mammals tend to be yellow or green (Knight \& Siegfried 1983, Willson et al. 1989, Voigt et al. 2004, Galetti et al 2011). Yellow- fleshy fruits are generally found in relatively low frequencies at the community level (Willson \& Thompson 1982, Chen et al. 2004, Possete et al. 2015). In this study we recorded comparatively low numbers of yellow-fruited species, despite the inclusion of a few yellow-dry fruits in the plant species examined. 
Morphological fruit types and seed colors exhibited similar associations as compared to fruit type and color. The seeds of fleshy and dry fruits may form clusters around the same color. For example, brown seeds are associated with berries, schizocarps, loculicidal capsules, drupes, septicidal capsules and legumes; indicating that brown is the most common seed color irrespective of fruit texture and dehiscence. In fact, the seed coat is brown in diverse fruit types (Parisca \& Ramírez 1989, López \& Ramírez 1989, Gordon 1998). The frequency distributions of the number of seed color links per fruit type also suggests the existence of very cohesive associations, with clusters of the most common fruit types and color categories converging among themselves. Specifically, a high number of dry-indehiscent and fleshy-indehiscent fruits had beige seeds (achene, caryopsis, drupes and berries), and beige, white, and green seeds were more abundant in indehiscent than dehiscent fruits. The predominance of light-colored seeds in indehiscent fruits is probably related to a thin seed coat, low fiber content, and no protective function given by the fruit. Beige seeds were the second most common seed color and form several clusters with achene and caryopsis (anthecetum and pseudoanthecium) fruit types; and white seeds form a large cluster with achenes. The high frequencies of beige and white seeds in the sample examined agrees with previous studies of diverse fruit types (López \& Ramírez 1989, Gordon 1998) and seems to be related to the high proportion of these seeds in dry-indehiscent fruits. These trends show that light colored seeds are associated with dark indehiscent fruits, and that black seeds may occur in both dehiscent and indehiscent fleshy fruits. For example, achenes (cypselas) were predominantly black with a high number of species with white or beige seeds. Light-colored seed coats seem not to interact directly with either biotic or abiotic factors, and thus in species with these seed colors, fruit color could be more important. Dark fruit colors, for example, could protect the seeds from biotic and abiotic factors and could thus be associated with a great variety of functions (Cazetta et al. 2009). In some cases, however, light-colored seeds are significantly associated with rapid germination (Thompson 1993, Gordon 1998, Debeaujon et al. 2000). Hence, light colors in seeds could be linked to basic processes to do with the establishment and development of seedlings (Debeaujon et al. 2000), and in some cases with abiotic seed dispersal.

Brown seeds seem to be mainly associated with dehiscent fruits which are mostly brown and sometimes black, and are the most common colors found in plant species. Dark colors (black and brown) may give protection against physical factors as they absorb more radiation in the visible spectrum than pale colors (Wheelwright \& Janson 1985). This also raises fruit temperature, thus increasing metabolic rate and speeding up the ripening process (Janzen 1983). Hence, dark colors could contribute to providing energy for germination and may also protect embryos from radiation. In addition, brown and black seeds are related to high fiber tissues (Stringam et al. 1974, Daun \& DeClercq 1988 ) and may provide protection against post-dispersal seed predation (Bodmer 1989, 1991). Moreover, brown and black colors may enable seeds to avoid advertising their presence to post-dispersal seed predators through crypsis with the soil, and might also serve as protective mimetic colors in species that employ abiotic seed dispersal mechanisms (Nystrand \& Granström 1997). Brown and black seeds, in combination with their structure, are also associated with plant species dispersed by granivorous animals (e.g. Pirk \& Casenave 2006). In some animal dispersed species, black seeds may be combined with a contrasting color of one or more parts of a fruit, such as the pulp of some fleshy fruits (e.g. some Cactaceae). Two-color combinations of seeds are usually black plus another color, and are found in some animal dispersed fruits (Willson et al. 1989, Wheelwright \& Janson 1985). A higher proportion of brown, white or bi-colored (black+white) seeds were found in dry fruits compared to fleshy fruits, and green or orange seeds were more likely to be found in fleshy fruits than dry fruits. The most common color found in both fruits and seeds, however, was brown. Brown fruits coincided with brown seeds in numerous fruit types: loculicidal capsule, schizocarp, legume, and septicidal capsule, and included fruit types and seeds that were exclusively brown (samara, craspedium and loment). Brown seeds were also found in the most abundant fleshy indehiscent fruits: purple-black, red or yellow berries and drupes, and can be related to seed protection. For example, berries are ingested by animals and the seeds need some protection for their survival which might be given by a fibrous-brown seed-coat (Bodmer 1989, 1991, Parisca \& Ramírez 1989).

\section{Fruit types, fruit and seed colors, and functional groups}

Morphological fruit types show attributes that are closely related to their different colors and diverse functional traits. Hence, color, dehiscence, texture and their corresponding morphological fruit types following either Gray (1877) or Spjut (1994) were predominantly associated with plant life form, epiphytism, physiology, nutritional relationships, fruit phenology, and the successional stage they inhabit

Fruit texture and dehiscence were associated with particular life forms: fleshy and dry fruits with trees, fleshy fruits with shrubs, and dry-dehiscent and dry-indehiscent fruits with herbs. This agrees with Fleming (1991) who found that dry fruits were dominant in herbaceous plant families whilst woody families had a more even mix of fruit types with fleshy fruits predominating. Other studies indicate that fleshy fruits are strongly linked to shrubs whilst dry fruits are associated with annual herbs, suggesting that fruit texture may be influenced by plant size, woodiness, and life span (Burrows 1994, Herrera 2002a, b, Patterson \& Givnish 2002, Bolmgren \& Eriksson 2005). Selection pressures on shrubs may favor the production of fleshy fruits as the perennial woody condition is structurally adapted for the production of high quality fruits that require large amounts of water. In fact, fleshy fruit production is positively selected for at sites with high moisture and soil fertility because the large metabolic costs associated with the production of edible pulp are more likely to be met under these conditions (Willson et al. 1989, Almeida-Neto, et al. 2008, Buitrón-Jurado \& Ramírez 2014). In forests, species with fleshy fruits tend to be understory species, particularly shrubs and small trees (Herrera 1984, French 1991). The higher frequency of shrubs with fleshy fruits compared to tree species might be also related to the relatively small size of shrubs compared to trees: tall trees commonly have dry-wind seed dispersal mechanisms. Low frequencies of fleshy fruits among tree and vine species, and higher frequencies among shrubs have also been associated with dry forests compared to wetter ones (Willson et al. 1989). The high frequencies of dry fruits and the minimal occurrence of fleshy fruits among annual herbs have been found repeatedly (Willson et al. 1989, Possete et al. 2015), and seem to be influenced by the low energetic cost and shorter development period of dry fruits, which are also undemanding of water and energy to complete growth. The strong associations found between 
dry fruits (dehiscent and indehiscent) and herbs may be related to the relatively small plant size, short lived life cycle, and inexpensive fruits.

The most frequent fruit and seed colors were associated with the different life forms and successional stages. Thus, trees and shrubs, mostly from late successional stages, had brown, green, yellow and purple-black fruits (shrubs also produced red fruits). The relationships between life form and fruit color are mainly determined by the links between texture, color and the seed dispersal mechanism. Brown, green and yellow fruits in woody species are associated with dry and fleshy fruits in trees, and mostly fleshy fruits in shrubs. Dry fruits in trees are frequently brown but some species produce green fruits (Knight \& Siegfried 1983, Noir et al. 2002, Selwyn \& Parthasarathy 2006, Yamamoto et al. 2007, Ibarra-Manríquez \& Cornejo-Tenorio 2010). On the other hand, the fleshy fruits found in some tree species are green or yellow and usually dispersed by mammals (Janson 1983, Knight \& Siegfried 1983, Voigt et al. 2004, Galetti et al 2011). Previous studies indicate that purple-black and red are the main fruit colors for tree species (Willson \& Thompson 1982, Janson 1983, Knight \& Siegfried 1983, Wheelwright \& Janson 1985, Burrows 1994, Voigt et al. 2004, Ibarra-Manríquez \& Cornejo-Tenorio 2010), most likely because birds are the most common dispersal agents in the canopies of tropical forests (Wheelwright \& Janson 1985). In contrast, herbaceous species, frequently from pioneer successional stages, generally produce dark (black and brown) fruits, although some pioneers have purpleblack fruits. Dark fruits in herbaceous species can be explained by the associations between dry, dehiscent and indehiscent fruits, and their dispersion mechanisms which may be abiotic, or biotic through non-frugivorous animals: granivochory or epizoochory. Epizoochory is a well-known dispersal syndrome for herbaceous colonizing species (Graae 2002, Devlaeminck et al. 2005), and seed dispersal by granivores and wind is frequently found for herbs growing in disturbed areas (Ramírez 2005, Hilje et al. 2015).

The absence of a clear relationship between seed color, life form and successional stage is probably due to the fact that seed color in many indehiscent fruits is little linked to environmental and biotic factors, unlike seed color in dehiscent fruits which are therefore under stronger selection pressures. Brown was the most common color for seeds in plant species of all life forms and the two successional stages considered. Other associations observed among the most common seed colors, life forms and successional stages were: beige and black for perennial herbs, and white for annual herbs (generally pioneer species). In contrast, orange and white+black seeds found in woody and late successional stage species may be related to specialized frugivorous dispersal mechanisms (Cazetta et al. 2009).

Epiphytes are perennial herbs that grow on a host plant and tend to have dry-dehiscent fruits and brown seeds. Dry-dehiscent fruits such as capsules are frequently associated with wind dispersal mechanisms (Burrows 1994) and are often found in epiphytes (Miller 2005). It is also likely that there is some taxonomic effects as wind dispersed species are common in epiphytic Bromeliaceae and Orchidaceae (Benzing 1990; Hughes et al. 1994; Mori \& Brown 1994, Miller 2005). The abundance of capsules in epiphytic species may be related to: 1- wind dispersal, because they enable the release of light seeds during the dispersal period (Madison 1977, Hughes et al. 1994), 2- the fact that wind-dispersal of capsule-derived light (in weight) seeds is an appropriate dispersal mechanism for epiphytes due to their position in the vegetation strata
(Madison 1977, Hughes et al. 1994), 3- the distribution of epiphytes in the highest vegetation strata as regards the vertical organization of the plant communities where they are found, which represents an adaptation for wind dispersal (Madison 1977, Kelly 1985) and 4- the fact that epiphytic species may be physiologically limited because of the restricted availability of water (Zotz \& Hietz 2001) and capsules could be an adequate inexpensive fruit type under these conditions.

In contrast, parasitic-hemiparasitic species had predominantly fleshy fruits. Most of the parasitic-hemiparasitic species with indehiscentfleshy fruits belong to the Santalaceae (Miller 2005, Viscaceae (Kuijt 2005) and Loranthaceae (Kuijt 2001)), which are phylogenetically related (APG IV 2016) and produce green seeds. Fleshy fruits in parasitic-hemiparasitic species are also associated with: 1- nutritional dependency on the host plant, which seems to enable the production of expensive fleshy fruits that are similar to the types of fleshy fruits found in woody species (Willson et al. 1989, Carpenter et al. 2003, Bolmgren \& Erikksson 2010, Buitrón-Jurado \& Ramírez 2014). Fleshy fruit production is positively selected for under high moisture conditions as the high metabolic costs associated with the production of edible pulp can be met (Willson et al. 1989, Almeida-Neto, et al. 2008, BuitrónJurado \& Ramírez 2014). 2- The vertebrate dispersal syndrome which is a common dispersal syndrome in parasitic-hemiparasitic species (Hughes et al. 1994). Parasitic mistletoes tend to show host specificity (Nadkami et al. 2001), and show directionality in the dispersal process towards the exposed branches of suitable host plants. Green seeds are common in the parasitic-hemiparasitic families, Santalaceae and Loranthaceae (Miller 2005). Green seeds in parasitic-hemiparasitic species also seem to be related to the photosynthetic capacity of the seeds and the recruitment process on bare woody surfaces. In order to survive parasitic plants must be dispersed to the limbs of suitable host plants, and once there they produce a haustorium which penetrates the host during establishment. This process may be enhanced by green seeds and their photosynthetic capacity. Developing green fruits may contribute a major proportion of their own photosynthate (Bazzaz et al. 1979) suggesting that mature green seeds may also contribute photosynthetically to their maintenance and consequently may be viable for longer. Mature green fruits may also avoid frugivory by crypsis, or be involved in more specific plant-animal interactions.

Morphological fruit types are noticeably correlated with successional stages. Dry fruits occur more frequently in pioneer species and fleshy fruits tend to be abundant in late successional stage species. Many late successional stage woody species produce berries or drupes. In contrast, herbs from disturbed areas are associated with achene and caryopsis (anthecetum) fruit types. These trends are in line with the associations found between herbs with dry fruits growing in open habitats (Arbeláez \& Parrado-Rosselli 2005, Lorts et al. 2008, Bolmgren \& Erikksson 2010), and between fleshy fruits produced by trees and shrubs growing in closed habitats and at the climax end of a successional sequence (the latter being less frequent in disturbed habitats) (Herrera 1984, Willson et al. 1989, Carpenter et al. 2003, Lorts et al. 2008, Bolmgren \& Erikksson 2010, Buitrón-Jurado \& Ramírez 2014). In addition, indehiscent fruits in natural habitats could be related to a more stable environment, where fleshy-indehiscent fruits predominate (Opler et al. 1980). In contrast, dehiscent fruits were more common than indehiscent fruits in disturbed habitats, which correlates with the morphological adaptions (multi-seeded dry fruit) of some colonizing species (Arbeláez 
\& Parrado-Rosselli 2005). In summary, fleshy-indehiscent fruits occur predominantly in undisturbed areas, while dehiscent and indehiscent dry fruits are more abundant for pioneer species growing in disturbed areas.

The relationships between life form and morphological fruit type also include the carbon metabolism pathway employed by plant species. Thus $\mathrm{C}_{4}$ species are herbaceous (Medina 1995, Ramírez \& Briceño 2015) and are mainly associated with caryopsis (anthecetum and pseudoanthecium) fruit types. Most of these plant species grow in savannas and disturbed areas (Medina 2002, Ramírez \& Briceño 2015). The most abundant fruit types in $\mathrm{C}_{4}$ and CAM species are taxonomically influenced. As previously mentioned, $\mathrm{C}_{4}$ species are herbs and produce principally dry-indehiscent one-seeded fruits. For example, caryopsis is a classic morphological fruit type of Poaceae (Silberbauer-Gottsberger 1984, Amaral et al. 2013). In contrast, multi-seeded dry-dehiscent, capsule, fleshy-indehiscent, and acrosarcum fruit types are typical of CAM and succulent species, mostly from the Cactaceae (Spjut 1994). Moreover, most $\mathrm{C}_{4}$-herbaceous species grow in disturbed habitats (Ramírez \& Briceño 2015) and their caryopses are mainly dispersed by epizoochory and anemochory (Silberbauer-Gottsberger 1984, Amaral et al. 2013). All these attributes seem to point towards a general colonizing strategy of some herbaceous species. In contrast, the multi-seeded fruits of succulent-CAM species exhibit diverse morphological fruit types, and consequently varied fruit strategies. For example, pink fruits common in succulent-CAM species are dispersed by animals and well represented in the Cactaceae.

\section{Fruit types and fruit phenology}

The most abundant morphological fruit types, both according to Gray (1877) (e.g. achenes, berries, drupes, loculicidal capsules, and schizocarps), and Spjut (1994) (e.g. baccas, drupes, loculicidal capsules, and septicidal capsules) exhibited seasonal changes in their unripe and ripe fruit phenologies, especially during the rainy-dry transition period. This agrees with previous studies undertaken in different plant communities (Oliveira \& Moreira 1992, Jordano 1993, Batalha \& Martins 2004, Freitas et al. 2013). Fruit phenology during the rainy season and rainy-dry transition period may signify that this is the optimal time for dispersal and/or ripening. The variety of morphological fruit types found during these periods also suggests that the ripening and dispersal of dry and fleshy fruits is associated in some way with the rainy season. Ripe, fleshy fruits are dispersed by animals and are frequently associated with the rainy season (Oliveira \& Moreira 1992, Batalha \& Martins 2004). On the other hand, the relationship of dry fruits (capsules, achenes, and schizocarps) to the dry season and rainy-dry transition period could be due to the diverse adaptations they have for dispersion by granivorous animals, and ballistic, and wind dispersal. Other factors that may influence the seasonality of diverse fruit types during the rainy season and rainy-dry transition period are irradiance, which could affect fruit development times (Zimmerman et al. 2007), and the synchronization of fruiting and dispersal with the onset of the rainy season to maximize the chances of seed germination and seedling establishment (Oliveira 1998).

Dry fruits were common in ecosystems with low annual precipitation such as the seasonal Caatingas (Sobral \& Machado 2001, Silva \& Rodal 2009, Silva et al. 2013). Ripe and unripe dry fruit phenologies associated with the dry season may represent a strategy related to the relatively low cost of dry fruits. Dry fruit production during the dry season may be also related to abiotic seed dispersal. Thus, many wind-dispersed winged fruit types such as samara and samarium are produced during the dry season (Wikander 1984, Devineau 1999, Cortés-Flores et al. 2019). The synchronization of dry fruits with the dry season may also be phylogenetically constrained (Bulhão \& Figueiredo 2002). The ripe and unripe fruit phenologies of dry fruit species unusually associated with the rainy season suggest that the production of these types of fruits is in some way independent of the season, and that the contribution of the rains to the ripening process and ripe fruit phenologies is only significant in a few cases. The presence of unripe caryopsis and silique (Gray 1877), and anthecetum, ceratium and coccarium (Spjut 1994) fruit types during the rainy season suggest that the ripening process of these predominantly dry fruits is, nevertheless, affected by the rains, or alternatively, it is flowering that is mainly associated with the rainy season, which is itself closely related to unripe fruit phenology during this period. Dry fruits associated with an herbaceous life form can also be related to fruit phenology: herbs, which produce predominantly dry fruits, tend to fruit during the rainy season (Ramírez 2009, Ramírez \& Briceño 2011, López \& Ramírez 2013). In addition, unripe dry-fruit phenology shows that developmental processes are related to the presence of rain and thus probably depend on an adequate water supply to complete the ripening phase (Lombardini \& Rossi 2019). Most of these dry fruits ripen during the rainy-dry transition period or the dry season, which could represent adaptations to wind and granivorous seed dispersal (Cortés-Flores et al. 2019).

The ripe and unripe fruit phenologies of fleshy-fruited species are positively associated with the rainy season, although uncommon occurrences of fleshy fruit during the dry season have been previously recorded (Oliveira \& Moreira 1992, Jordano 1993, Batalha \& Martins 2004). The abundance of fleshy fruits during the rainy season seems to agree with the elevated costs associated with their production, and the fact that the quality of fleshy fruits is related to their water content. In addition, most fleshy fruits are ripe indehiscent fruits, and are produced during the rainy season due to positive selection for a high moisture environment (Willson et al. 1989, Mclaren \& Mcdonald 2005, AlmeidaNeto et al. 2008, Buitrón-Jurado \& Ramírez 2014). Thus, unripe fleshy fruit phenology during the rainy season seems to be related to the ripening process of expensive fleshy fruits. Furthermore, the presence of unripe fleshy fruit during the rainy season could be associated with woody life forms because the structural patterns of these plant species mean that they are comparatively less limited by low water and nutrient availability (Rathcke \& Lacey 1985).

\section{Fruit phenology and fruit and seed colors}

Unripe and ripe dark (black, brown, green, or purple-black), fruits were common during the rainy-dry transition period. Unripe red or yellow fruits were also abundant during this time. Brightly colored fruits, however, are more frequent on average during the rainy season (Wheelwright \& Janson 1985). This seems to correspond to the ripening of red and yellow fruits before the rainy season, and agrees with the high frequencies of fruits with these colors during the rainy season. The ripening of bright fleshy fruits during the rainy season can be mostly explained by the association between bright colors, fleshy fruits, and animal dispersal. As regards seed colors, no specific associations were observed, although beige, black, brown, green, orange, and white were the most abundant seed colors during the rainy-dry transition period. 
Large-scale comparisons suggest that fruit color, rather than other morphological and chemical fruit traits, reflects the selection pressures exerted by different frugivore assemblages (Voigt et al. 2004). Probably, seed color diversity derived from contrasting textures, dehiscence and combinations of these attributes could result from factors independent of reproductive phenology. Seeds from dehiscent and indehiscent fruits differed according to the mechanisms of protection, dispersal, physiology and recruitment. Multi-species analysis of fruit types and seed color combinations showed a highly diverse assemblage, and suggests that seed color is independent of fruit phenology

\section{Conclusion}

The taxonomic structure may provide similar insights as the phylogenetic approach (e.g. Corbelli et al. 2015, Fan et al. 2017). In this context, the influence of large taxonomic groups as families and orders may, in some cases, influence the main conclusions derived from the results obtained. The four most common seed color categories were generally associated with the most common fruit colors. Particular associations between fruit morphology and fruit and seed colors could be taxonomically influenced. For instance, most of the rhexocarpic fruits are brown, dehiscent, and their seeds are frequently brown; a large number of these plant species belong to one of the most frequent order found in the sample examined (22.4\% of Fabales; N. Ramírez \& H. Briceño, in preparation). However, the more representative associations were mainly found for dry fruits: brown color with a loculicidal capsule fruit type, which may be widely represented in a variety of lineages. The largest groups represented in the sample examine [ Lamids (17.4\%), Malvids (21.10\%), and Fabids (27.26\%), N. Ramírez \& H. Briceño, in preparation] contain many mixed families producing dry and fleshy fruits. Therefore, dry-dehiscent fruits and their associations with brown seeds are not necessarily influenced taxonomically in all cases. Fleshy fruits were somewhat less specific as regards color, and the only significant associations found were that drupes and berries (baccas) were usually purple-black, with brown or beige seeds. Such associations come from different lineages and taxonomic groups (Rubiaceae, Solanaceae, Myrtaceae, Melastomataceae, Humiriaceae, Passifloraceae) and suggest no evident taxonomic constraints. Similar conclusion has been previously proposed for fleshy fruits (Janson 1983; Willson et al. 1989). Asymmetries in the level of specialization, where less frequent fruit and seed colors tended to be related to the most common fruit types, and seem variations without taxonomic or phylogenetic consequences.

Morphological fruit types have attributes that are closely related to different colors and diverse functional plant traits. Thus, trees were associated with fleshy and dry fruits, shrubs with fleshy fruits, and herbs with dry-dehiscent and dry-indehiscent fruits. Dry fruits occurred more frequently in pioneer species and late successional stage plants, mostly woody species, tended to have fleshy fruits. Such relations seem to be largely independent of taxonomic effects; however, some specific correlations are influenced taxonomically. The abundance of plant families containing a large variety of attributes, called mixed families, which are well-represented in the three largest groups found in the sample examine (see above, N. Ramírez \& H. Briceño, in preparation) could be provide independence taxonomic. Our results agree with previous study where mixed families, species producing non- fleshy fruits tend to be herbs or vines growing in open and/or frequently disturbed habitats. In these families, fleshy fruits are usually produced by woody plants (trees and shrubs) in closed, less frequently disturbed habitats (Bolmgren \& Erikksson 2010). Additionally, the distribution of plant families producing fleshy fruits does not differ significantly among the five lineages recognized in the APG (basal angiosperms, monocots, basal eudicots, asterids, and rosids) (Fleming \& Kress 2011). On the other hand, the $\mathrm{C}_{4}$ species are herbs and produce mainly dry-indehiscent, one-seeded fruits, which are influenced taxonomically. Most of these plant species are Poaceae and grow in disturbed areas and their fruits and seeds are influenced taxonomically since Poales represent $27.6 \%$ of perennial herbs in the sample examined (N. Ramírez \& H. Briceño, in preparation). Epiphytes usually had dry-dehiscent fruits and brown seeds (Orchidaceae and Bromeliaceae) and predominantly fleshy fruits in parasitic-hemiparasitic species (Santalaceae and Loranthaceae) were taxonomically influenced. However, dry-dehiscent fruits and brown seed in epiphytes belong to two different orders and clades (see APG 2016). The relationships among phenology, morphology and color of fruits, where dry fruit were associated with the dry season, and fleshy fruit species were positively associated with the rainy season may be not taxonomically influenced because seasonality is mainly related with life forms and fruit texture (see above). Thus, the presence of ripe bright-fleshy fruits during the rainy season was mostly explained by the association between bright color, fleshy fruits, woody life form, water availability, and animal dispersal. Moreover, herbaceous species, with dry fruits are also associated with the rainy period. By the contrary, the occurrence of dry fruits during the dry period is mainly explained by the association between dry fruit, woody life form and abiotic dispersal.

\section{Supplementary Material}

The following online material is available for this article: Appendix S1 - Distribution of Gray (1877) and Spujt (1994) fruit types according to fruit color. Appendix S2 - Relationship between fruit and seed colors. Percentages are relative values to each raw, except total fruit colors. Appendix S3 - Distribution of Gray (1877) and Spujt (1994) fruit types according to seed color.Appendix S4 - Number and percentage of Gray (1877) and Spjut (1994) fruit types, fruit color, and seed color according to functional groups. Figure S1 - Bipartite graph showing the links between morphological fruit types

\section{Acknowledgements}

The authors would like to thank F. Osborne for comments on the first draft of the manuscript. The authors are indebted to all those people who made it possible to complete this research, especially to O. Hokche, M. López, W. Duran, G. Leal, Y. Brito, D. Vázquez, L. Lemus-Jimenez, C. Grasses, I. Jaimes, L. Rodríguez, and A. Seres. This research was partially supported by BID-CONICIT, Fundacite Guayana, CONICIT, and the Consejo de Desarrollo Científico y Humanístico de la UCV. We wish to express our gratitude to the people of the Autoridad Gran Sabana (CVG), the Estación Biológica de Los Llanos and the Navy Base of Mamo district (C.A.N.E.S.) - Vargas State, for letting us makes use of their onsite facilities. Thank to J. Delgado, J. Grande, G. Colonnello, C. Aranguren, A. Villareal, K. Garcia and B. Gil for let us use their fruit photographs. 
Ramírez, N. et al.

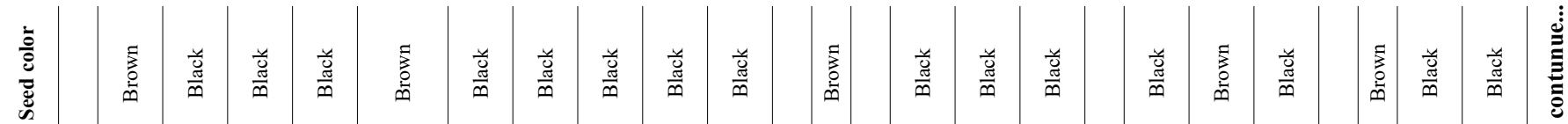

年

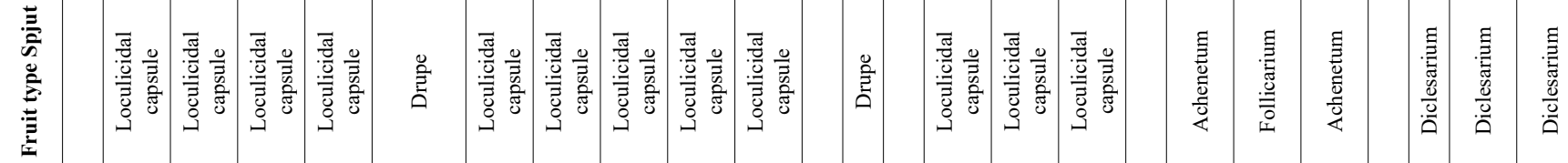

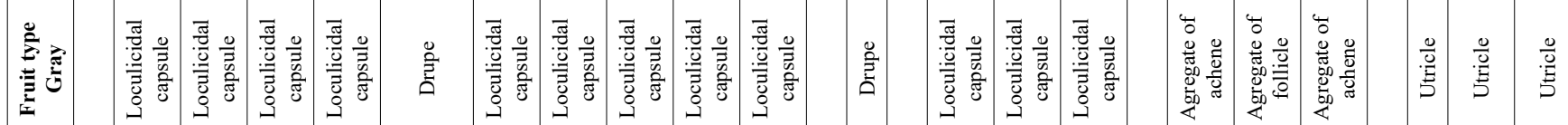

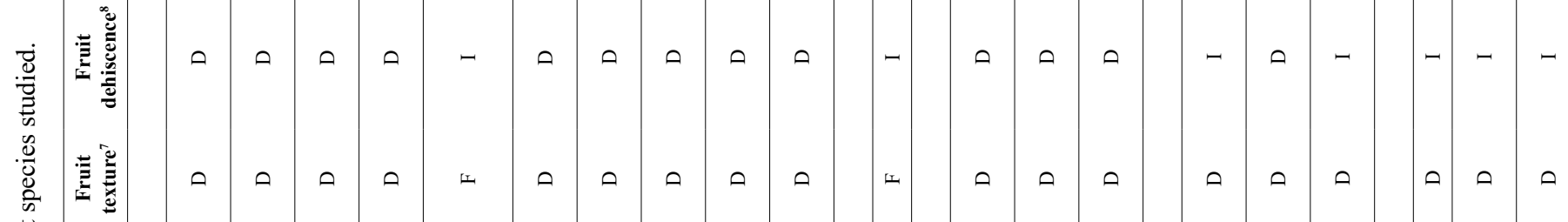

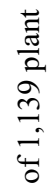

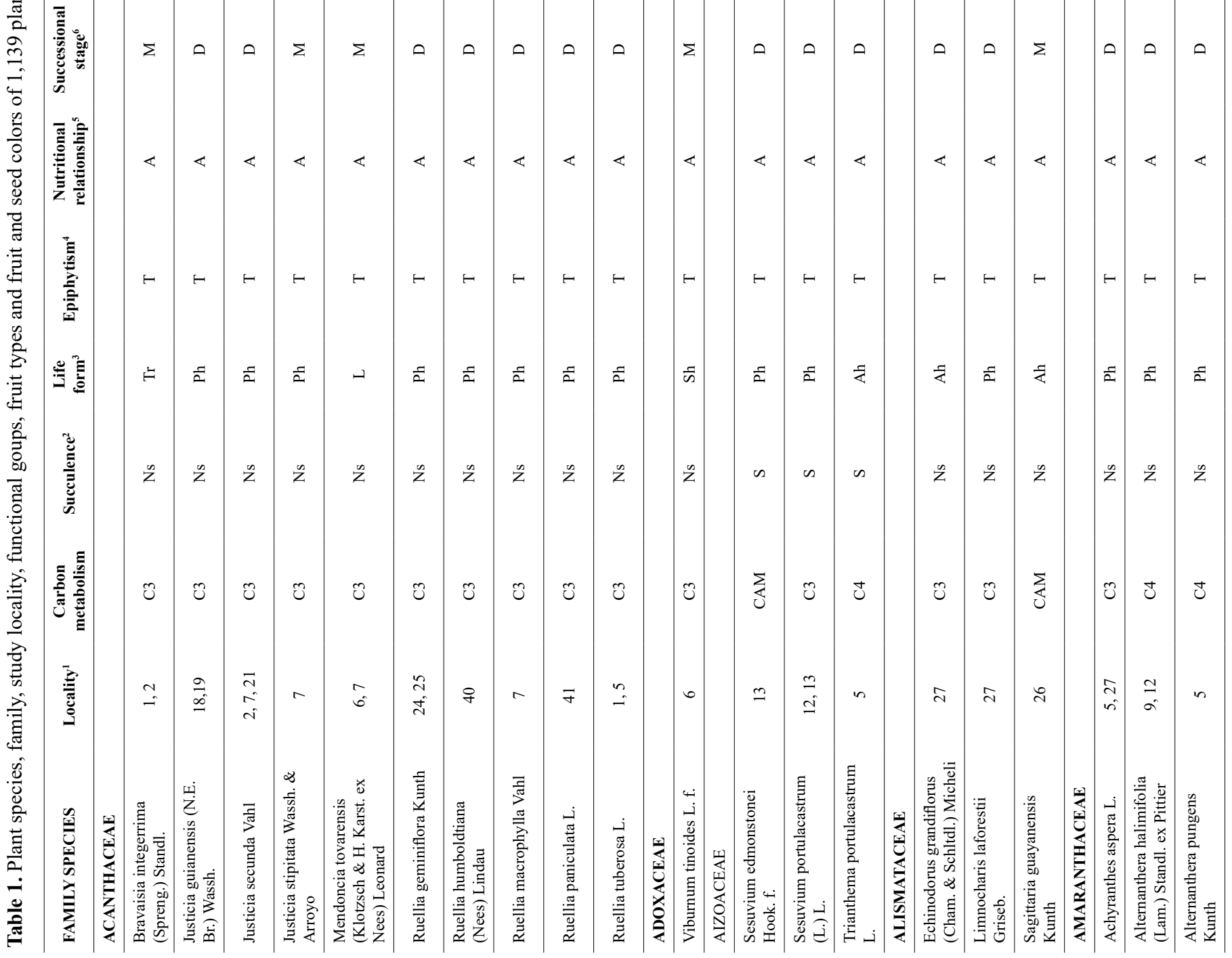




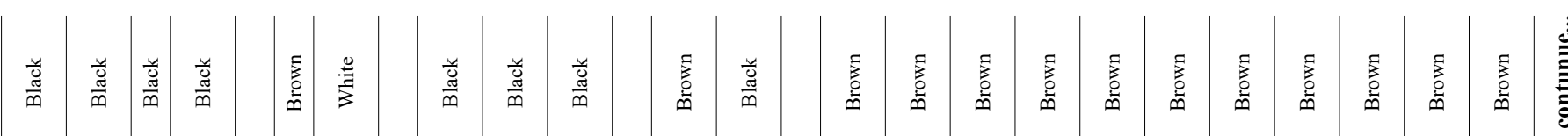

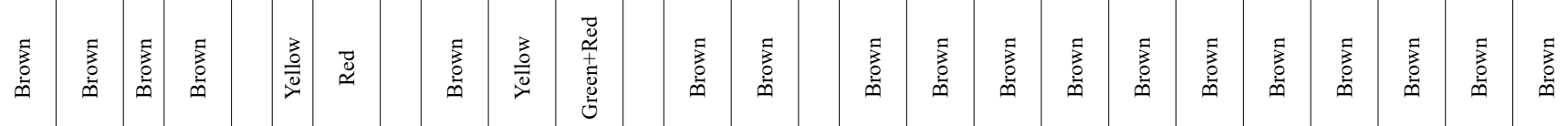

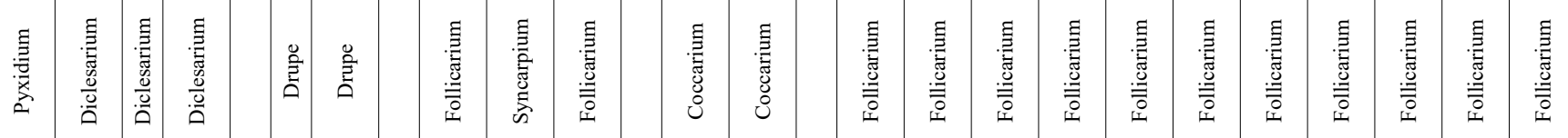

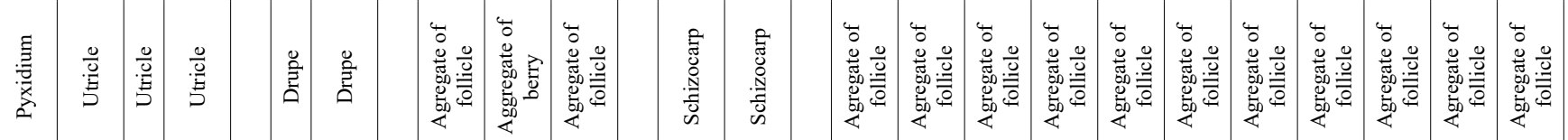

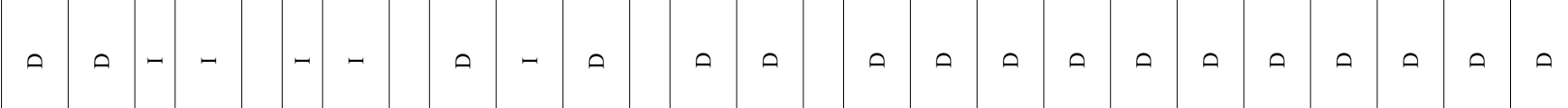
- 0 - 0 ш ш

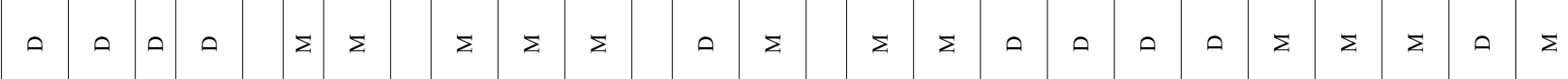

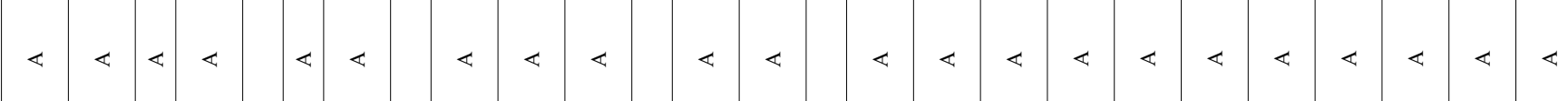

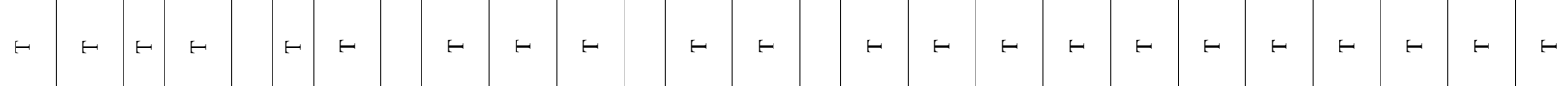

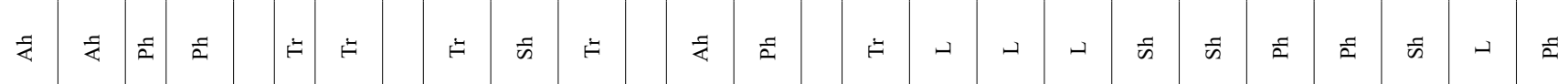

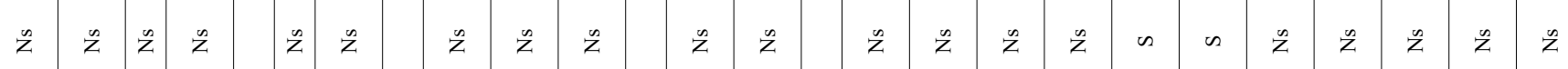

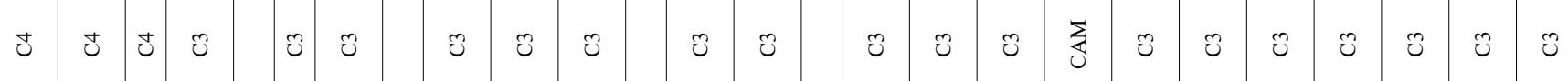

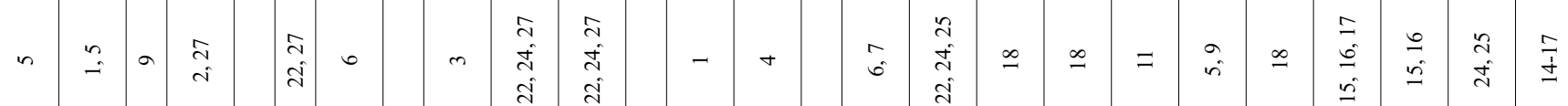

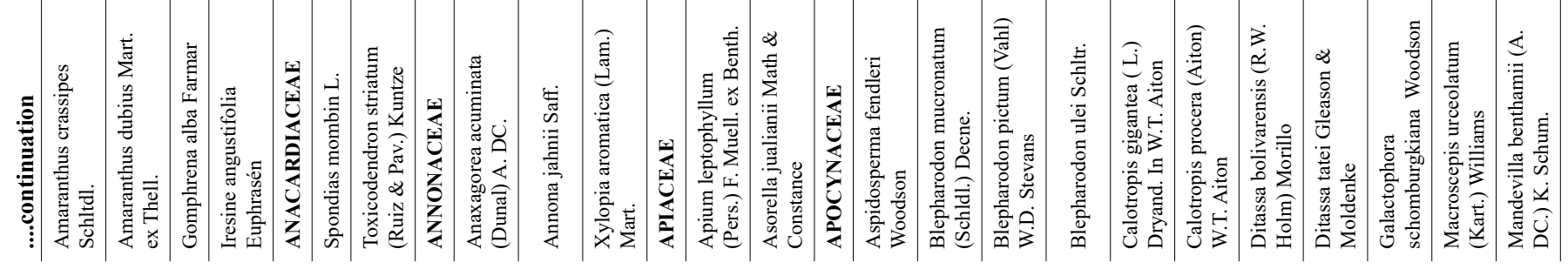


Ramírez, N. et al.

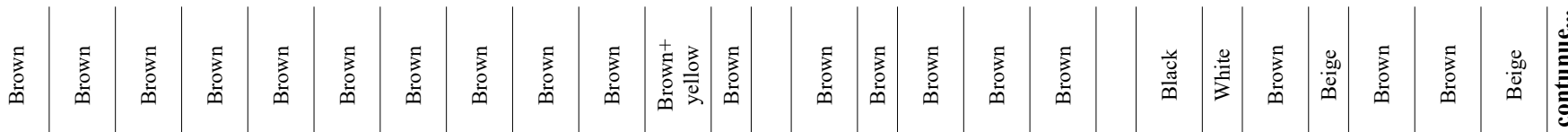

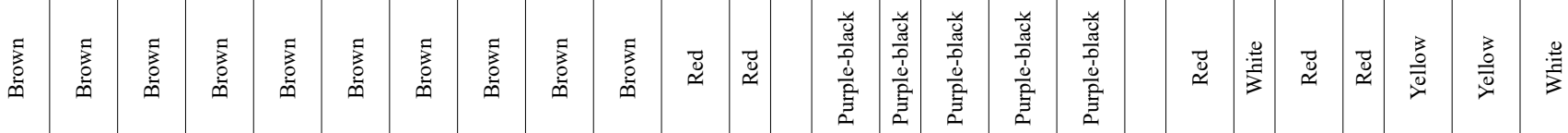

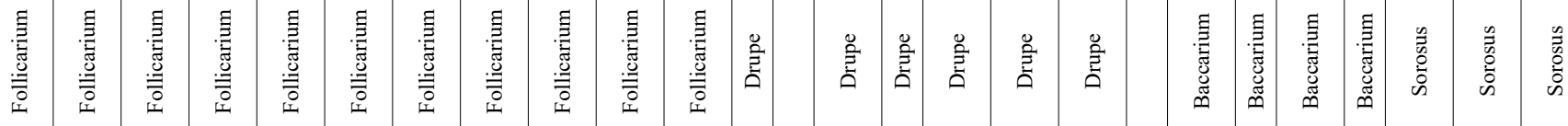

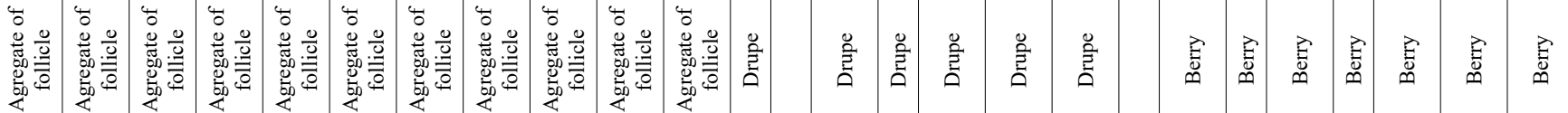
$\therefore \quad$ ○ ○

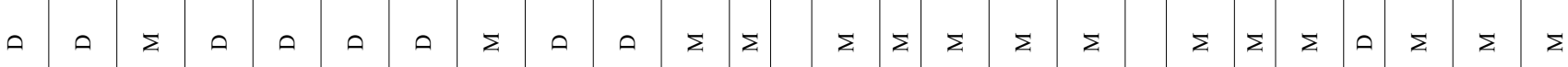

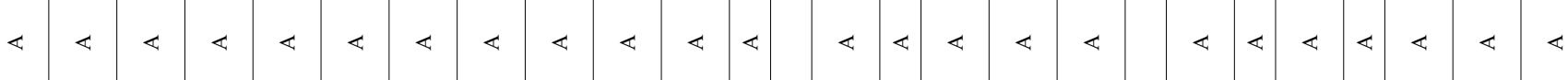

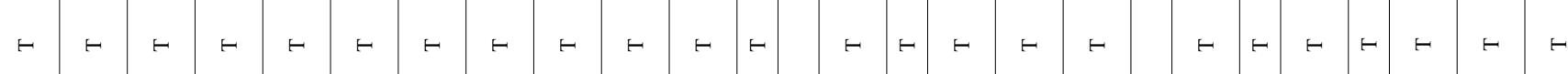

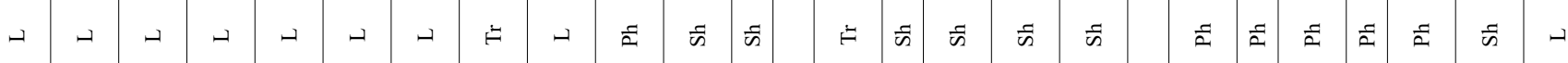

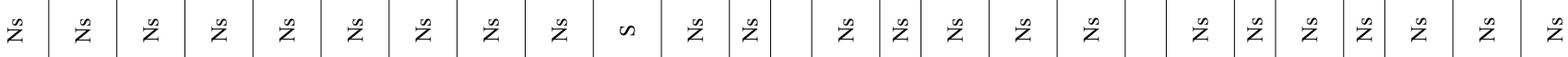

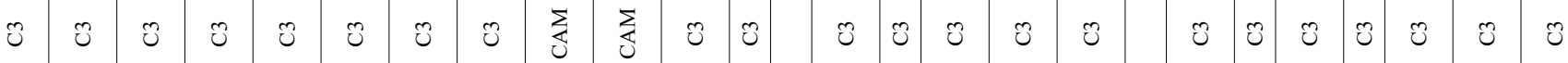

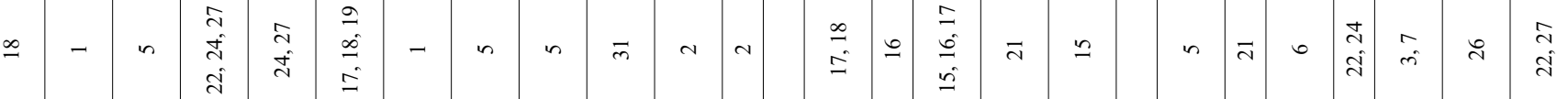

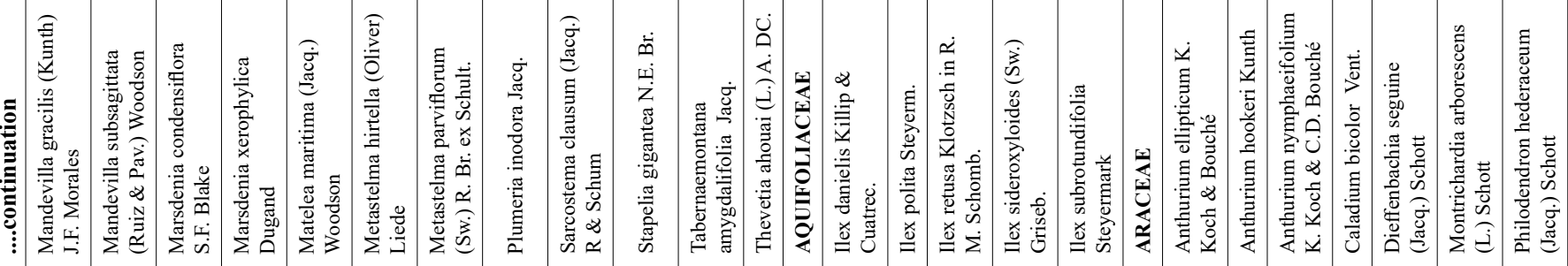




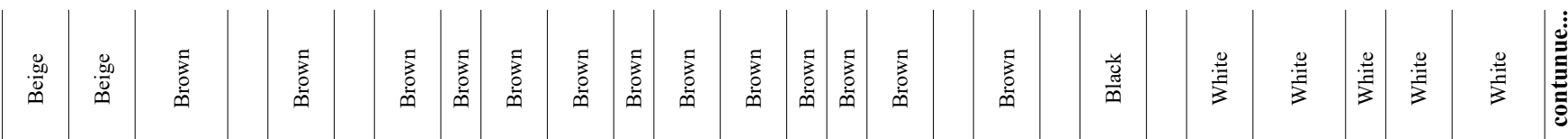

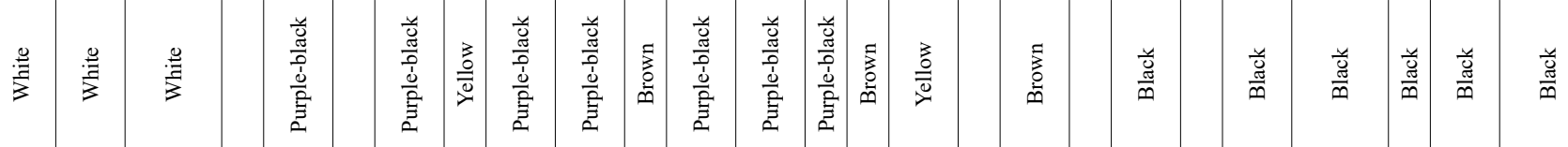

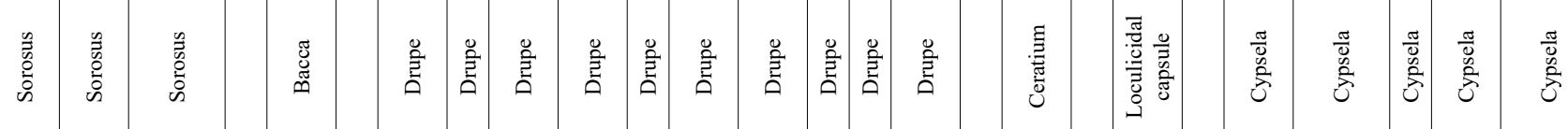
至

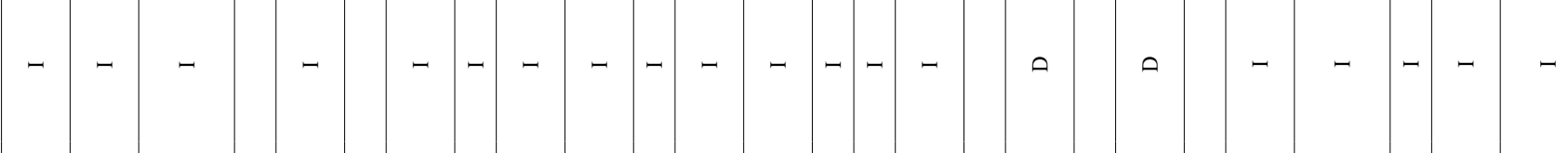

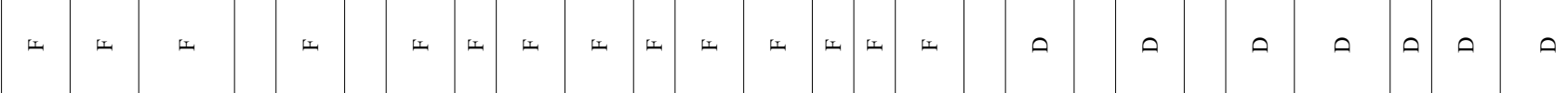

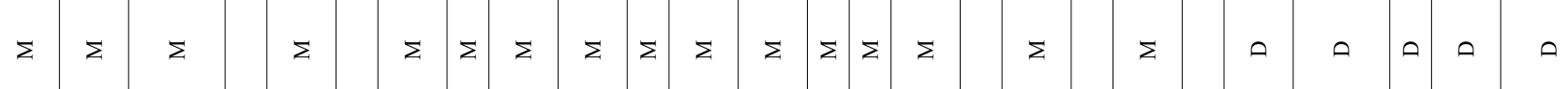

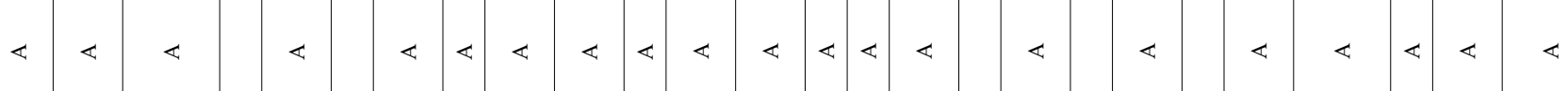

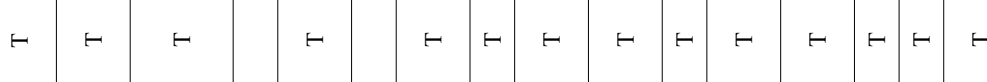

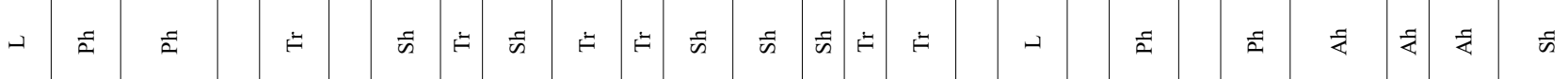

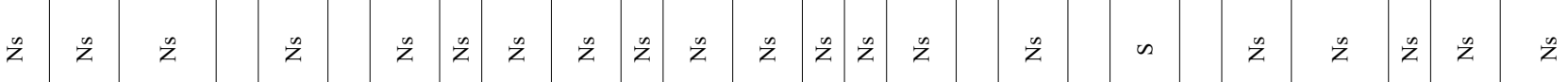

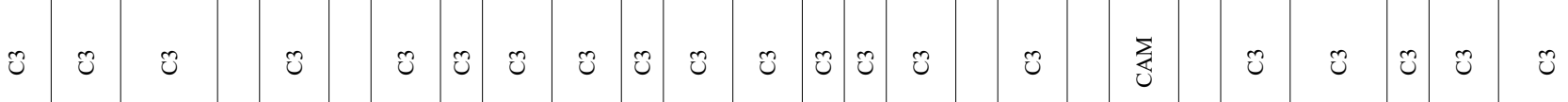

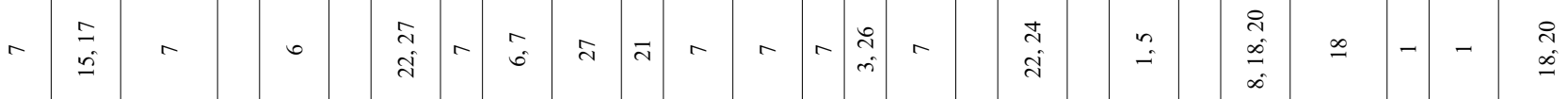

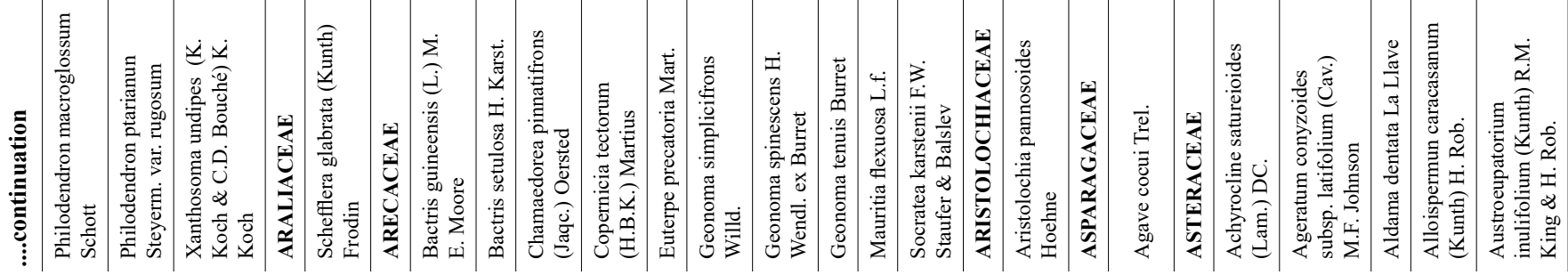


Ramírez, N. et al.

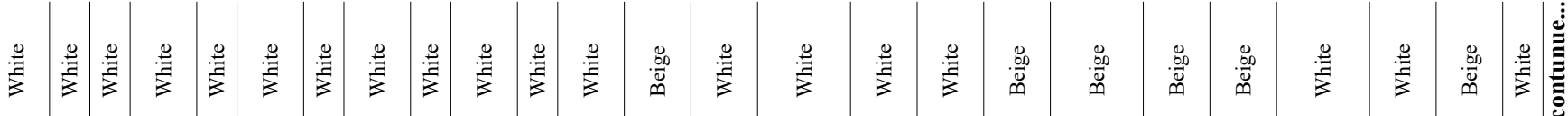

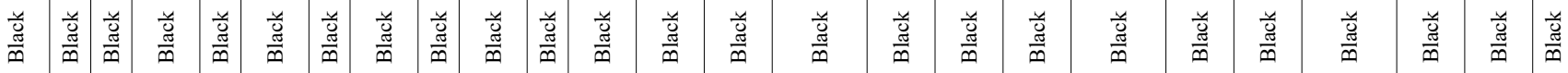

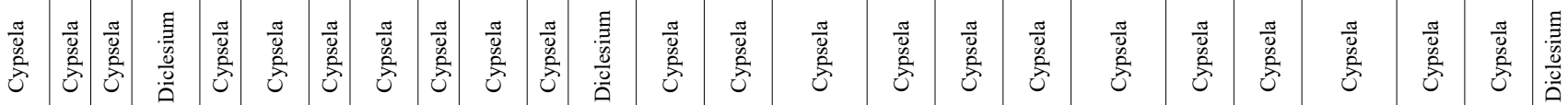

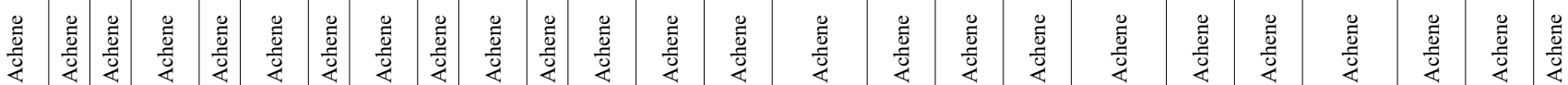

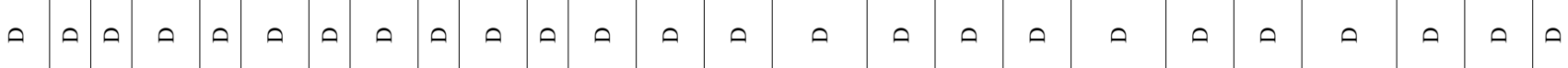

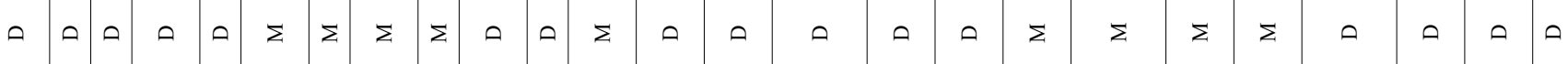

$<<<<<<<<<<<<<<<<<<<<<<<<<<<<$

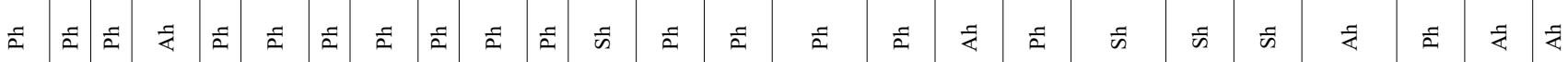

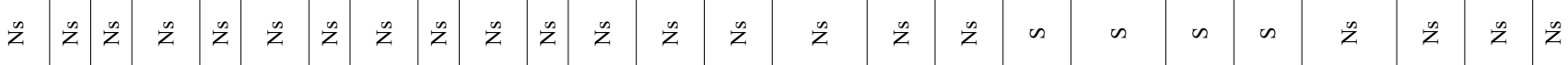

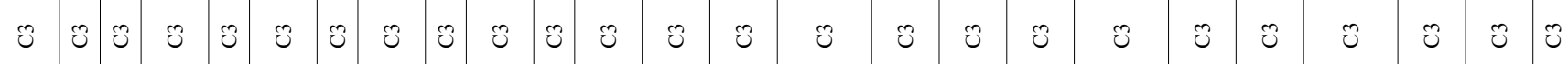

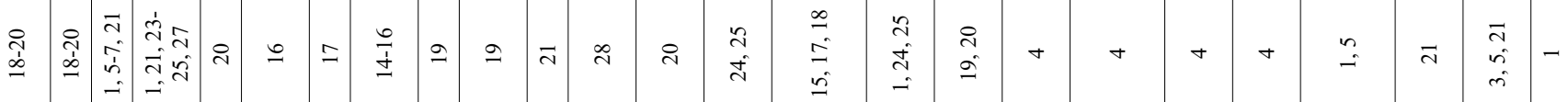

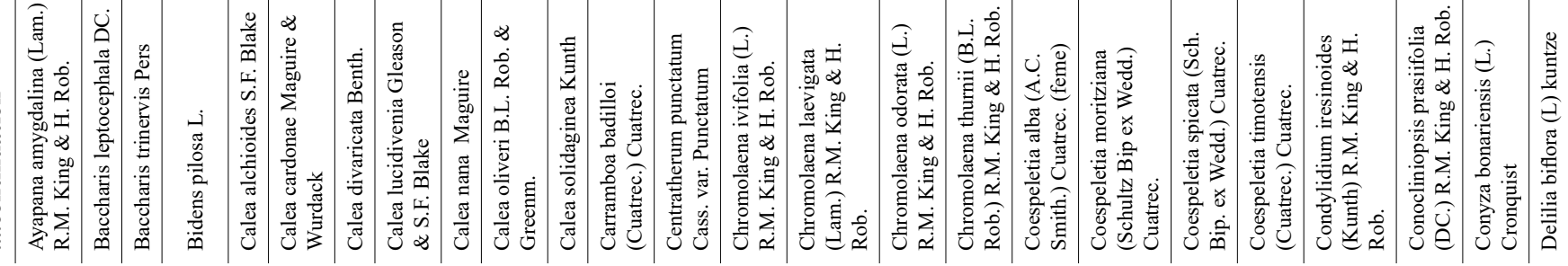




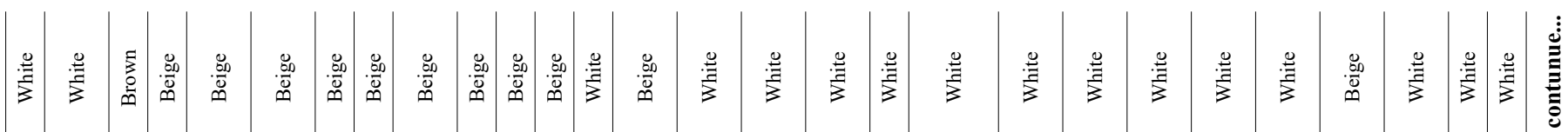

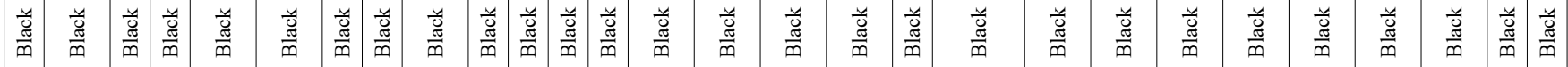

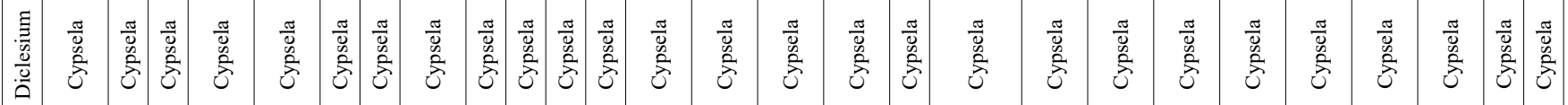

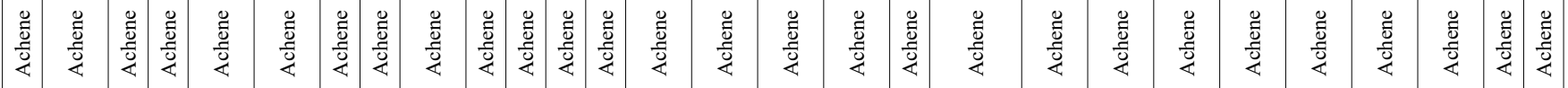
○ $ค$ ค

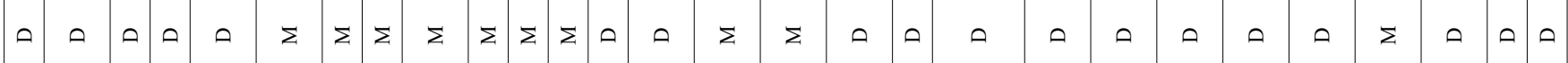

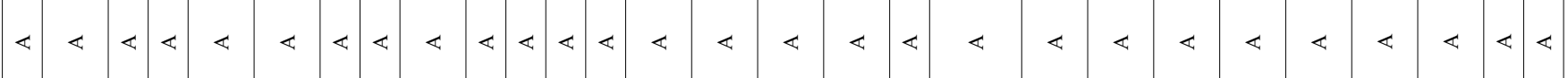

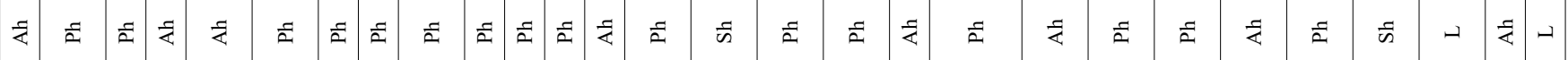

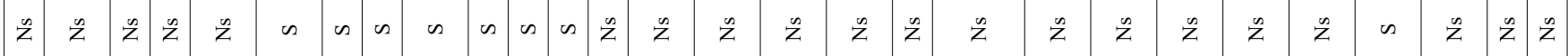

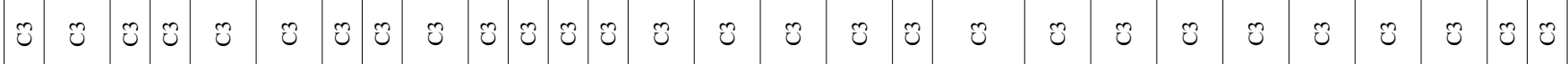

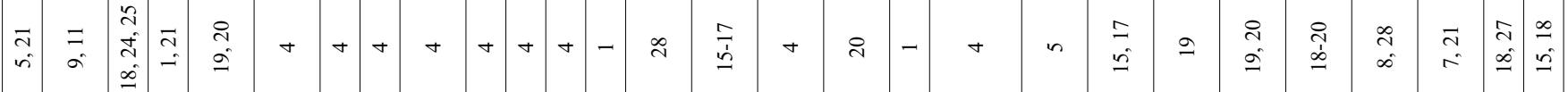

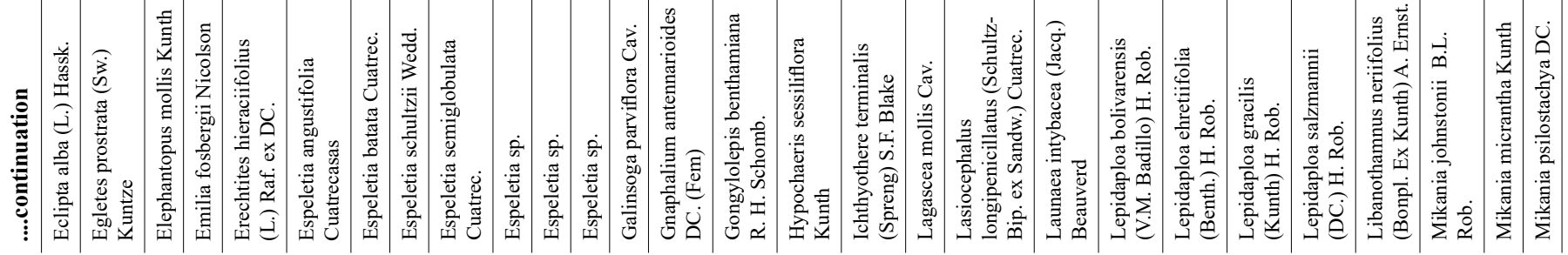


Ramírez, N. et al.

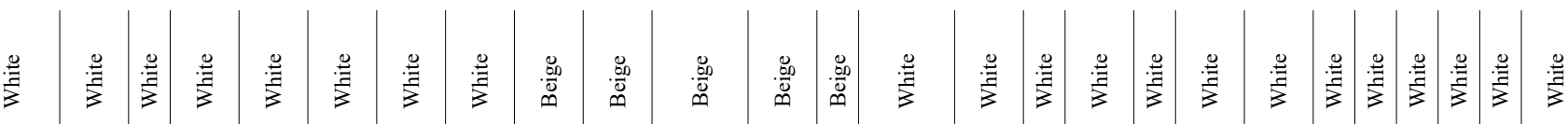

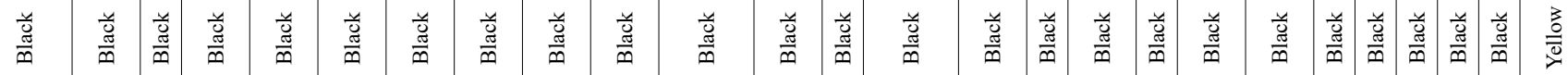

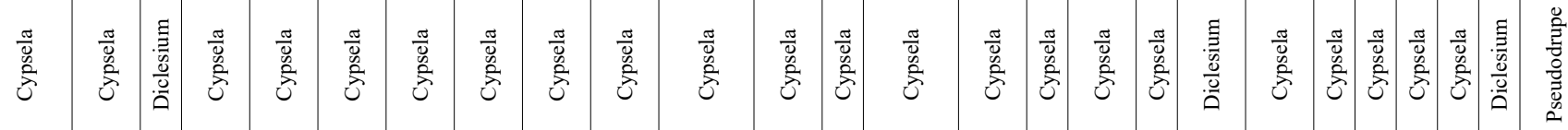

\begin{tabular}{l|l|l|l|l|l|l|l|l|l|l|l|l|l|l|l|l|l|l|l|l|l}
0 \\
$\frac{0}{0}$
\end{tabular}

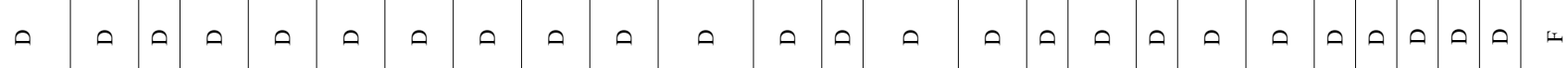

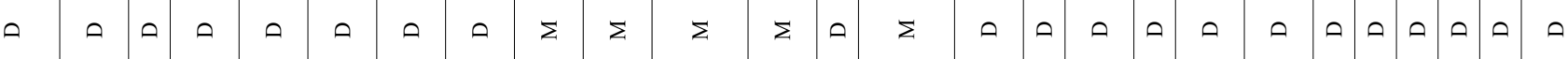

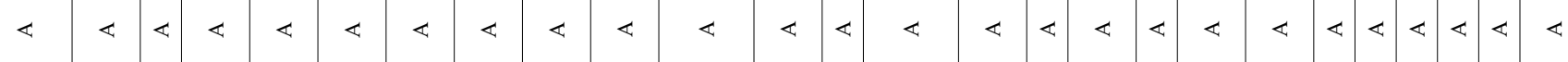

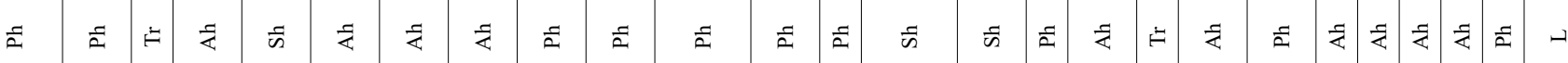

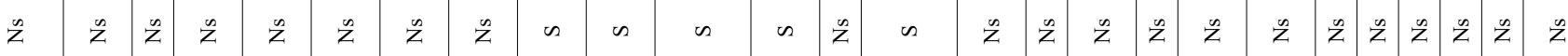

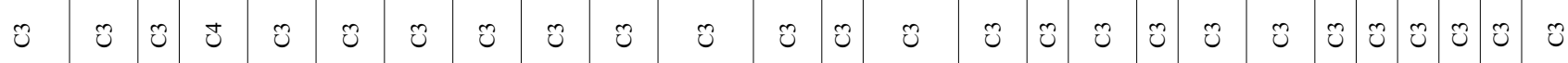

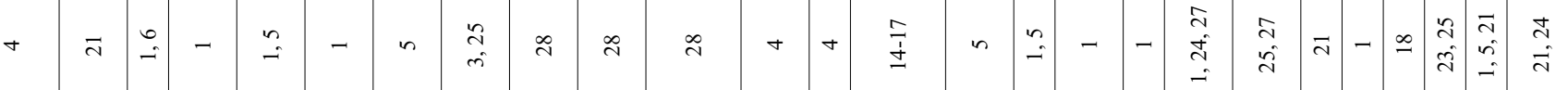

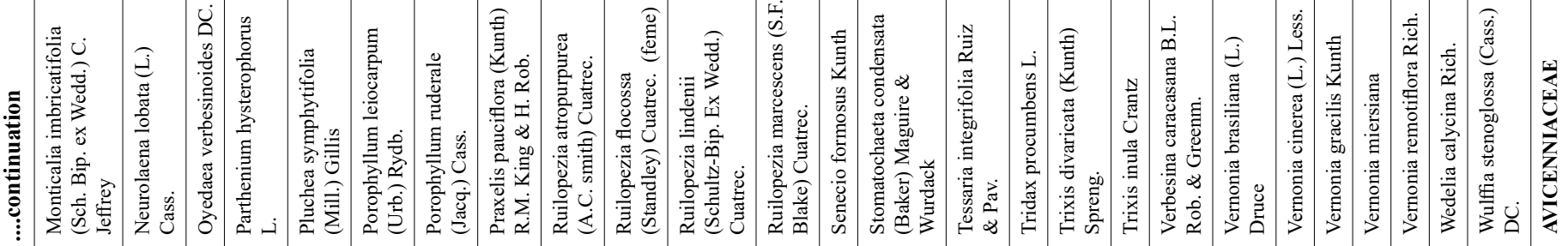




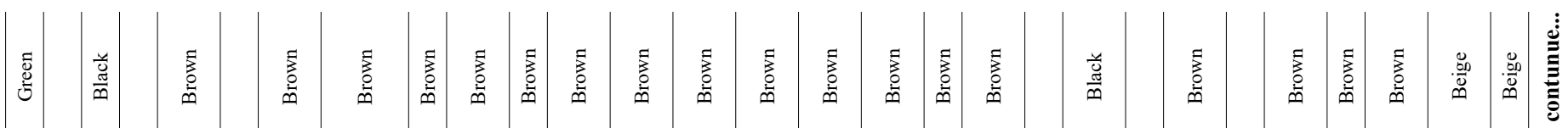

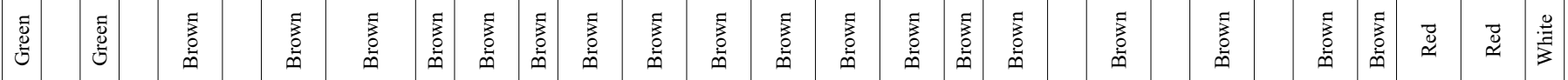

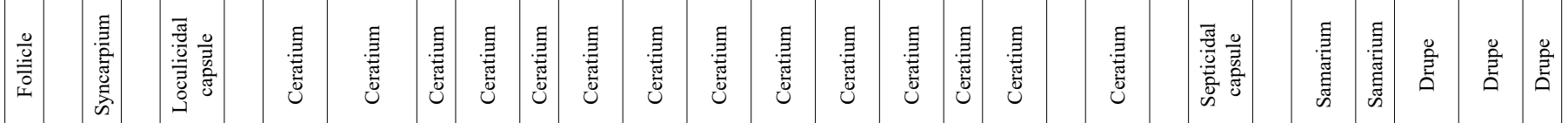

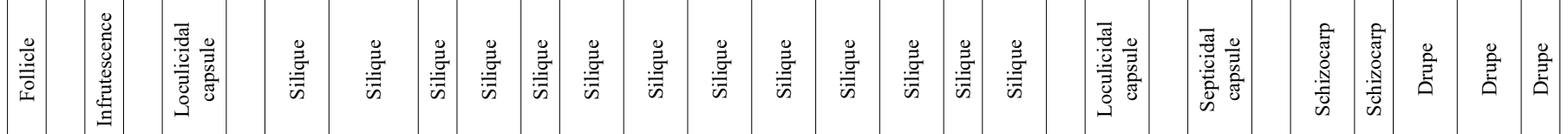
ค - $\quad$ ○ $\quad$ ×

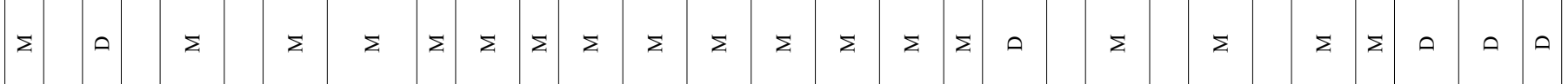

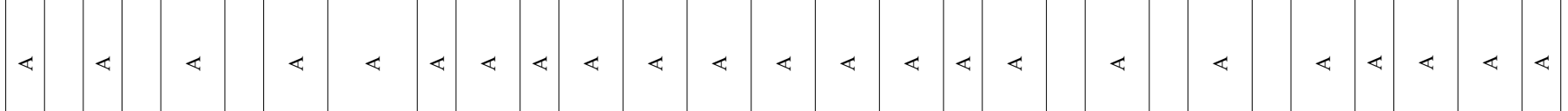

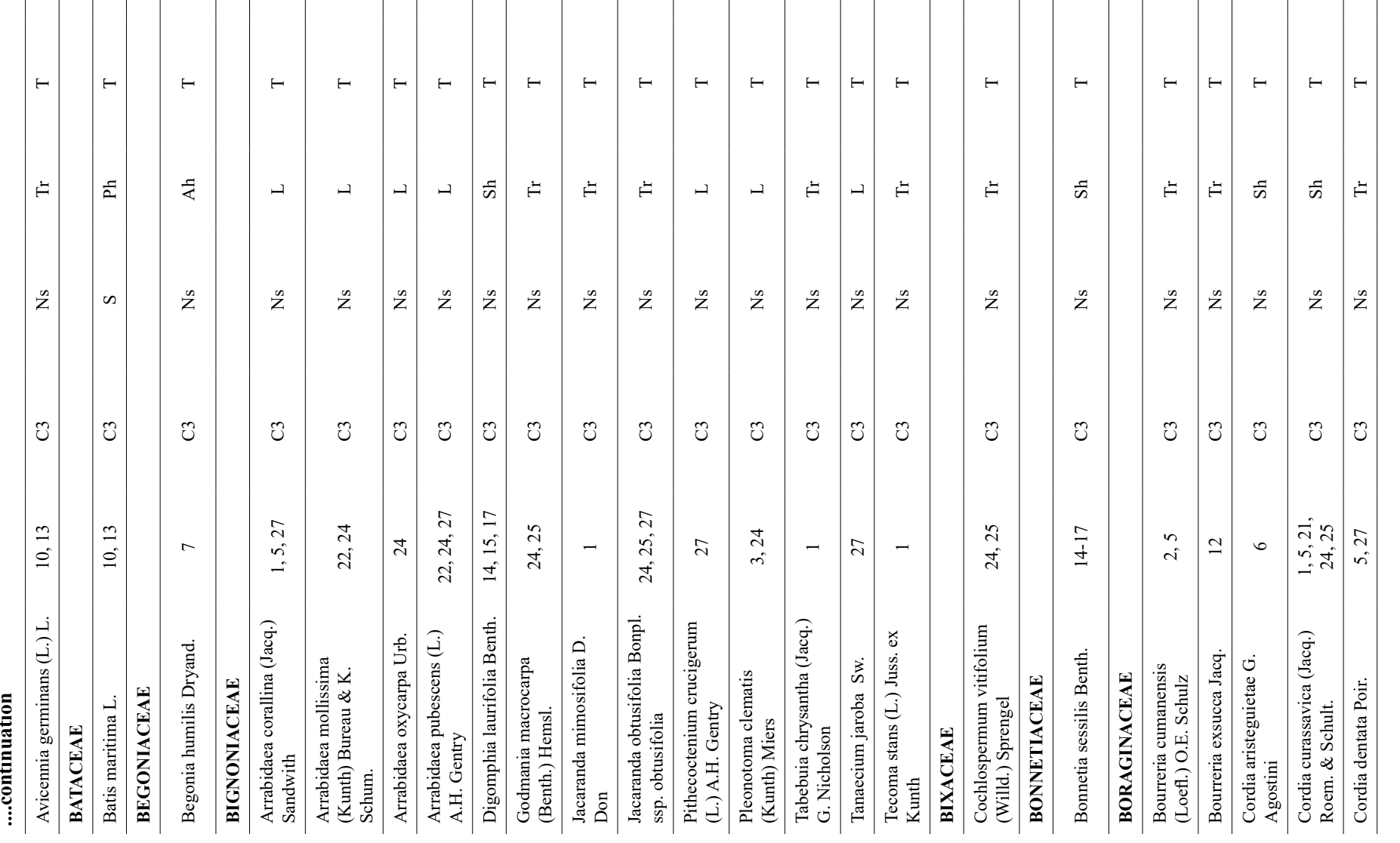


Ramírez, N. et al.

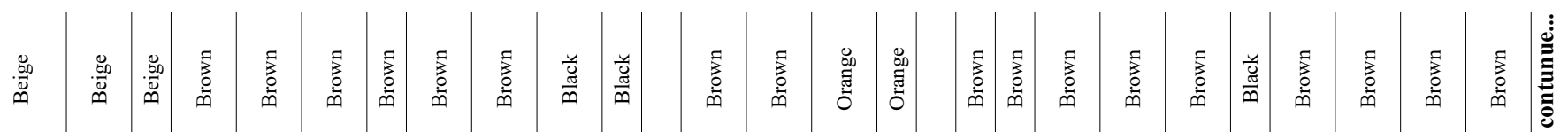

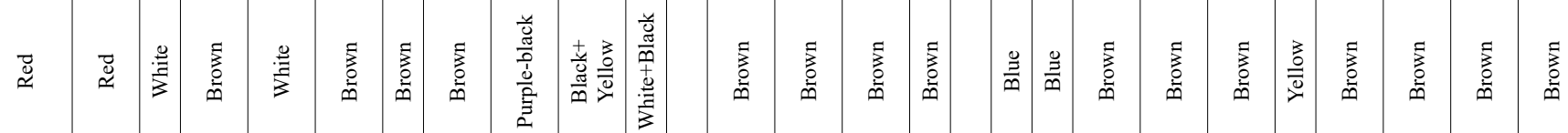

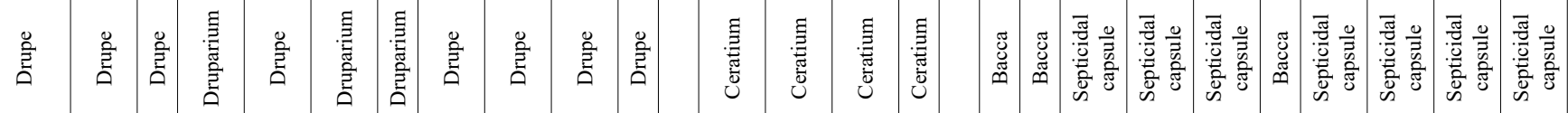

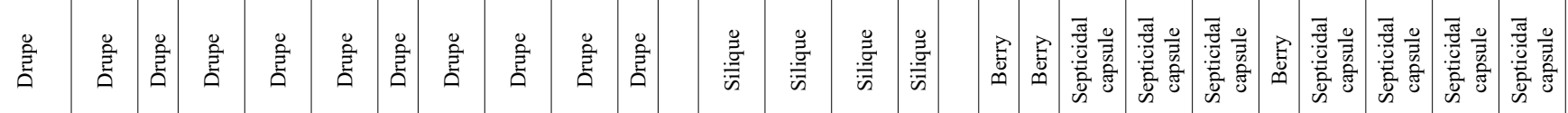

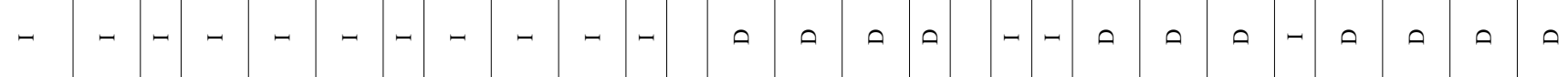

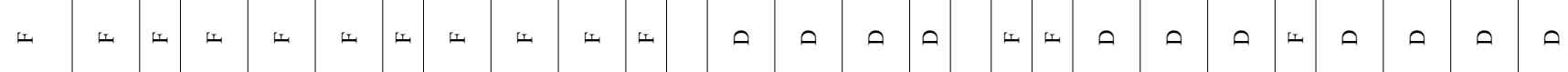

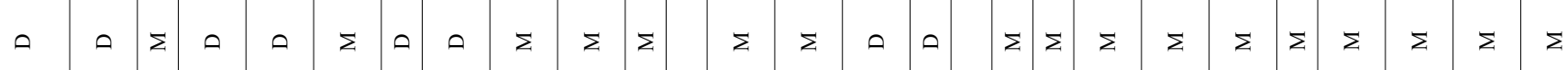

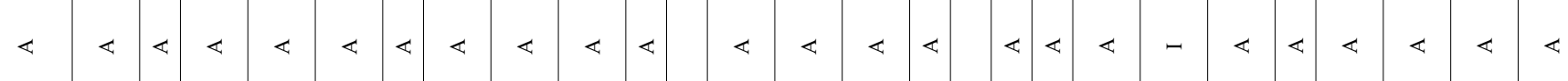

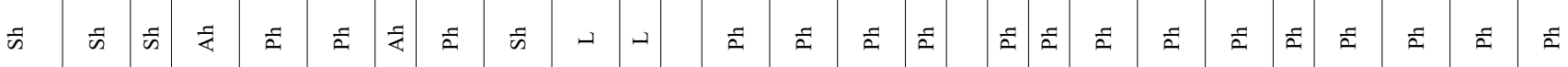

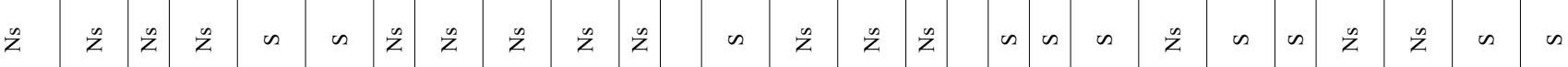

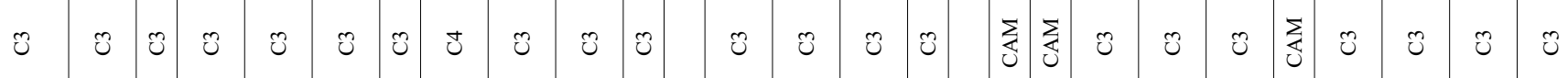

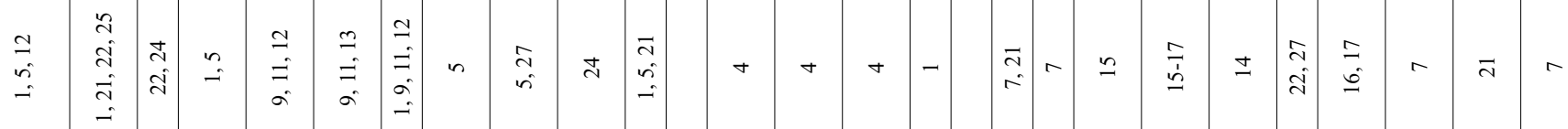

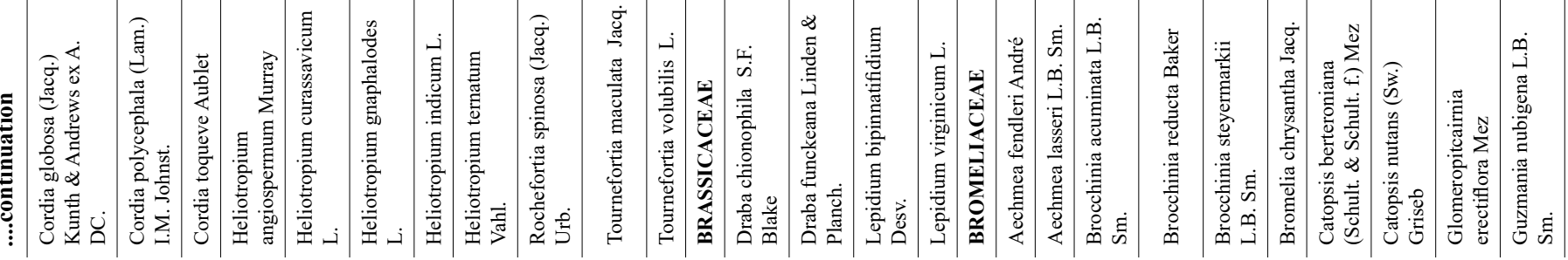




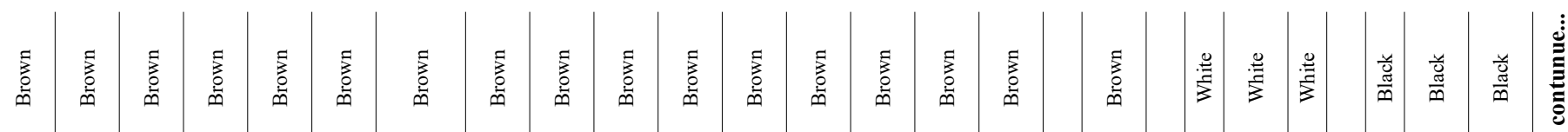

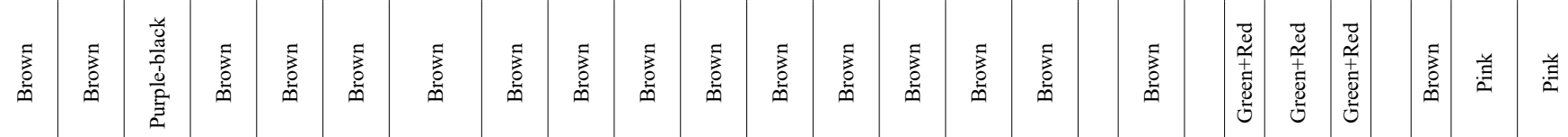

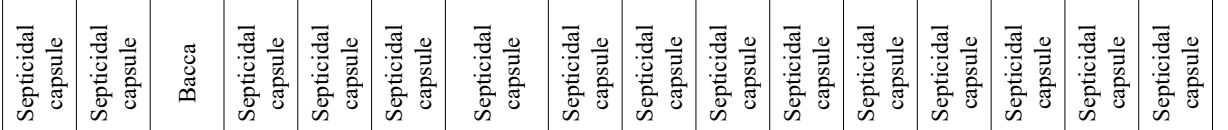

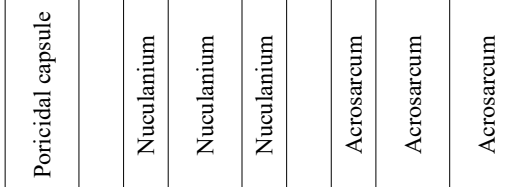

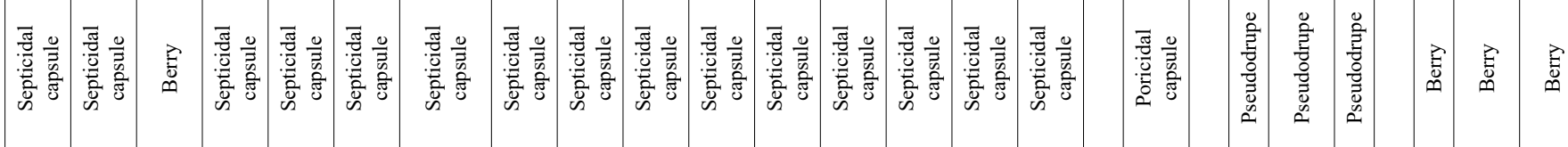
○ ○ 0 ш

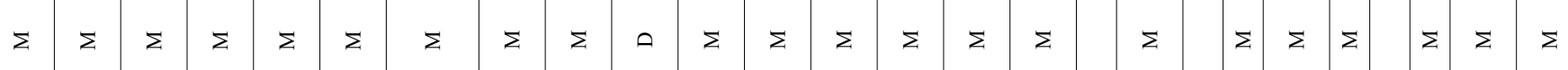

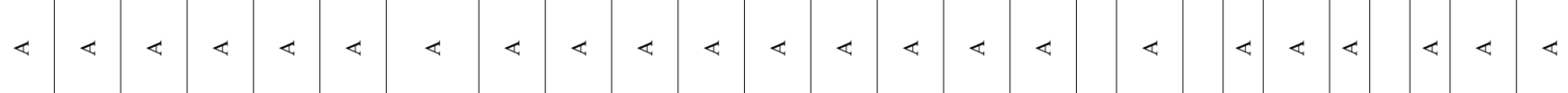

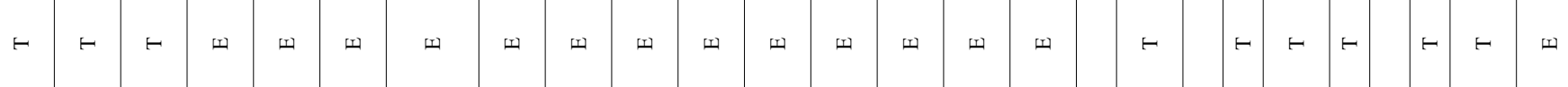

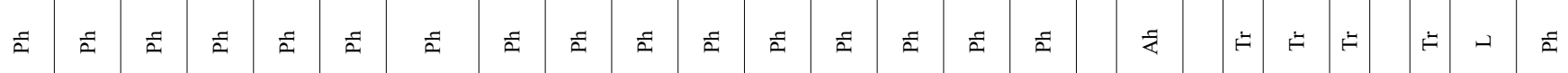

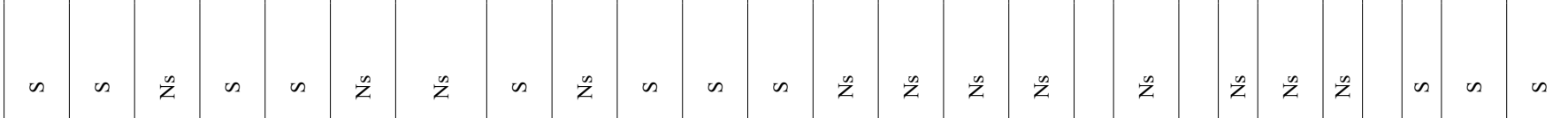

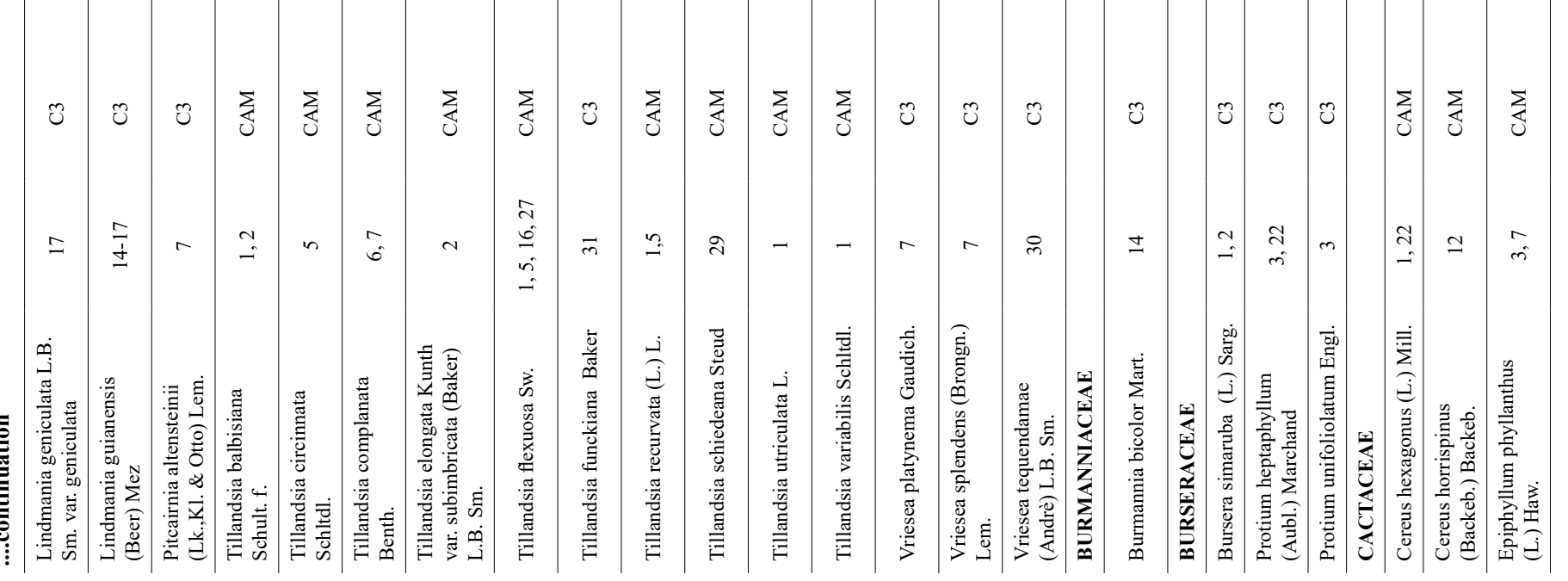


Ramírez, N. et al.

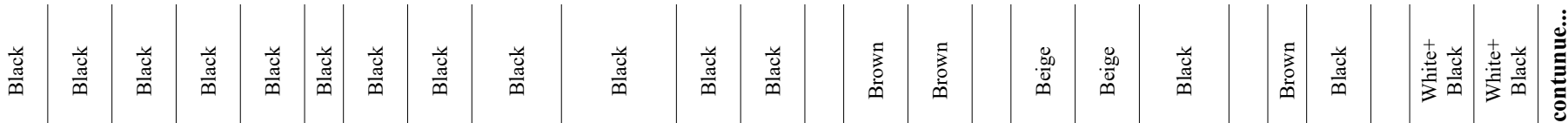

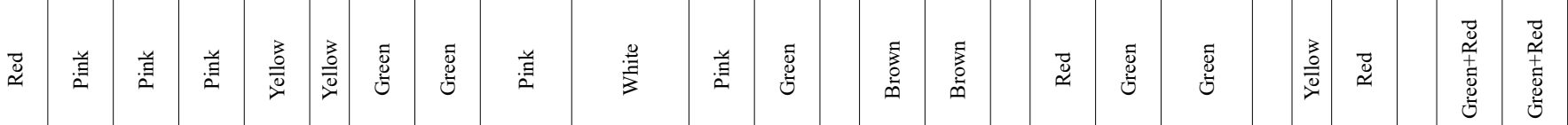

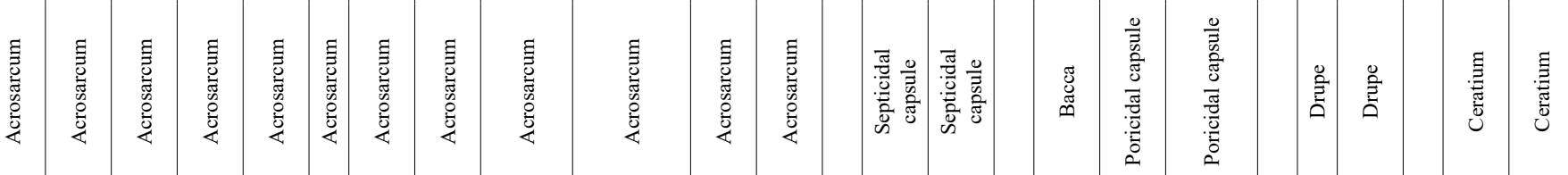

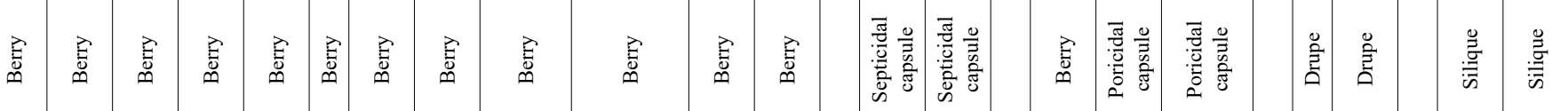

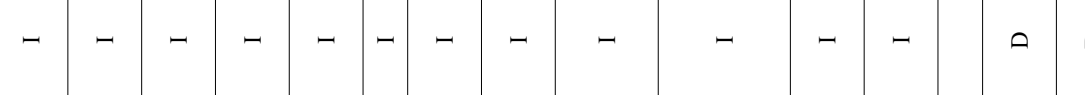

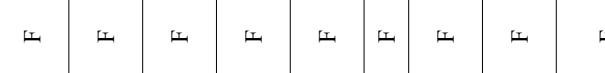

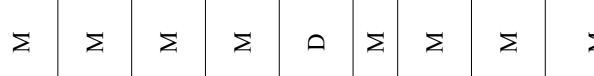

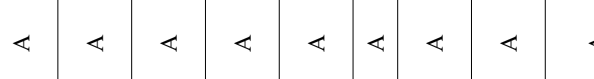

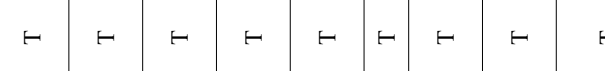

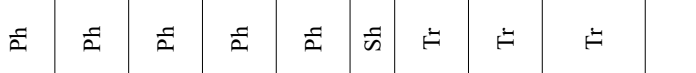

an as as as as as as as o

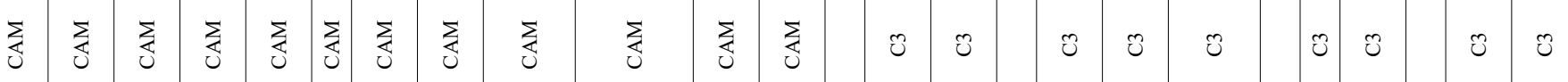

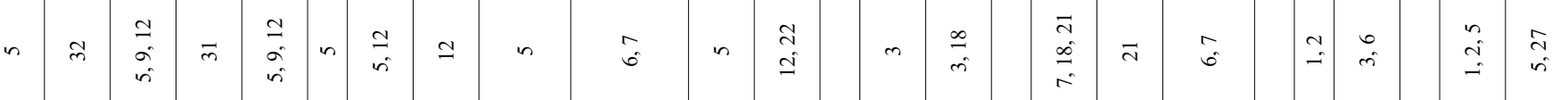

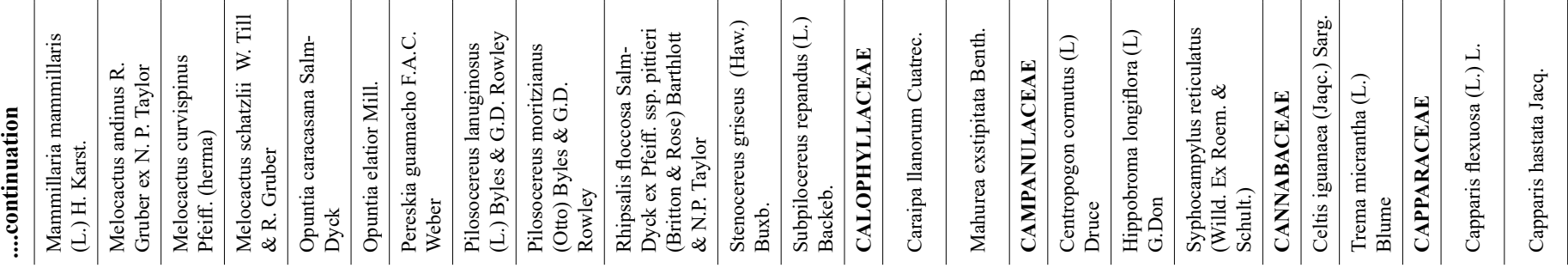




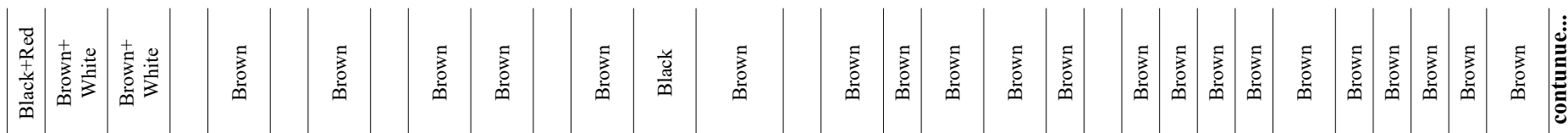

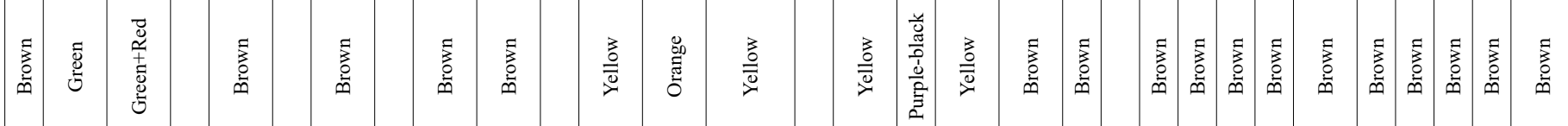

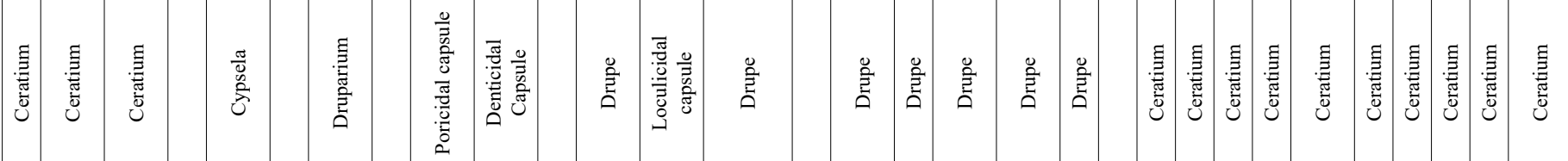

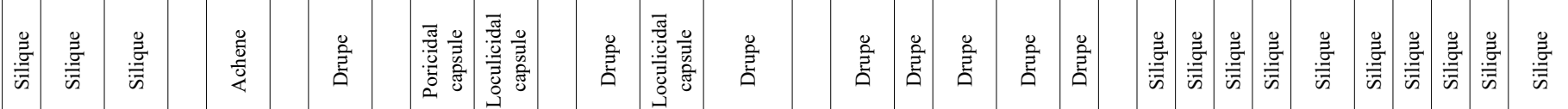
○ ○ В ш

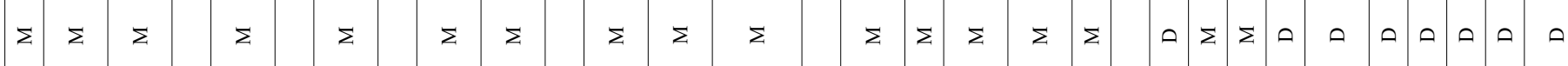

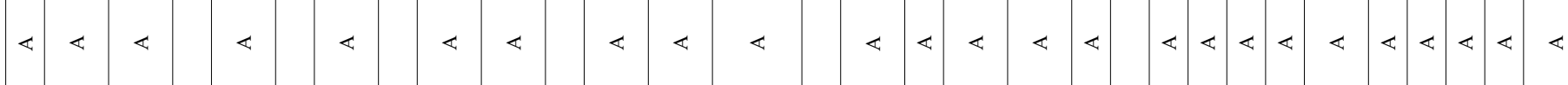

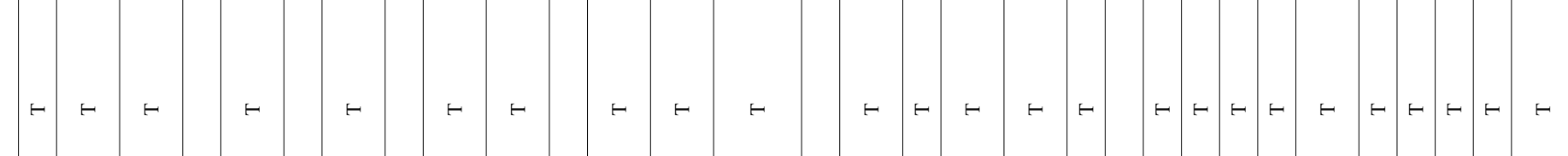

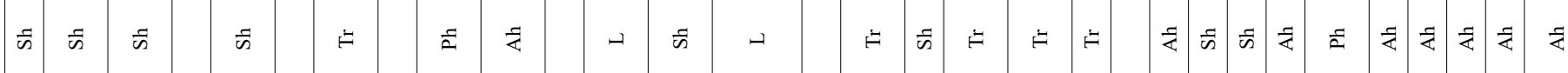

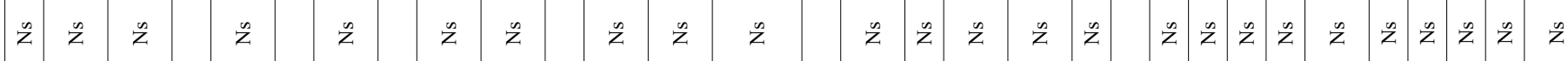

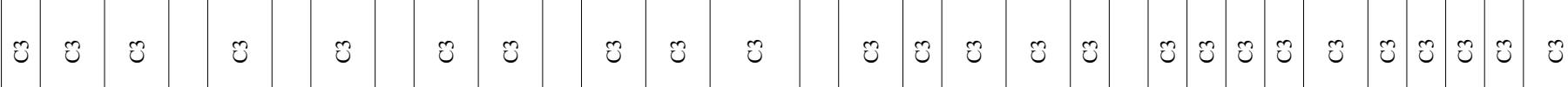

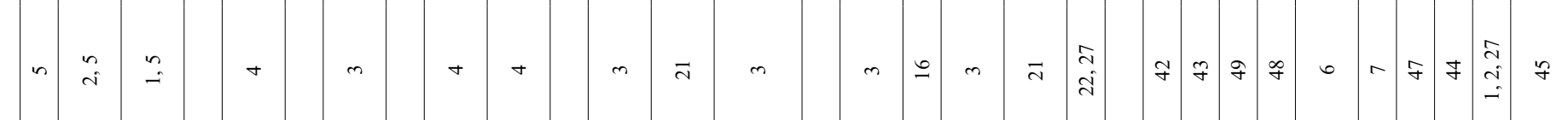

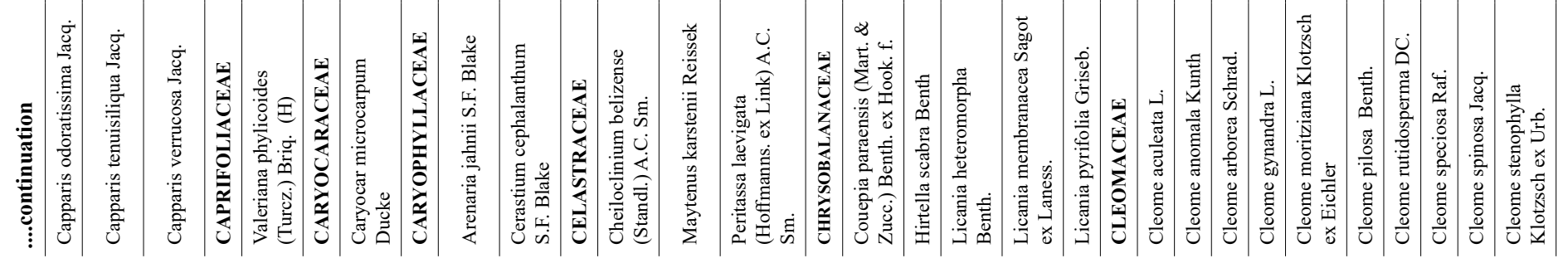


Ramírez, N. et al.

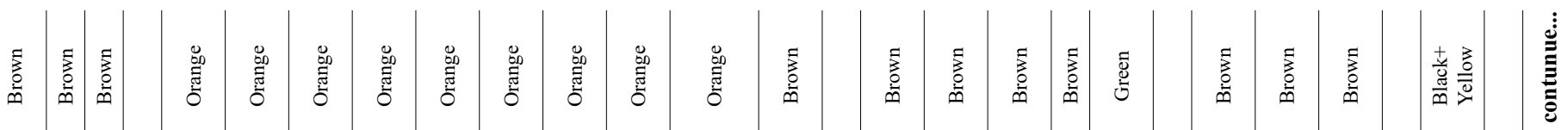

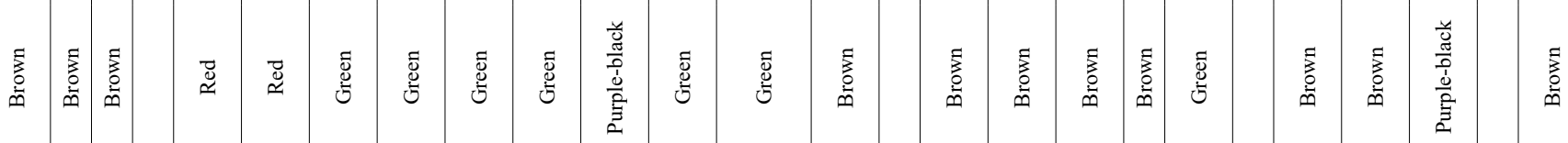

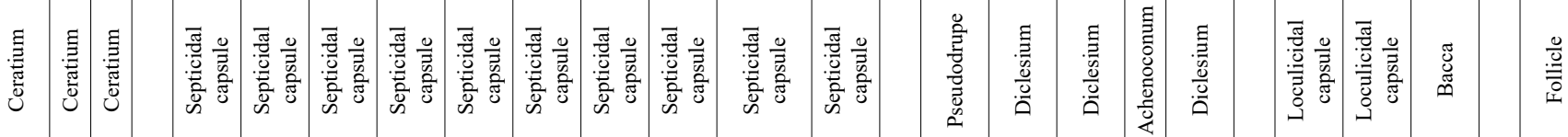

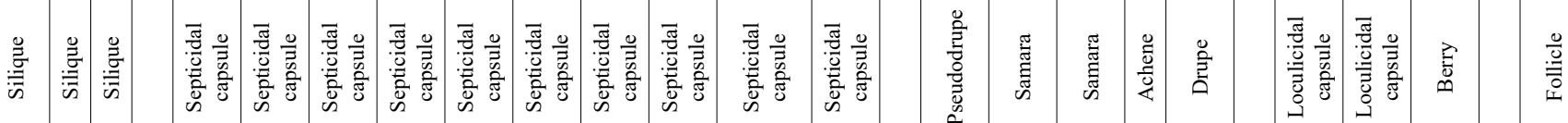

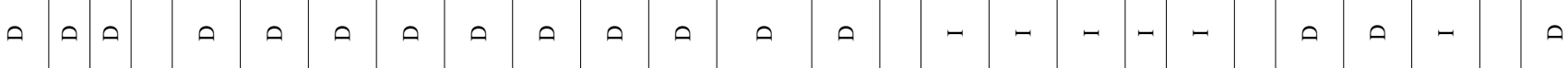

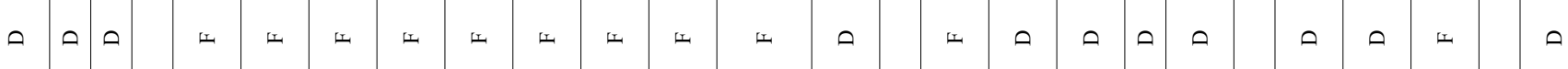

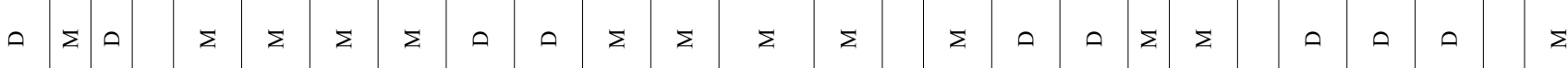

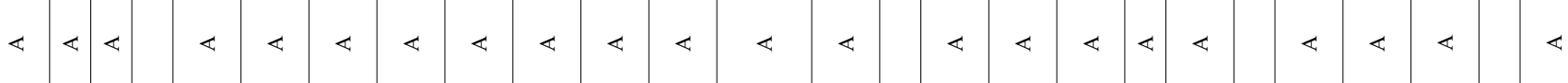

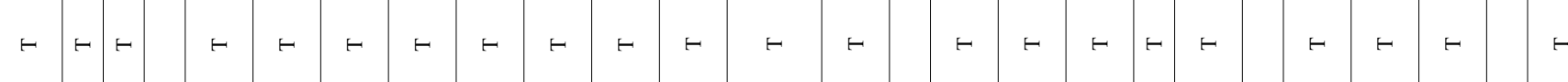

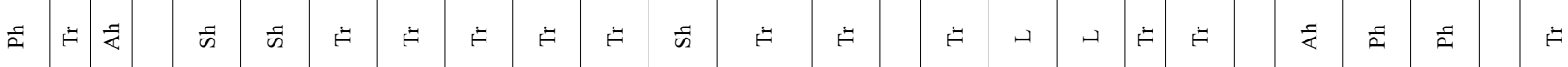

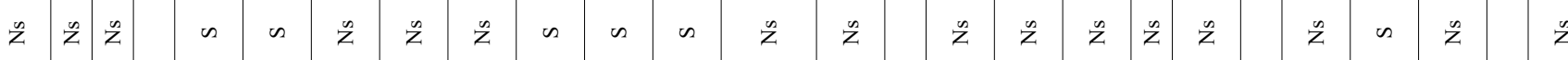

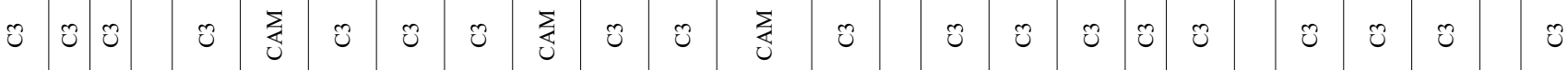

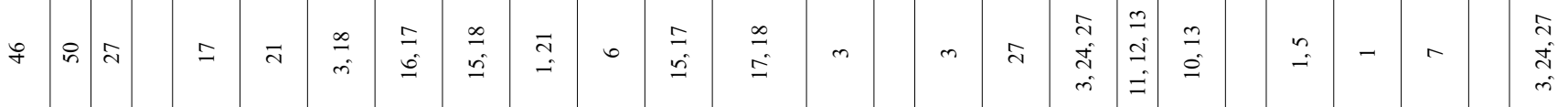

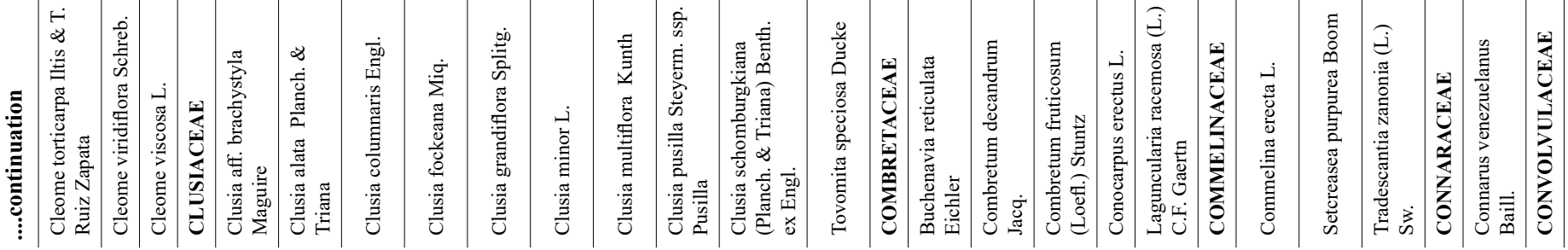




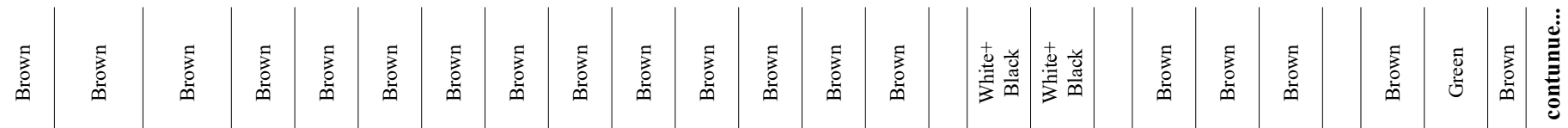

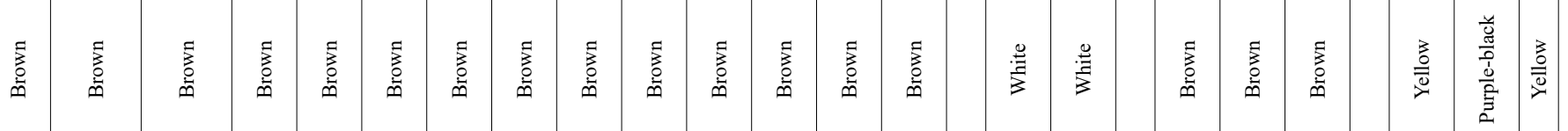

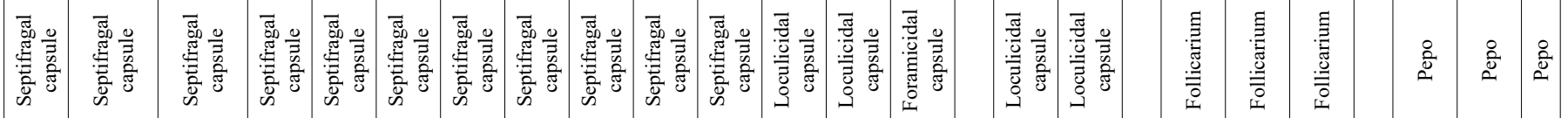

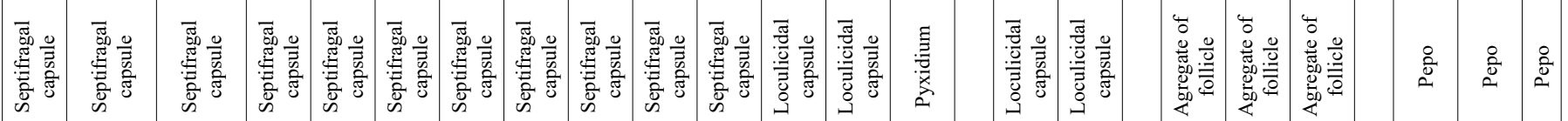
○ $ค$ ○ ○ $\quad$ ค

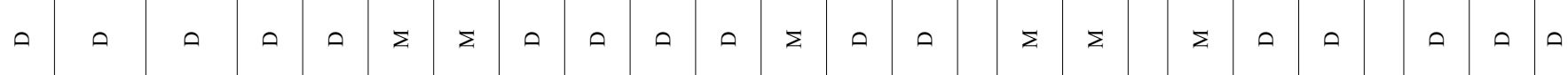

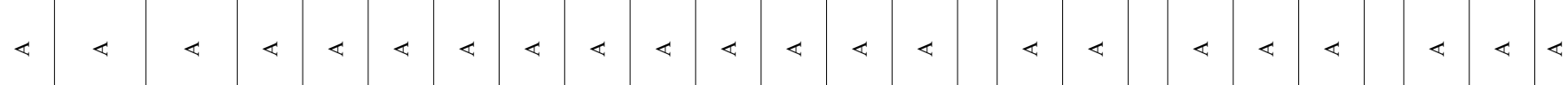

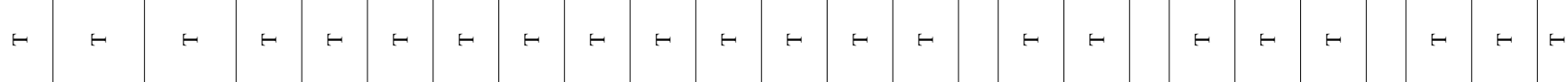
\lrcorner Е

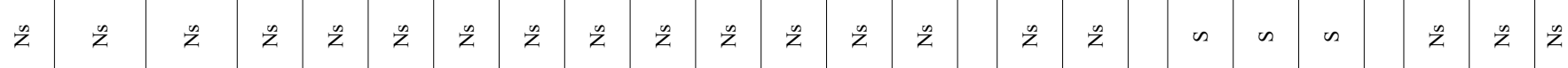

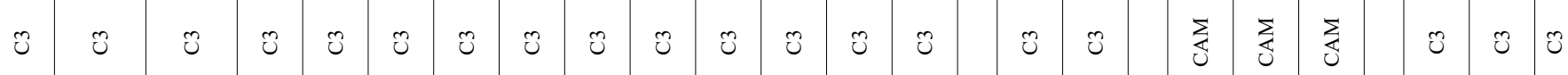

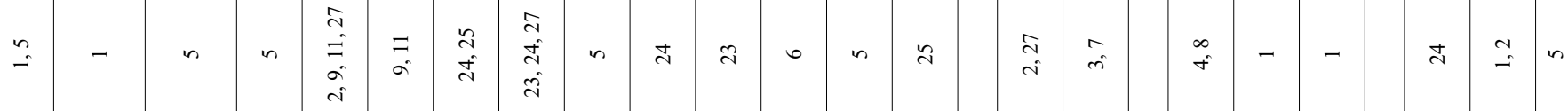

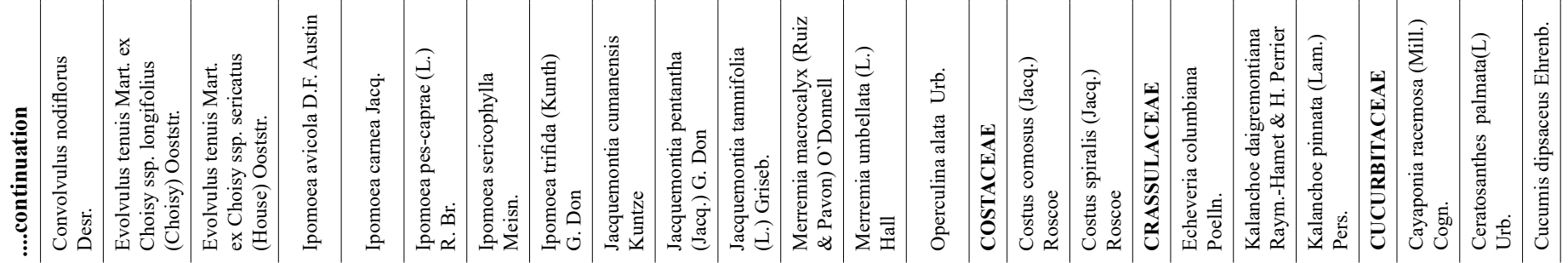


Ramírez, N. et al.

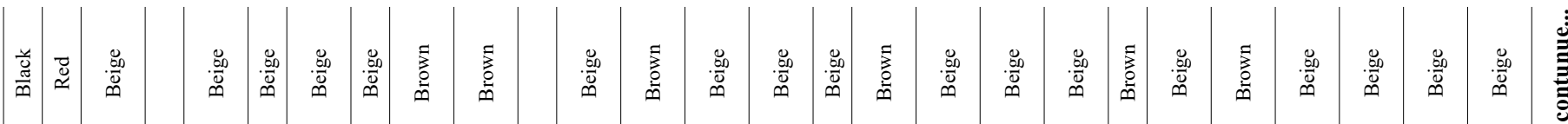

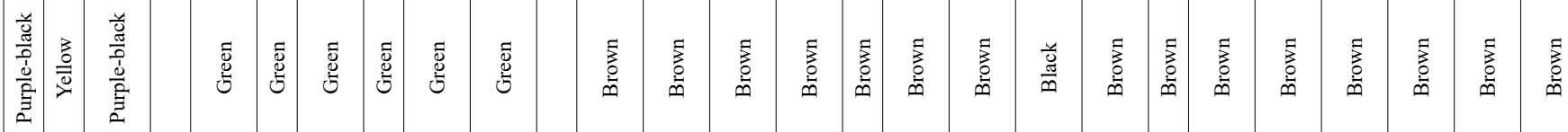

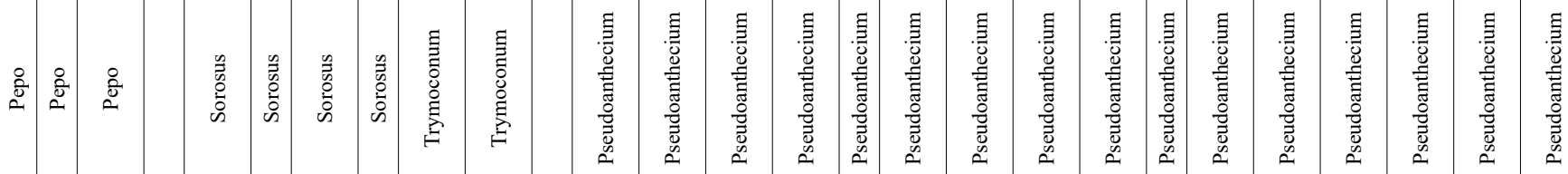

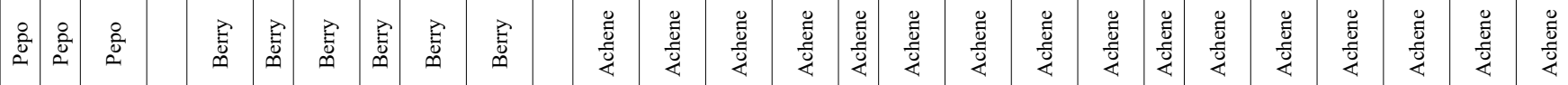
$-\infty-$

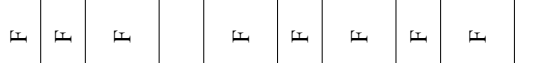

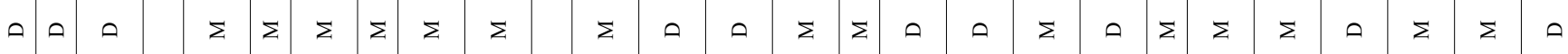

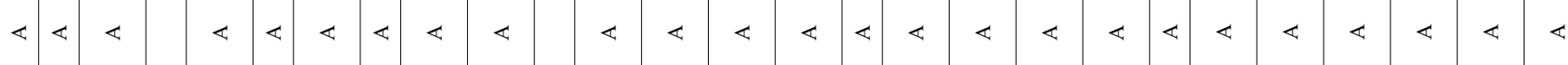

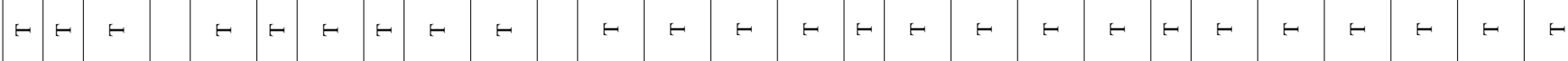

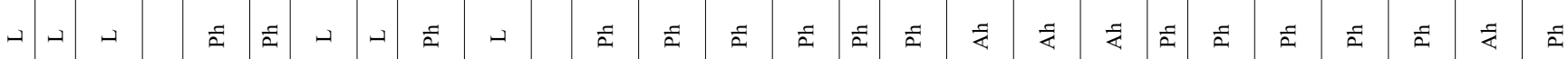

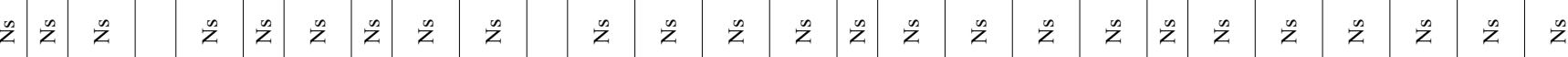

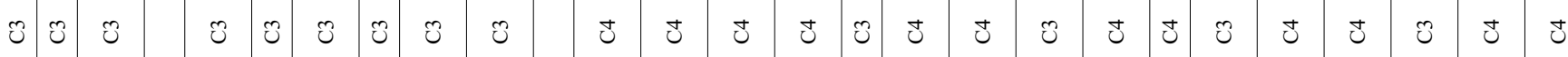

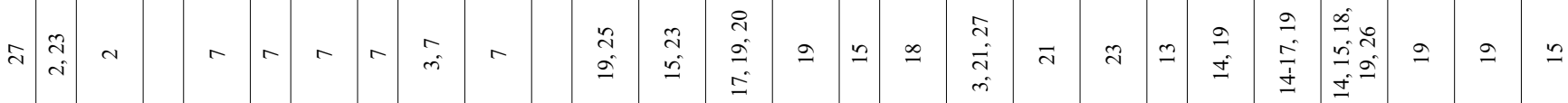

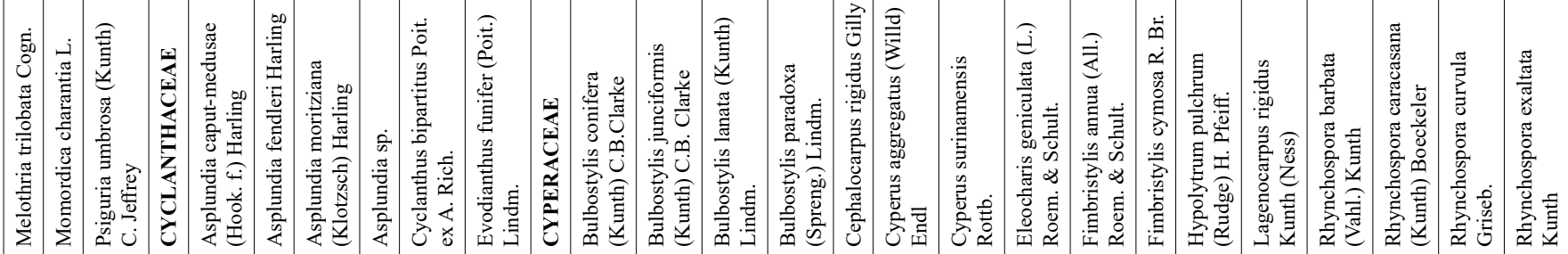




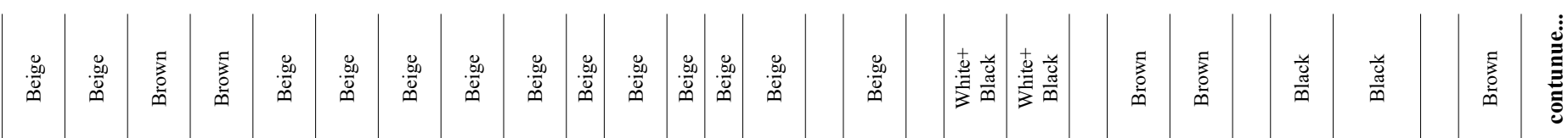

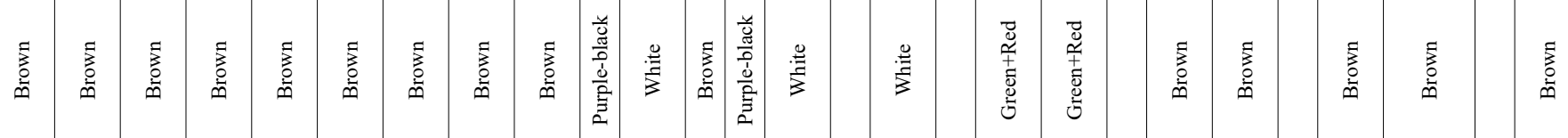

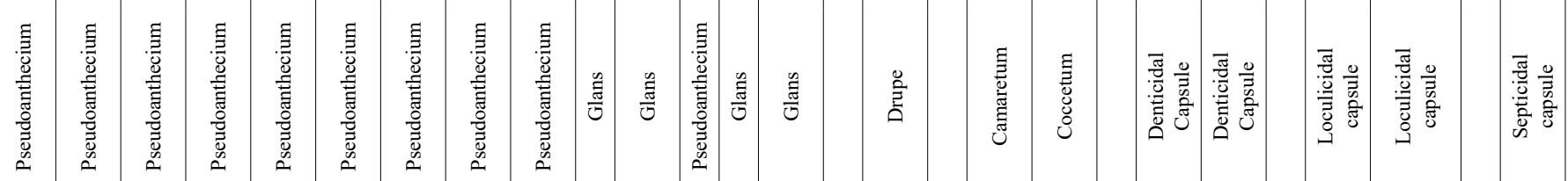

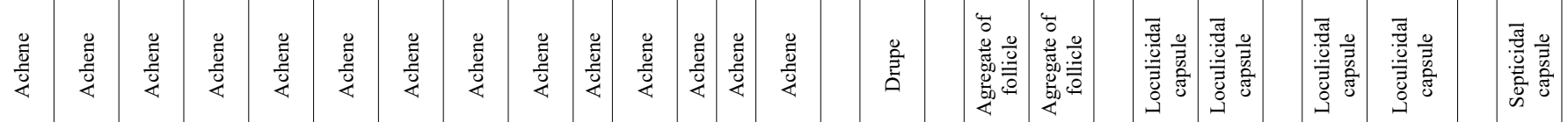

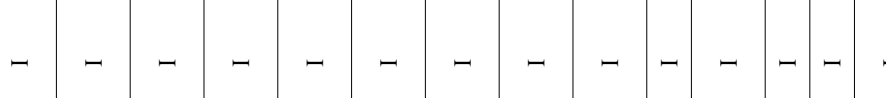

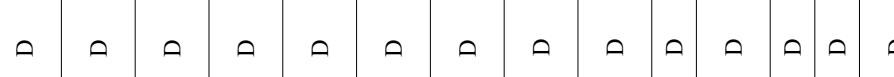

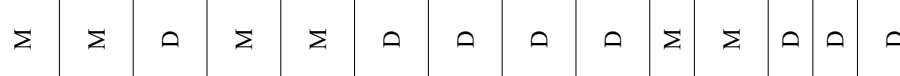

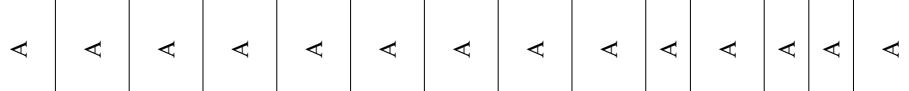

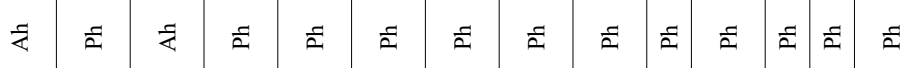

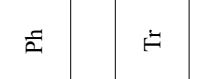

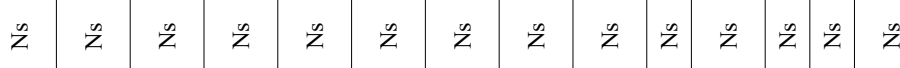

\begin{tabular}{l|l|l|l|l}
$n$ & $n$ & $n$ & $z$ & $z$
\end{tabular}

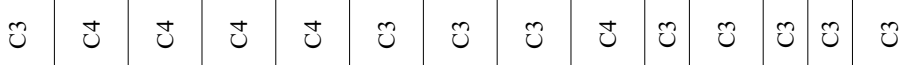

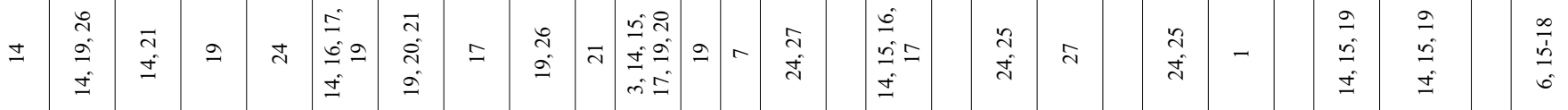

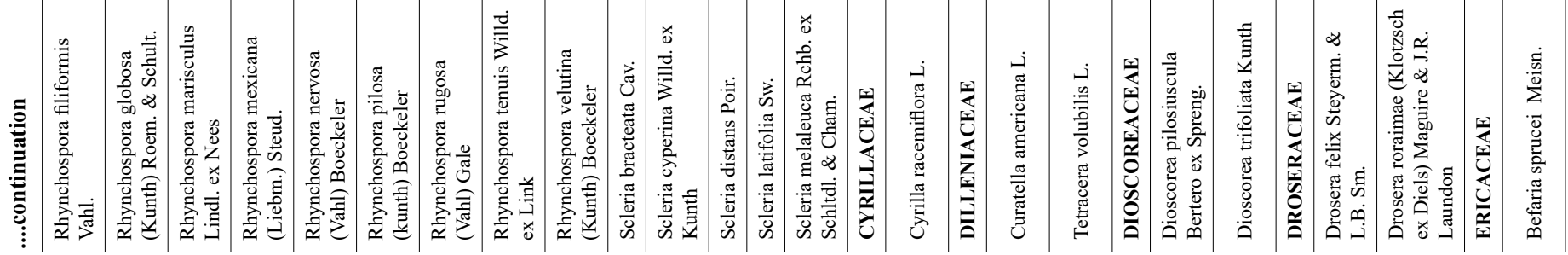


Ramírez, N. et al.

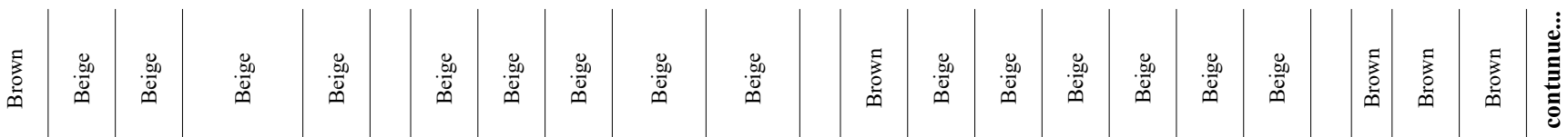

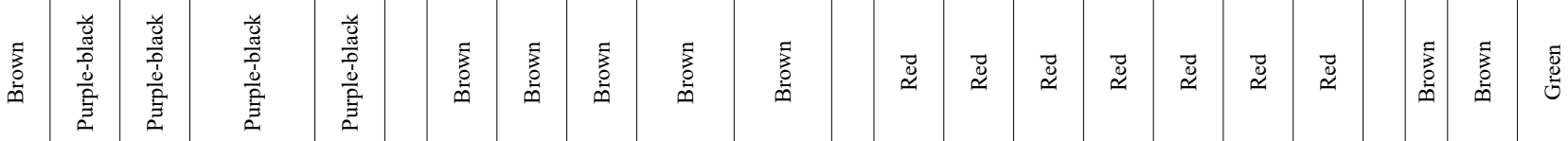

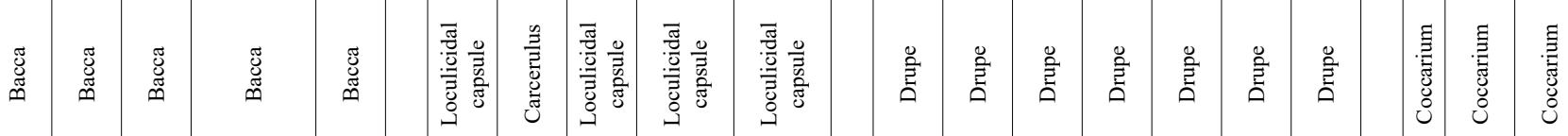

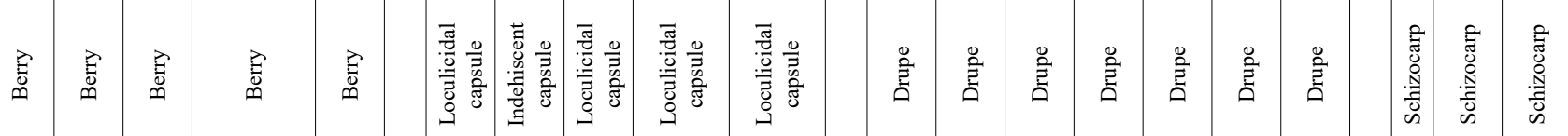

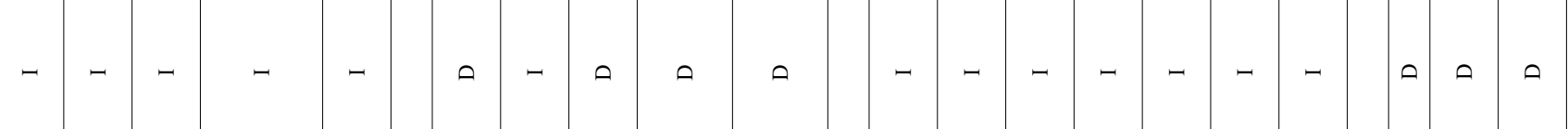
ш ш ш ш ш

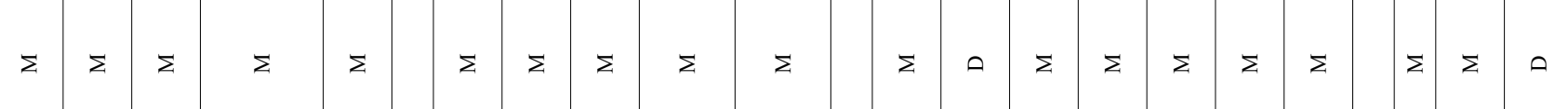

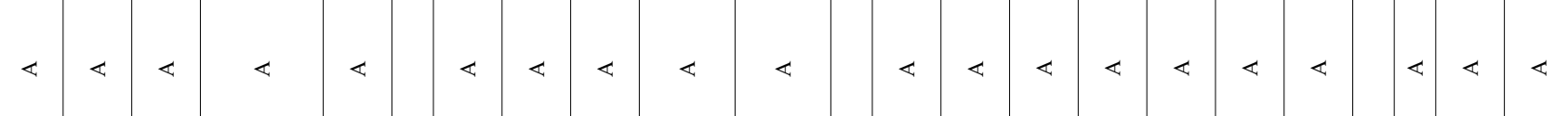
क

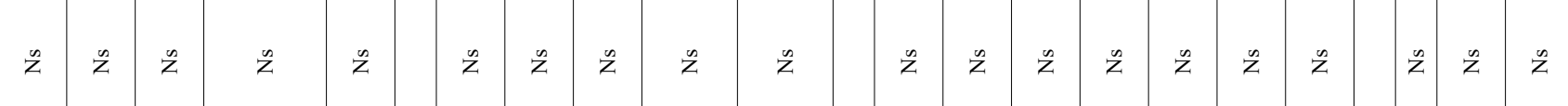

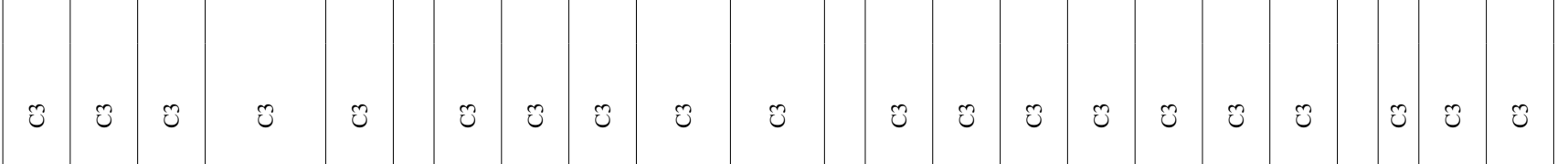

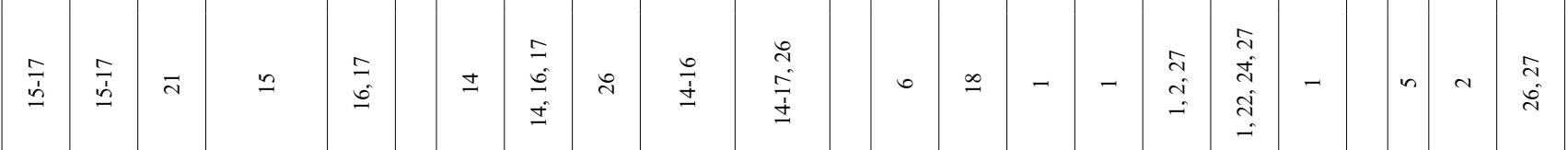

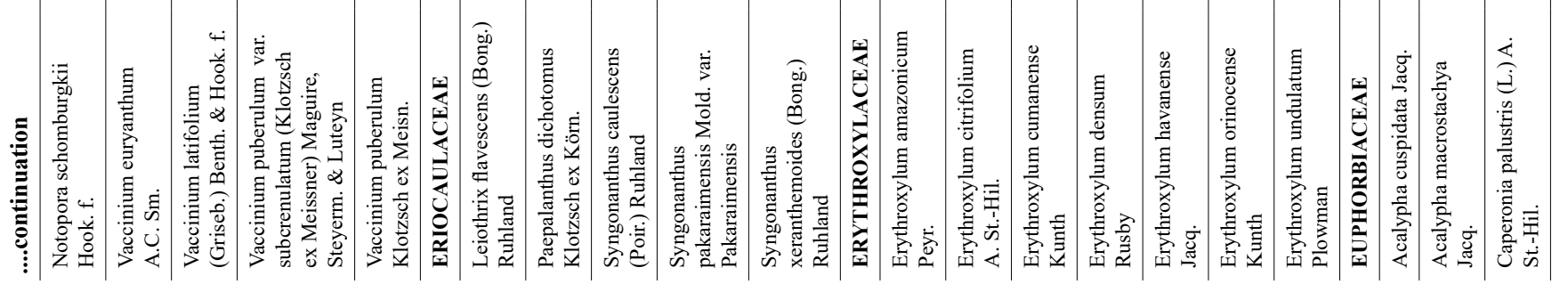




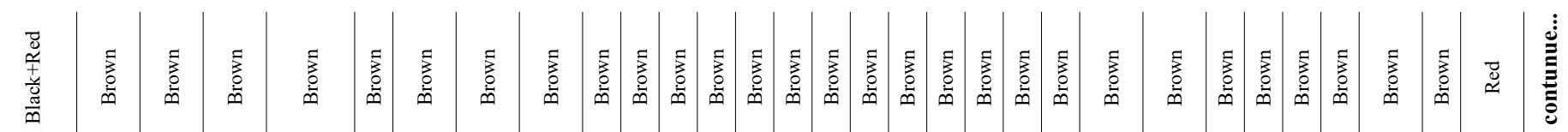

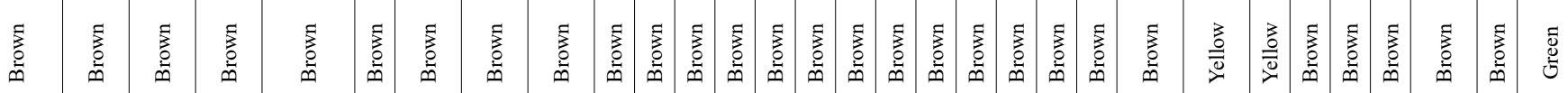

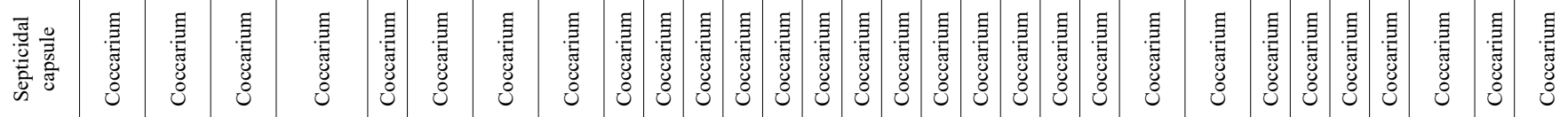

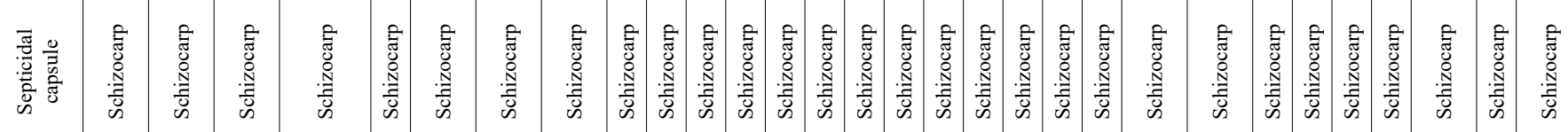

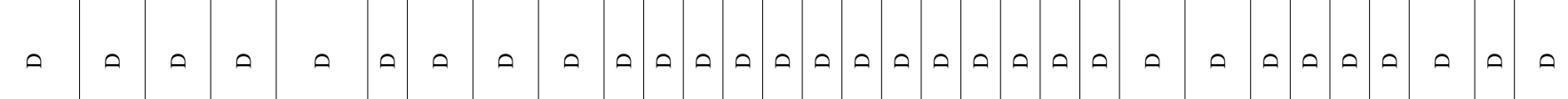

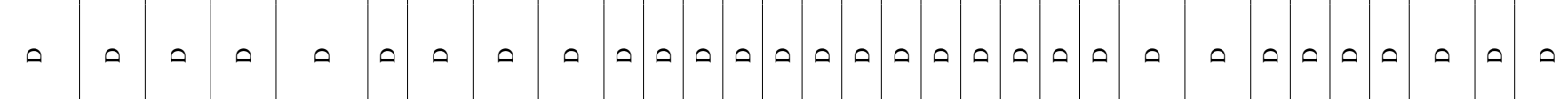

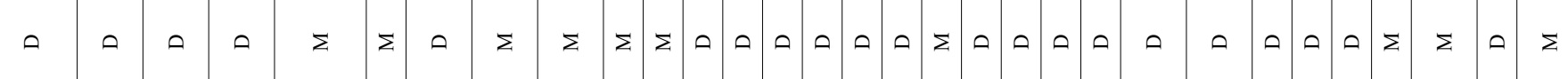

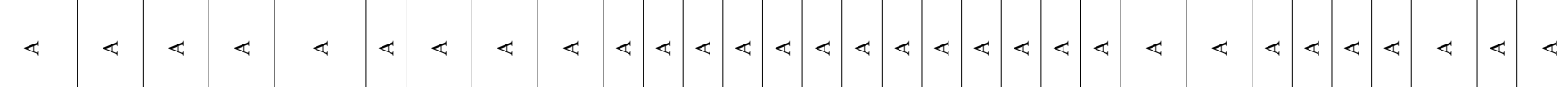

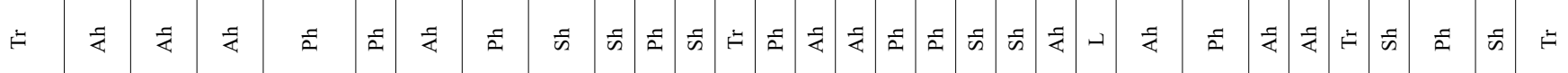

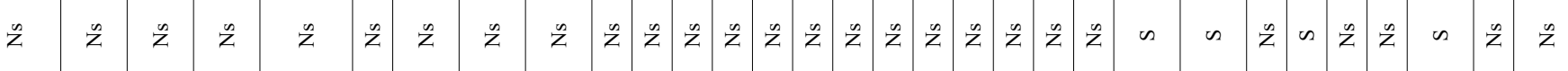

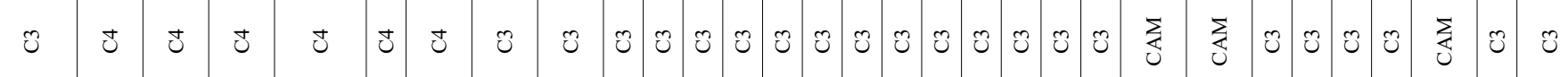

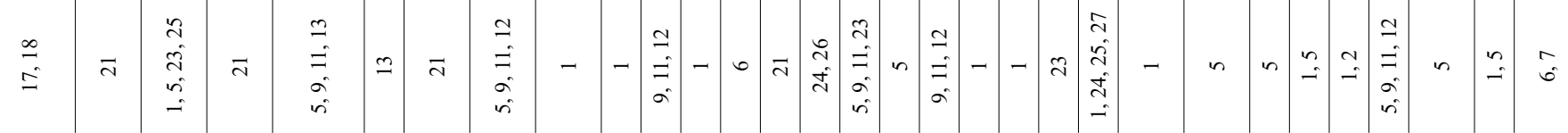

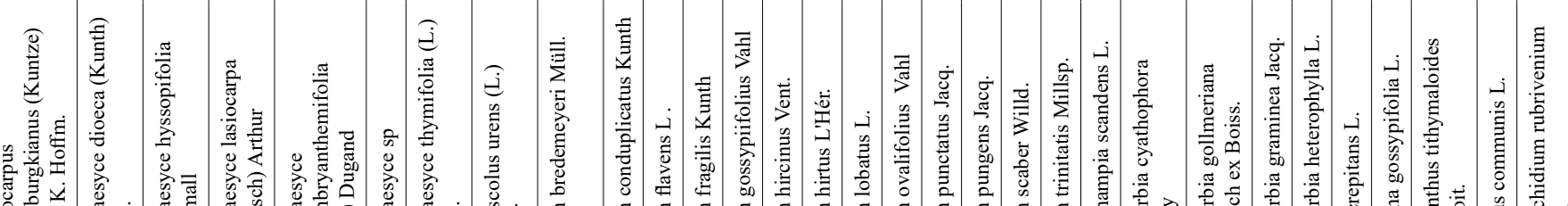

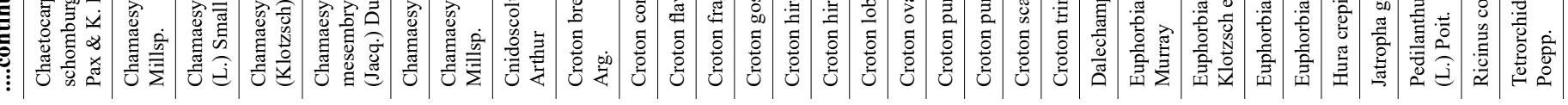


Ramírez, N. et al.

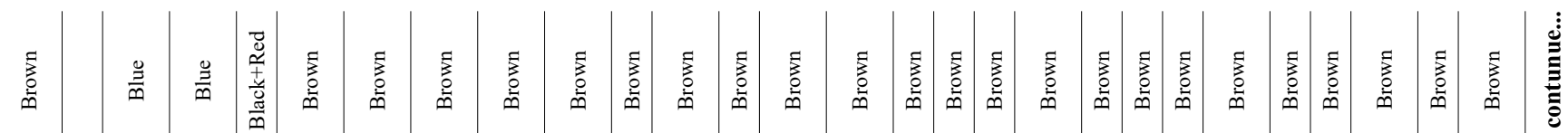

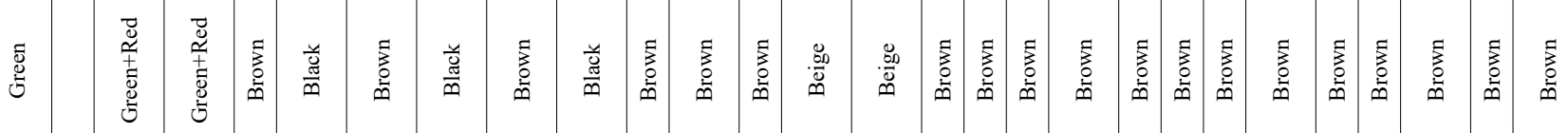

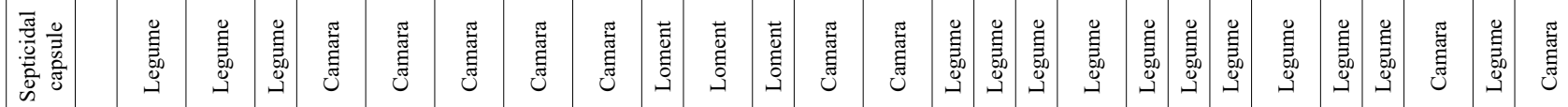

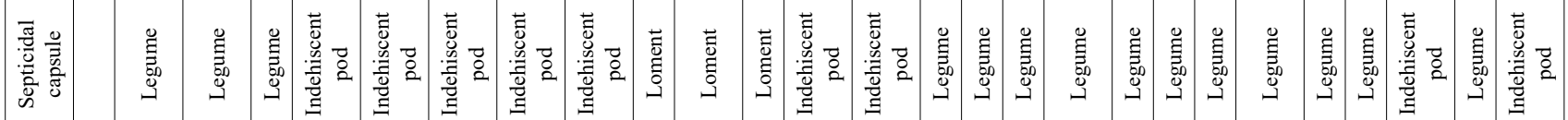

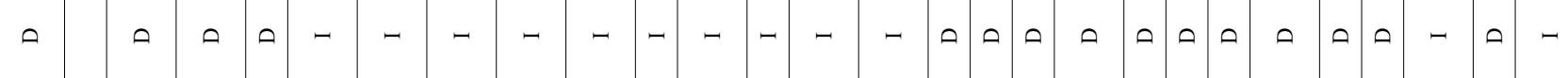

- $\quad$ ○

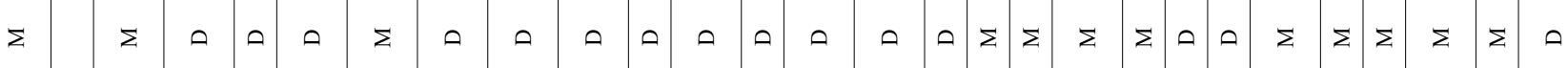

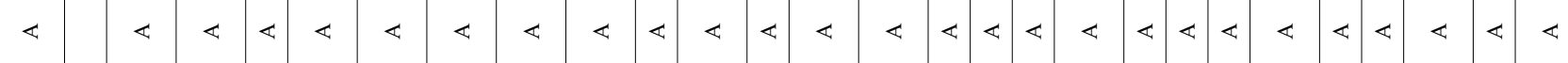

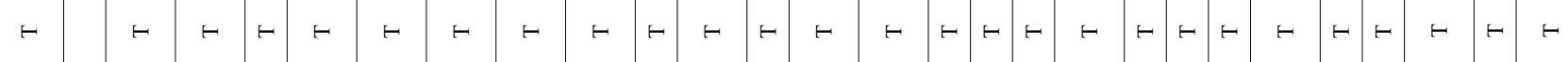

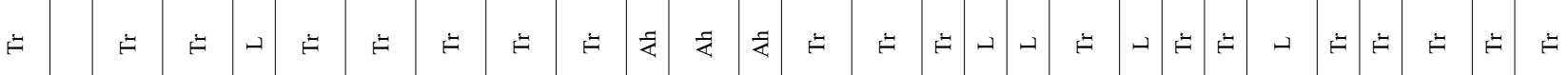

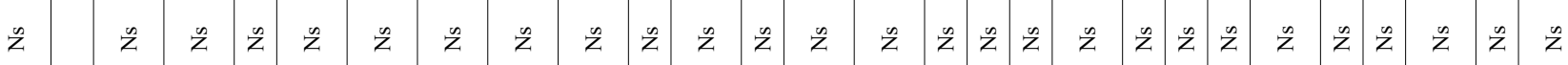

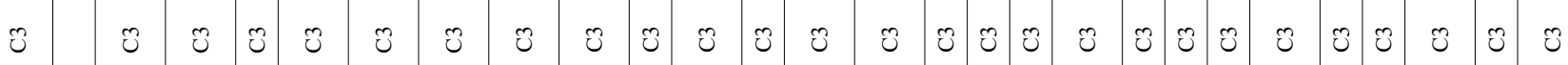

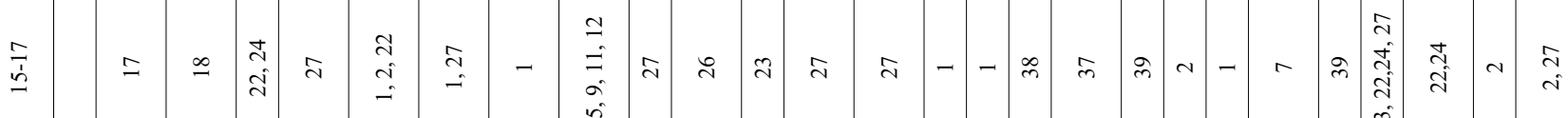

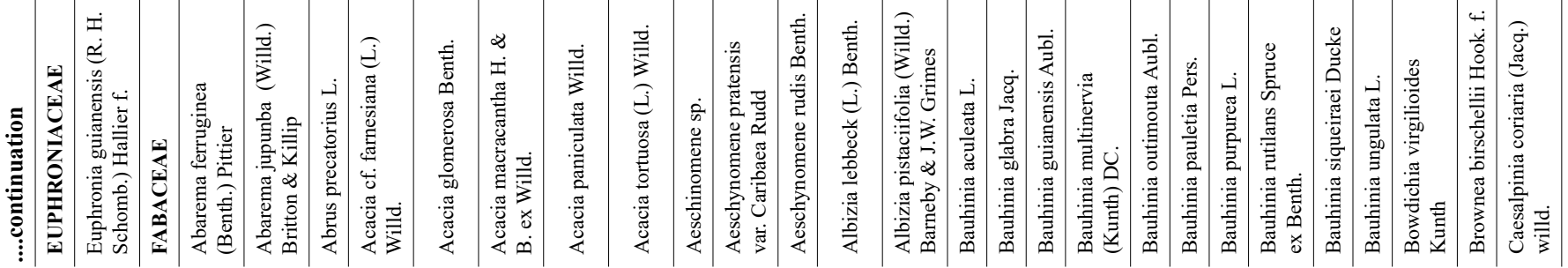




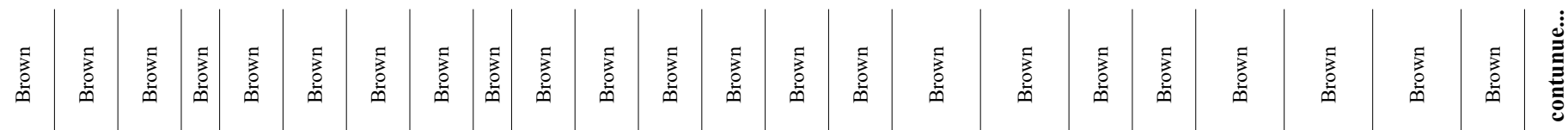

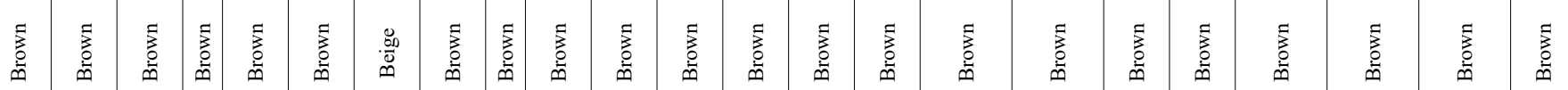

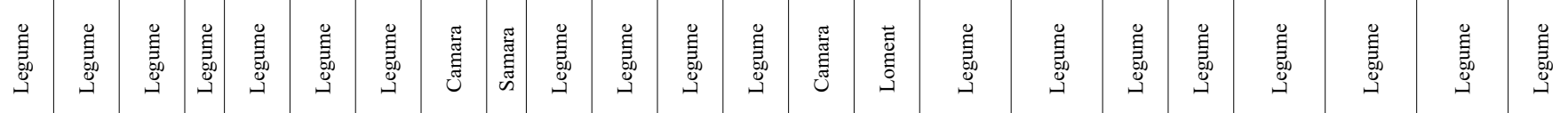

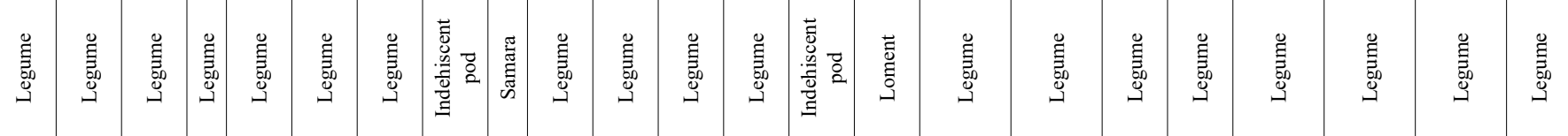
○ $ค$ ค

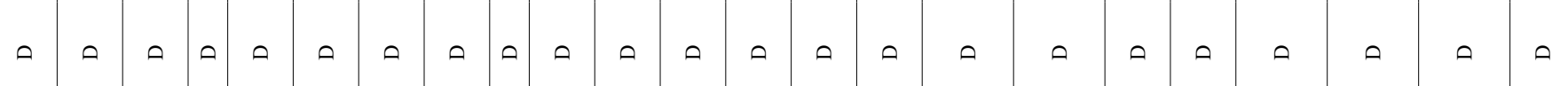

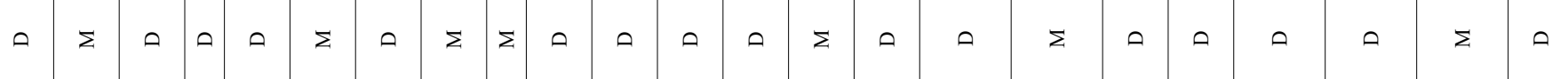

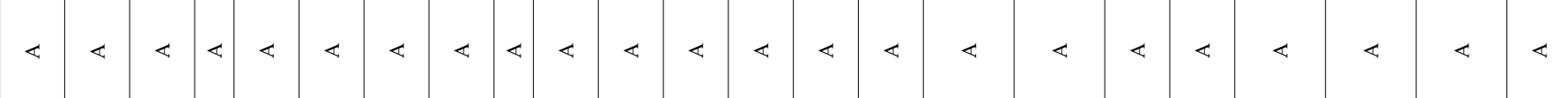

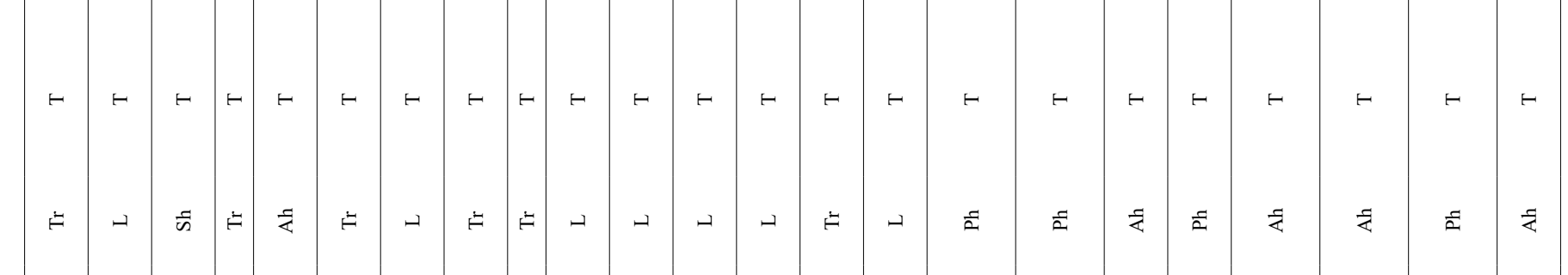

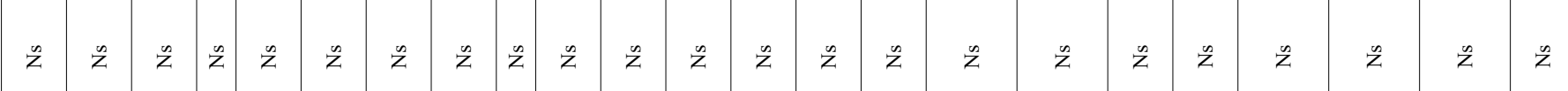

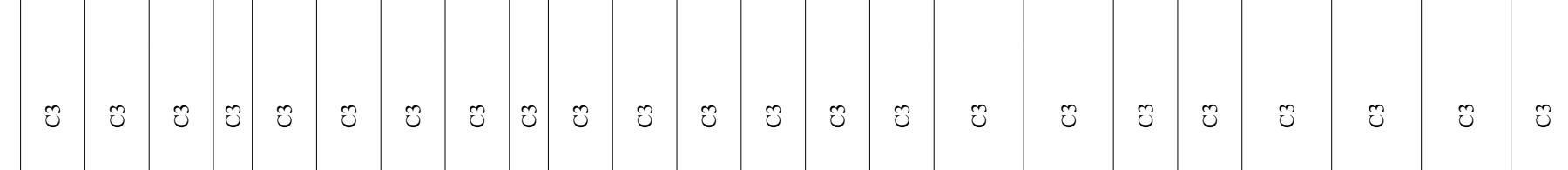

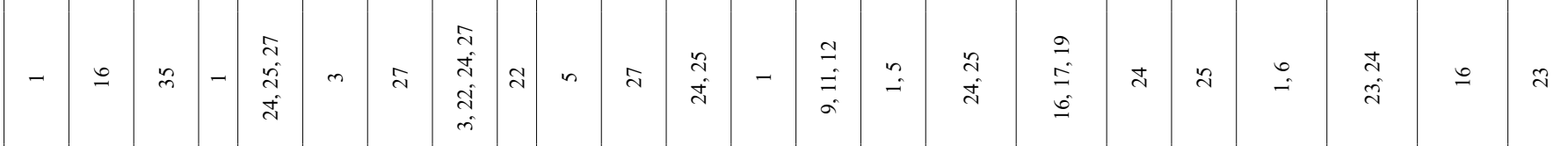

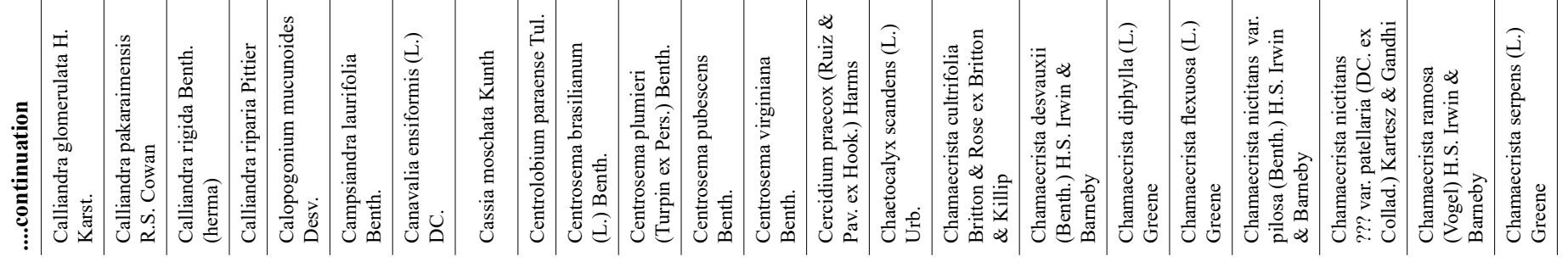


Ramírez, N. et al.

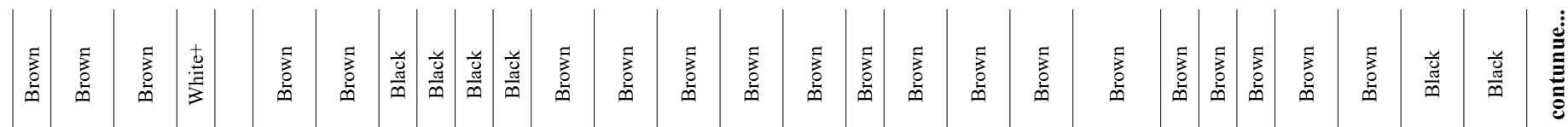

晜俉

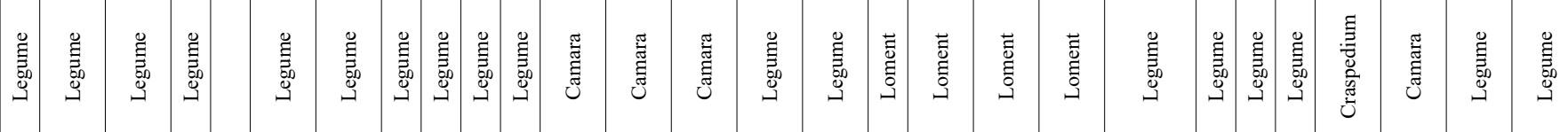

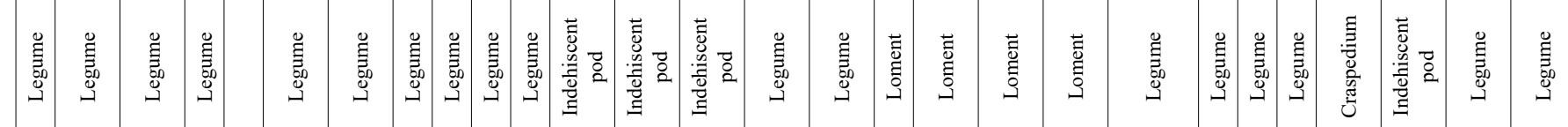

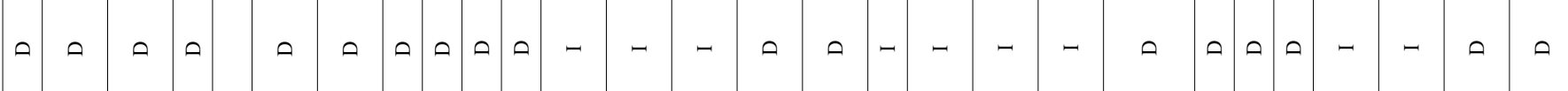
○

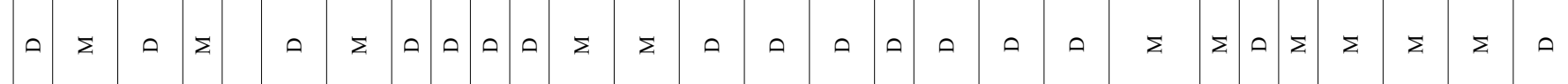

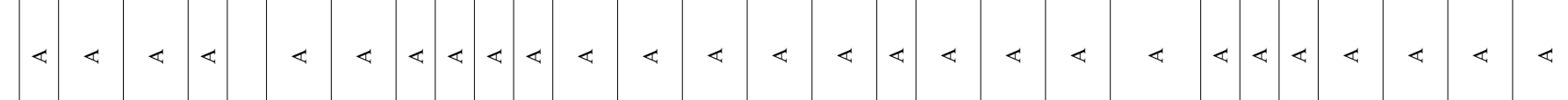

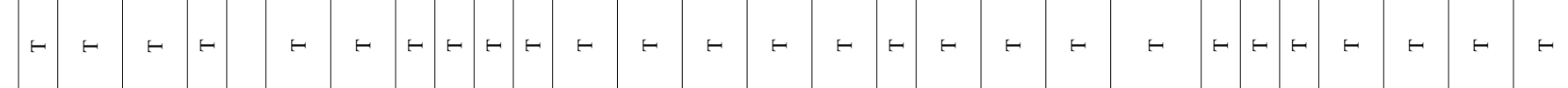

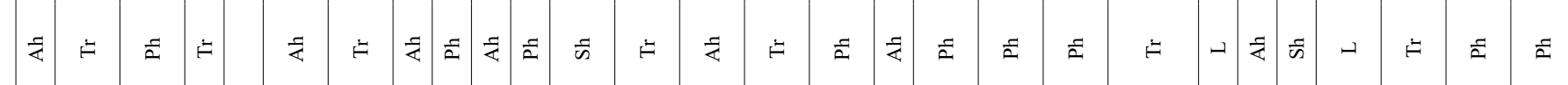

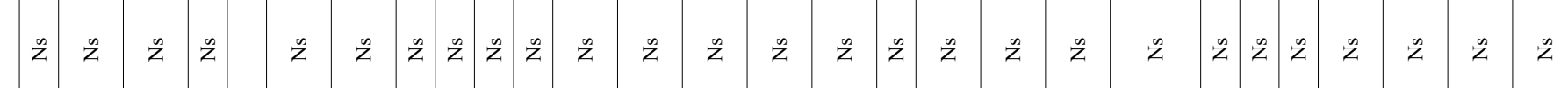

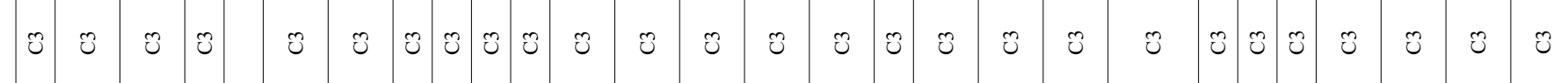

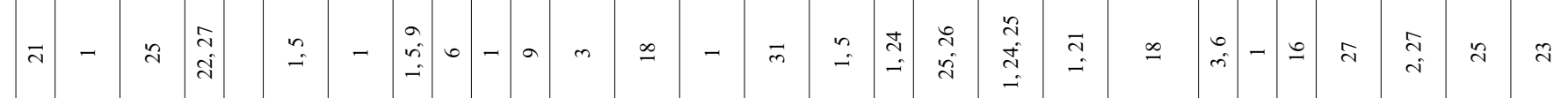

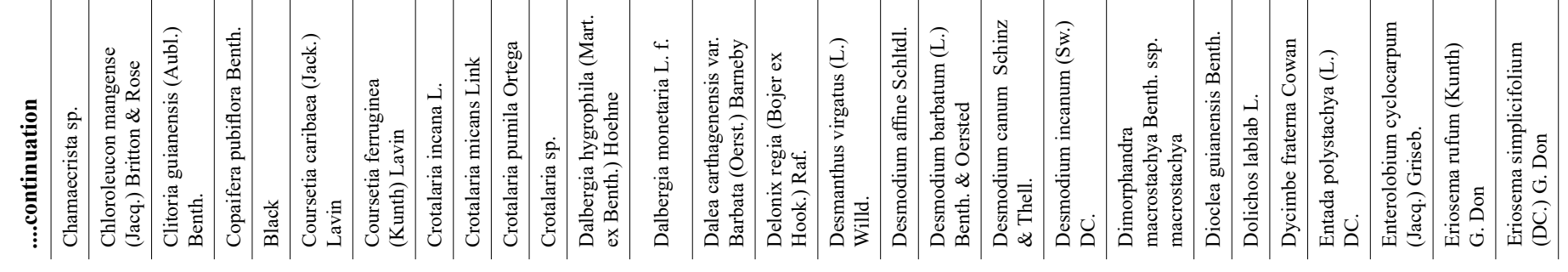




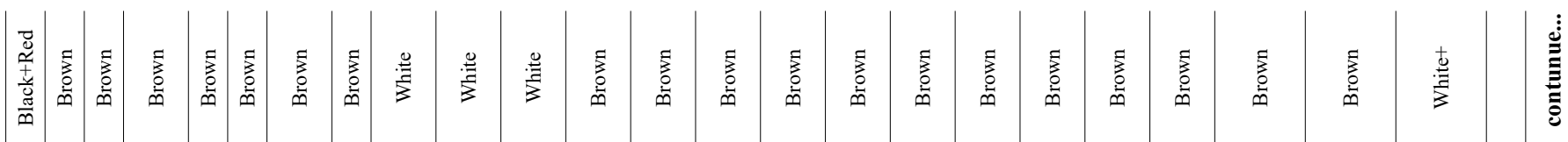

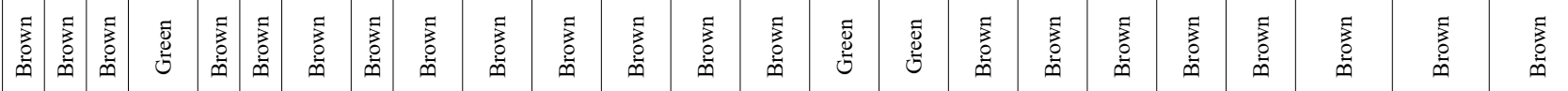

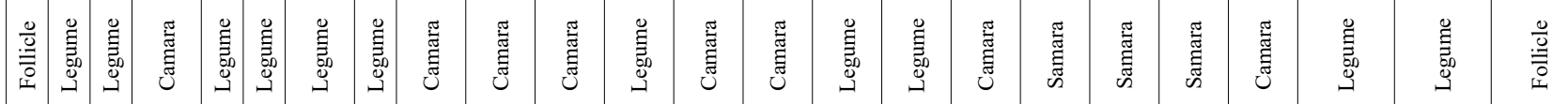

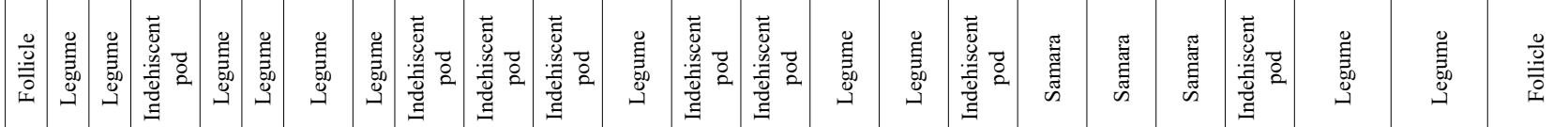

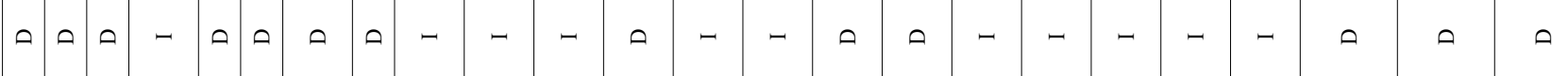

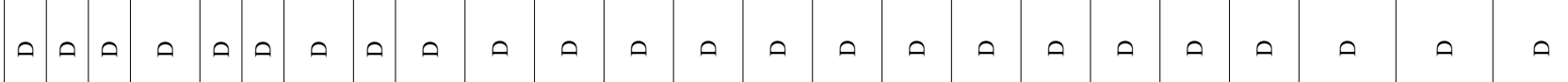

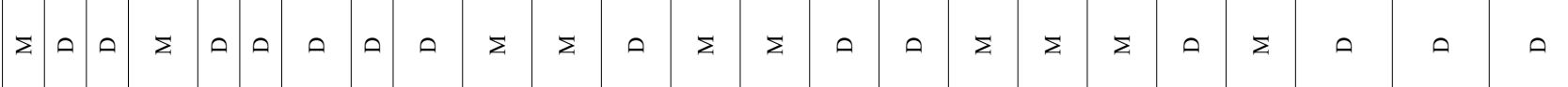

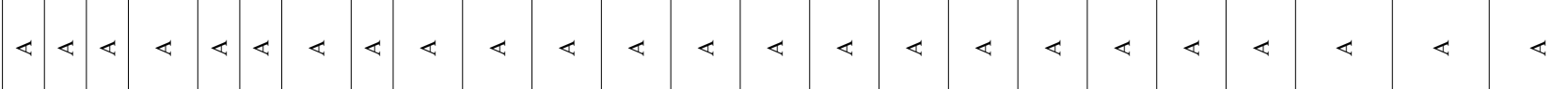

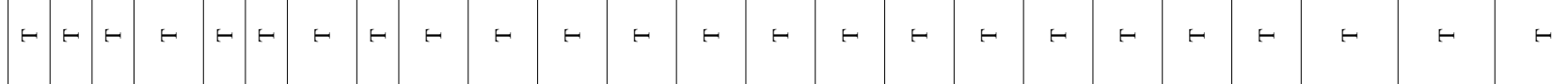

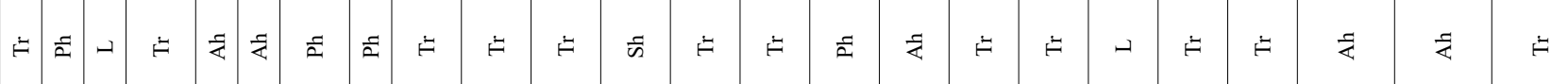

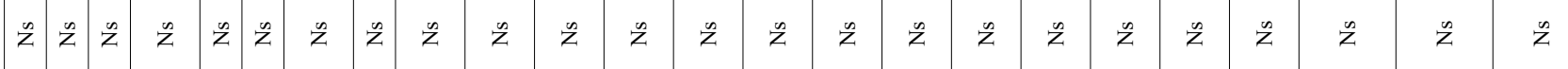

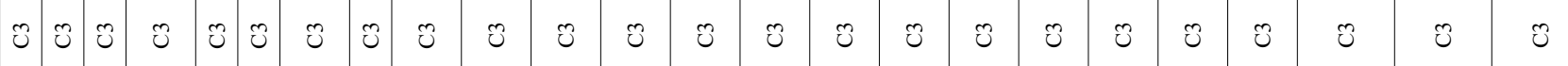

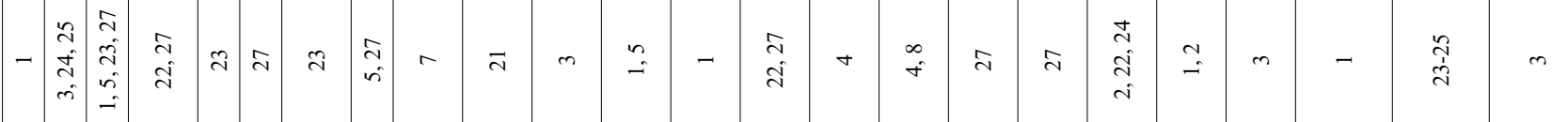

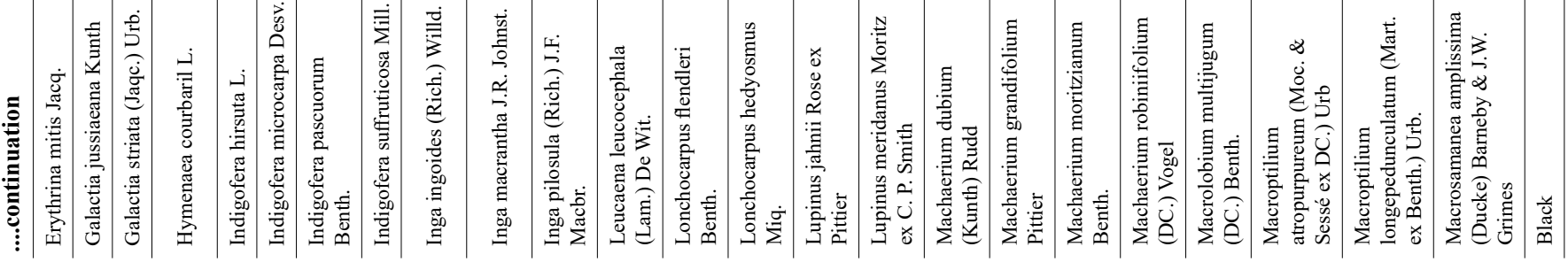


Ramírez, N. et al.

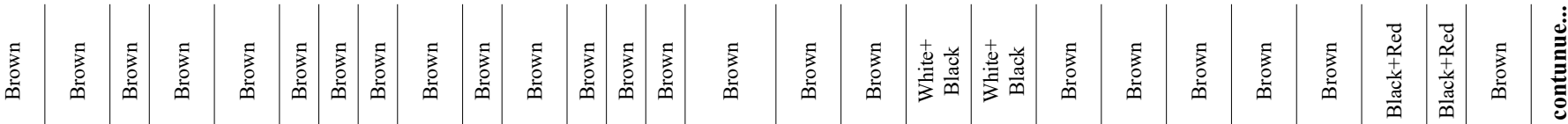

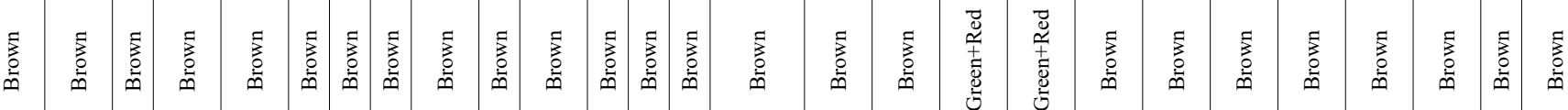

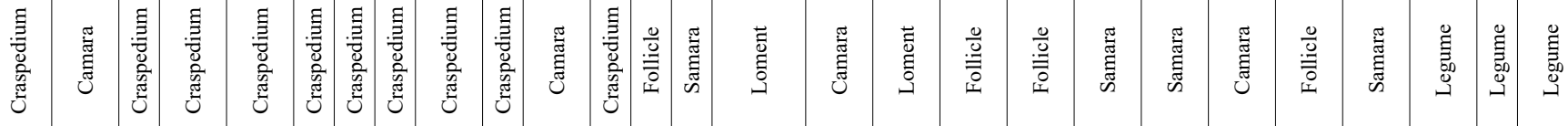

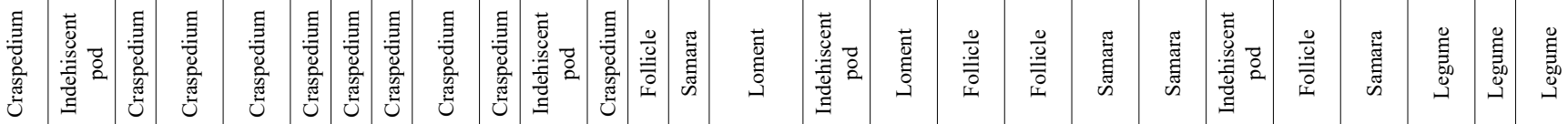

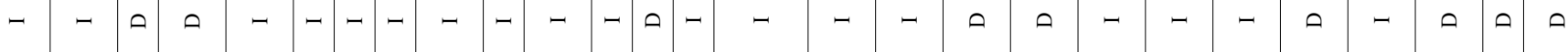
○ ○ $\Sigma$

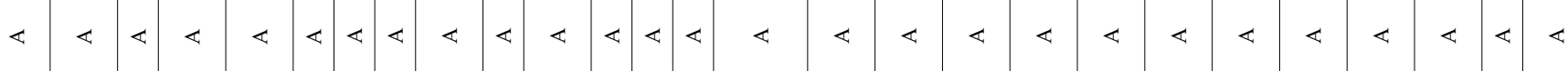

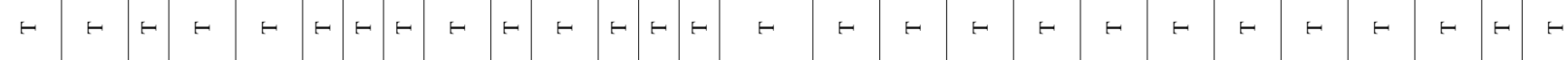

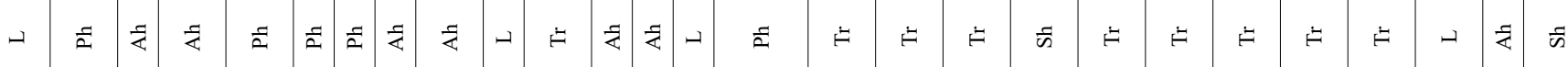

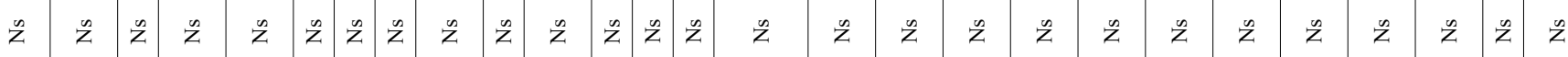

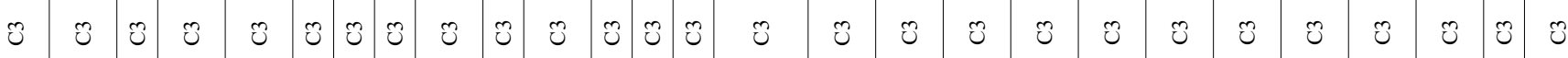

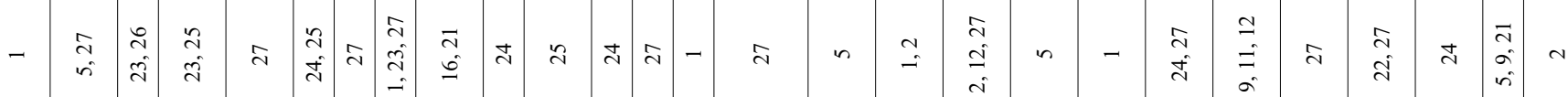

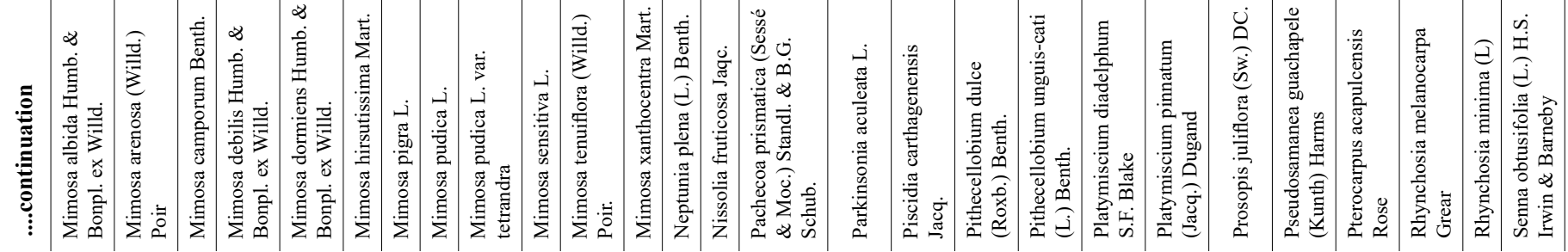




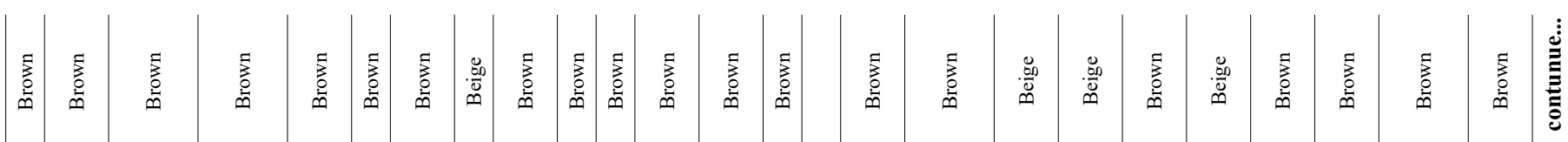

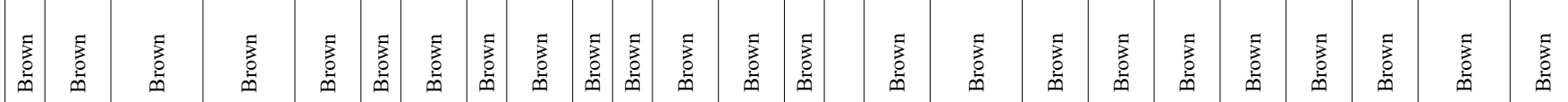

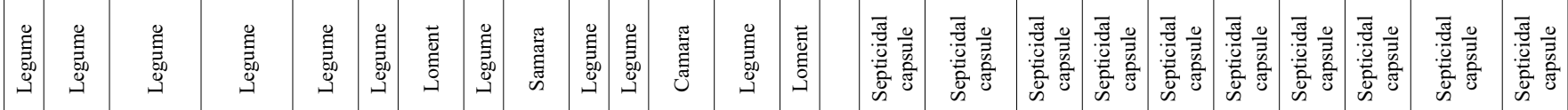

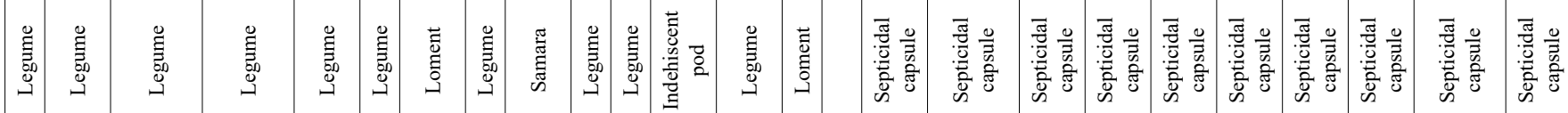
○

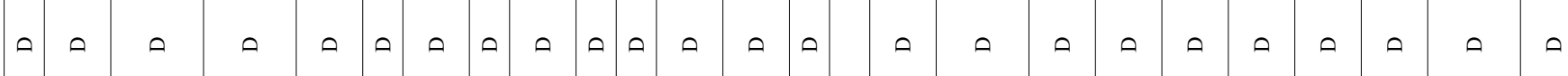

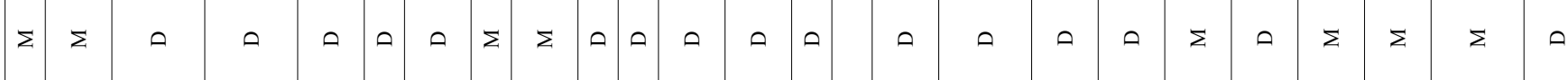

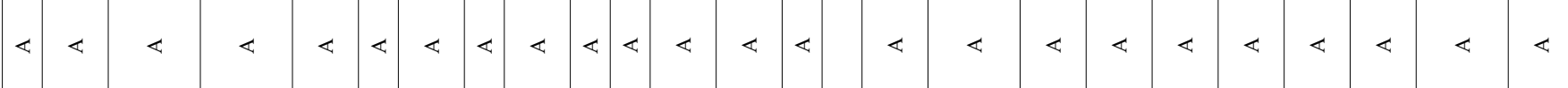

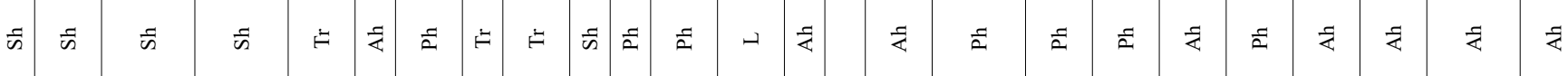

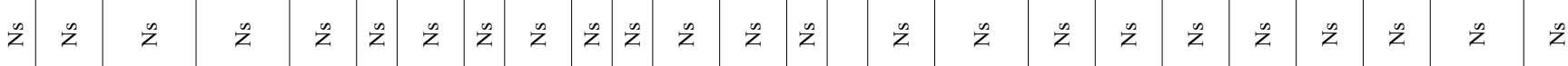

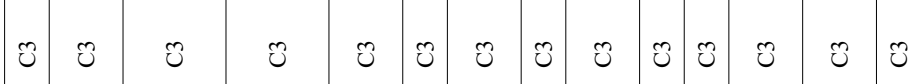

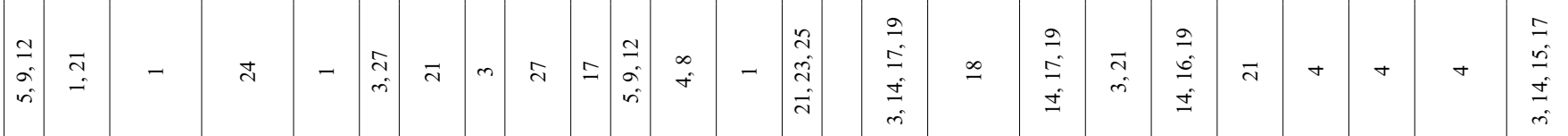

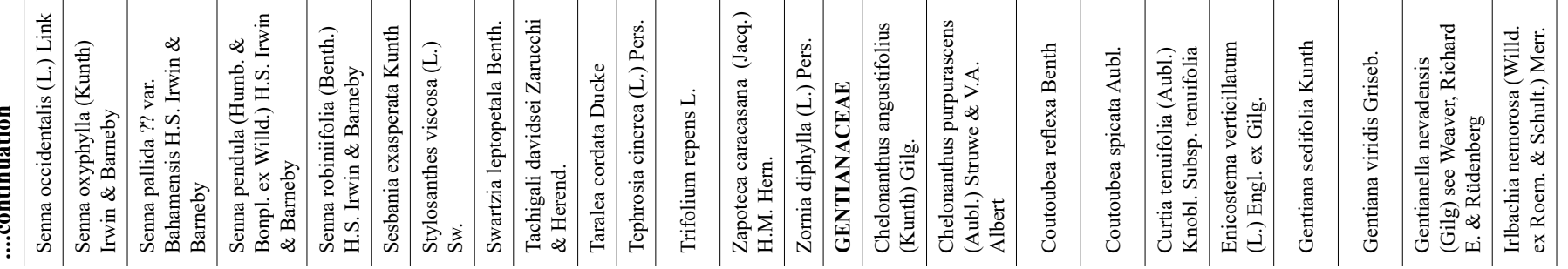


Ramírez, N. et al.

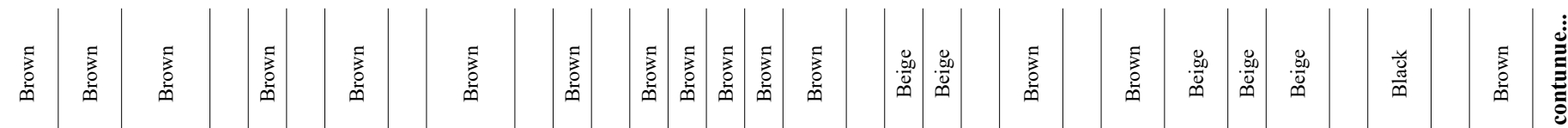

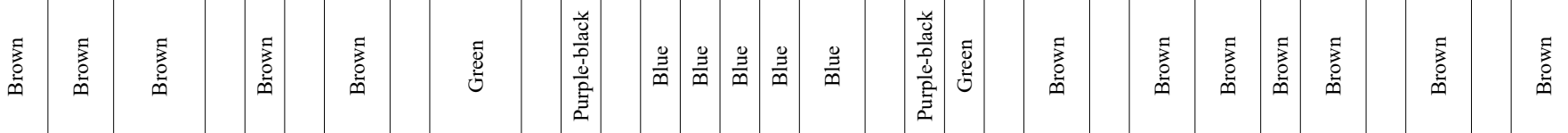

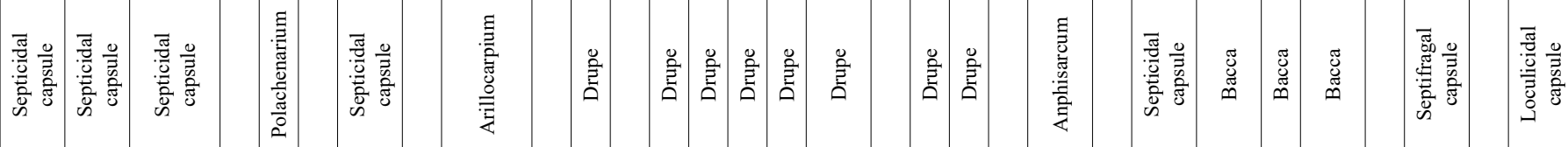

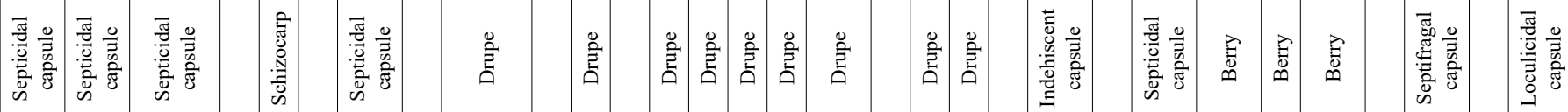

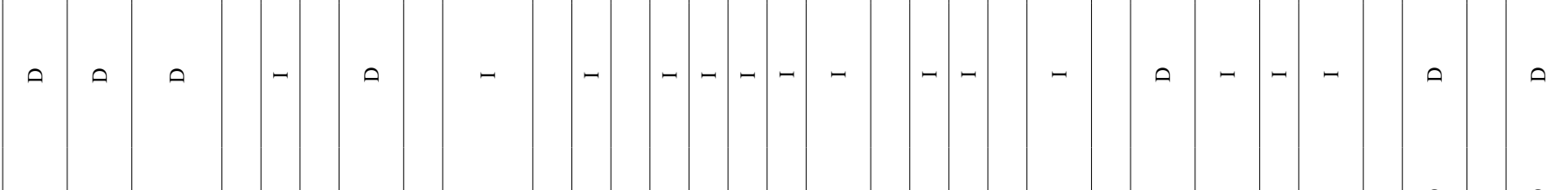

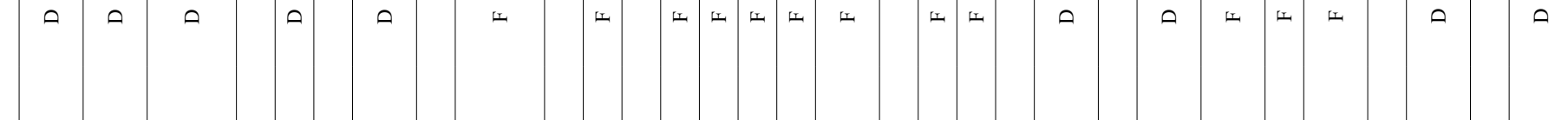
ค $\varangle \quad \varangle \quad<\quad<$ $+r$

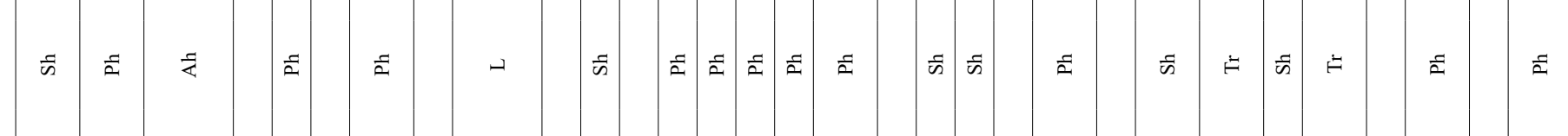

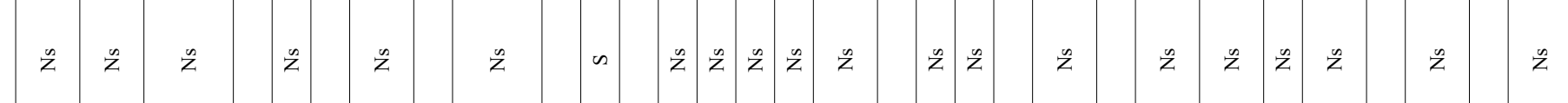

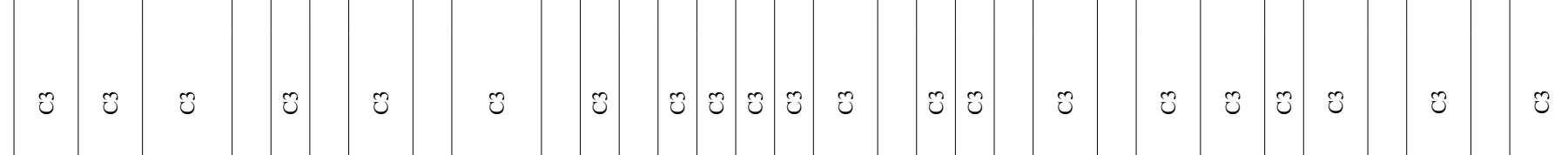

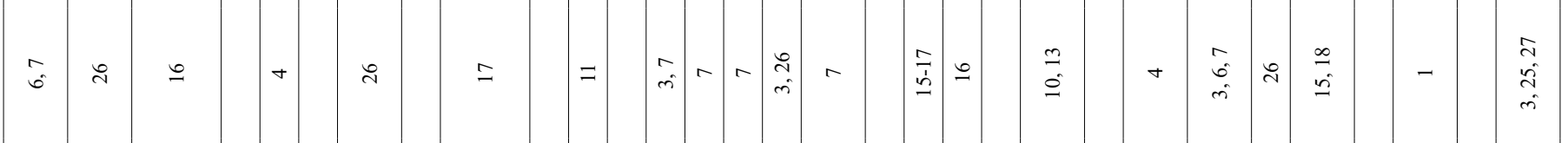

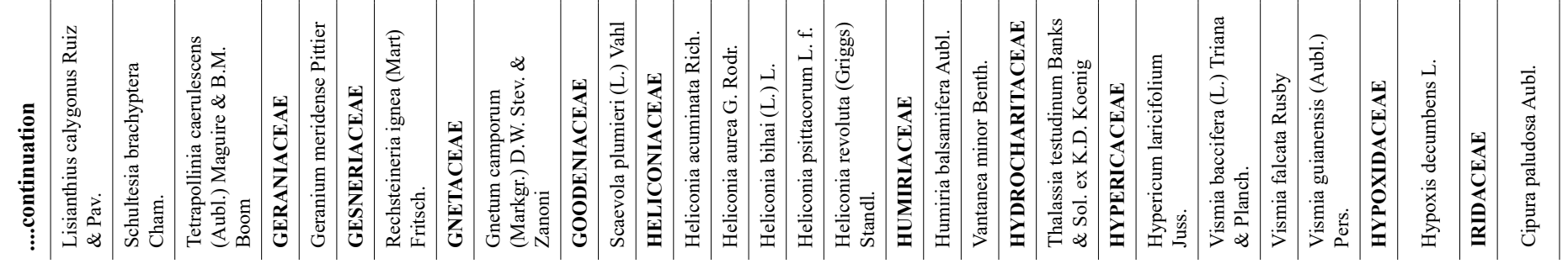




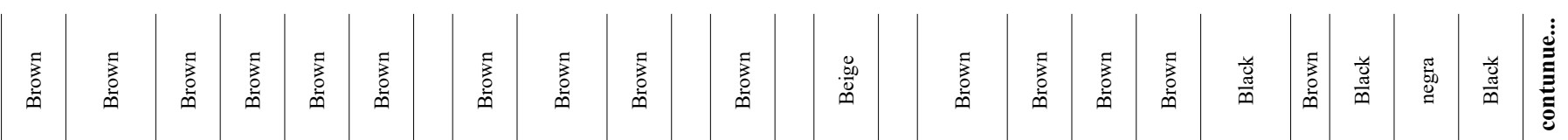

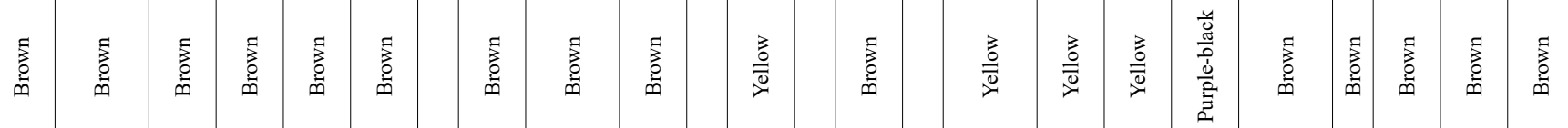

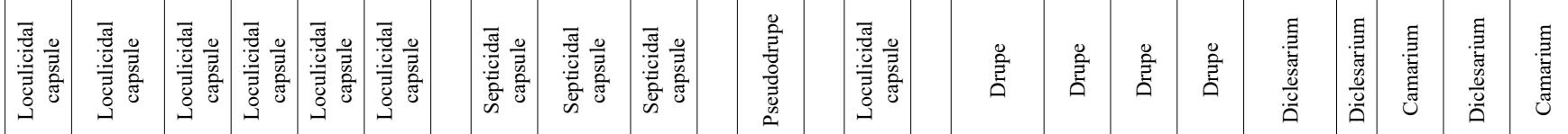

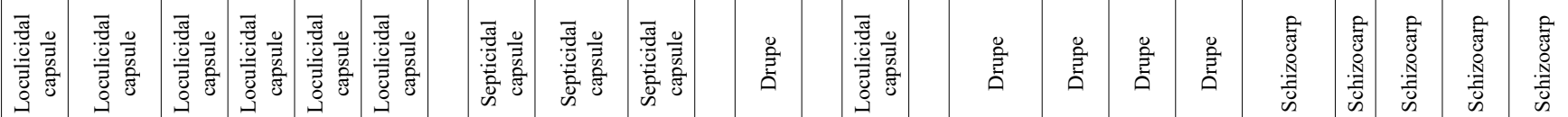
○ ○

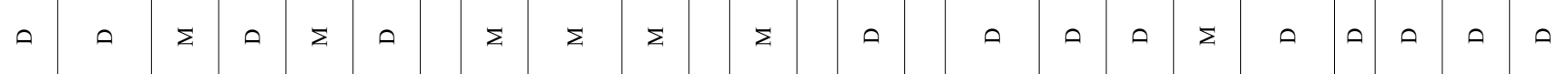

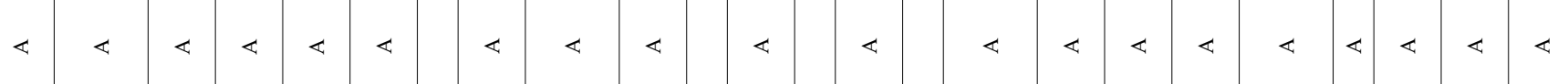

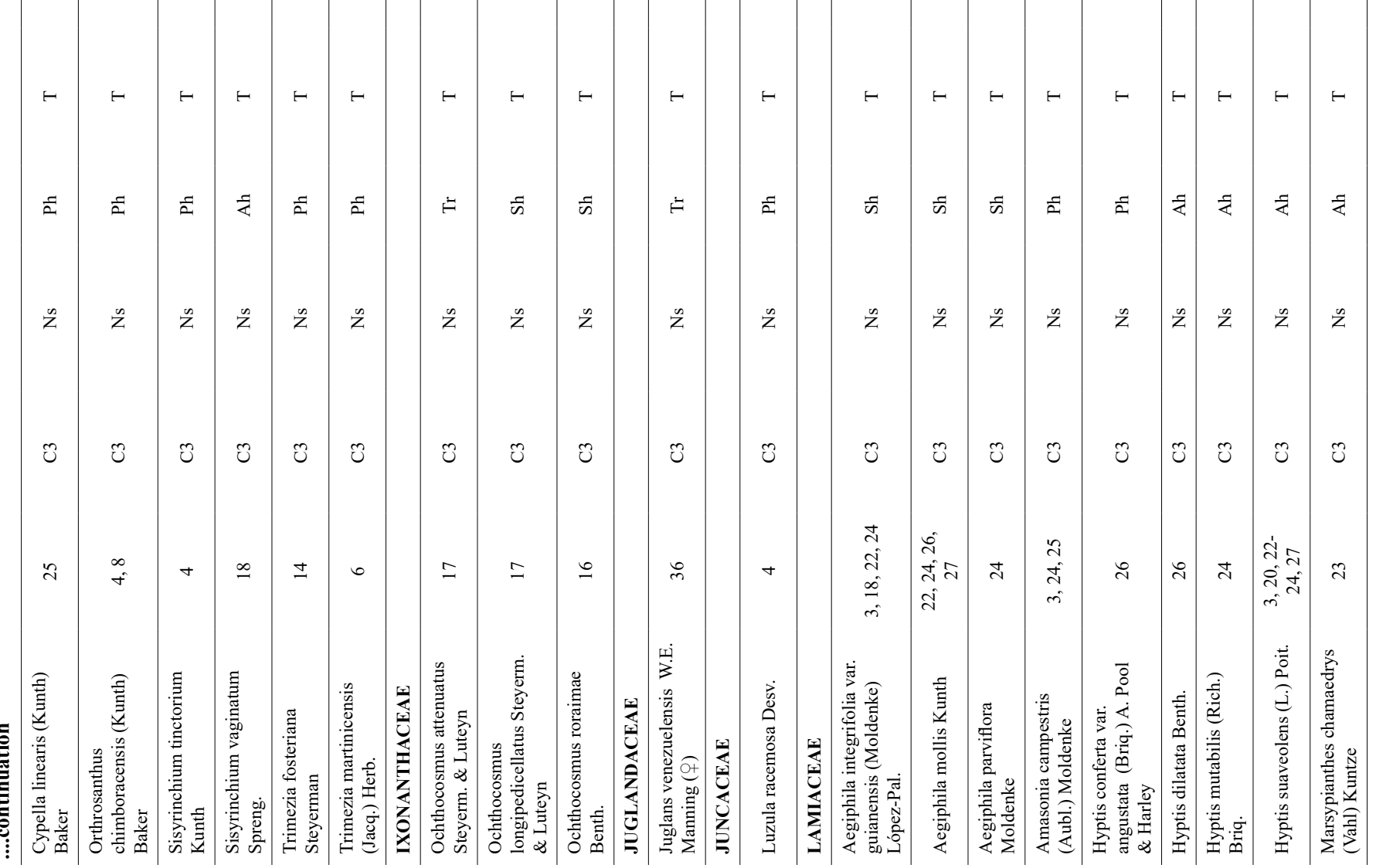


Ramírez, N. et al.

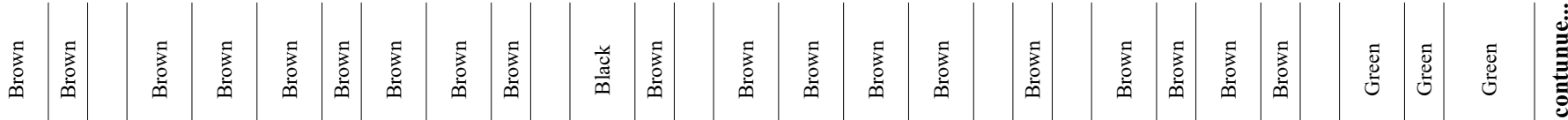

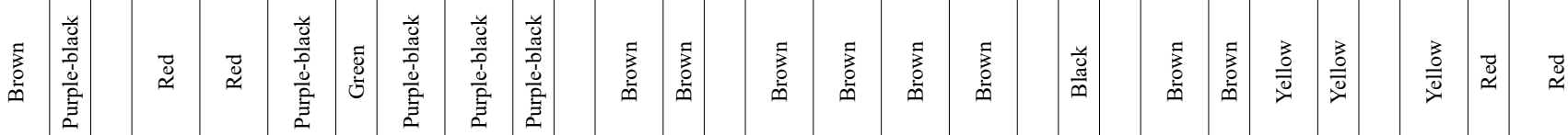

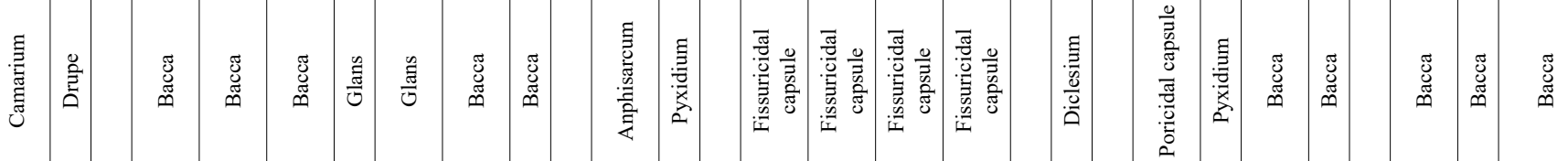

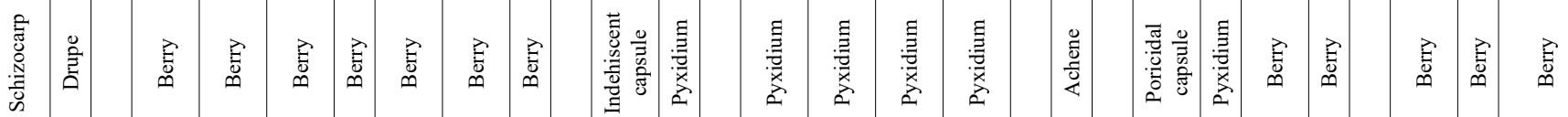

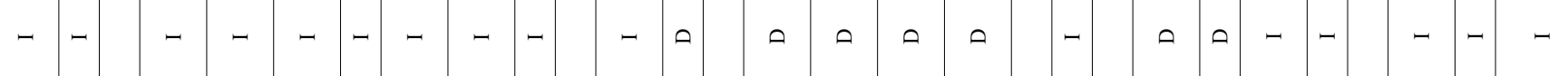
○ 出 出

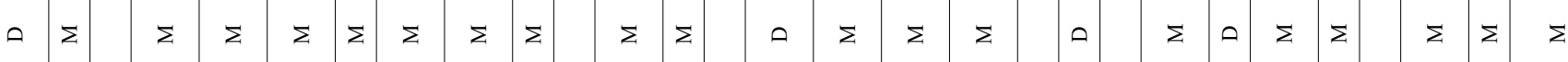

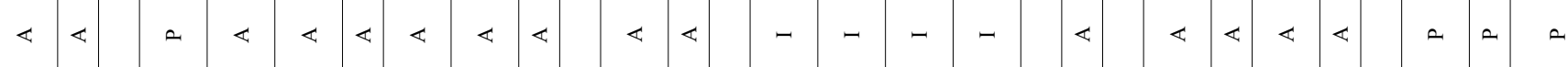

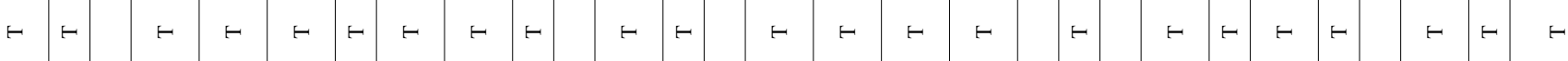
を

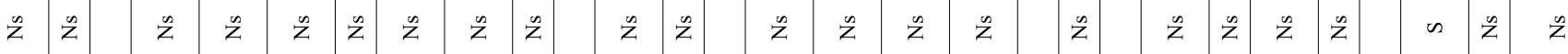

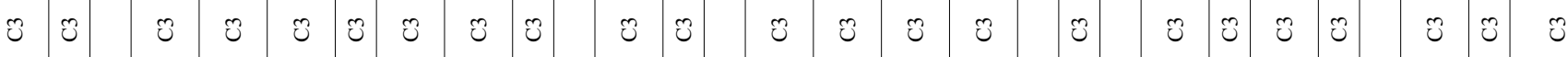

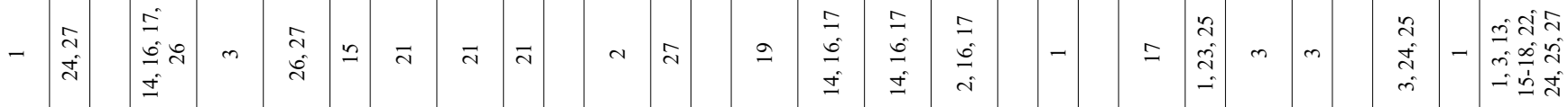

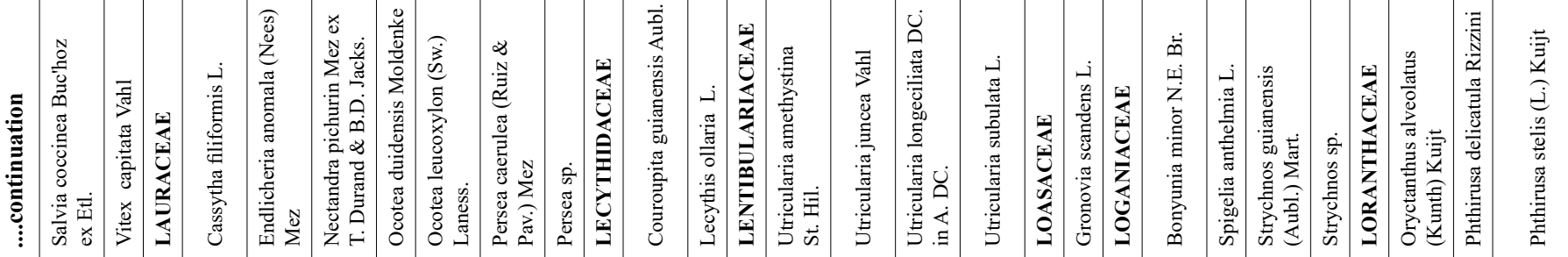




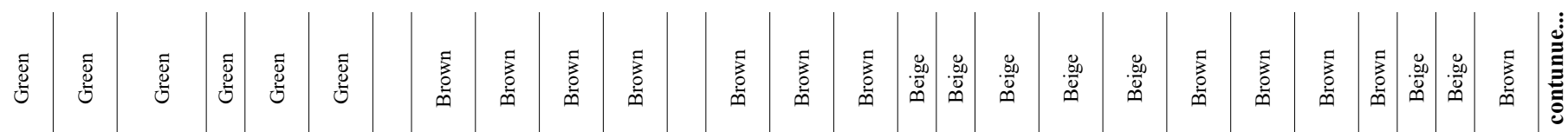

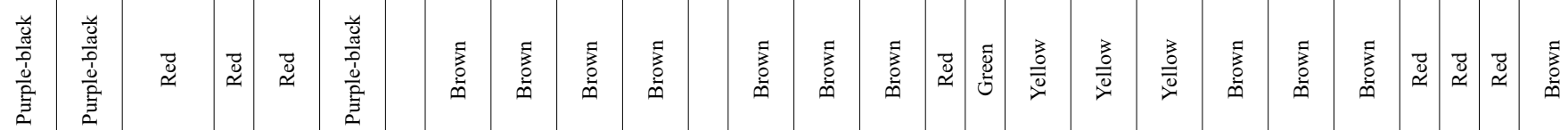

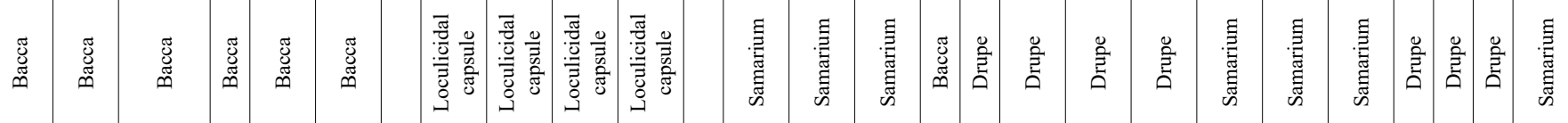

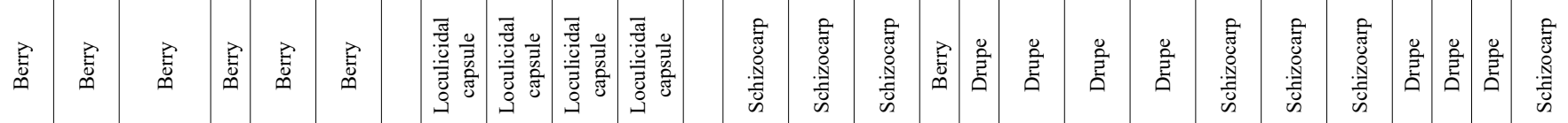

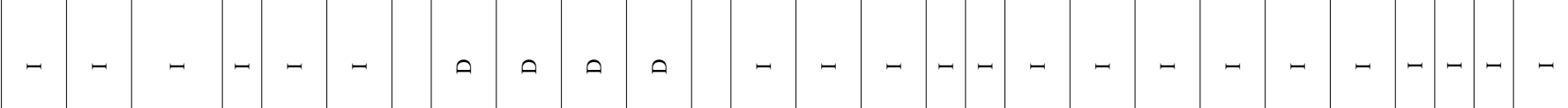
山 ш ш ш ш ш

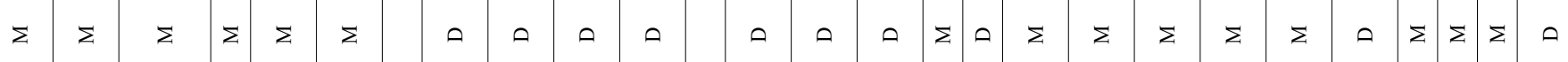

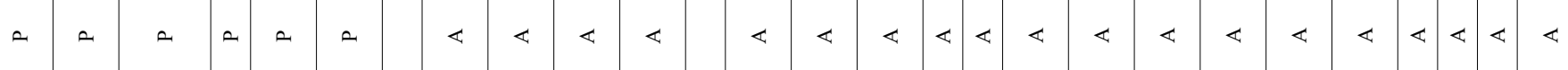

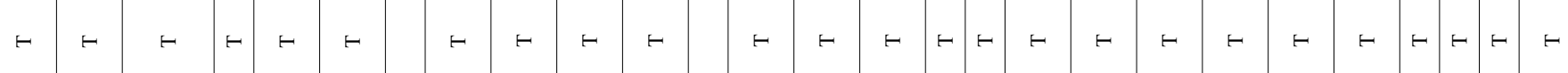

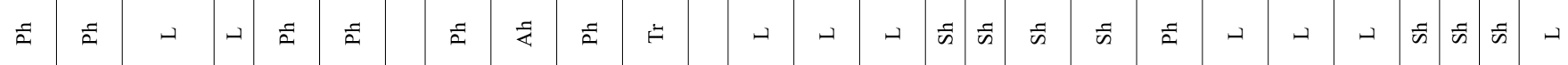

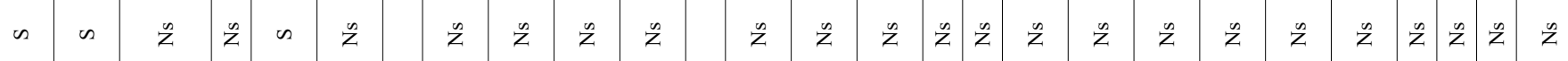

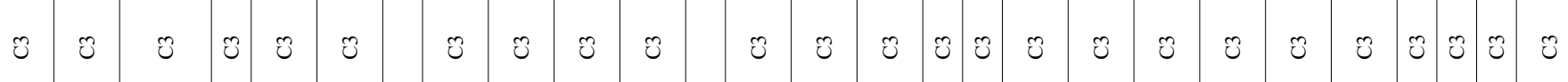

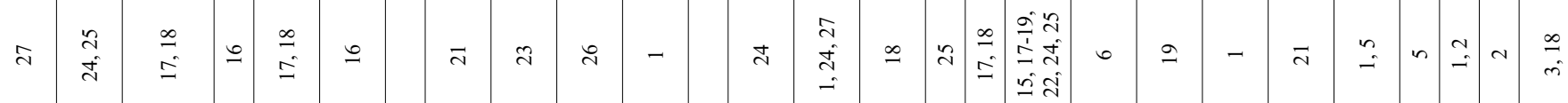

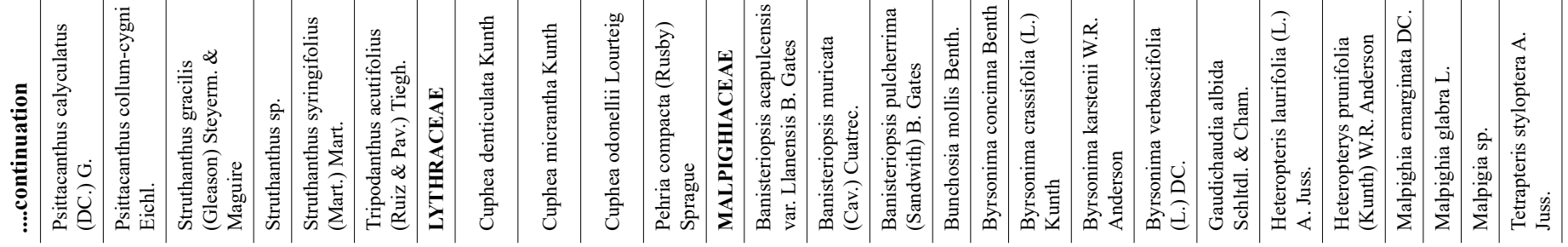


Ramírez, N. et al.

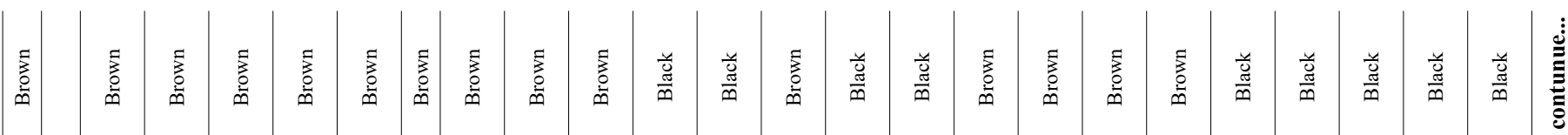

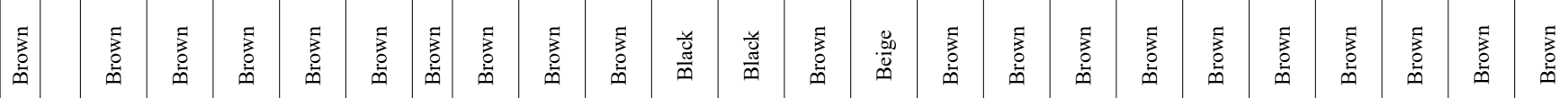

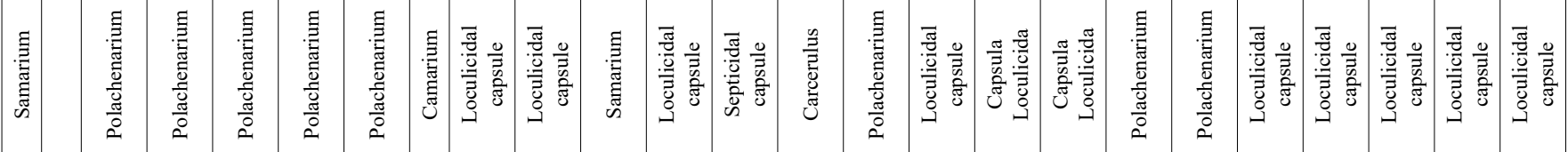

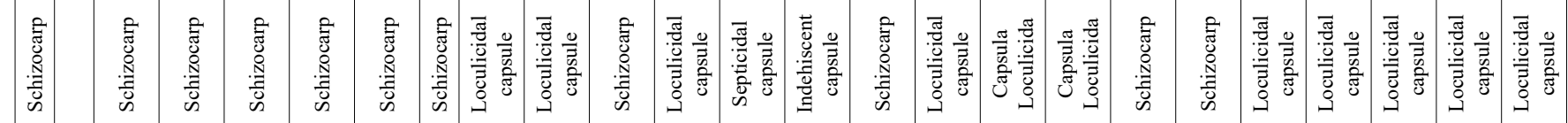

-0 -

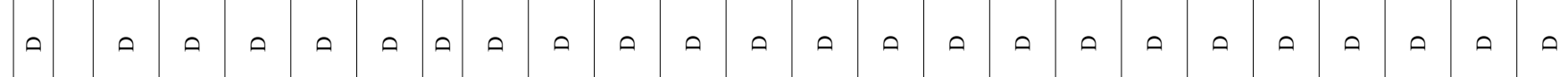

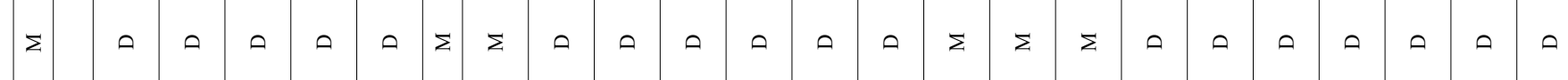

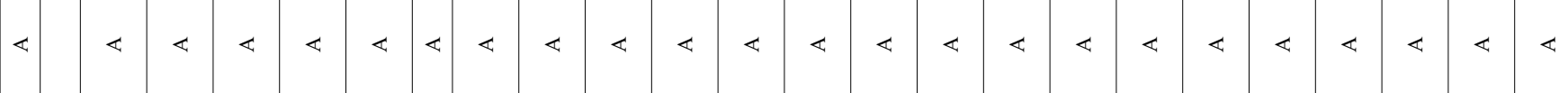

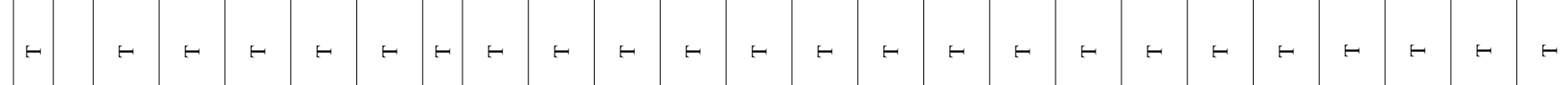

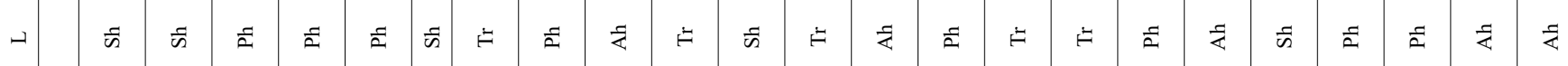

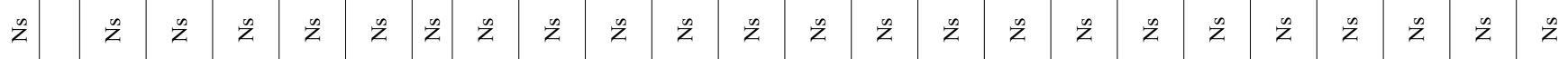

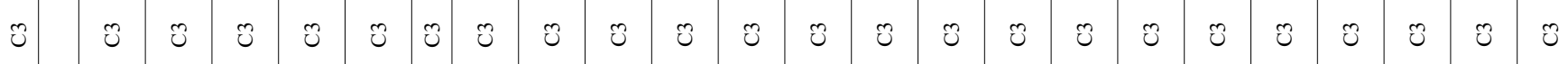

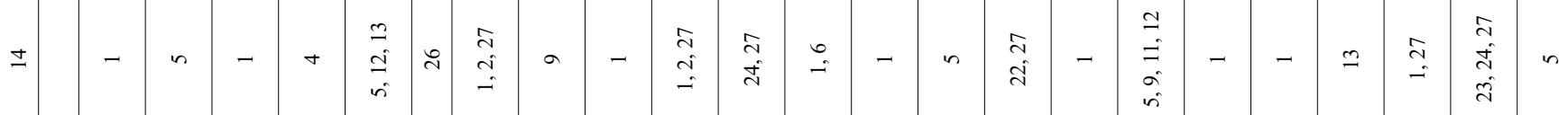

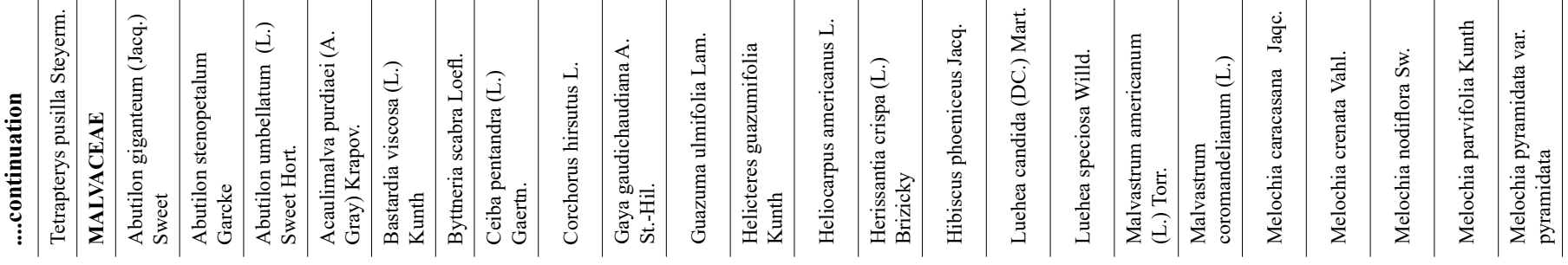




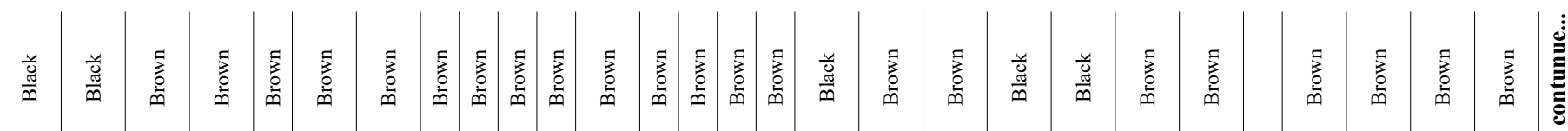

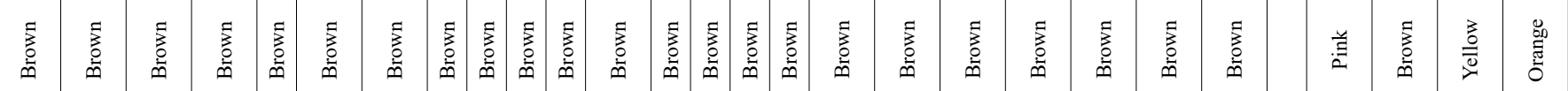

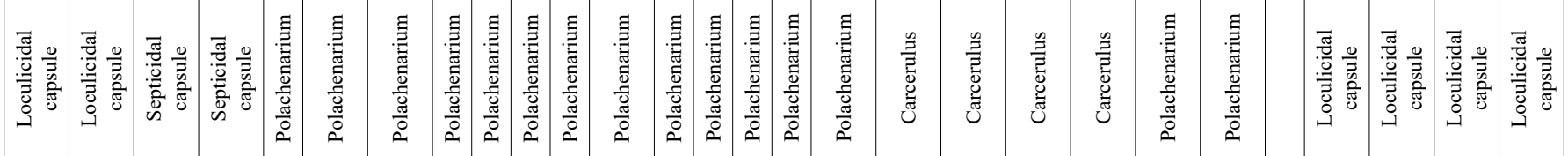

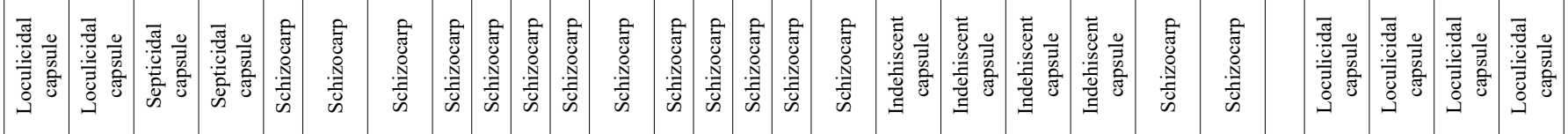

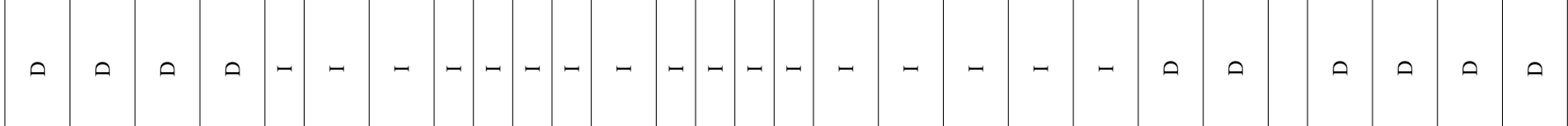

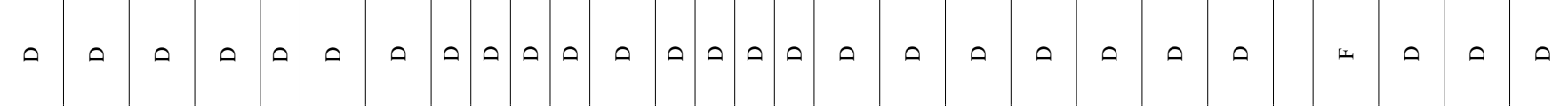

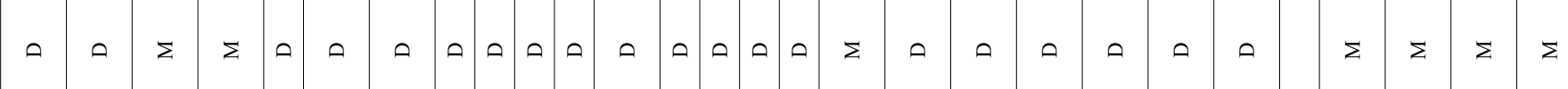

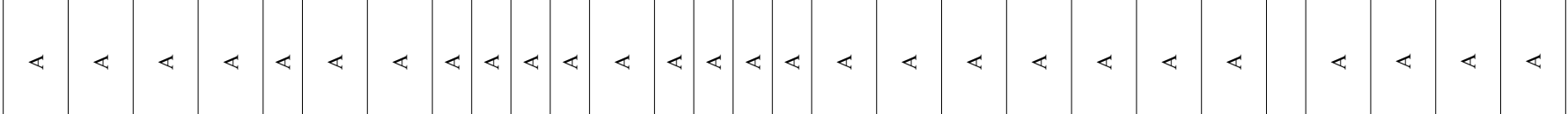

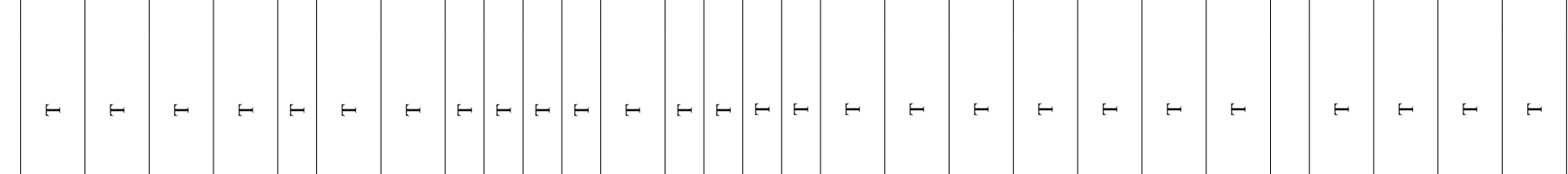

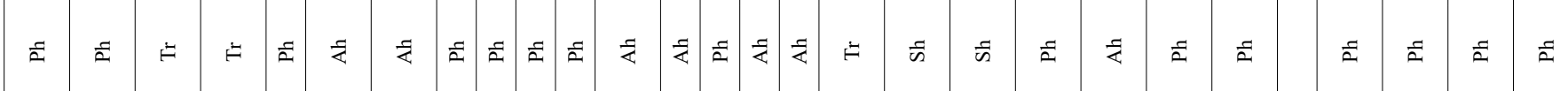

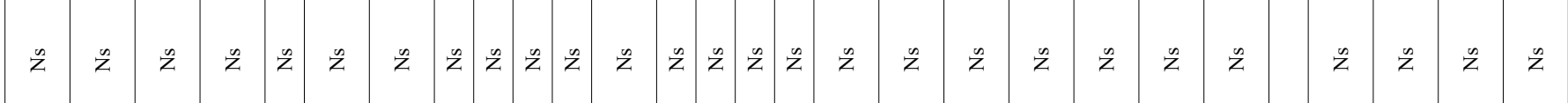

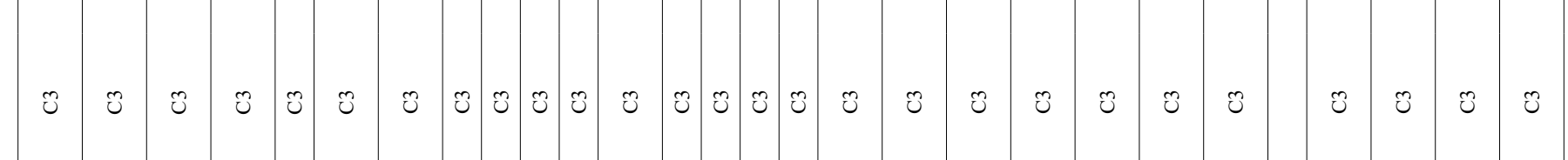

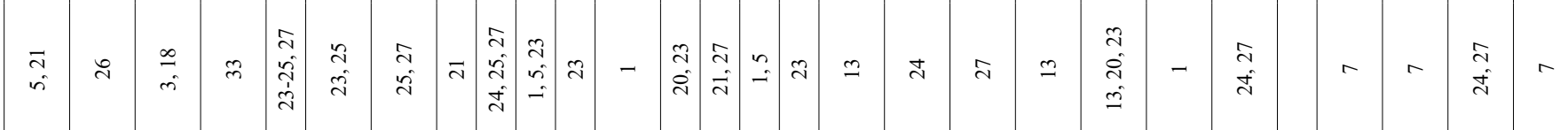

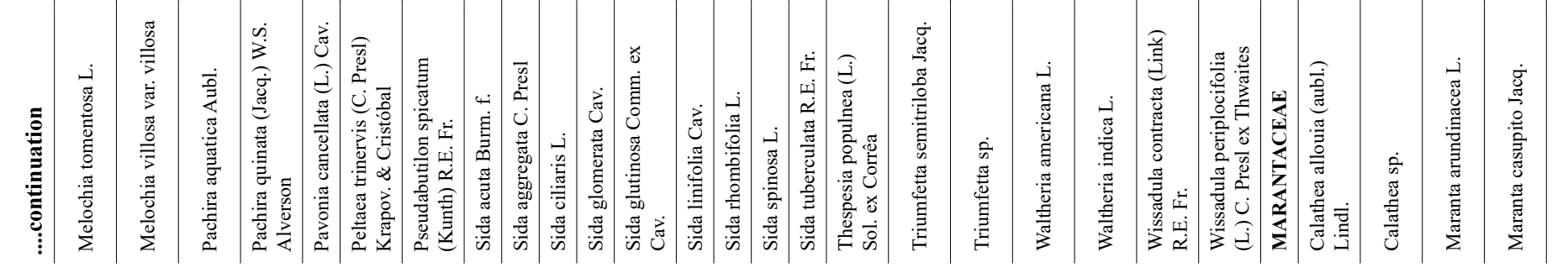


Ramírez, N. et al.

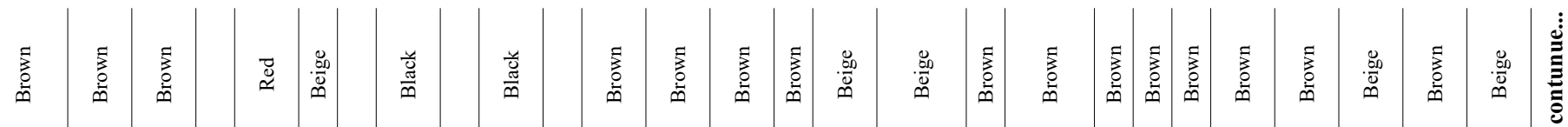

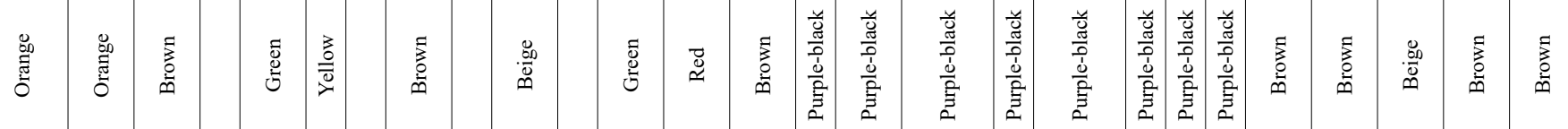

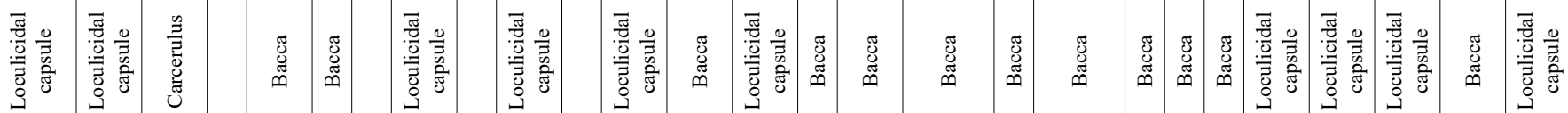

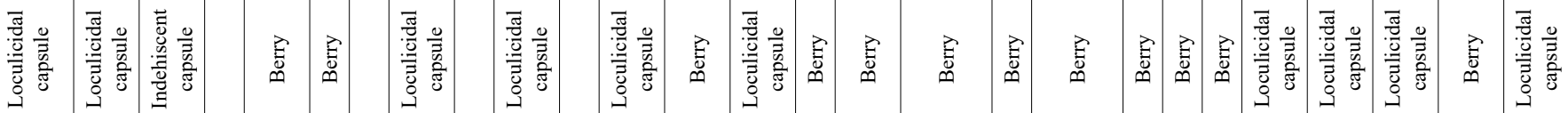
ค $ค-$

$\circ \quad \circ$

$\Sigma \quad \Sigma \quad \Sigma \quad \Sigma \quad \Sigma$

$\varangle \quad \varangle \quad \varangle \quad 4 \quad \varangle$

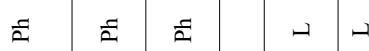

$\approx$

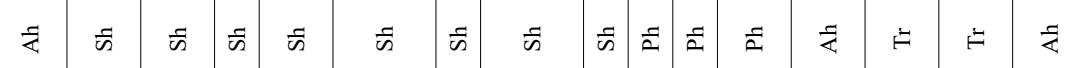

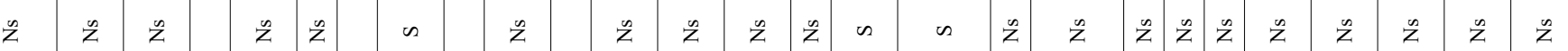

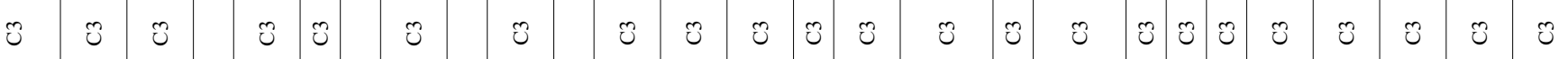

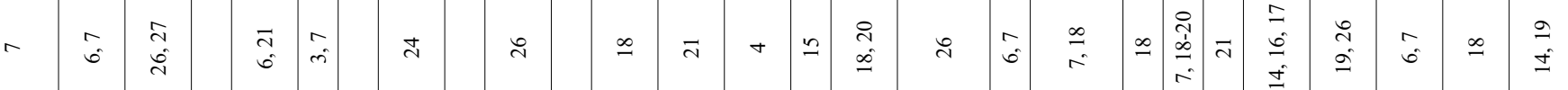

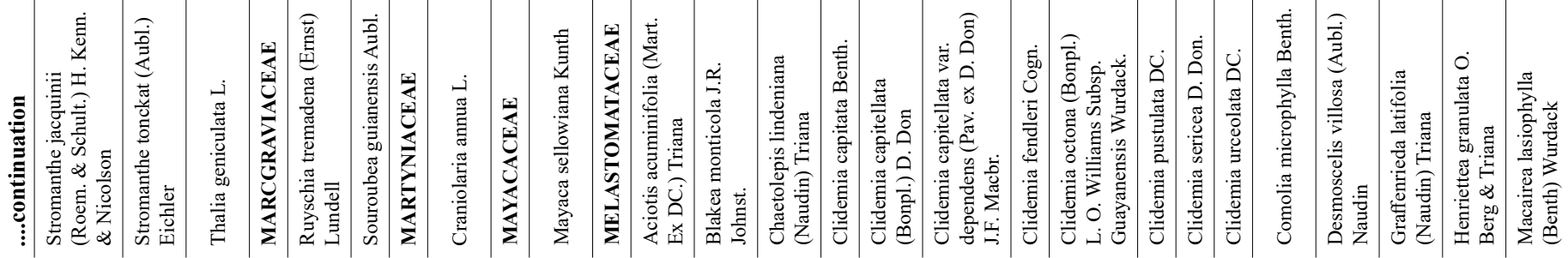




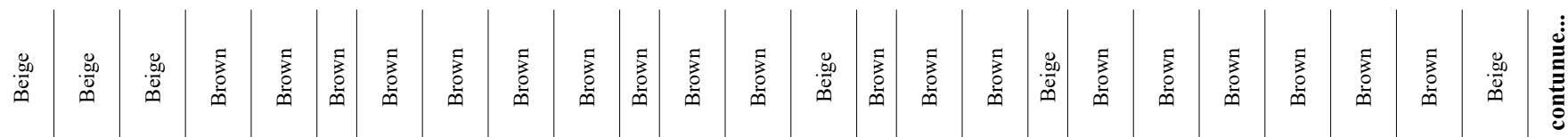

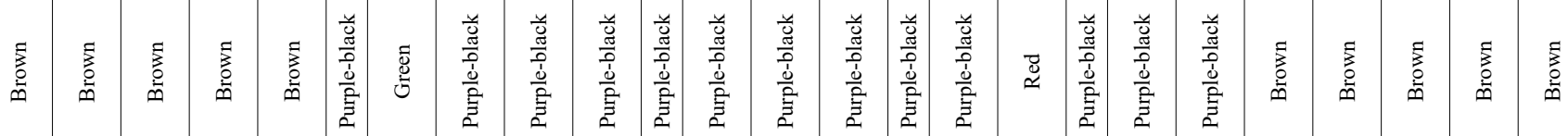

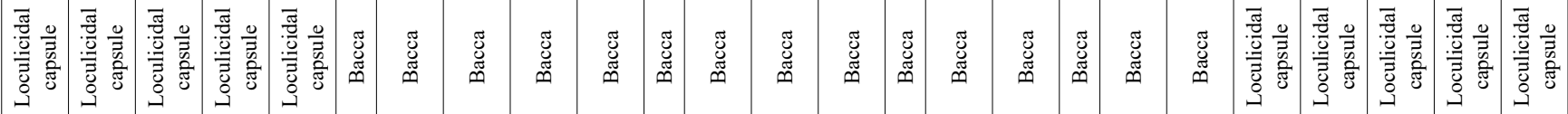

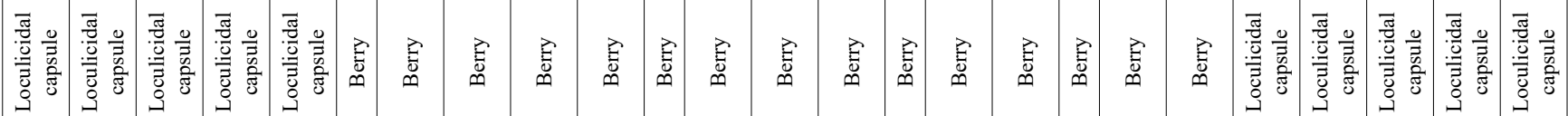

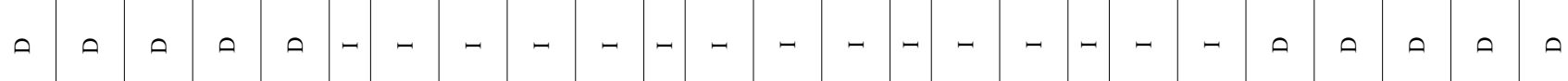
○

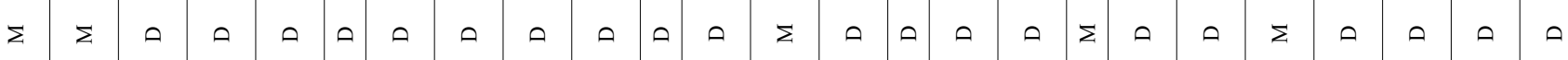

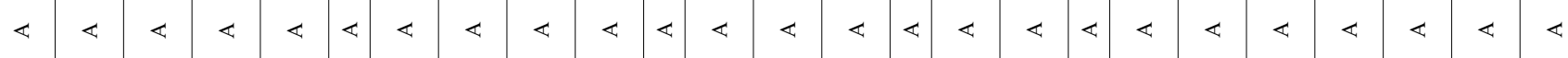

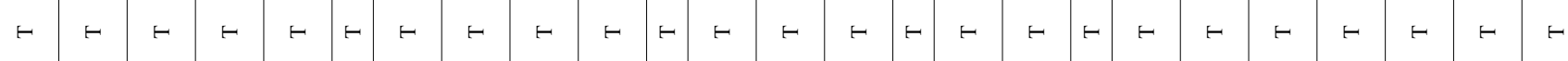

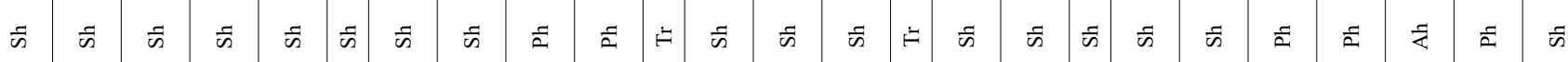

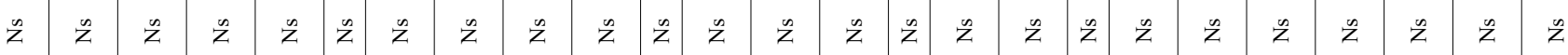

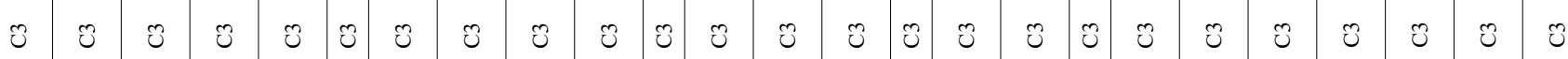

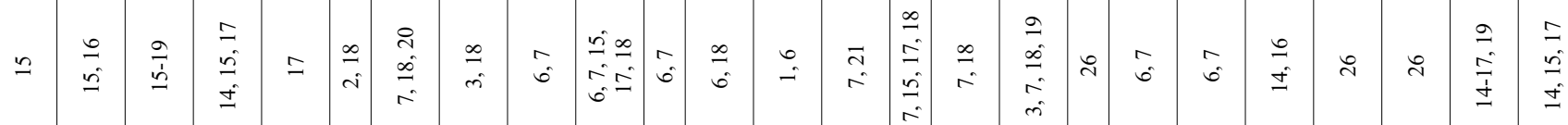

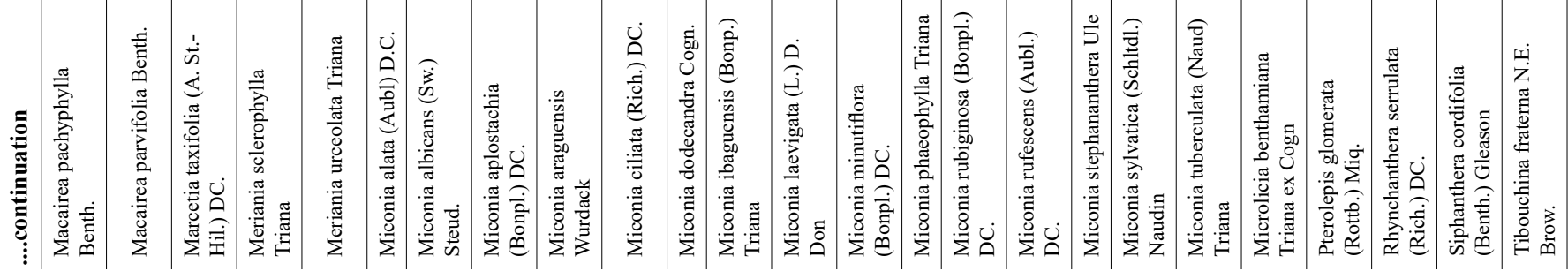


Ramírez, N. et al.

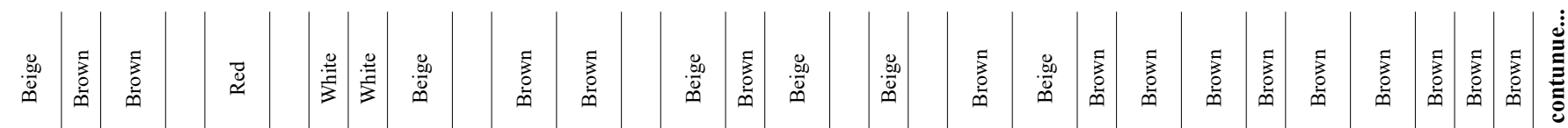

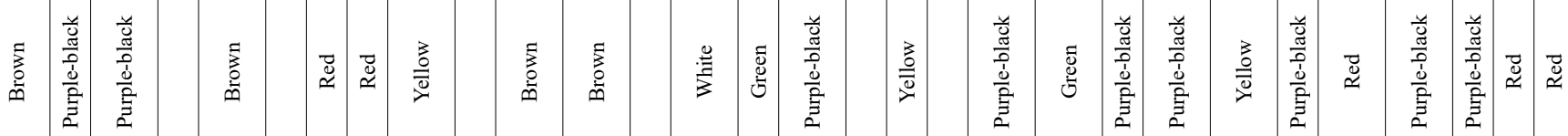

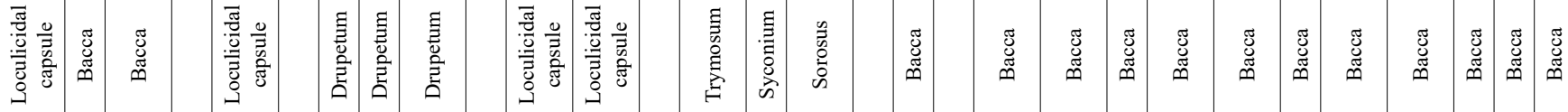

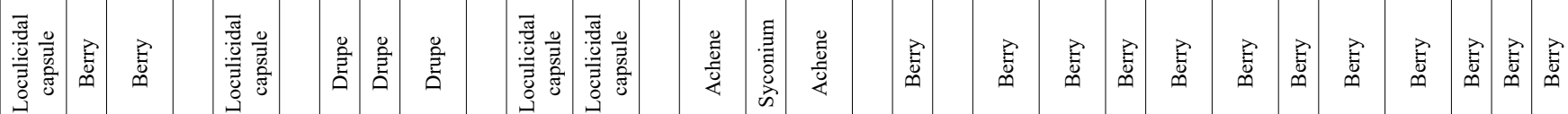

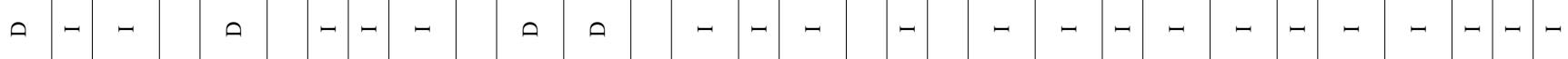

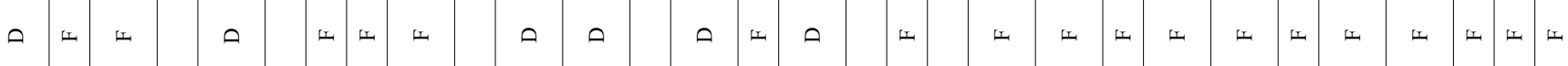

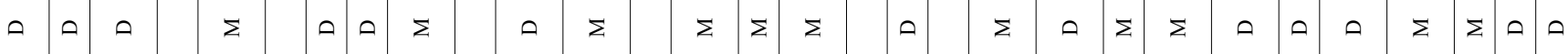

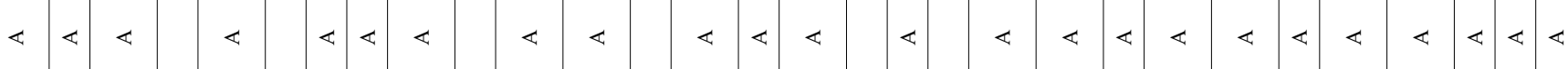
h H H

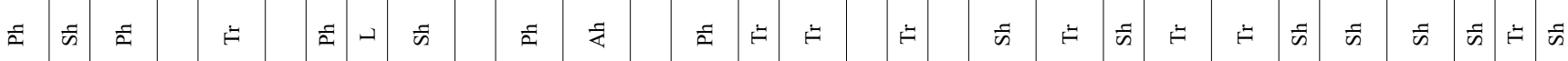

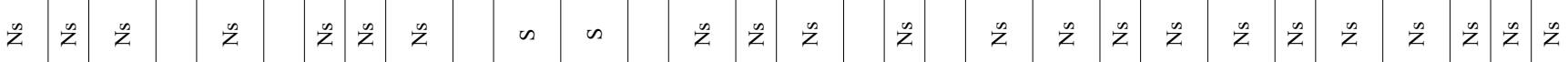

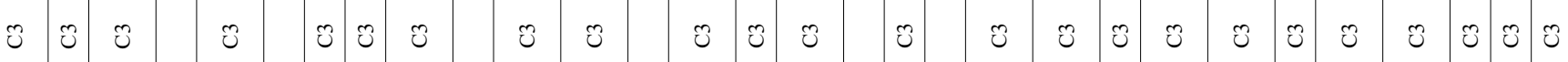

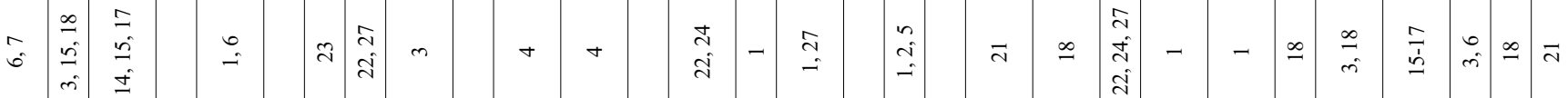

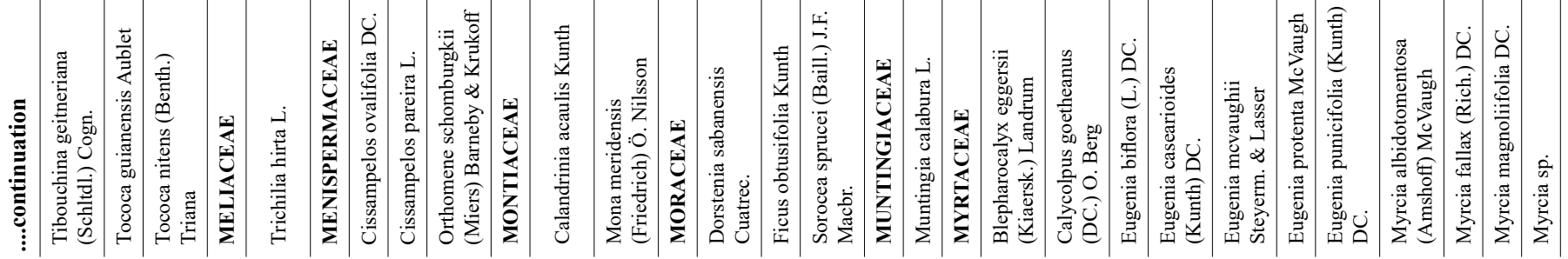




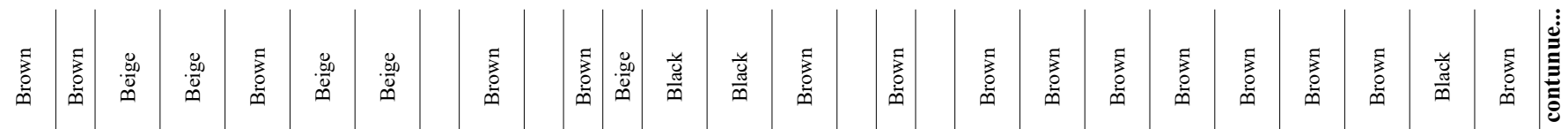

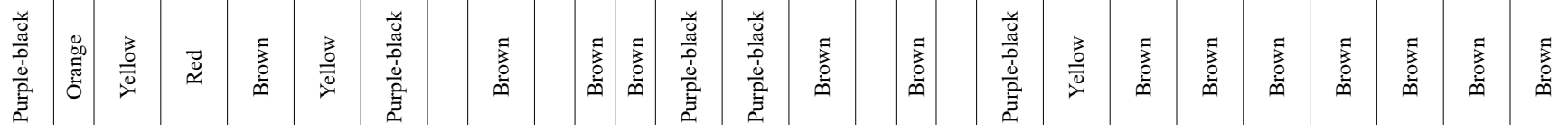

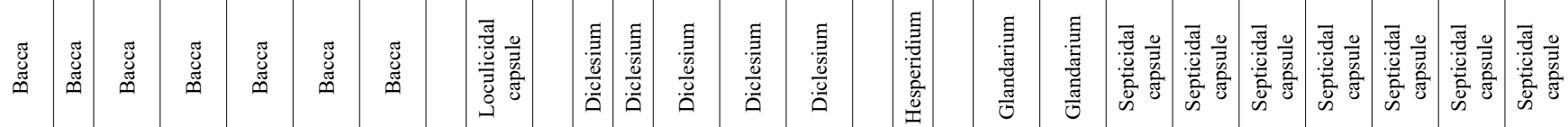

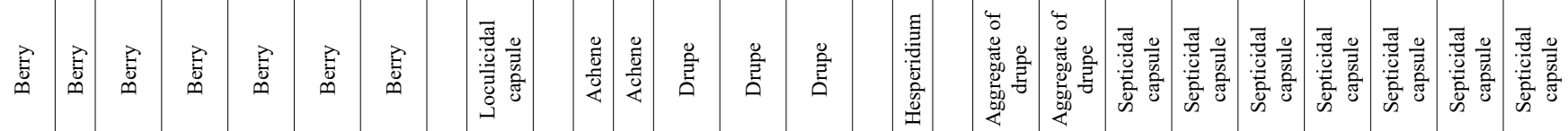

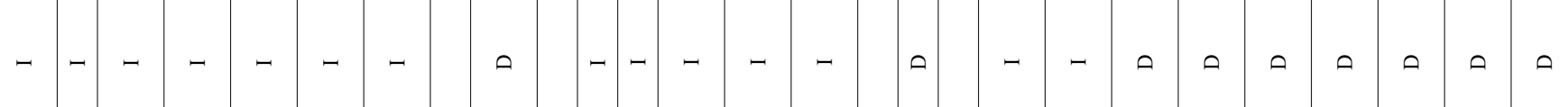

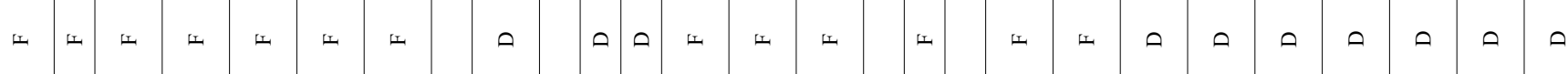

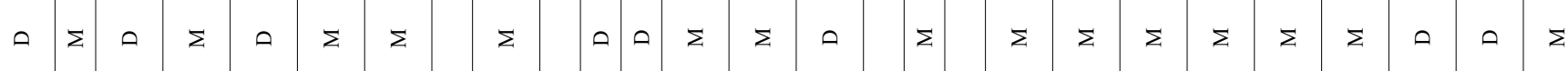

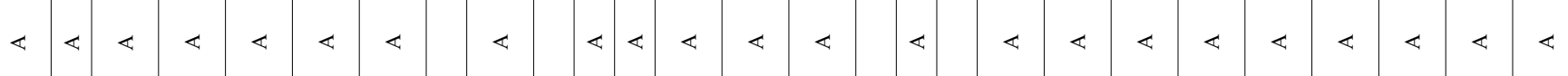

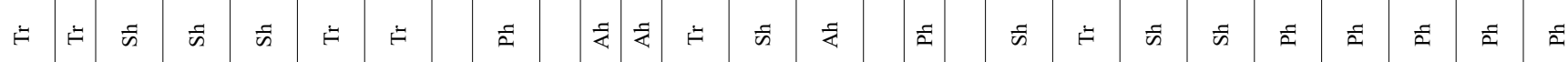

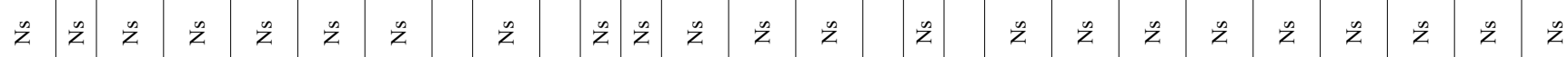

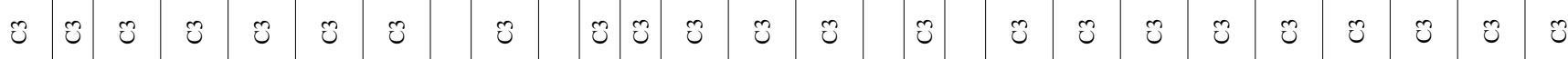

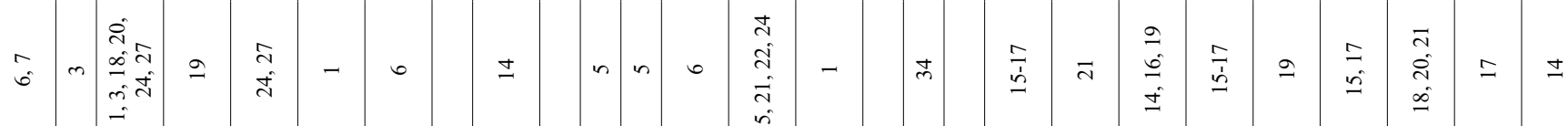

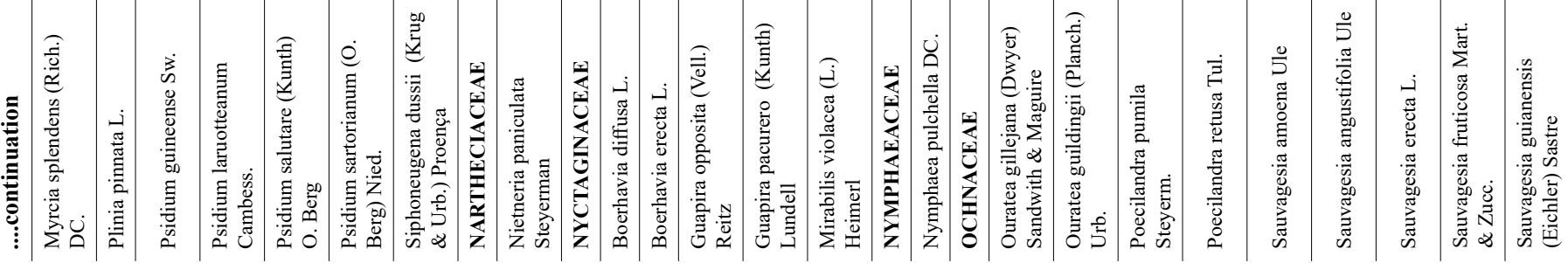




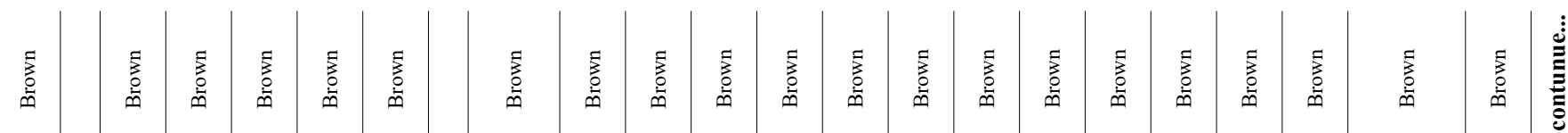

总总

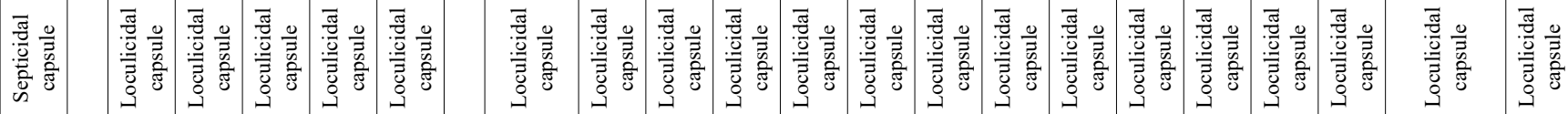

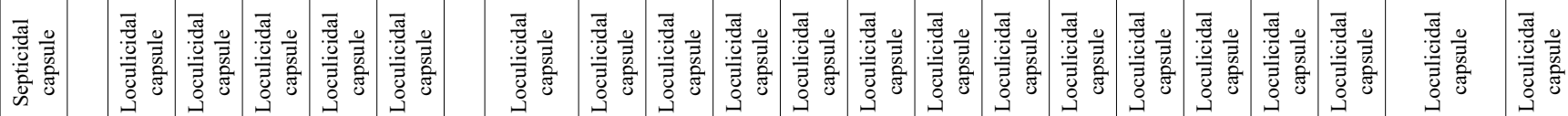

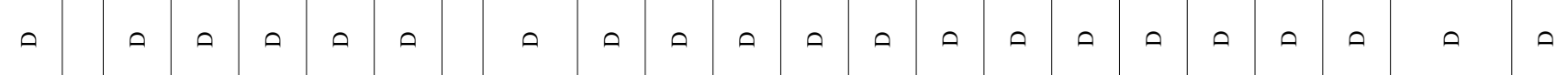

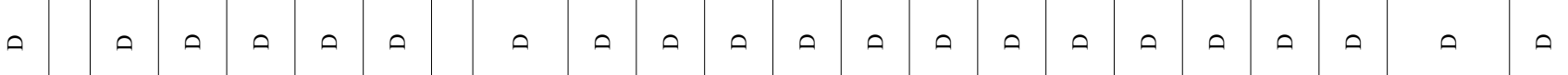

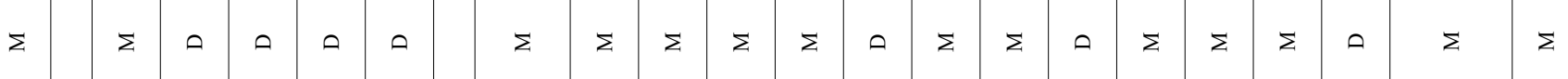

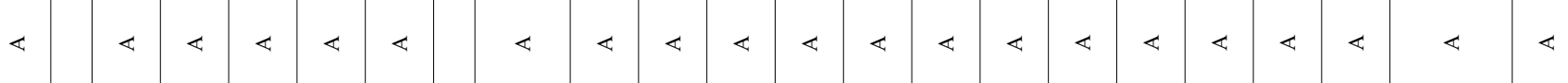

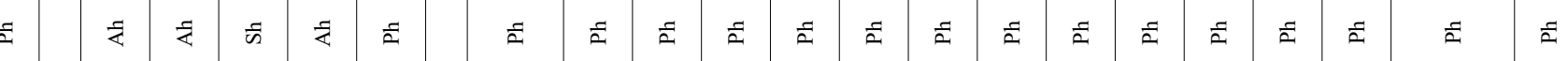

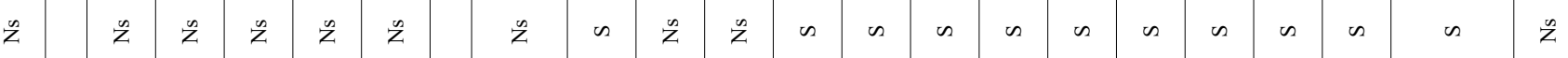

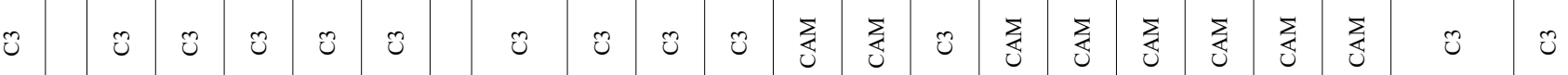

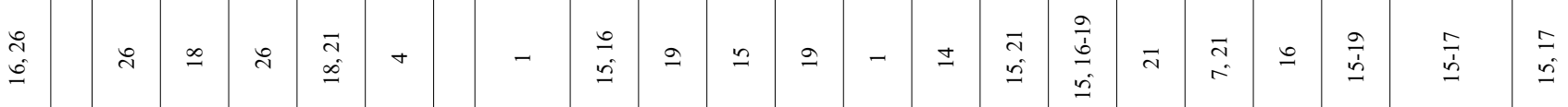

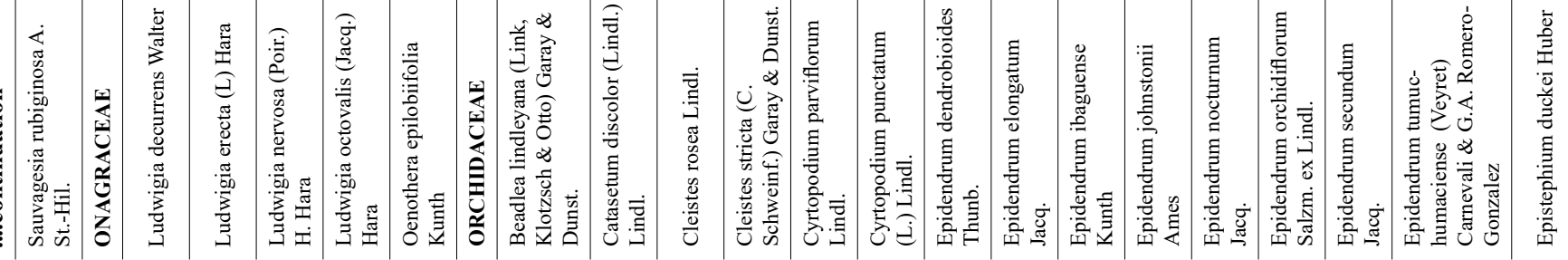




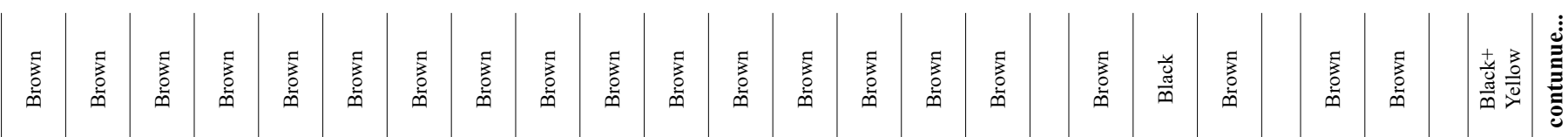

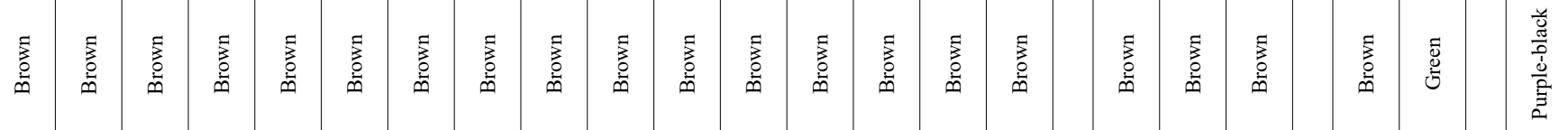

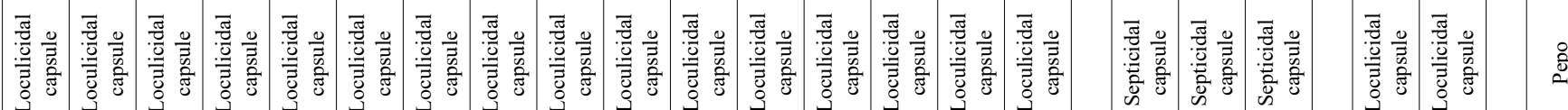

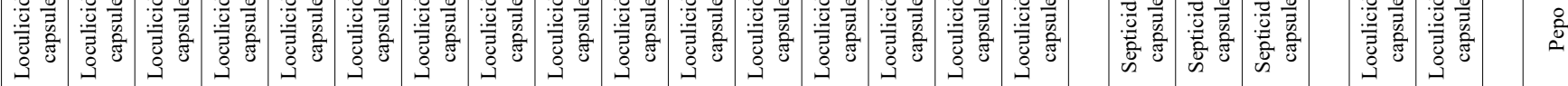

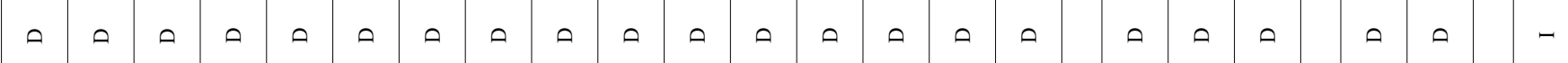

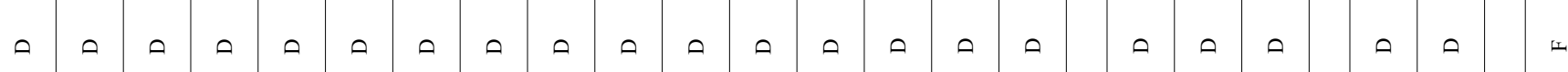

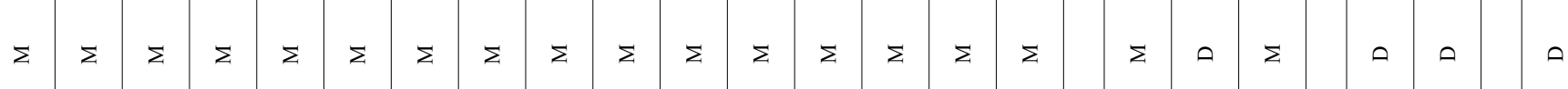

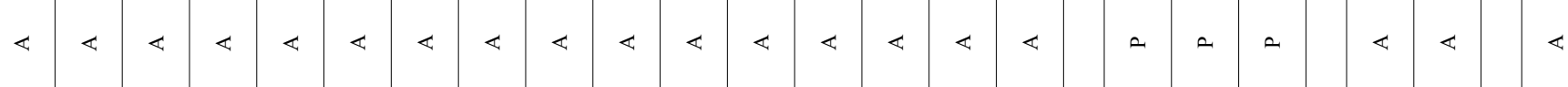

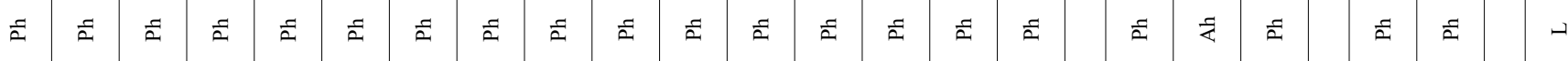

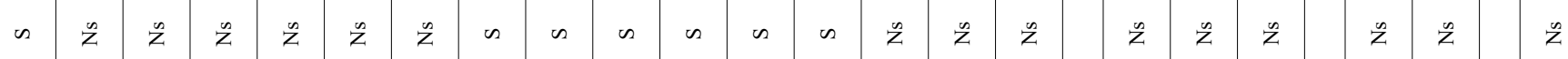

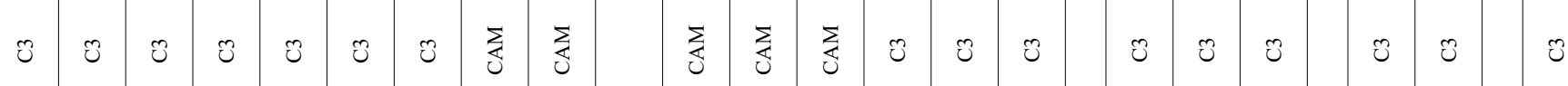

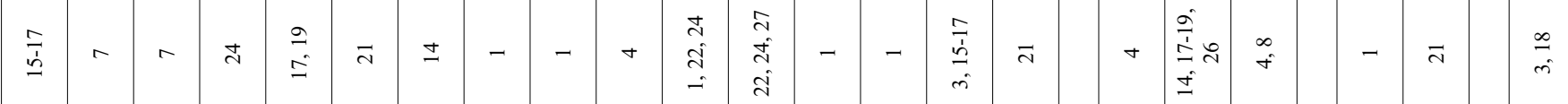

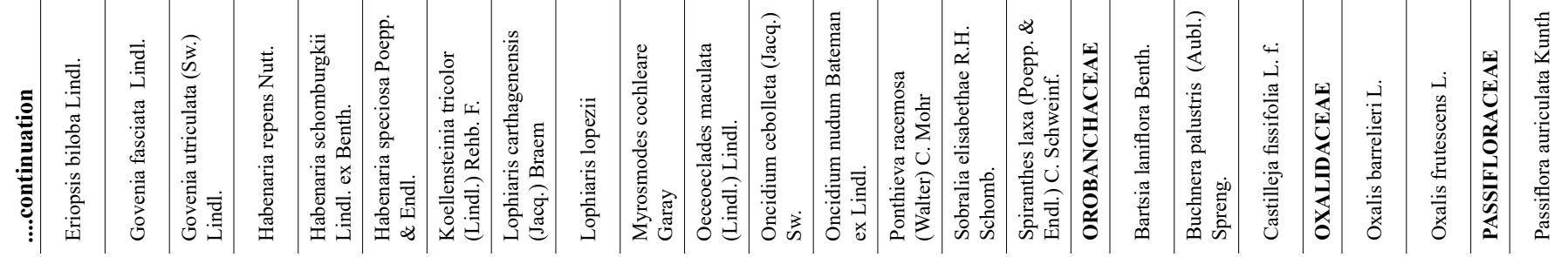


Ramírez, N. et al.

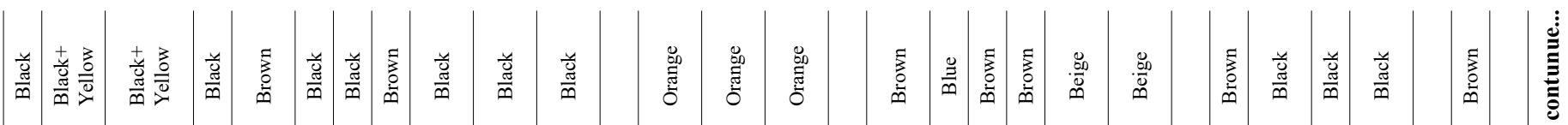

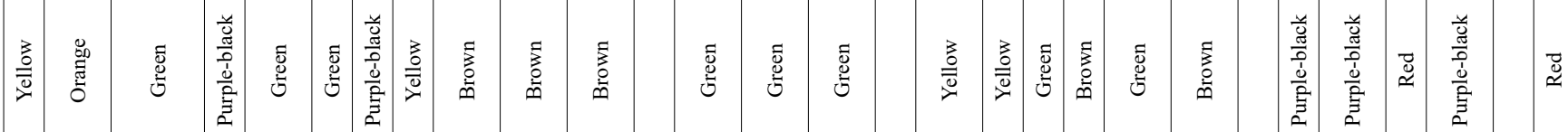

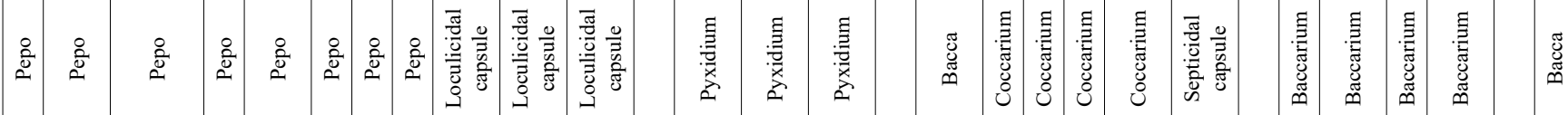

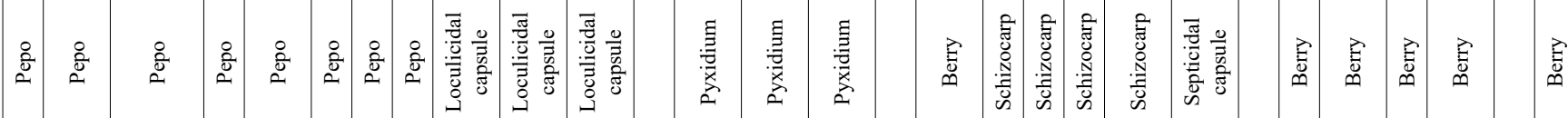
\begin{tabular}{rl|llllllllllllllllllllllllll}
- & - & - & - & - & - & - & 0 & 0 & 0 & 0 & 0 & 0 & - & 0 & 0 & 0 & 0 & 0 & - & - & - & - & - & -
\end{tabular} ш ш ш ш ш ш ш ш ш

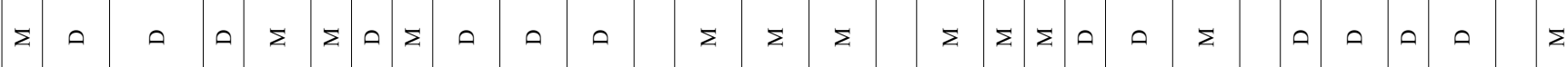

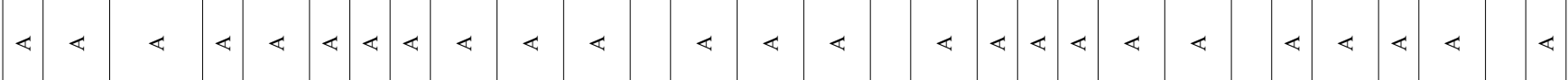
H H H H H H H H H H

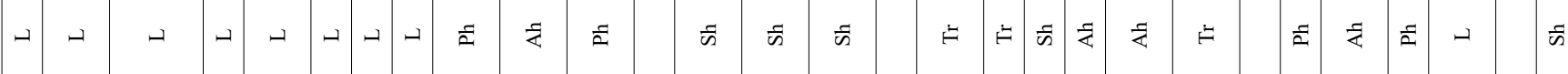

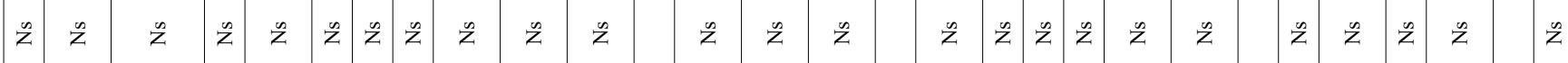

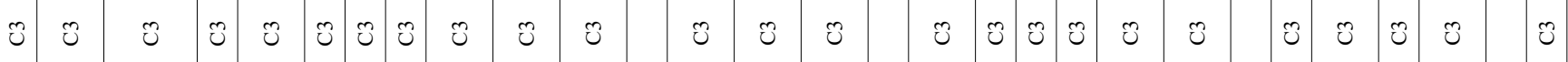

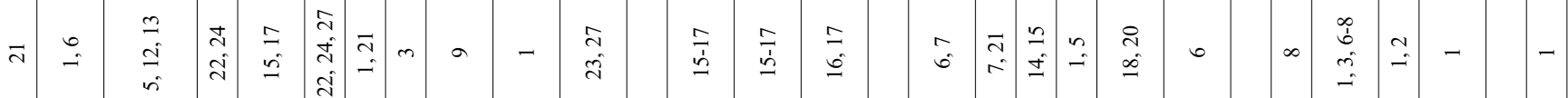

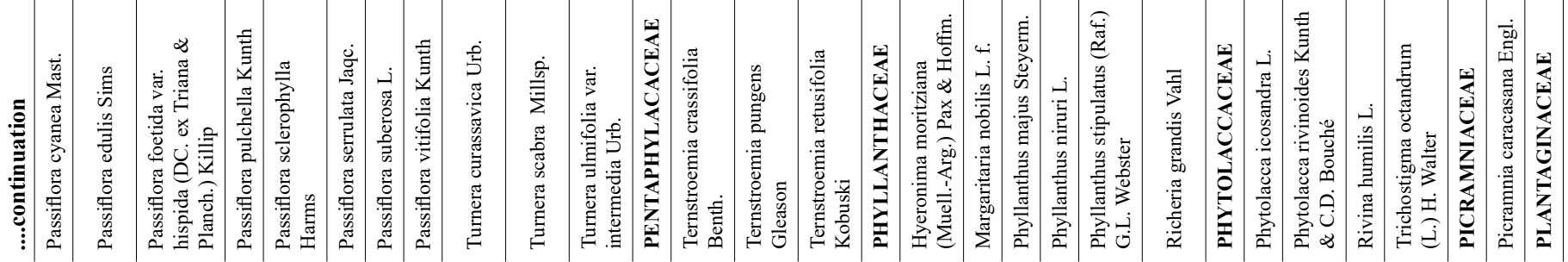




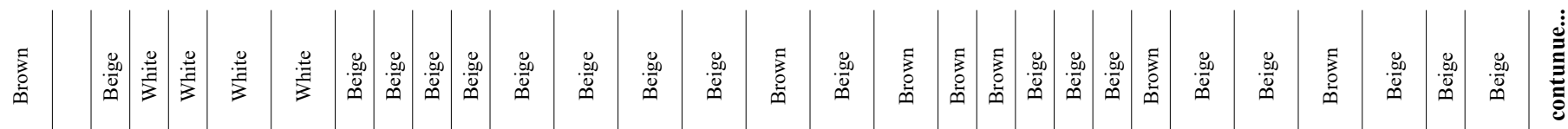

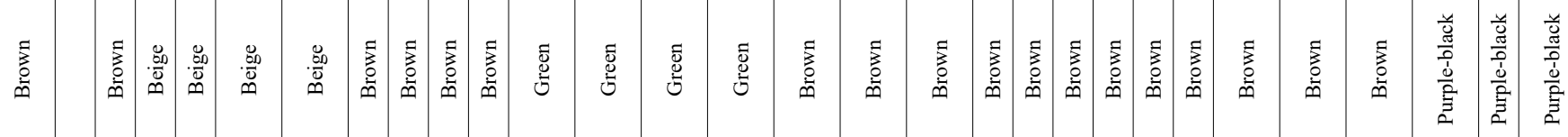

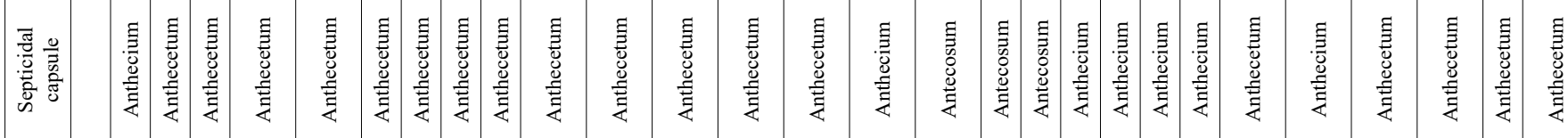

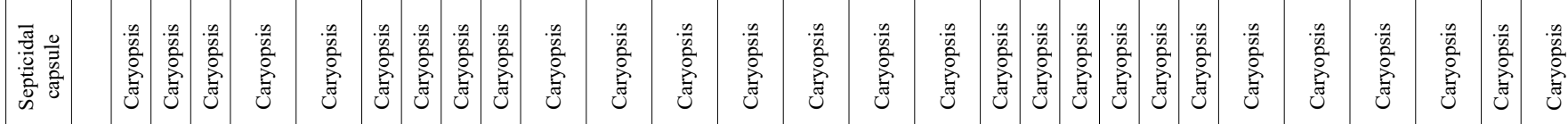

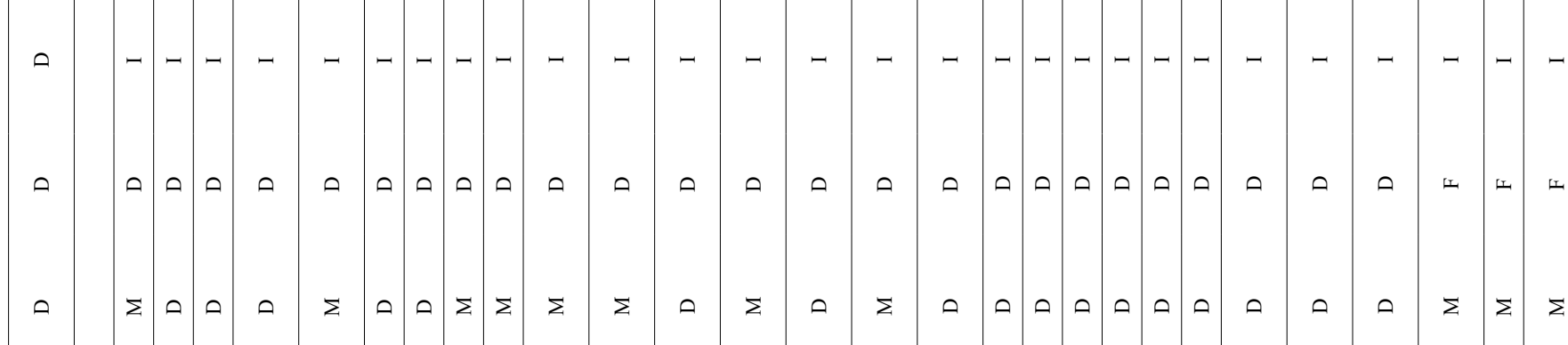

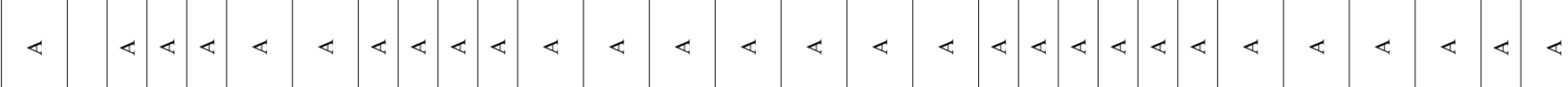

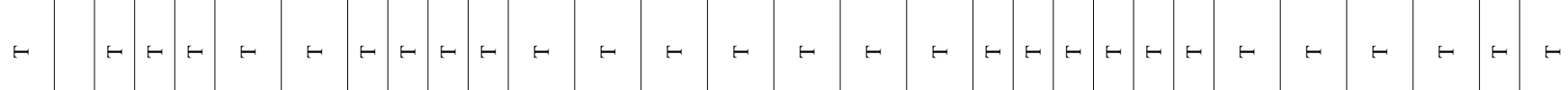

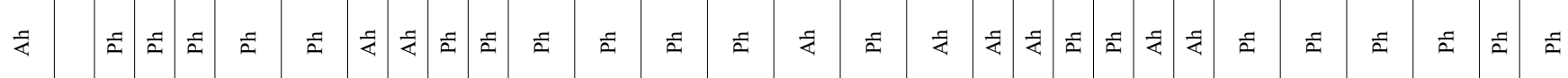

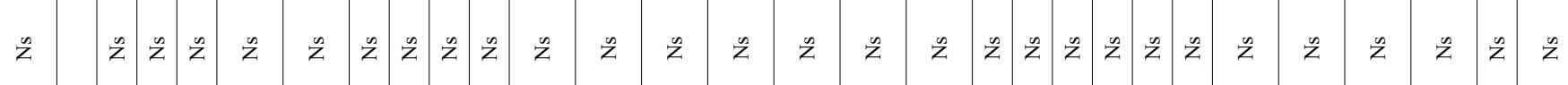

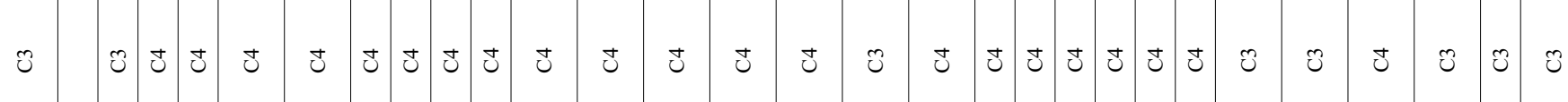

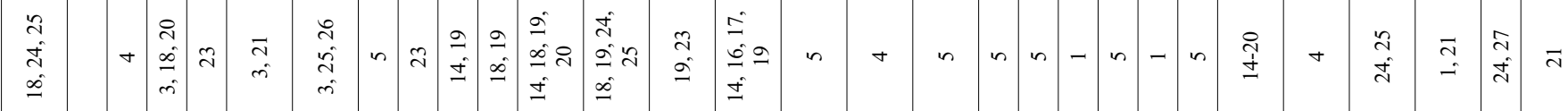

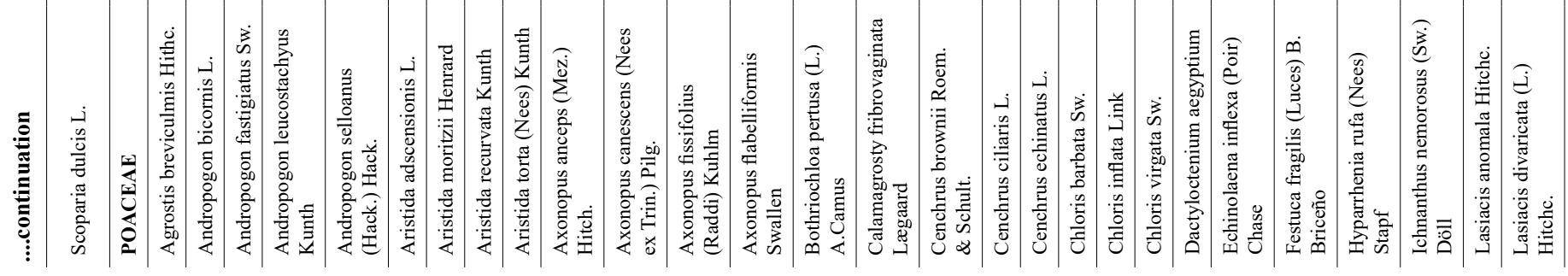




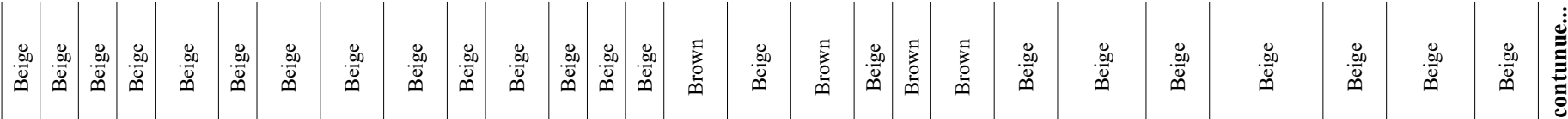

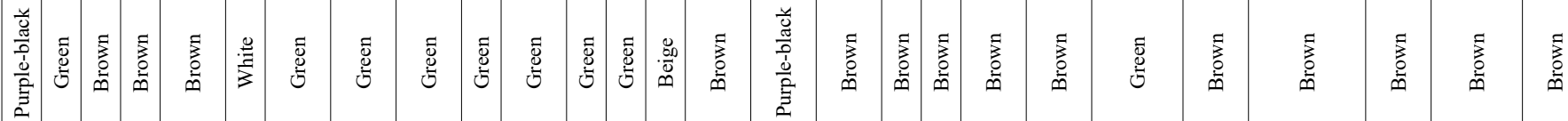

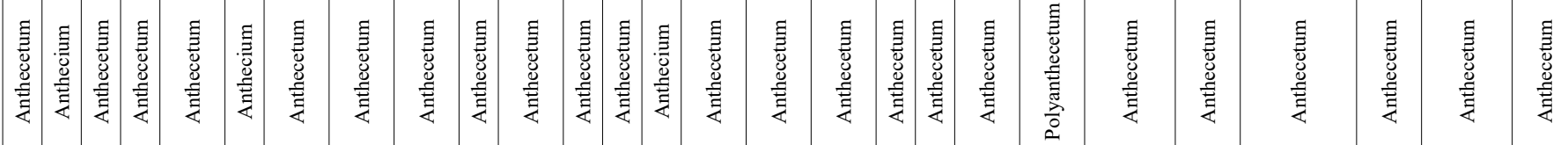

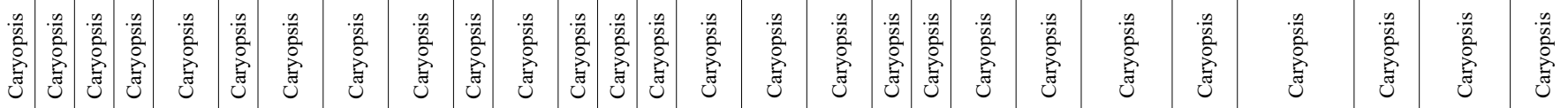
上

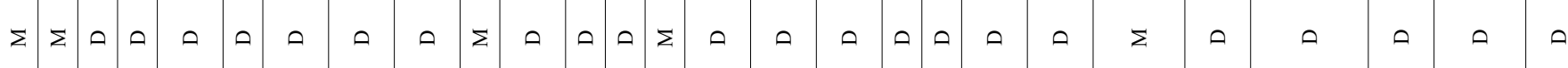

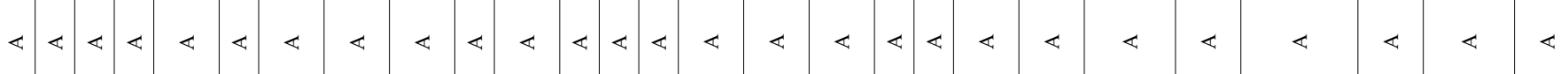

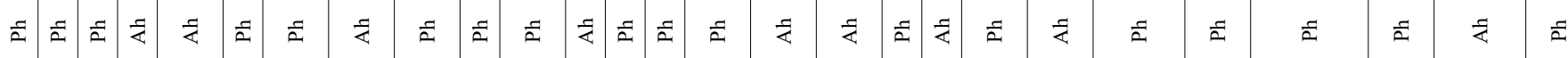

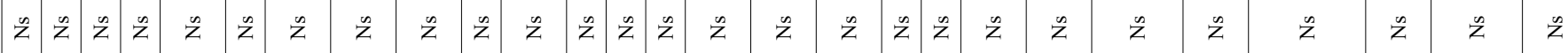

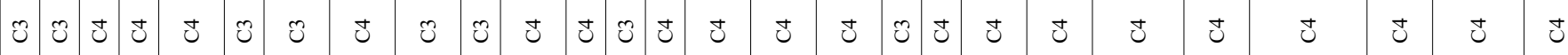

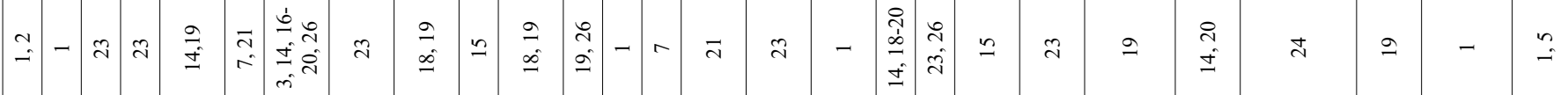

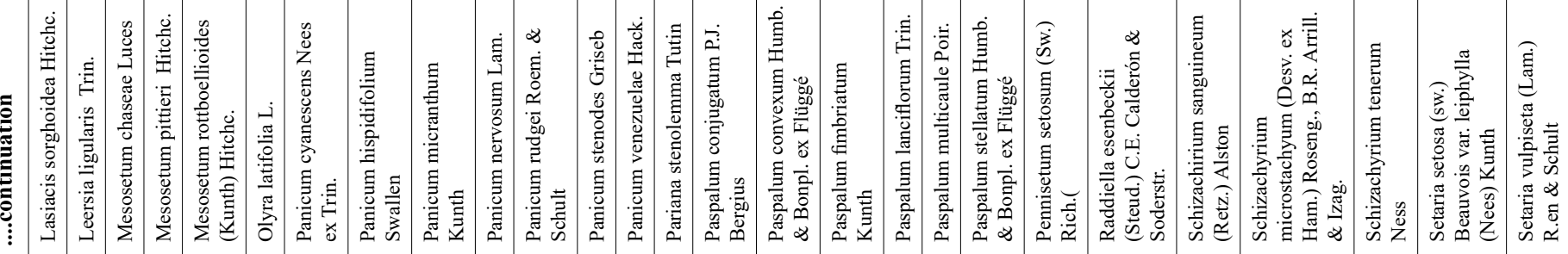




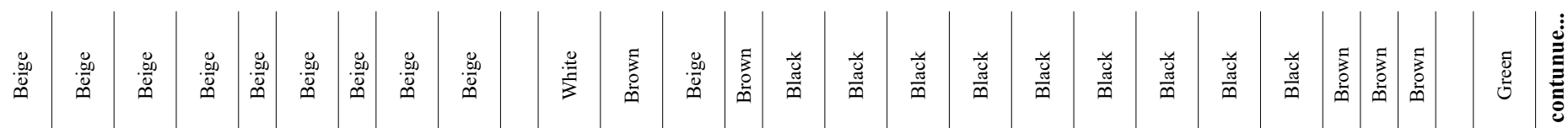

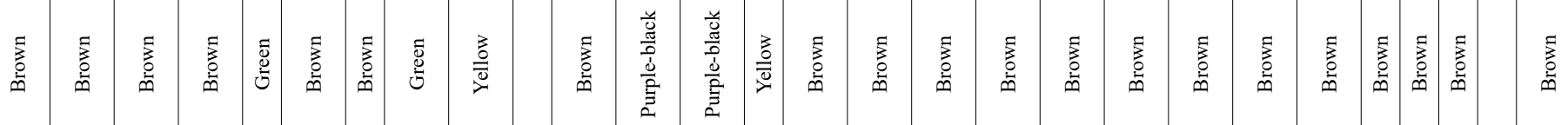

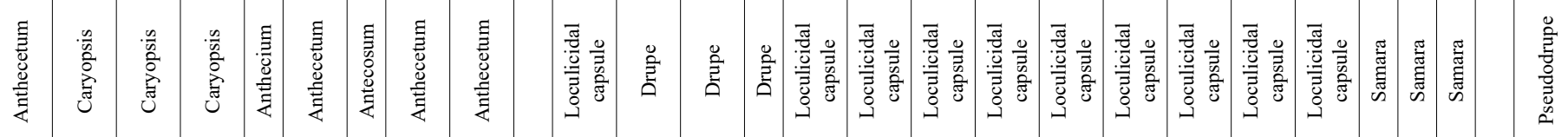

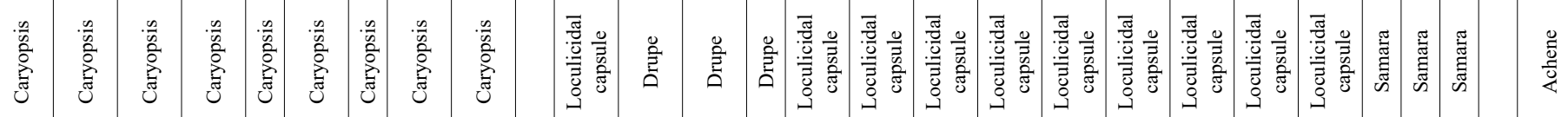

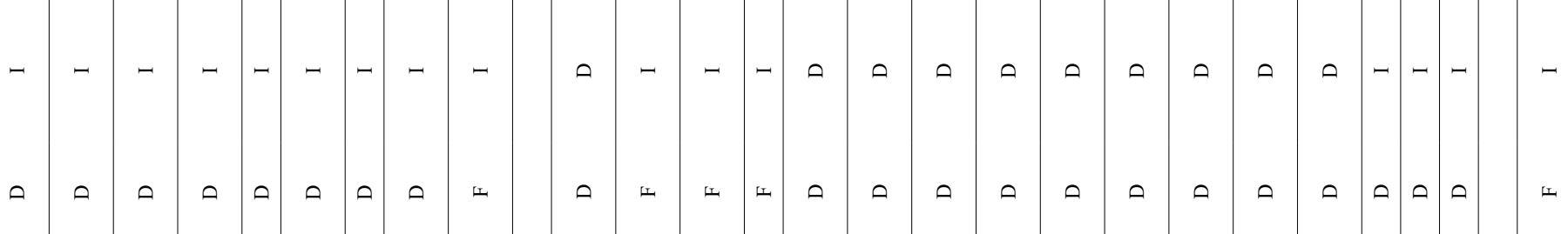

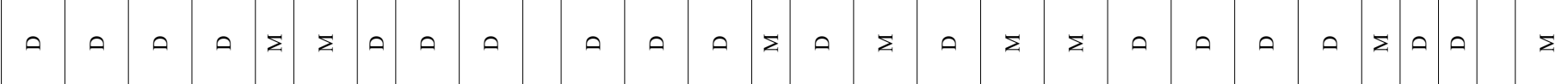

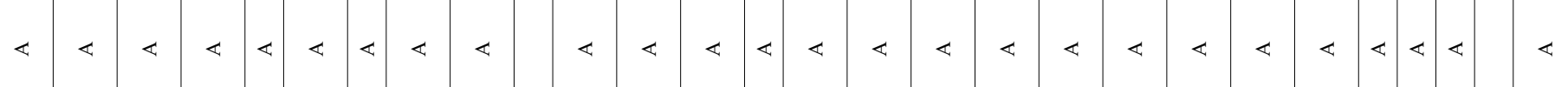

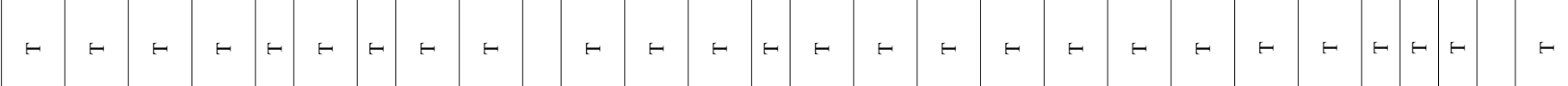

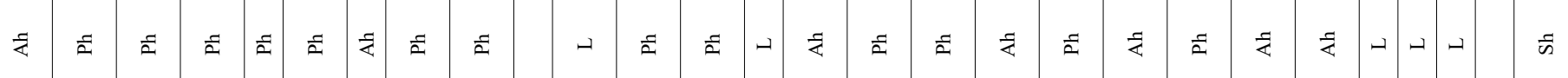

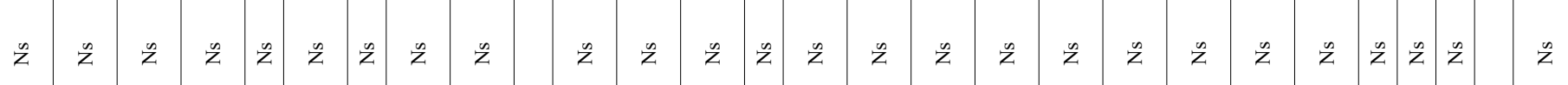

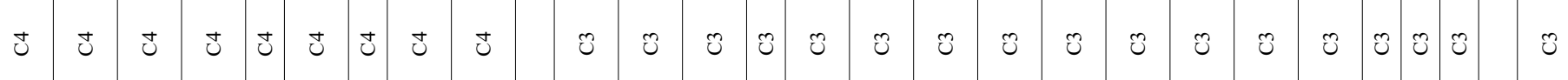

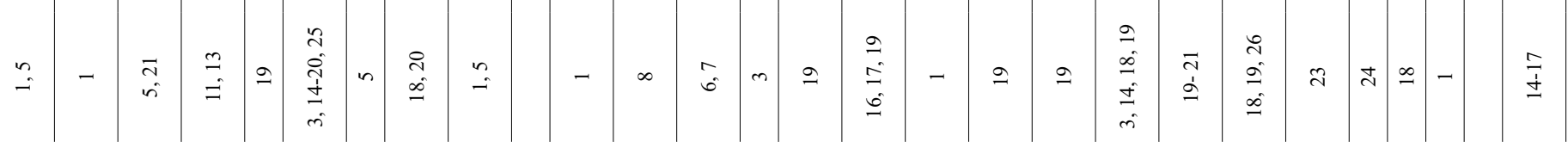

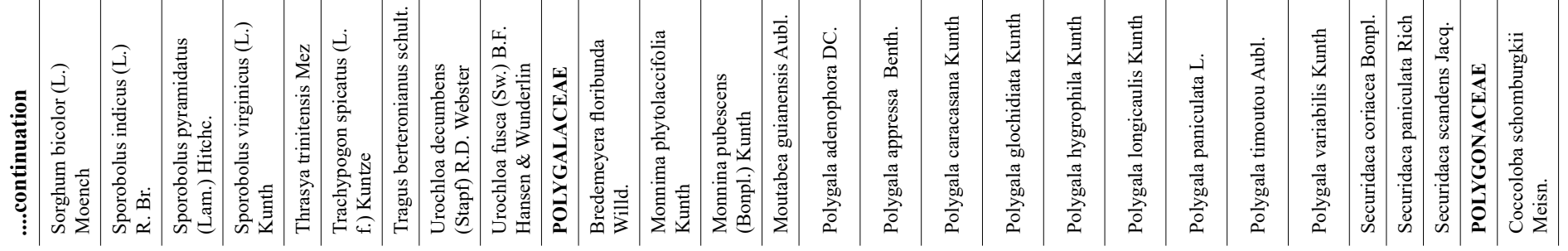


Ramírez, N. et al.

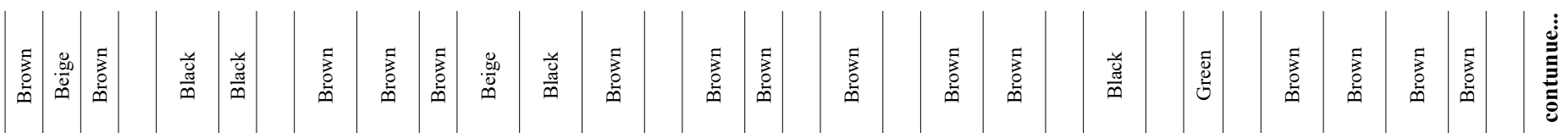

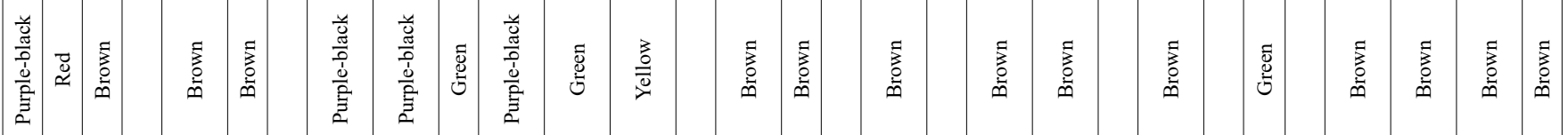

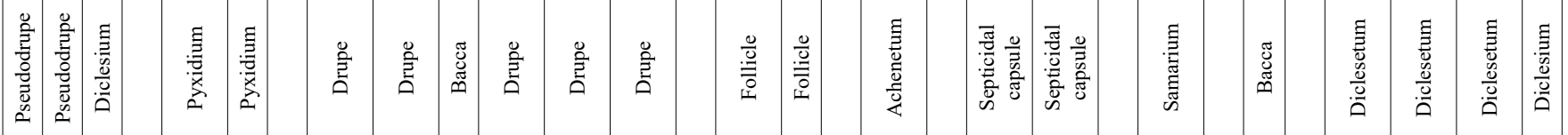

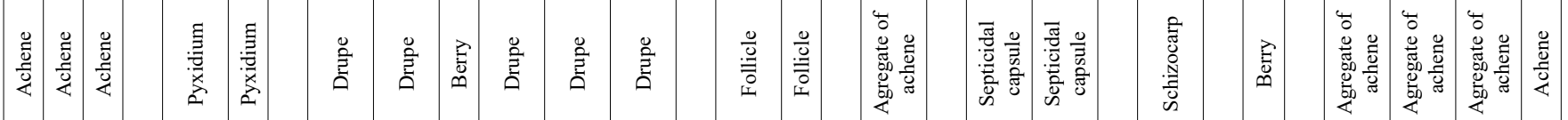

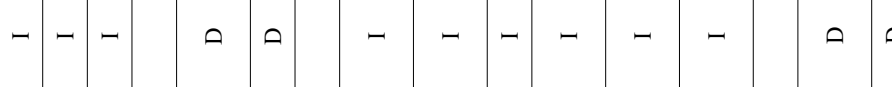

ш ш

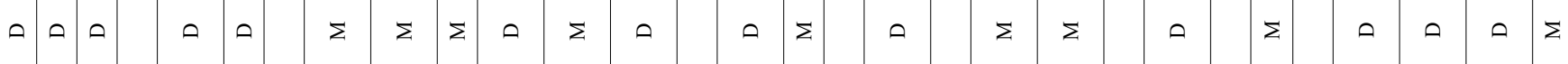

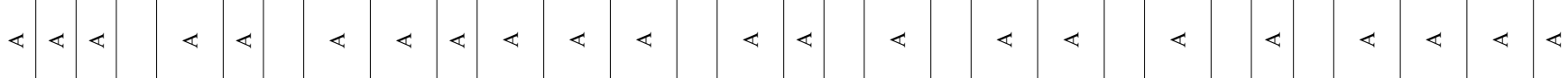

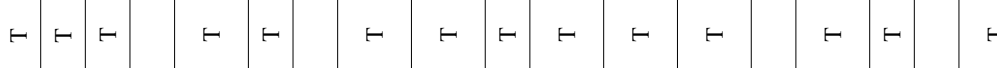

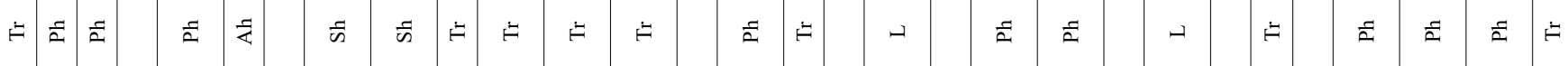

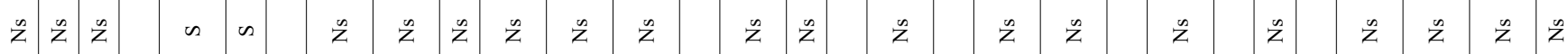

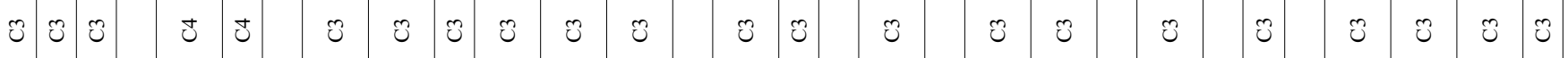

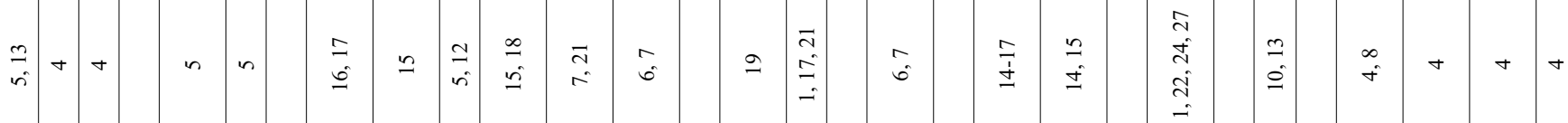

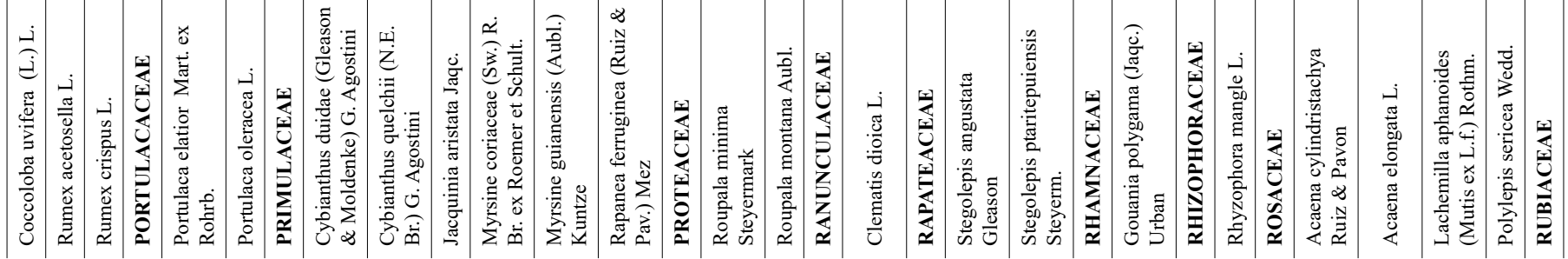




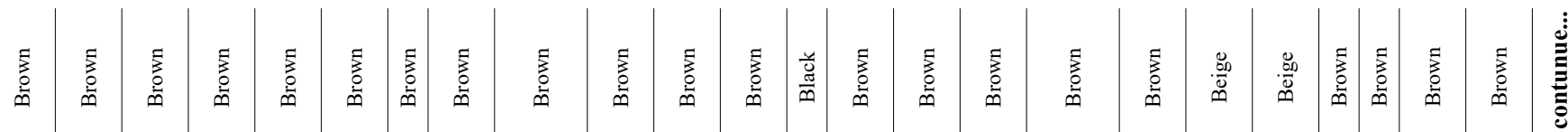

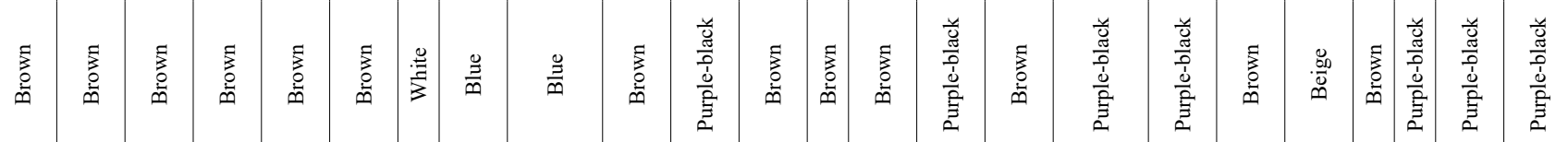

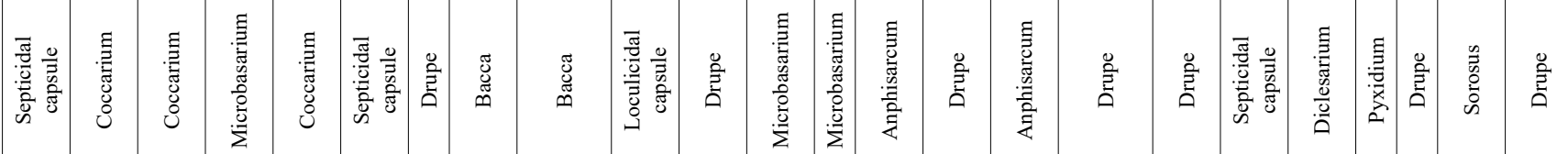

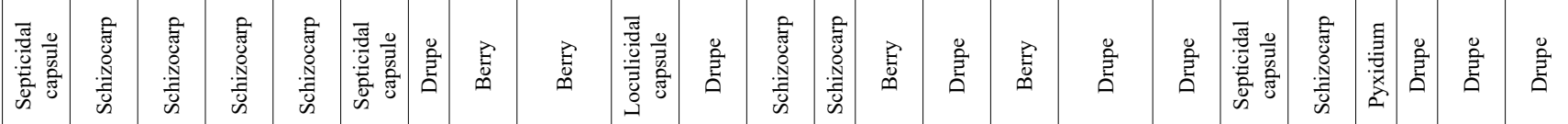
ค ○

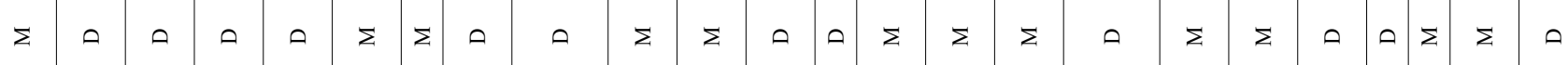

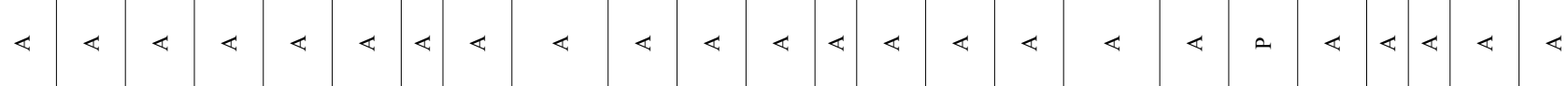

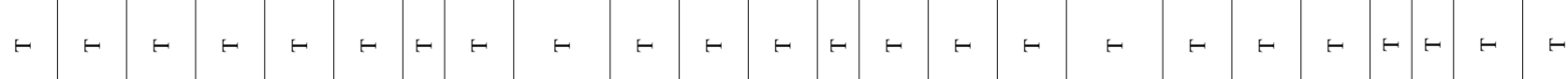

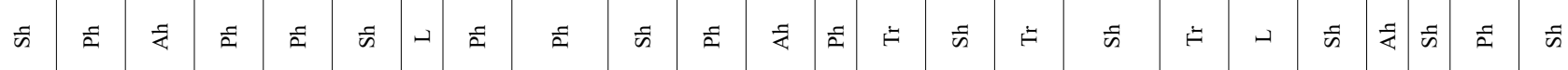

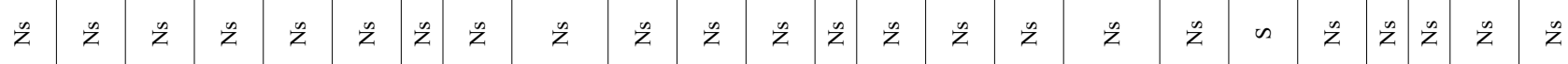

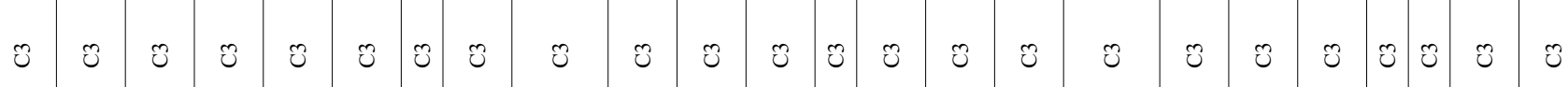

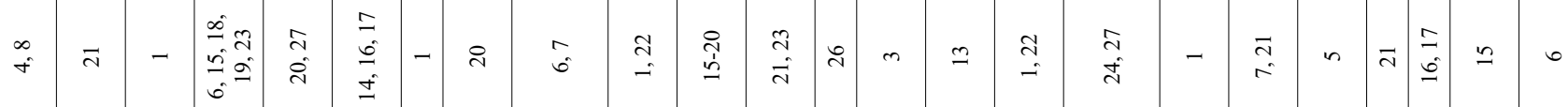

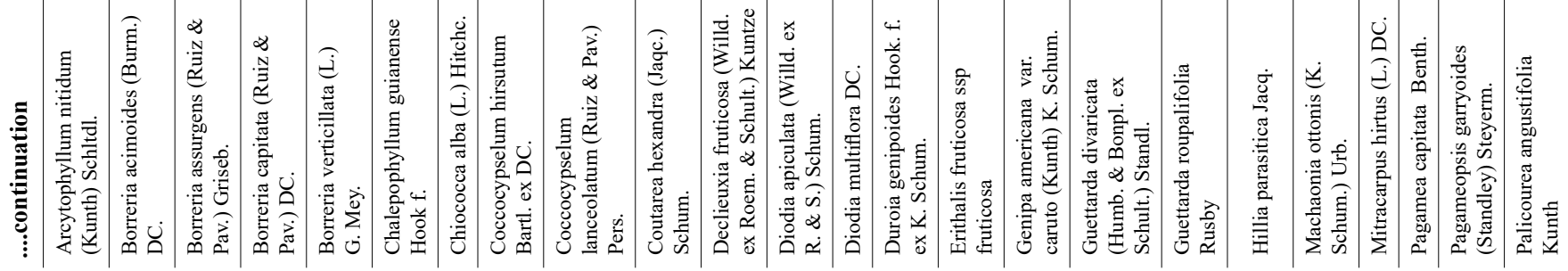


Ramírez, N. et al.

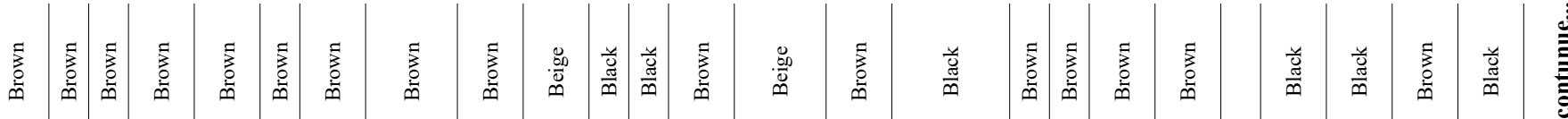

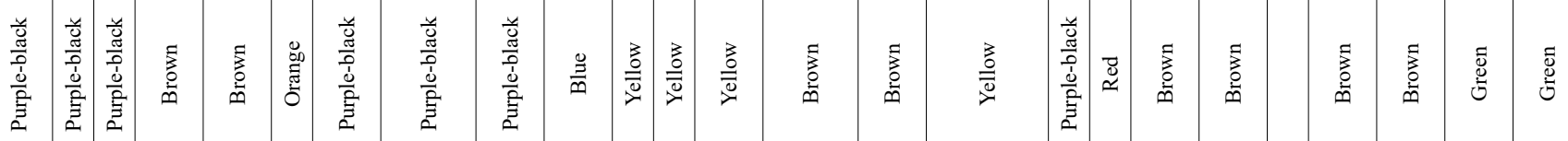

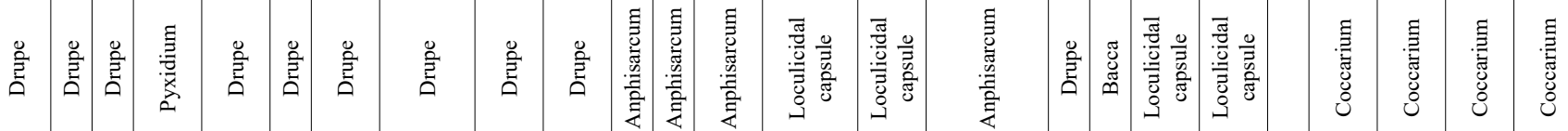

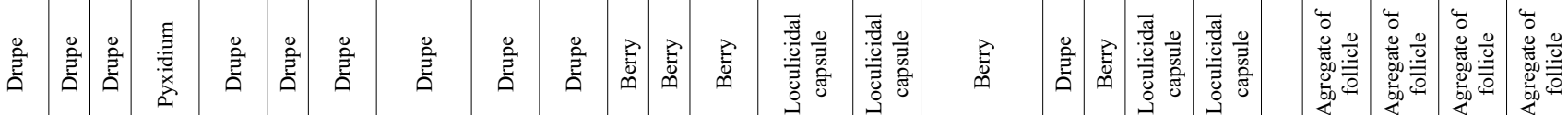

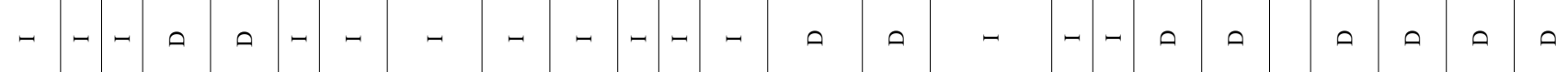
山上 出 D

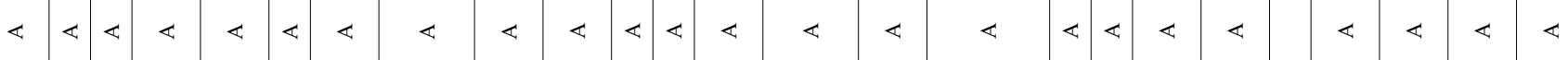

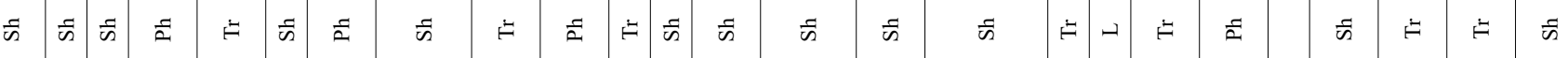

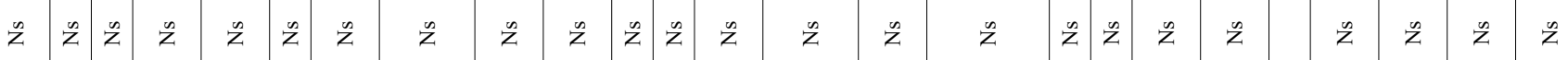

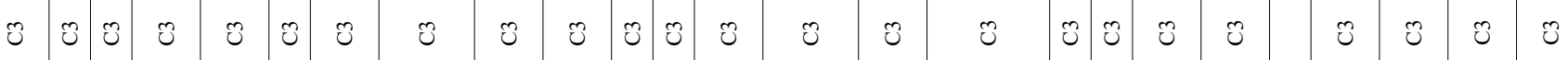

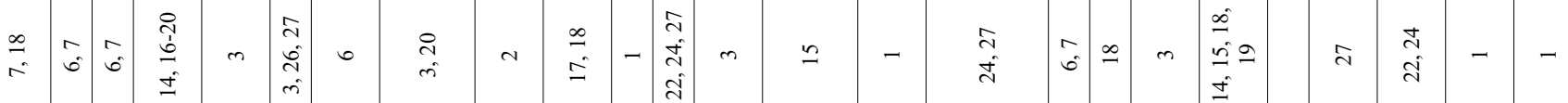

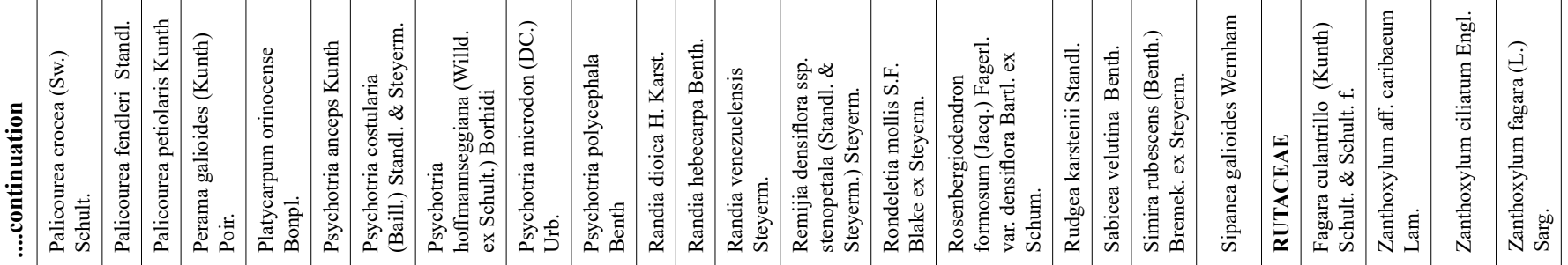




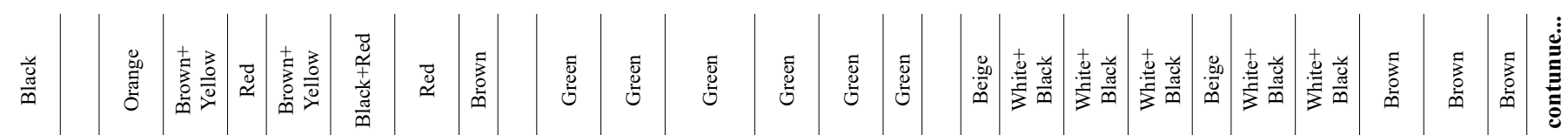

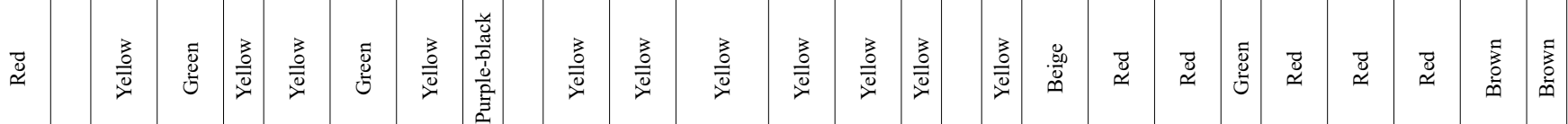

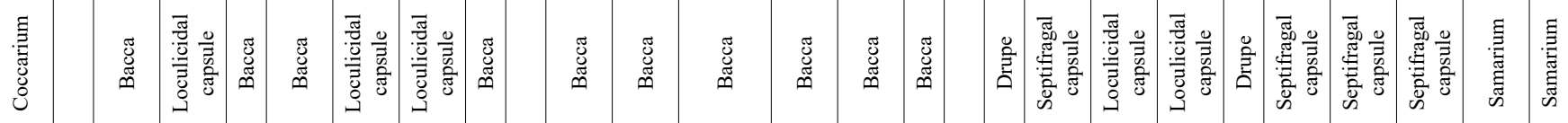

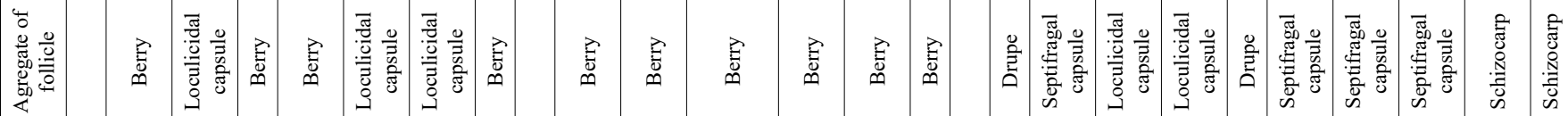

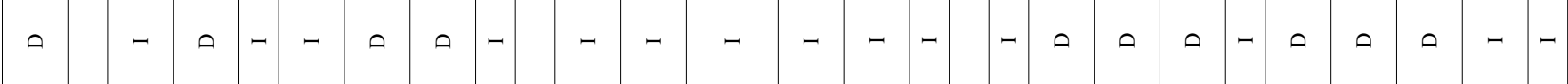
上江

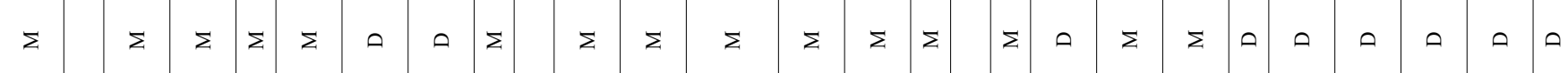

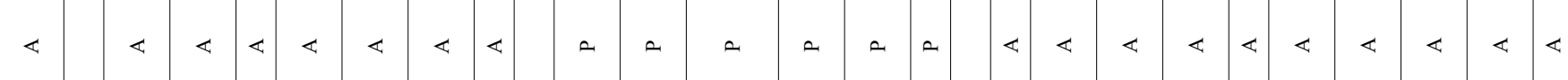

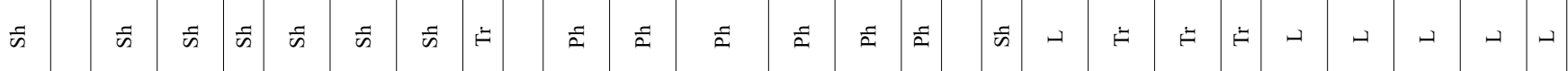

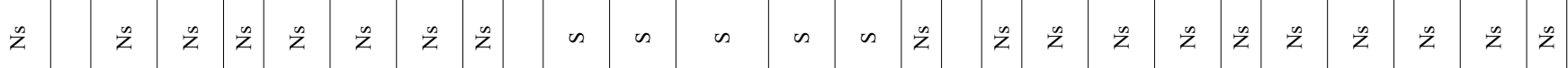

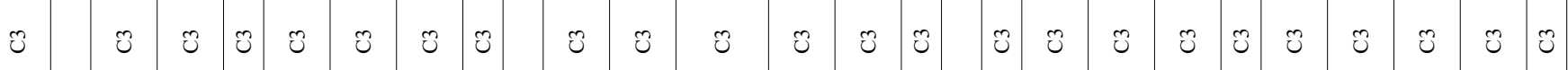

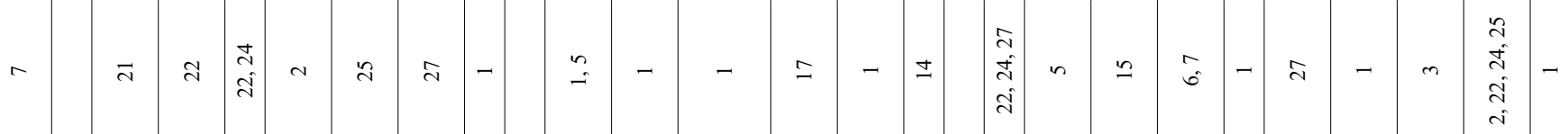

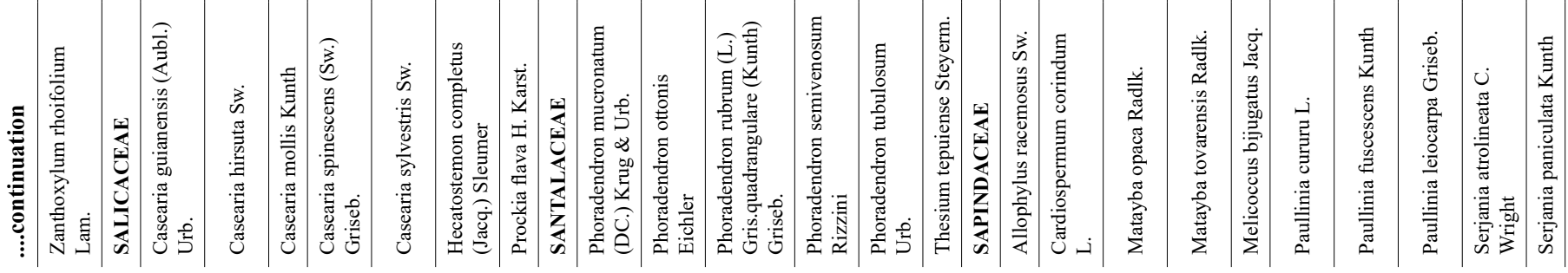


Ramírez, N. et al.

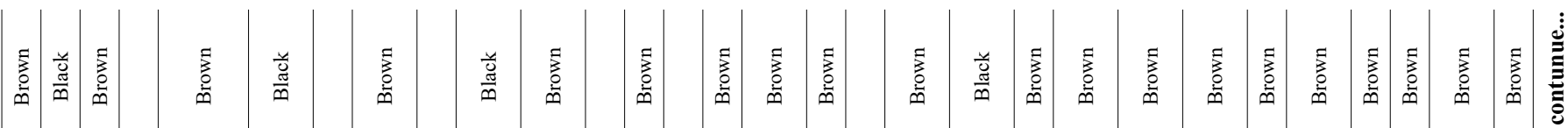

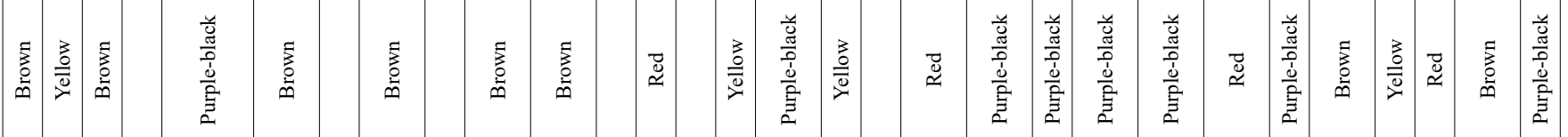

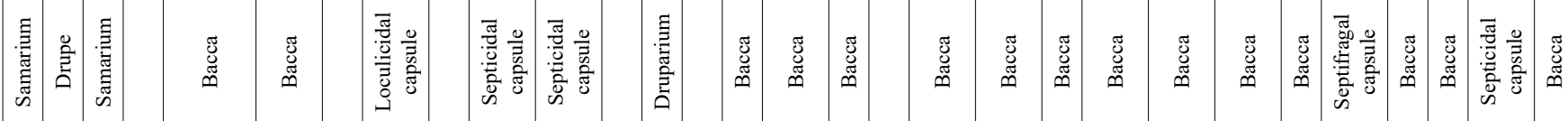

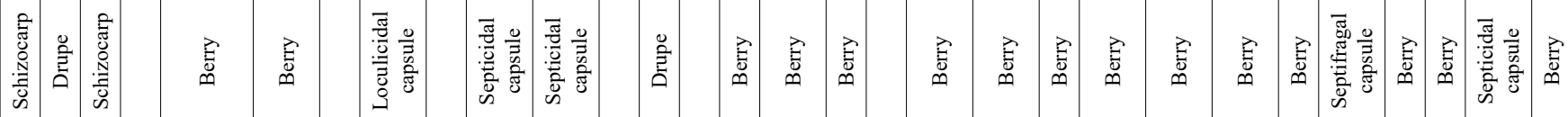

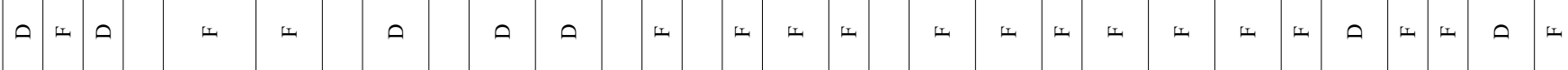

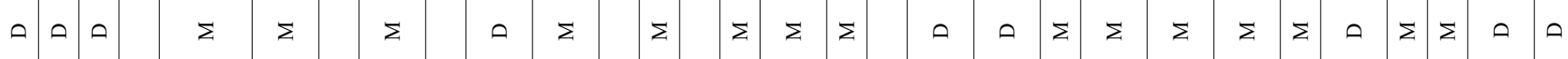

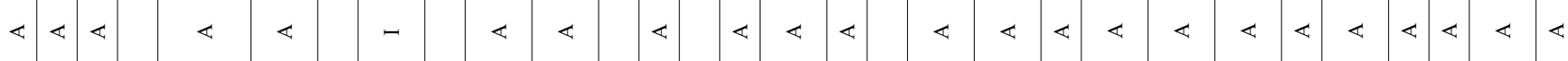
h H H

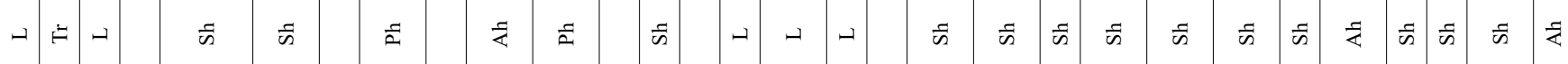

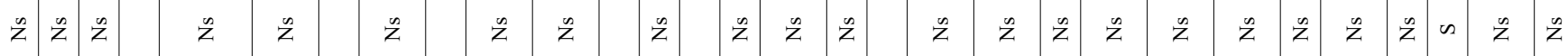

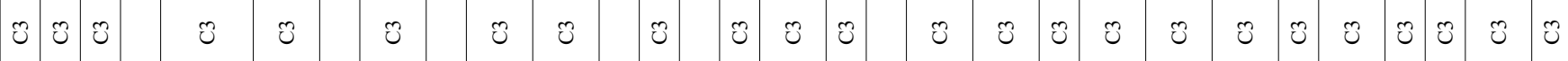

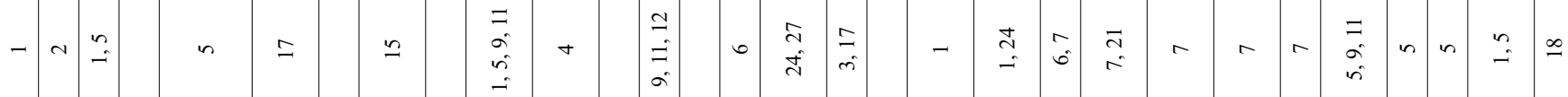

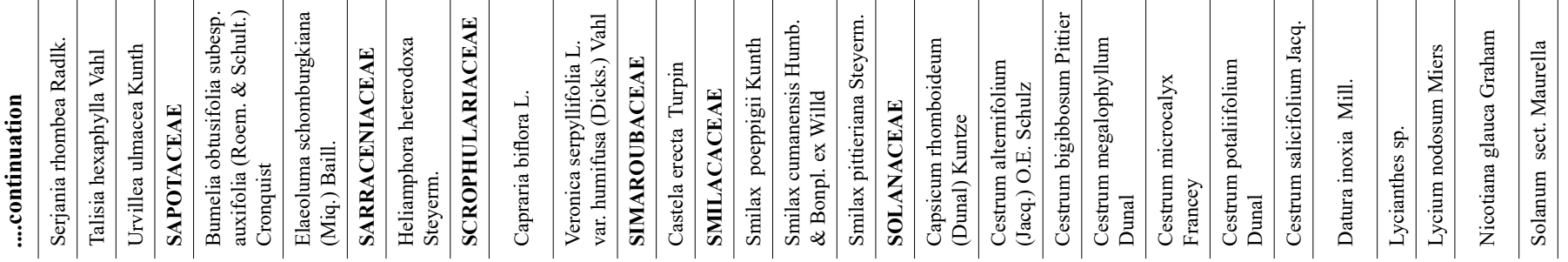




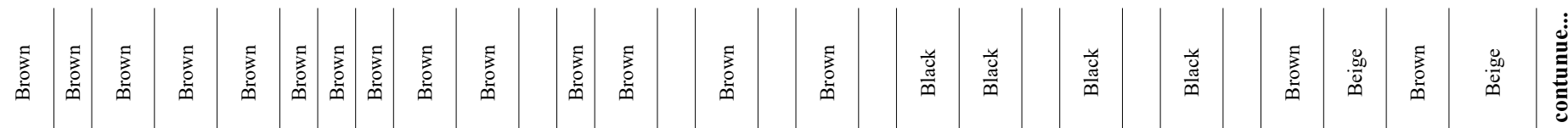

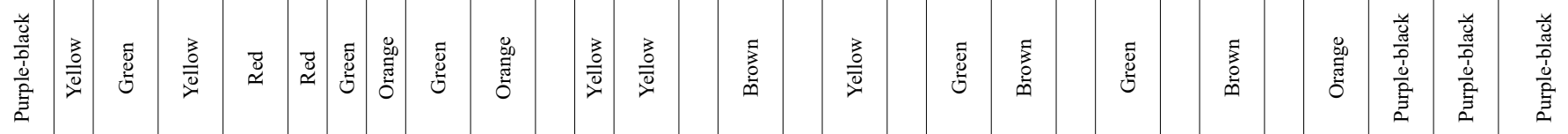

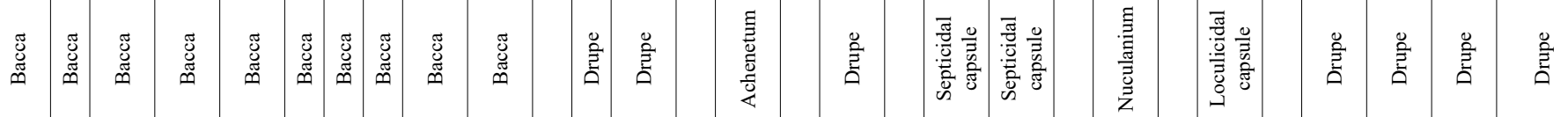

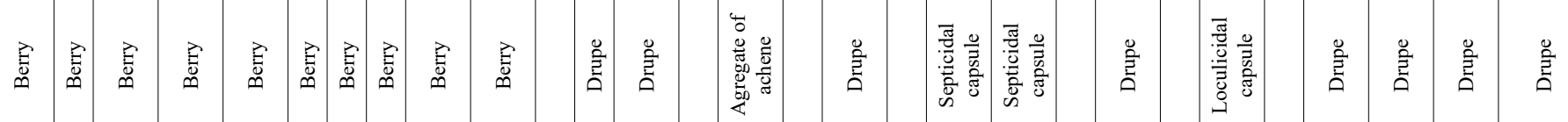

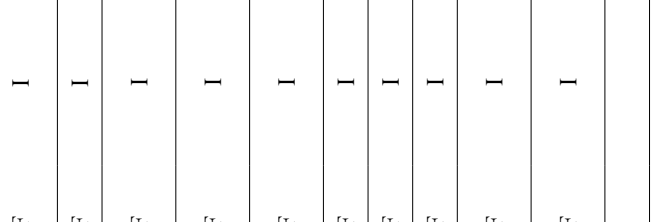

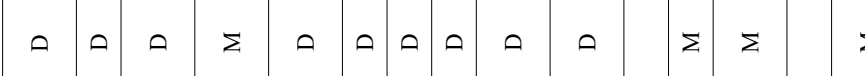

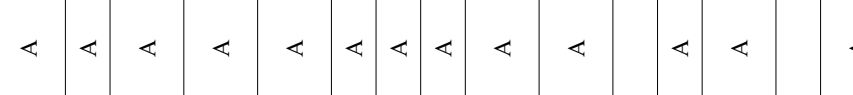

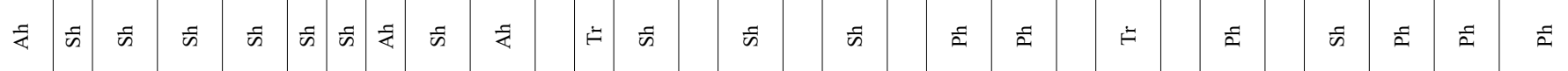

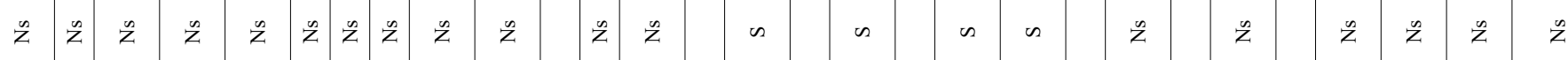

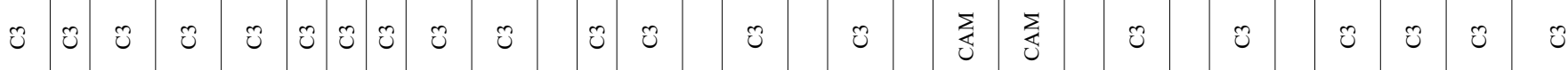

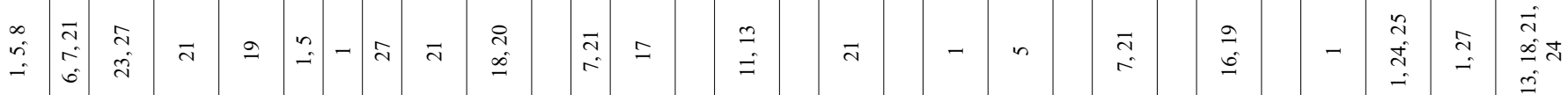

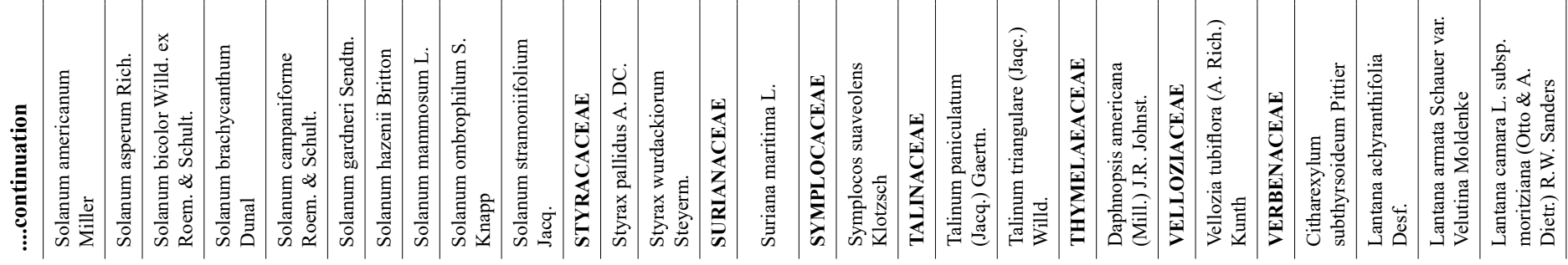


Ramírez, N. et al.

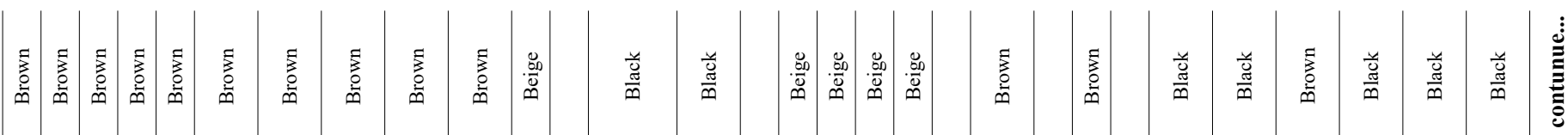

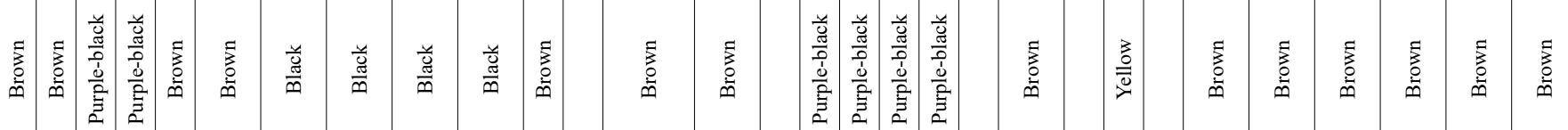

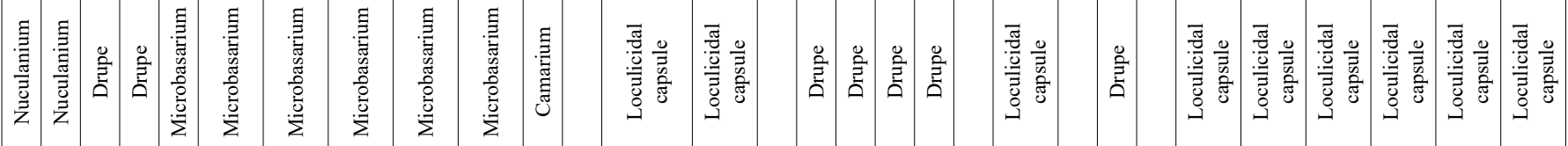

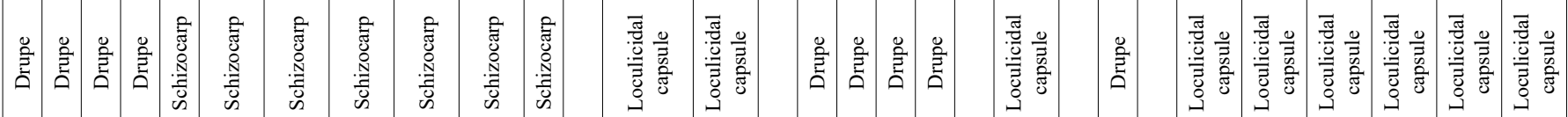

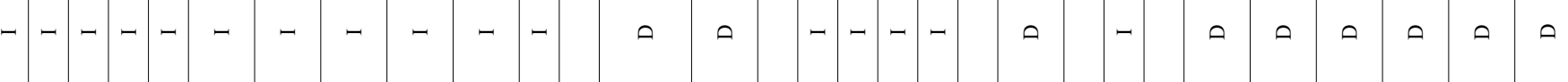
ш ш ш ш

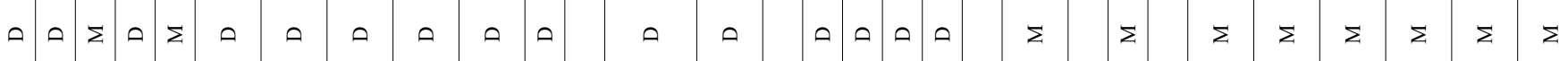

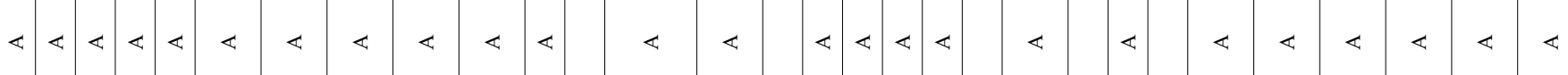

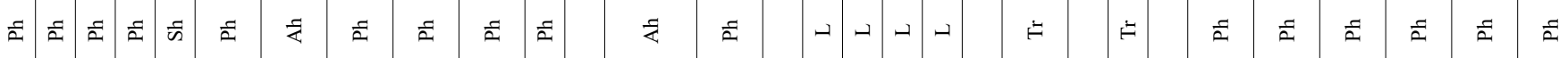

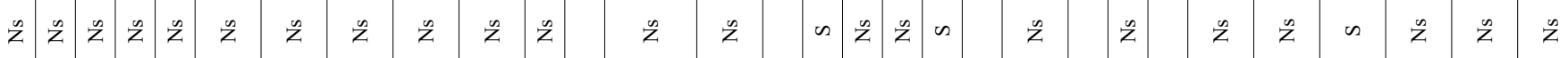

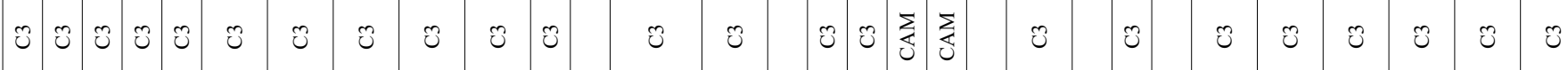

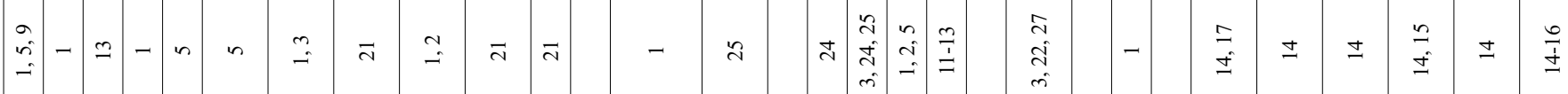

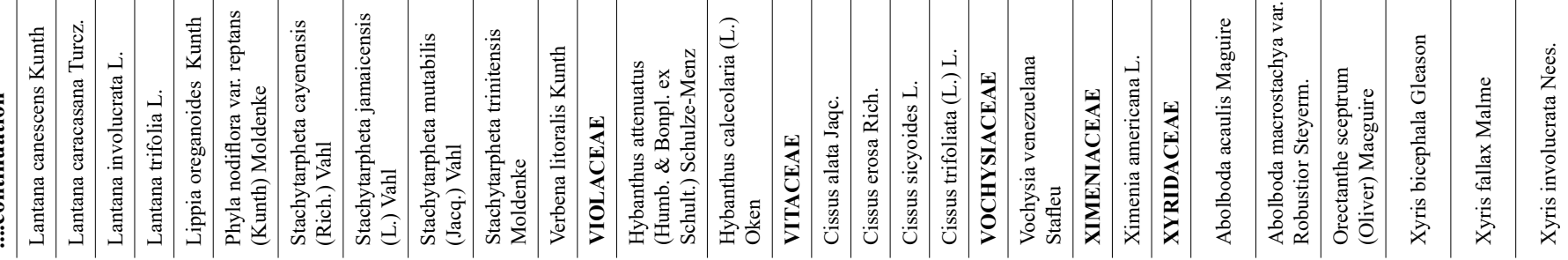


Fruits, seeds, colors, and functional groups

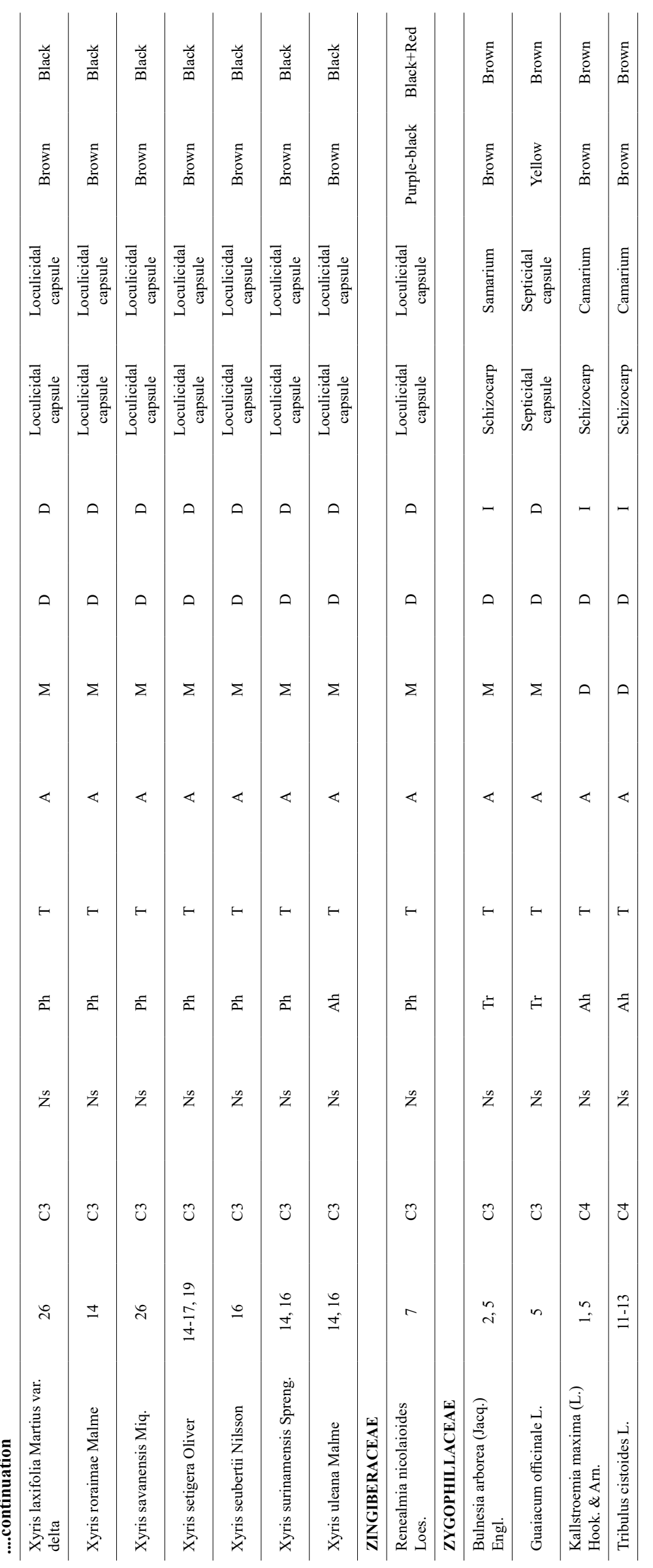


Ramírez, N. et al.

${ }^{1}$ Localities

$1=$ Secondary dry forest, Caracas Valley. $10^{\circ} 29^{\prime} \mathrm{N} ; 66^{\circ} 33^{\prime} \mathrm{W}$

$2=$ Riparian dry forest, Tuy Valley, Cua, Miranda State. $10^{\circ} 09^{\prime} \mathrm{N} ; 66^{\circ} 53^{\prime} \mathrm{W}$

$3=$ Riparian wet forest, Cataniapo River. Amazonas State. $5^{\circ} 36^{\prime} \mathrm{N} ; 67^{\circ} 6^{\prime} \mathrm{W}$

4= Páramo, Andean High Mountain, La Culata National Park. Merida State. $8^{\circ} 03^{\prime} \mathrm{N} ; 70^{\circ} 49^{\prime} \mathrm{W}$

$5=$ Xerophytic shrubland, Central Coastal Zone. Vargas State. $10^{\circ} 36^{\prime} \mathrm{N} ; 67^{\circ} 2^{\prime} \mathrm{W}$

$6=$ Cloud forest, Coastal mountain range, Miranda State. $10^{\circ} 20^{\prime} \mathrm{N} ; 66^{\circ} 55^{\prime} \mathrm{W}$

$7=$ Cloud forest, Coastal mountain range, Henri Pittier National Park. Aragua State. $10^{\circ} 21^{\prime} \mathrm{N} ; 67^{\circ} 36^{\prime} \mathrm{W}$

8= Sub-Páramo, High mountain shrubland, Pico Naiguatá, El Ávila National Park. Capital District. 10 $32^{\prime} \mathrm{N} ; 66^{\circ} 47^{\prime} \mathrm{W}$

9= Littoral Meadow, Coastal Plain of Paraguaná. Falcón State. $11^{\circ} 50^{\prime} \mathrm{N} ; 69^{\circ} 48^{\prime} \mathrm{W}$

$10=$ Mangrove, Coastal Plain of Paraguaná. Falcon State. $11^{\circ} 40^{\prime} \mathrm{N} ; 69^{\circ} 49^{\prime} \mathrm{W}$

$11=$ Psamophilous Meadow, Coastal Plain of Paraguaná. Falcón State. $11^{\circ} 40^{\prime} \mathrm{N} ; 69^{\circ} 49^{\prime} \mathrm{W}$

$12=$ Xerophytic shrubland, Coastal Plain of Paraguaná. Falcón State. $11^{\circ} 40^{\prime} \mathrm{N} ; 69^{\circ} 49^{\prime} \mathrm{W}$

$13=$ Littoral Shrubland, Atolon, Morrocoy National Park. Falcon State. $10^{\circ} 58^{\prime} \mathrm{N} ; 68^{\circ} 15^{\prime} \mathrm{W}$

14= Broad-leaved meadow, Gran Sabana Plateau, Canaima National Park. Bolívar State. $5^{\circ} 38^{\prime} \mathrm{N} ; 61^{\circ} 22^{\prime} \mathrm{W}$

15= Mesotermic shruland (Jardin), Gran Sabana Plateau, Canaima National Park. Bolívar State. $5^{\circ} 38^{\prime} \mathrm{N} ; 61^{\circ} 41^{\prime} \mathrm{W}$

16= Mesotermic shruland (Liworiwo), Gran Sabana Plateau, Canaima National Park. Bolívar State. $5^{\circ} 36^{\prime} \mathrm{N} ; 61^{\circ} 29^{\prime} \mathrm{W}$

$17=$ Mesotermic shruland (Mareman), Gran Sabana Plateau, Canaima National Park. Bolívar State. $5^{\circ} 44^{\prime} \mathrm{N} ; 61^{\circ} 24^{\prime} \mathrm{W}$

$18=$ Secondary bushland, Gran Sabana Plateau, Canaima National Park. Bolívar State. $5^{\circ} 40^{\prime} \mathrm{N} ; 61^{\circ} 32^{\prime} \mathrm{W}$

$19=$ Savanna grassland, Gran Sabana Plateau, Canaima National Park. Bolívar State. $5^{\circ} 42^{\prime} \mathrm{N} ; 61^{\circ} 31^{\prime} \mathrm{W}$

$20=$ Secondary savanna, Fallow, Gran Sabana Plateau, Canaima National Park. Bolívar State. $5^{\circ} 40^{\prime} \mathrm{N} ; 61^{\circ} 32^{\prime} \mathrm{W}$

$21=$ Dwarf cloud forest, Insular montane forest, Cerro Copey National Park. Nueva Esparta State. $10^{\circ} 59^{\prime} \mathrm{N} ; 63^{\circ} 54^{\prime} \mathrm{W}$

$22=$ Dry forest, Venezuelan Central Plain, Estacion Biologica de los Llanos. Guárico State. $8^{\circ} 56^{\prime} \mathrm{N} ; 67^{\circ} 25^{\prime} \mathrm{W}$

$23=$ Disturbed grassland, Venezuelan Central Plain, Estacion Biologica de los Llanos. Guárico State. $8^{\circ} 56^{\prime} \mathrm{N} ; 67^{\circ} 25^{\prime} \mathrm{W}$

24= Ecotone Forest-Savanna, Venezuelan Central Plain, Estacion Biologica de los Llanos. Guárico State. $8^{\circ} 56^{\prime} \mathrm{N} ; 67^{\circ} 25^{\prime} \mathrm{W}$

$25=$ Savanna with shrubs, Venezuelan Central Plain, Estacion Biologica de los Llanos. Guárico State. $8^{\circ} 56^{\prime} \mathrm{N} ; 67^{\circ} 25^{\prime} \mathrm{W}$

26= Palm swamp, Venezuelan Central Plain, Morichal Largo. Guárico State. $8^{\circ} 56^{\prime} \mathrm{N} ; 67^{\circ} 25^{\prime} \mathrm{W}$

$27=$ Galery forest, Venezuelan Central Plain, Orituco River. Guárico State. $9^{\circ} 47^{\prime} \mathrm{N} ; 67^{\circ} 25^{\prime} \mathrm{W}$

$28=$ Paramo, San José de Sur, Merida State.

$29=$ Dry forest, Aguas Termales Las Trincheras, Carabobo State. $10^{\circ} 18 \mathrm{~N} ; 68^{\circ} 04^{\prime} \mathrm{W}$

$30=$ Dry forest, Mision Nuestra Sra. del Carmen, Yaracuy State. $10^{\circ} 20^{\prime} \mathrm{N} ; 68^{\circ} 41 \mathrm{~W}$

$31=$ Xerophytic shrubland, Near San Juan de Lagunillas, Merida State. $8^{\circ} 30^{\prime} \mathrm{N} ; 71^{\circ} 21^{\prime} \mathrm{W}$

$32=$ Xerophytic shrubland, Mesa de Esnujaque, Trujillo State. $9^{\circ} 03^{\prime} \mathrm{N} ; 70^{\circ} 42^{\prime} \mathrm{W}$

$33=$ Experimental Station, Barrancas, Barinas State. $8^{\circ} 46^{\prime} \mathrm{N}, 70^{\circ} 25^{\prime} \mathrm{W}$

$34=$ Dry forest, flooded plain of the Mene river, Zulia State. $10^{\circ} 27^{\prime} \mathrm{N} ; 71^{\circ} 27^{\prime} \mathrm{W}$

35=Mesotermic shruland (Kama fall), Gran Sabana Plateau, Canaima National Park. Bolívar State.

36= Montane Forest, Avila National Park, Capital District.

$37=$ Dry premontane forest, Los Caracas, Distrito Federal, Estado Vargas. $10^{\circ} 37^{\prime} \mathrm{N} ; 66^{\circ} 34^{\prime \prime} \mathrm{W}$

$38=$ Rain forest, Imataca Reserve, Bolívar State. $8^{\circ} 03^{\prime} \mathrm{N} ; 61^{\circ} 39^{\prime} \mathrm{W}$

$39=$ Rain forest, near El Dorado, Bolívar State. $6^{\circ} 43^{\prime} \mathrm{N} ; 61^{\circ} 37^{\prime} \mathrm{W}$

40= Municipio Manrique, Road to La Sierra, Cojedes State.

41 = Municipio Romulo Gallegos, East to Las Vegas, Cojedes State.

42 = Disturbed area, Guanare-Mesa Cavacas road, Portuguesa State.

43 = Páramo, Andean High Mountain, El Zumbador, Tachira State

44 = Salazar town, To Chururú, Tachira State

45 = Road edge, Dabajuro-Maracaibo, Falcón State.

46 = Stream border, National Park, Cuevas de la quebrada, El Toro, Falcón State,

$47=$ Disturbed area, Maracay, Aragua State.

48 = Avocado plantation, Palo Negro, Aragua State.

$49=$ Road side Merida-Jaji, Las Correras, Merida State.

$50=$ Road Barinas-Santo Domingo, Barinas State.

${ }^{2}$ Succullence: $\mathrm{S}=$ Succulent, Ns = No succulent

${ }^{3}$ Life form: $\mathrm{Tr}=$ Trees, $\mathrm{Sh}=$ Shrubs, $\mathrm{L}=$ Lianas, $\mathrm{Ph}=$ Perennial herbs, $\mathrm{Ah}=$ Annual herbs

${ }^{4}$ Epiphytism: $\mathrm{T}=$ Terrestrials, $\mathrm{E}=$ Epiphytes

${ }^{5}$ Nutritional relation: $\mathrm{A}=$ Autotropics, $\mathrm{I}=$ Insectivores, $\mathrm{P}=$ Parasitics

${ }^{6}$ Successional stage: $\mathrm{M}=$ Mature, $\mathrm{D}=$ Disturbed

${ }^{7}$ Fruit texture: $\mathrm{F}=$ Fleshy, $\mathrm{D}=$ Dry

${ }^{8}$ Fruit dehiscence: $\mathrm{D}=$ Dehiscent, $\mathrm{I}=$ Indehiscent 


\section{Author Contributions}

Nelson Ramírez: Contribution in the concept of the study; data collection; data analysis and interpretation; manuscript preparation; contribution to critical revision, adding intellectual content.

Yeni Barrios: Contribution to data collection; manuscript preparation; contribution to critical revision, adding intellectual content; data analysis and interpretation.

Herbert Briceño: Contribution to data collection; data analysis and interpretation; manuscript preparation.

\section{Conflicts of Interest}

The authors declare that they have no conflict of interest related to the publication of this manuscript.

\section{Ethics}

We declare that the procedures used in this study have no ethic conflicts.

\section{References}

ALMEIDA-NETO, M., CAMPASSI, F., GALETTI, M., JORDANO, P. \& OLIVEIRA-FILHO, A. 2008. Vertebrate dispersal syndromes along the Atlantic forest: broad-scale patterns and macroecological correlates. Global Ecol. Biogeogr. 17: 503-513.

AMARAL, A.G., MUNHOZ, C.B.R., EUGÊNIO, C.U.O. \& FELFILI, J.M. 2013. Vascular flora in dry-shrub and wet grassland Cerrado seven-years after a fire, Federal district, Brazil. Check List 9: 487-503.

APG IV. 2016. An update of the Angiosperm Phylogeny Group classification for the orders and families of flowering plants: APG IV. Bot. J. Linn. Soc. 181: 1-20.

ARBELÁEZ, M.V. \& PARRADO-ROSSELLI, A. 2005. Seed dispersal modes of the sandstone plateau vegetation of the middle Caquetá River region, Colombian Amazonia. Biotropica 37: 64-72.

ASSIS, A.P.A., THOMPSON, J.N., SANTANA, P.C., JORDANO, P., BASCOMPTE, J. \& GUIMARÃES JR. P.R. 2020. Genetic correlations and ecological networks shape coevolving mutualisms. Ecol. Lett. https:// doi.org/10.1111/ele.13605

BATALHA, M.A. \& MARTINS, F.R. 2004. Reproductive phenology of the cerrado community in Emas National Park (central Brazil). Australian J. Bot. 52: 149-161.

BASCOMPTE, J. \& JORDANO, P.2007. Plant-Animal Mutualistic Networks: The Architecture of Biodiversity. Annu. Rev. Ecol. Evol. Syst. 38: 567-593.

BAZZAZ, F.A., CARLSON, R.W. \& HARPER, J.L. 1979. Contribution to reproductive effort by photosynthesis of flowers and fruits. Nature (Lond.) 279:554-555.

BENTOS, T. V., MESQUiTA, R., C. G. \& WiLliamson, G. B. 2008. Reproductive Phenology of Central Amazon Pioneer Trees. Trop. Conserv. Sci. 1:186-203.

BENZING, D.H. 1990. Vascular Epiphytes. Cambridge University Press, Cambridge, United Kingdom.

BERRY, P.E. 1984. Estrategias reproductivas de las plantas del Alto Paramo de Venezuela. Informe técnico. CONICIT, Caracas, Venezuela. Pp. 54.

BLÜTHGEN, N., MENZEL, F., HOVESTADT, T., FIALA, B. \& BLÜTHGEN N. 2007. Specialization, constraints and conflicting interests in mutualistic networks. Curr. Biol. 17: 1-6.

BODMER, R.E. 1989. Frugivory in Amazonian Artiodactyla: evidence for the evolution of the ruminant stomach. J. Zool. 219(3): 457-467.

BODMER, R. 1991. Strategies of Seed Dispersal and Seed Predation in Amazonian Ungulates. Biotropica 23: 255-261.
BOLMGREN, K. \& ERIKSSON, O. 2005. Fleshy fruits-origins, niche shifts, and diversification. Oikos 109: 255-272.

BOLMGREN, K. \& ERIKSSON, O. 2010. Seed mass and the evolution of fleshy fruits in angiosperms. Oikos 119: 707-718.

BOSQUE, C., RAMÍREZ, R. \& RODRÍGUEZ, D. 1995. The diet of oilbird in Venezuela. Ornit. Neotr. 6: 67-80.

BUITRÓN-JURADO, G. \& RAMÍREZ, N. 2014. Dispersal spectra, diaspore size and the importance of endozoochory in the equatorial Andean montane forests. Flora 209: 299-311.

BULHÃO, F. \& FIGUEIREDO, P.S. 2002. Fenologia de leguminosas arbóreas em uma área de cerrado marginal no nordeste do Maranhão. Rev. Brasil. 25: 361-369.

BURROWS, C.J. 1994. Fruit types and seed dispersal modes of woody plants in Ahuriri Summit Bush, Port Hills, western Banks Peninsula, and Canterbury, New Zealand. New Zealand J. Bot. 32: 169-181.

CARPENTER, R.J., READ, J. \& JAFFRÉ, T. 2003. Reproductive traits of tropical rain-forest trees in New Caledonia. J. Trop. Ecol. 19: 351-365.

CASTILLO, A. 1977. Estudio de una sección del bosque de galeria del río Orituco al sur de los Llanos de Calabozo. Tesis de Licenciatura, Facultad de Ciencias, Escuela de Biología, Universidad Central de Venezuela. Caracas.

CASTRO-LAPORTTE, M. \& RUÍZ-ZAPATA, T. 2000. Sistemas reproductivos y relación polen/óvulo en Cestrum L (Cestreae - Solanaceae). Rev. Inter. Bot. Exp. 67: 133-137.

CAZETTA, E., SCHAEFER, H.M. \& GALETTI, M. 2009. Why are fruits colorful? The relative importance of achromatic and chromatic contrasts for detection by birds. Evol. Ecol. 23: 233-244.

CHAMBERS, J.C. \& MACMAHON, J.A. 1994. A day in the life of a seed: movements and fates of seeds and their implications for natural and managed systems. Ann. Rev. Ecol. Syst.25: 263-292.

CHEN, J., FLEMING, T.H., ZHANG, L., WANG, H. \& LIU, Y. 2004. Patterns of fruits in a tropical rain forest in Xishuangbanna, SW China. Acta Oecol. 26: $157-164$.

CIPPOLLINI, M.L. \& STILES, E.W. 1992. Antifungal activity of ripe Ericaceous fruits: phenolic-acid interactions and palatability for dispersers; Biochem. Syst. Ecol. 20 501-514

COLONNELLO, G. 1980. Composicion florística, fenología y fisonomía del bosque El Pinar. Tesis Licenciatura, Facultad de Ciencias, Universidad Central de Venezuela, Caracas, Venezuela.

CORBELLI, J.M., ZURITA G.A., FILLOY, J., GALVIS, J.P., VESPA, N.I., BELLOCQ, I. 2015. Integrating taxonomic, functional and phylogenetic beta diversities: Interactive Effects with the Biome and Land Use across Taxa. PLoS ONE 10(5): e0126854. doi:10.1371/journal.pone.0126854

CORTÉS-FLORES, J., CORNEJO-TENORIO, G., URREA-GALEANO, L.A., ANDRESEN, E., GONZÁLEZ-RODRÍGUEZ, A. \& IBARRAMANRÍQUEZ, G. 2019. Phylogeny, fruit traits, and ecological correlates of fruiting phenology in a Neotropical dry forest. Oecologia 189: 159-169.

DAUN, J.K. \& DECLERCQ, D.R. 1988. Quality of yellow and dark seeds in Brassica campestris canola varieties Candle and Tobin. J. Am, Oil Chem. Soc 65: $122-126$.

DEBEAUJON, I., LÉON-KLOOSTERZIEL, K.M. \& KOORNNEEF, M. 2000. Influence of the testa on seed dormancy, germination, and longevity in Arabidopsis. Plant Physiol. 122: 403-414.

DEVINEAU, J.L. 1999. Seasonal rhythms and phenological plasticity of savanna woody species in a fallow farming system (south-west Burkina Faso). J. Trop. Ecol.15: 497-513.

DEVLAEMINCK, R., BOSSUYT, B. \& HERMY, M. 2005. Inflow of seeds through the forest edge: evidence from seed bank and vegetation patterns. Pl. Ecol. 176: 1-17.

DONATTI, C.I., GALETTI, M., PIZO, M.A., GUIMARAES JR, P.R., \& JORDANO, P. 2007. Living in the land of ghosts: fruit traits and the importance of large mammals as seed dispersers in the Pantanal, Brazil. Seed dispersal: theory and its application in a changing world Dennis AJ, Green RJ, Schupp EW, Westcott DA, 104-123. 
DORMANN, C.F., GRUBER, B. \& FRUEND, J. 2008. Introducing the bipartite Package: Analysing Ecological Networks. R news Vol 8/2: 8 - 11 .

DOSTER, M.A. \& MICHAILIDES, T.J. 1999. Relationship between shell discoloration of pistachio nuts and incidence of fungal decay and insect infestation. Plant Dis. 83: 259-264. doi: 10.1094/PDIS.1999.83.3.259

DRAPER, D.B. \& RICHARDS, P.A. 2009. Dictionary for managing trees in urban environments. Csiro Publishing, Collingwood, Australia

ESAU, K. 1953. Plant anatomy. New York, Willey, Chapman and Hall. 735 pp.

FAN, C., TAN, L., ZHANG, C., ZHAO, X. \& VON GADOW, K. 2017. Analyzing taxonomic structures and local ecological processes in temperate forests in North Eastern China BMC Ecol (2017) 17:33 DOI 10.1186/s12898017-0143-y

FRENCH, K. 1991. Characteristics and abundance of vertebrate-dispersed fruits in temperate wet sclerophyll forest in Suotheastern Australia. Australian J. Ecol. 16: 1-13.

FLEMING, T.H. 1991. Fruiting plant-frugivore mutualism: the evolutionary theater and the ecological play. In: Plant-animal interactions: Evolutionary ecology in tropical and temperate regions. Edited by P.W. Price, M. Thomas, G.W. Fernandes and W.W. Benson. PP. 119-144. John Wiley \& Sons, Inc. New York.

FLEMING, T.H. \& KRESS, W.J. 2011. A brief history of fruits and frugivores. Acta Oecol. 37: 521-530.

FONT QUER, P. 2001. Diccionario de Botánica. 2nda ed. Ediciones Península. s.a. Barcelona, España.

FREITAS, T.G., SOUZA, C.S.D., AOKI, C. \& ARAKAKI, L.M.M. 2013. Flora of Brazilian humid Chaco: Composition and reproductive phenology. Check List 9: 973-979.

GALETTI, M., PIZO, M.A. \& MORELLATO, L.P.C. 2011. Diversity of functional traits of fleshy fruits in a species-rich Atlantic rain forest. Biota Neotrop. 11(1): http://www.biotaneotropica.org.br/v11n1/en/ abstract?article+bn02811012011.

GAUTIER-HION, A., DUPLANTIER, J.-M., QURIS, R., FEER, F., SOURD, C., DECOUX, J.-P., DUBOST, G., EMMONS, L., ERARD, C., HECKETSWEILER, P., MOUNGAZI, A., ROUSSILHON, C. \& THIOLLAY, J.-M.. 1985. Fruit characters as a basis of fruit choice and seed dispersal in a tropical forest vertebrate community. Oecologia 65:324-337.

GÓMEZ, A.J.A. 1984. Biología reproductiva comparada de cinco especies simpatridas del genero Erythroxylum en un bosque deciduo secundario en Caracas. Trabajo especial de grado, Licenciatura, Universidad Simón Bolívar, Caracas, Venezuela pp. 106.

GORDON, E. 1998. Seed characteristics of plant species from riverine wetlands in Venezuela. Aquatic Botany. 60: 417-431.

GRAAE, B.J. 2002. The role of epizoochorous seed dispersal of forest plant species in a fragmented landscape. Seed Sci. Res. 12: 113-121.

GRAY, A. 1877. Gray's lesson in botany and vegetable physiology. Ivison, Blackman, Taylor and Co., New York.

GUARALDO, A.C., BRUNA, O.B. \& PIZO, M-A. 2013. Specialized Seed Dispersal in Epiphytic Cacti and Convergence with Mistletoes. Biotropica https://doi.org/10.1111/btp.12041

GUZMÁN, M.M. 1995. Variación intraespecífica en la historia de vida y en las características reproductivas en dos poblaciones naturales de Begonia humilis Ait. (Begoniaceae) del bosque nublado de Rancho Grande, Parque nacional Henri Pittier (Edo. Aragua). Trabajo especial de grado, Licenciatura, Universidad Simón Bolívar, Caracas, Venezuela pp. 102.

HERRERA, C.M. 1982 Defense of ripe fruit from pests: its significance in relation to plant-disperser interactions; Am. Nat. 120 218-241.

HERRERA, C.M. 1984. A study of avian frugivores, bird-dispersed plants, and their intetractions in Mediterranean scrublands. Ecol. Monogr. 54: 1-23.

HERRERA, C.M. 2002a. Correlated evolution of fruit and leaf size in birddispersed plants: species-level variance in fruit traits explained a bit further? Oikos 97: 426-432.

HERRERA, C.M. 2002b. Seed dispersal by vertebrates. In: Herrera, C. M. and Pellmyr, O. (eds), Plant-animal interactions. An evolutionary approach. Wiley-Blackwell Science pp. 175-208.
HERRERA, I. \& NASSAR, J.M. 2009. Reproductive and recruitment traits as indicators of the invasive potential of Kalanchoe daigremontiana (Crassulaceae) and Stapelia gigantea (Apocynaceae) in a Neotropical arid zone. J. Arid Envir. 73: 978-986.

HEYWOOD, V.H., BRUMMITT, R.K., CULHAM, A. \& SEBERG, O. 2007. Flowering plant families of the world. Firefly Books, Ontario, Canada.

HILJE, B., CALVO-ALVARADO, J., JIMÉNEZ-RODRÍGUEZ, C. \& SÁNCHEZ-AZOFEIFA, A. 2015. Tree Species Composition, Breeding Systems, and Pollination and Dispersal Syndromes in Three Forest Successional Stages in a Tropical Dry Forest in Mesoamerica. Trop. Cons. Sci. 8: 76-94.

HOKCHE, O. \& RAMÍREZ, N. 1990. Pollination ecology of seven species of Bauhinia L. (Leguminosae: Caesalpinioideae). Annals of the Missouri Botanical Garden 77: 559-572.

HUGHES, L., DUNLOP, M., FRENCH, K., LEISHMAN, M.R., RICE, B., RODGERSON, L. \& WESTOBY, M. 1994. Predicting dispersal spectra: a minimal set of hypotheses based on plant attributes. J. Ecol. 82: 933-950.

IBARRA-MANRÍQUEZ G. \& CORNEJO-TENORIO, G. 2010. Diversidad de frutos de los árboles del bosque tropical perennifolio de México. Acta Bot. Mexicana 90: 51-104.

JANSON, C. 1983. Adaptation of fruit morphology to dispersal agents in a neotropical forest. Science 219: 187-189.

JANZEN, D.H. 1983. Physiological ecology of fruits and their seeds: physiological plant ecology. Pages 625-655 in O.L. Lange, P.S. Nobel, C.B. Osmond, and H, Ziegler, eds. Encyclopedia of plant physiology. Springer-Verlag, Berlin.

JORDANO, P. 1987. Patterns of mutualistic interactions in pollination and seed dispersal: connectance, dependence asymmetries, and coevolution. Am. Nat. (129):657-667.

JORDANO, P. 1993. Fruits and frugivory. In: M. Fenner (Ed.). Seeds: the ecology of regeneration in plant communities. Pp. 105-153. CAB International. Wallingford, England.

JORDANO, P., BASCOMPTE, J. \& OLESEN, J.M. 2003. Invariant properties in coevolutionary networks of plant-animal interactions. Ecol. Lett. 6:69-81.

JUDD, W.S., CAMPBELL, C.S., KELLOGG, E.A. \& STEVENS, P.F. 1999. Plant systematic. A phylogenetic approach. Sinauer Associates, Inc. Publishers. Sunderland, Massachusetts USA.

KELLY, D. 1985. Epiphytes and Climbers of a Jamaican Rain Forest: Vertical Distribution, Life Forms and Life Histories. J. Biog.12: 223-241.

KNIGHT, R.S. \& SIEGFRIED, R. 1983. Interrelation between type, size, and colour of fruits and dispersal in Southern Africa trees. Oecologia 56: 405-412.

KUHLMANN M. \& RIBEIRO, J.F. 2016. Evolution of seed dispersal in the Cerrado biome: ecological and phylogenetic considerations. Acta Bot. Bras. 30: 271-282.

KUIJT, J. 2001. Loranthaceae. In: Steyermark JA, Berry PE, Holst B, eds. Flora of the Venezuelan Guayana. 6: 37-59. St Louis, MO. Missouri Botanical Garden, USA.

KUIJT, J. 2005. Viscaceae. In: Steyermark JA, Berry PE, Holst B, eds. Flora of the Venezuelan Guayana. 9: 464-492. St Louis, MO. Missouri Botanical Garden, USA.

LEGENDRE, L. \& LEGENDRE, P. 1993. Numerical ecology. Amsterdam: Elsevier.

LEMUS-JIMÉNEZ, L.J. \& RAMÍREZ, N. 2002. Fenología reproductiva en tres tipos de vegetación de la planicie costera de Paraguaná, Venezuela. Acta Cient. Venez. 53: 301-313.

LIU, H., ZHANG, D., DUAN, S., WANG, X. \& SONG, M. 2014. The Relationship between Diaspore Characteristics with Phylogeny, Life History Traits, and Their Ecological Adaptation of 150 Species from the Cold Desert of Northwest China. The Scientific World Journal, Volume 2014, http:// dx.doi.org/10.1155/2014/510343

LLAMOZA-SOLÓRZANO, S. 1998. Estudio biosistematico del genero Ruellia L. (Acanthaceae) en Venezuela. Tesis doctoral, Facultad de Ciencia, Postgrado Botánica, Universidad Central de Venezuela. Caracas, Venezuela. 
LOMBARDINI, L. \& ROSSI, L. 2019. Ecophysiology of plants in dry environments. In Dryland ecohydrology (pp. 71-100). Springer, Cham.

LÓPEZ, A.J. 1981. Ritmicidad de la vegetación de una isla coralina al norte de Chichirivichi, Edo. Falcón. Tesis Licenciatura, Facultad de Ciencias, Universidad Central de Venezuela, Caracas, Venezuela.

LÓPEZ, M. \& RAMÍREZ, N. 1998. Síndromes de dispersión de diásporas de una comunidad arbustiva de la Guayana venezolana. Ecotrópicos 11: 15-32.

LÓPEZ, M. \& RAMÍREZ, N. 2013 Fenología reproductiva de un remanente de bosque deciduo secundario. Acta Biol. Venez. 33: 1-22.

LORTS, C.M., BRIGGEMAN, T. \& SANG, T. 2008. Evolution of fruit types and seed dispersal: A phylogenetic and ecological snapshot. J. Syst. Evol. 46: 396-404.

MACK, A.L. 2000. Did fleshy fruit pulp evolve as a defence against seed loss rather than as a dispersal mechanism? J. Biosci. 25: 93-97.

MADISON, M. 1977. Vascular epiphytes: their systematic occurrence and salient features. Selbyana 2: 1-13.

MEDINA, E. 1995. Diversity of life forms of higher plants in neotropical dry forests. En: Seasonal dry forests. (S.H, Bullock, A.H. Mooney, E. Medina, Eds.), Cambridge University Press, 221-242. Cambridge, England.

MEDINA, E. 2002. Tropical savannas. En: H.A. Mooney y J.G. Canadell [eds.], The Earth System: Biological and Ecological Dimensions of Global Environmental Change. Encyclopedia of Global Environmental Change. 2: 586-592. John Willey \& Sons, Ltd, Chichester.

MAMUT, J., TAN, D.-Y., BASKIN, C.C. \& BASKIN, J.M. 2014. Role of trichomes and pericarp in the seed biology of the desert annual Lachnoloma lehmannii (Brassicaceae). Ecol. Res. 29: 33-44.

MCLAREN, K. \& MCDONALD, M.A. 2005. Seasonal Patterns of Flowering and Fruiting in a Dry Tropical Forest in Jamaica1. Biotropica 37: 584-590.

MIKICH, S.B. \& SILVA, S.M. 2001. Composição florística e fenologia das espécies zoocóricas de remanescentes de florest remanescentes de floresta estacional semidecidua no centro-oeste do Paraná, Brasil. Acta Bot. Bras. 15: 89-113.

MILLER, J.S. 2005. Santalaceae. In: Steyermark JA, Berry PE, Holst B, eds. Flora of the Venezuelan Guayana 9: 44-45. St. Louis, MO. Missouri Botanical Garden, USA.

MORI, S. \& BROWN, J. 1994. Report on Wind Dispersal in Lowland Moist Forest in Central French Guiana. Brittonia, 46(2), 105-125.

NADKAMI, N.M., MEWIN, M.C. \& NIEDERT, J. 2001. Forest canopies, plant diversity. Encyclopedia of Biodiversity. 3: 27-40. Academic Press.

NAKANISHI, H. 1996. Fruit color and fruit size of bird-disseminated plants in Japan. Vegetatio 123:207-218.

NASSAR, J.M. \& RAMÍREZ, N. 2004. Reproductive biology of the melon cactus, Melocactus curvispinus (Cactaceae). P1. Syst. Evol. 248: 31-44.

NOIR, F.A.D., BRAVO, S. \& ABDALA, R. 2002. Mecanismos de dispersión de algunas especies de leñosas nativas del Chaco Occidental y Serrano. Quebracho 9: 140-150.

NYSTRAND, O. \& GRANSTRÖM, A. 1997. Post-dispersal predation on Pinus sylvestris seeds by Fringilla spp: ground substrate affects selection for seed color. Oecologia, 110: 353-359.

OLESEN, J.M., BASCOMPTE, J., DUPONT, Y.L. \& JORDANO, P. 2007. The modularity of pollination networks. P. Natl. Acad. Sci. USA 104: 19891-19896.

OLIVEIRA, P.E. 1998. Fenologia e biologia reprodutiva de espécies de cerrado; p. 169-192 In S.M. Sano and S.P. de Almeida (ed.). Cerrado, Ambiente e Flora. Planaltina: Embrapa-CPAC, 556p.

OLIVEIRA, P.E.A.M. \& A.G. MOREIRA. 1992. Anemocoria em espécies de cerrado e mata de galeria de Brasília, DF. Rev. Brasil. Bot. 15: 163-174.

OPLER, P.A., FRANKIE, G.W. \& BAKER, H.B. 1980. Comparative phenological studiesof treelet and shrub species in tropical wet and dry forests in the lowlands of Costa Rica. J. Ecol. 68: 167-188.

PARISCA L. DE \& RAMÍREZ, N. 1989. Aspectos morfoanatòmicos y ecológicos asociados a los síndromes de dispersión de un bosque ribereño del Amazonas venezolano. Acta Cient. Venez. 40: 222-231.
PATTERSON, T. B. \& GIVNISH, T.J. 2002. Phylogeny, concerted convergence, and phylogenetic niche conservatism in the core Liliales : insights from rbcL and ndhF sequence data. Evolution 56: 233-252.

PIRK, G.I. \& LOPEZ, J. 2006. Diet and seed removal rates by the harvester antsPogonomyrmex rastratus and Pogonomyrmex pronotalis in the central Monte desert, Argentina. Insect. Soc. 53: 119-125.

POSSETE, R.F.S., MIKICH, S.B., HATSCHBACH, G.G., RIBAS, O.S. \& LIEBSCH, D. 2015. Floristic composition and dispersal syndromes in Araucaria Forest remnants in the municipality of Colombo, Paraná state, Brazil. Check List 11(5): 1771, 18 October 2015 doi: http://dx.doi. org/10.15560/11.5.1771 ISSN 1809-127X

R Core Team 2015. R: A language and environment for statistical computing. R Foundation for Statistical Computing, Vienna, Austria. URL http:// www.R-project.org/.

RAMÍREZ, N. 2005. Plant sexual systems, dichogamy, and herkogamy in the Venezuelan Central Plain. Flora 200: 30-48.

RAMÍREZ N. 2009. Correlaciones entre la fenología reproductiva y variables climáticas en los Altos llanos Centrales Venezolanos. Acta Bot. Venez. 32: 333-362.

RAMÍREZ, N. \& BRITO, Y. 1987. Patrones de floración y fructificación en una comunidad pantanosa tipo morichal (Calabozo-Guàrico, Venezuela). Acta Cient. Venez. 38: 276-281.

RAMÍREZ N \& BRICEÑO, H. 2011. Reproductive phenology of 233 species from four herbaceous-shrubby communities in the Gran Sabana Plateau of Venezuela. AoB PLANTS 2011 plr014 doi:1093/aobpla/plr14

RAMÍREZ N., HOKCHE, O. \& BRICEÑO, H. 2012. Florística y grupos funcionales de plantas en comunidades herbáceo-arbustivas del sector Gran Sabana, Estado Bolívar, Venezuela. Acta Bot. Venez.35; 247-302.

RAMÍREZ, N. \& BRICEÑO, H. 2015. Tipos de rutas fotosintéticas en comunidades herbáceo-arbustivas de la Alta Guayana Venezolana. Acta Biol. Venez. 35(1) 89-123.

RAMÍREZ, N. \& HERRERA, A. 2017. Reproductive efficiency and photosynthetic pathway in seed plants. Perspect. Pl. Ecol. Evol. Syst. 24 $48-60$.

RAMÍREZ, N., GIL, C., LÓPEZ, M., HOKCHE, O. \& BRITO, Y. 1988. Caracterización florística y estructural de una comunidad arbustiva en la alta Guayana venezolana (Gran Sabana, Edo. Bolívar). Acta Cient. Venez. 38: 457-469.

RATHCKE, B.J. \& LACEY, E. 1985. Phenological Patterns of Terrestrial. Plants. Ann. Rev. Ecol. Syst. 16: 179-214.

RENOULT, J.P., VALIDO, A., JORDANO, P. \& SCHAEFER, H.M. 2014 Adaptation of flower and fruit colours to multiple, distinct mutualists. New Phytol. 201: 678-686.

RIDLEY, H.N. 1930. The dispersal of plants throughout the world. Ashford, Kent, L. Reeve \& Co., Ltd.

RUIZ-ZAPATA, T. 1994. Biología reproductiva y taxonomía del genero Cleome L. (Capparidaceae) en Venezuela. Doctoral Thesis, 299 pp. Universidad Central de Venezuela.

SCHAEFER, H.M. 2011. Why fruits go to the dark side, Acta Oecol. 37: 604-610.

SCHAEFER H.M. \& SCHMIDT, V. 2004. Detectability and content as opposing signal characteristics in fruits. Proc. R. Soc. Lond. B (Suppl.) 271: S370-S373.

SELWYN, M.A. \& PARTHASARATHY, N. 2006. Reproductive traits and phenology of plants in tropical dry evergreen forest on the Coromandel coast of India. Biod. Conserv. 15: 3207-3234

SERES, A. \& RAMÍREZ, N. 1993. Floración y Fructificación de monocotiledóneas en un bosque nublado venezolano. Rev. Biol. Trop. 41: 27-36.

SILBERBAUER-GOTTSBERGER, I. 1984. Fruit dispersal and tripanocarpy in Brasilian cerrado grasses. Pl. Syst. Evol. 147: 1-27.

SILVA, M.C.N.A. \& RODAL, M.J.N. 2009. Padrões das síndromes de dispersão de plantas em áreas com diferentes graus de pluviosidade, PE, Brasil. Acta Bot. Bras. 23: 1040-1047. 
SILVA, A.C.C., PRATA, A.P.N., MELLO, A.A. \& SANTOS, A.C.A.S. 2013. Síndromes de dispersão de Angiospermas em uma Unidade de Conservação na Caatinga, SE, Brasil. Hoehnea 40: 601-609.

SIMPSON, M.G. 2019. Plant systematics. Elselvier, Academic press.

SMITH, N., MORI, S.A., ANDERSON, A., STEVENSON, D.WM. \& HEALD, S.V. 2004. Flowering plants of the Neotropics. Princeton University Press. Princeton and Oxford.

SOBRAL, L.M. \& MACHADO, I.C.S. 2001. Fruiting Phenology and Seed Dispersal Syndromes in Caatinga, a Tropical Dry Forest in the Northeast of Brazil. J. Trop. Ecol. 17: 303-321.

SOBREVILA, C. 1978. Ecología reproductiva de un bosque montano siempreverde de Venezuela. Tesis de Licenciatura, Facultad de Ciencias, Escuela de Biología, Universidad Central de Venezuela. Caracas.

SOBREVILA, C., RAMÍREZ, N. \& DE ENRECH, N.X. 1983. Reproductive Biology of Palicourea fendleri and P. petiolaris (Rubiaceae). Heterostylous shrubs of a Tropical cloud forest in Venezuela. Biotropica 15: 161-169.

SPJUT, R.W. 1994. A systematic treatment of fruit types. Mem. New York Bot. Gard. 70: 1-182.

StatSoft, Inc. 2007. STATISTICA. (Data analysis software system). Version 8.0. www.statsoft.com.

STILES, E.W. 1982. Fruit flags: two hypotheses. Am. Nat. 120:500-509.

STRINGAM, G.R., MCGREGOR, D.I., \& PAWLOWSKI, S.H. 1974. Chemical and morphological characteristics associated with seed coat color in rapeseed. In Proceedings of the 4th International Rapeseed Congress, Giessen, Germany.

TAYLOR, D.W. \& KIRCHNER, G. 1996. The origin and evolution of the angiosperm carpel. In Flowering Plant Origin, Evolution \& Phylogeny (pp. 116-140). Springer, Boston, MA.

THOMPSON, K. 1993. Seeds: morphology and color. In: G.A.F. Hendry and J.P. Grime (eds.), Methods in Comparative Plant Ecology. Chapman and Hall, New York, 194-196.

TUGES, J.L. 1982. Fenología de un bosque deciduo tropical situado en la región de Charallave, Edo Miranda. Mimeografía. Trabajo Asenso, Facultad de Ciencias, Universidad Central de Venezuela.

VAN DER PIJL L. 1972. Principles of dispersal in higher plants, 3rd edition. Springer-Verlag, Berlin.

VIALETTE-GUIRAUD, A.C.M. \& SCUTT, C.P. 2009. Carpel evolution. Annu. Pl. Rev. Book Series 38: 1-34.

VOIGT, F.A., BLEHER, B., FIETZ, J., GANZHORN, J.U., SCHWAB, D. \& BÖHNING-GAESE, K. 2004. A comparison of morphological and chemical fruit traits between two sites with different frugivore assemblages. Oecologia 141: 94-104.

WHEELWRIGHT, N.T. \& JANSON, C.H. 1985. Colors of fruit displays of birddispersed plants in two tropical forests. Am. Nat. 126: 777-799.
WIKANDER, T. 1984. Mecanismos de dispersión de diásporas de una Selva Decidua en Venezuela. Biotropica 16: 276-283.

WILLSON, M.F., IRVINE, A.K. \& WALSH, N.G. 1989. Vertebrate dispersal syndromes in some Australian and New Zealand plant communities, with geographic comparisons. Biotropica 21:133-147.

WILLSON, M.F. \& THOMPSON, J.N. 1982. Phenology and ecology of color in bird-dispersed fruits, or why some fruits are red when they are "green". Can. J. Bot. 60:701-713.

WILLSON, M.F. \& MELAMPY, M.N. 1983. The effect of bicolored fruit displays on fruit removal by avian frugivores. Oikos 41: 27-31.

WOTTON, D.M. \& MCALPINE, K.G. 2015. Seed dispersal of fleshy-fruited environmental weeds in New Zealand. New Zealand J. Ecol. 39: 155-169.

WOTTON, D.M., DRAKE, D.R., POWLESLAND, R.G. \& LADLEY, J.J. 2016. The role of lizards as seed dispersers in New Zealand. J. Royal Soc. New Zealand 46: 40-65

XENA DE ENRECH, N., ESCALA, M., MADRID, R. \& LÓPEZ, M. 1999. Inventario florístico de angiospermas en el bosque enano del cerro Copey (Isla de Margarita, Venezuela). Ernstia 9: 51-101.

YAMAMOTO, L.F., LINOSHITA, L.S. \& MARTINS, F.R. 2007. Síndromes de polinização e de dispersão em fragmentos da Floresta Estacional Semidecídua Montana, SP, Brasil. Acta Bot. Bras. 21: 553-573.

ZIMMERMAN, J.K., WRIGHT, S.J., CALDERÓN, O., PAGAN, M.A. \& PATON, S. 2007. Flowering and fruiting phenologies of seasonal and aseasonal neotropical forests: the role of annual changes in irradiance. J. Trop. Ecol. 23: 231-251.

ZOTZ, G. \& HIETZ, P. 2001. The physiological ecology of vascular epiphytes: current knowledge, open questions. J. Exp. Bot. 52: 2067-2078.

Received: 05/06/2021

Accepted: 28/07/2021

Published online: 15/09/2021 